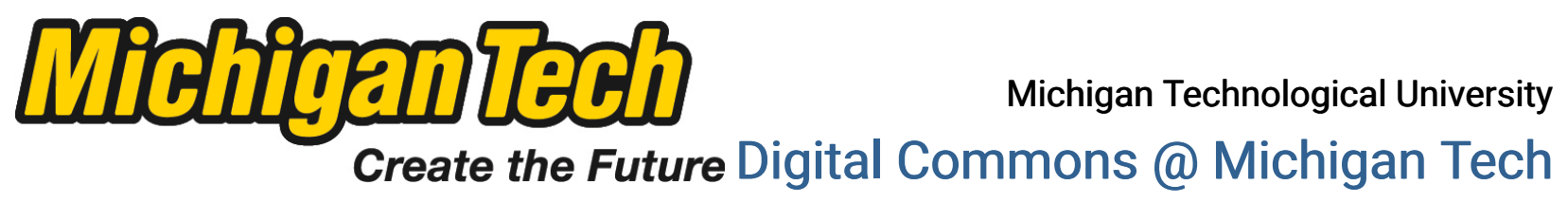

\title{
SELECTED CHEMOAUTOTROPHIC PROCESSES IN WASTEWATER TREATMENT: LOW TEMPERATURE NITRIFICATION INHIBITION BY AN AZO DYE AND BIOFILTRATION FOR ODOR CONTROL OF HYDROGEN SULFIDE
}

Ronald W. Martin Jr.

Michigan Technological University

Follow this and additional works at: https://digitalcommons.mtu.edu/etds

Part of the Civil Engineering Commons, and the Environmental Engineering Commons Copyright 2003 Ronald W. Martin Jr.

Recommended Citation

Martin, Ronald W. Jr., "SELECTED CHEMOAUTOTROPHIC PROCESSES IN WASTEWATER TREATMENT: LOW TEMPERATURE NITRIFICATION INHIBITION BY AN AZO DYE AND BIOFILTRATION FOR ODOR CONTROL OF HYDROGEN SULFIDE", Dissertation, Michigan Technological University, 2003.

https://doi.org/10.37099/mtu.dc.etds/718

Follow this and additional works at: https://digitalcommons.mtu.edu/etds

Part of the Civil Engineering Commons, and the Environmental Engineering Commons 


\title{
SELECTED CHEMOAUTOTROPHIC PROCESSES
}

\author{
IN WASTEWATER TREATMENT:
}

LOW TEMPERATURE NITRIFICATION INHIBITION

BY AN AZO DYE

AND

\section{BIOFILTRATION FOR ODOR CONTROL \\ OF HYDROGEN SULFIDE}

\author{
By \\ Ronald W. Martin, Jr. \\ A DISSERTATION \\ Submitted in Partial Fulfillment of \\ The Requirements for the Degree of \\ DOCTOR OF PHILOSOPHY \\ In Environmental Engineering
}

MICHIGAN TECHNOLOGICAL UNIVERSITY

JANUARY 2003

Copyright (C) Ronald W. Martin, Jr. 2003 
This dissertation, "Selected Chemoautotrophic Processes in Wastewater Treatment: Low Temperature Nitrification Inhibition by An Azo Dye and Biofiltration for Odor Control of Hydrogen Sulfide" is hereby approved in partial fulfillment of the requirement for the degree of DOCTOR OF PHILOSOPHY in the field of Environmental Engineering.

\section{College of Engineering}

Environmental Engineering

Michigan Technological University

Dissertation Advisor:

Dr. James R. Mihelcic

Date

Program Chair:
Dr. John C. Crittenden
Date 


\title{
SELECTED CHEMOAUTOTROPHIC PROCESSES
}

IN WASTEWATER TREATMENT:

LOW TEMPERATURE NITRIFICATION INHIBITION BY AN AZO DYE

\author{
AND \\ BIOFILTRATION FOR ODOR CONTROL OF HYDROGEN SULFIDE
}

\author{
Ronald W. Martin, Jr. \\ Department of Civil and Environmental Engineering \\ Michigan Technological University \\ 1400 Townsend Drive, Houghton, MI 49931
}

\begin{abstract}
Biochemical processes by chemoautotrophs such as nitrifiers and sulfide and iron oxidizers are used extensively in wastewater treatment. The research described in this dissertation involved the study of two selected biological processes utilized in wastewater treatment mediated by chemoautotrophic bacteria: nitrification (biological removal of ammonia and nitrogen) and hydrogen sulfide $\left(\mathrm{H}_{2} \mathrm{~S}\right)$ removal from odorous air using biofiltration.

A municipal wastewater treatment plant (WWTP) receiving industrial dyeing discharge containing the azo dye, acid black 1 (AB1) failed to meet discharge limits, especially during the winter. Dyeing discharge mixed with domestic sewage was fed to sequencing batch reactors at $22^{\circ} \mathrm{C}$ and $7^{\circ} \mathrm{C}$. Complete nitrification failure occurred at $7^{\circ} \mathrm{C}$ with more rapid nitrification failure as the dye concentration increased; slight nitrification inhibition occurred at $22^{\circ} \mathrm{C}$. Dye-bearing wastewater reduced chemical oxygen demand $(\mathrm{COD})$ removal at $7^{\circ} \mathrm{C}$ and $22^{\circ} \mathrm{C}$, increased
\end{abstract}


effluent total suspended solids (TSS) at $7^{\circ} \mathrm{C}$, and reduced activated sludge quality at $7^{\circ} \mathrm{C}$. Decreasing AB1 loading resulted in partial nitrification recovery. Eliminating the dye-bearing discharge to the full-scale WWTP led to improved performance bringing the WWTP into regulatory compliance.

Biofilter $^{\mathrm{TM}}$, a dynamic model describing the biofiltration processes for hydrogen sulfide removal from odorous air emissions, was calibrated and validated using pilot- and full-scale biofilter data. In addition, the model predicted the trend of the measured data under field conditions of changing input concentration and low effluent concentrations. The model demonstrated that increasing gas residence time and temperature and decreasing influent concentration decreases effluent concentration. Model simulations also showed that longer residence times are required to treat loading spikes.

Biofilter ${ }^{\mathrm{TM}}$ was also used in the preliminary design of a full-scale biofilter for the removal of $\mathrm{H}_{2} \mathrm{~S}$ from odorous air. Model simulations illustrated that plots of effluent concentration as a function of residence time or bed area were useful to characterize and design biofilters. Also, decreasing temperature significantly increased the effluent concentration. Model simulations showed that at a given temperature, a biofilter cannot reduce $\mathrm{H}_{2} \mathrm{~S}$ emissions below a minimum value, no matter how large the biofilter. 


\section{ACKNOWLEDGEMENTS}

I would like to acknowledge and thank the many kind individuals and helpful organizations without whose assistance this work would not have been possible. There are just too many students, faculty, staff, and friends to mention, so my apologies for those I have left out.

Foremost, I want to express my gratitude and admiration to my dissertation advisor, Professor James R. Mihelcic who has shared his expertise and knowledge and has shown immense patience and understanding. Not only do I consider Jim an esteemed professor, but also a mentor and friend. Jim had to suffer my constant lamenting on the lack of wind in Houghton.

I am also extremely grateful to the members of my committee, who, like Jim, are extremely respected and knowledgeable scientists and engineers:

- Professor John C. Crittenden has provided extensive guidance on the physical, chemical, and biological processes and has also challenged me to look beyond intuition and make decisions based on facts and scientific method; John also shares a love of outdoor activities whether in temperate Maui or the Keweenaw during the snowy, frigid winters.

- Professor C. Robert Baillod who is extremely knowledgeable in wastewater treatment; Bob is probably one of the few people I know who is more interested in sewage and its treatment than me.

- Professor Donald R. Lueking provided a wealth of microbiological expertise and was able to tie this in with the physical and chemical processes; Don has also been friendly and encouraging with his easy-going personality. 
Without the encouragement, guidance, and support of my committee, I could not have completed this dissertation.

In addition to the intellectual support, this project also required substantial financial assistance. Funding for this research was provided by the following:

- The U.S. Department of Education Graduate Assistantship in Areas of National Need (GAANN) Ph.D. fellowship;

- Michigan Technological University Graduate School Ph.D. fellowship;

- National Center for Clean Industrial and Treatment Technologies (CenCITT, Michigan Technological University, Houghton); CenCITT is partially supported by a grant from the U.S. Environmental Protection Agency;

- Donohue and Associates; and

- Cedar Rapids Water Pollution Control Facilities.

Several additional people also provided invaluable assistance in this research. Dr. Christopher L. Wojick helped to design and construct the laboratory SBRs. Sue E. Bunzendahl assisted with collection and analysis of samples (and kept me entertained with expressions like “Do What?"). David L. Perram provided advice and assistance setting up and carrying out analyses. Professor David Hand provided essential use of his lab and equipment (and goodnaturedly gave me a hard time). Dr. Hebi Li provided extensive help with biofilter modeling and explaining biofilter processes. Dave Hokansen provided expertise on biofiltration and the biological, physical, and chemical processes and crucial hardware and software support. Karl Peterson and Larry Sutter performed extensive mineralogical analyses of the lava rock. Mike LaBeau and Professor Susan T. Bagley provided the microscopic analysis and photos of the 
activated sludge. Professor Marttin T. Auer provided the photospectrometer for measuring dye concentrations. Professor Noel Urban and Professor Judith Perlinger provided useful technical advice. Professor Richard Honrath and Professor David Watkins provided advice on modeling and statistics. Ken Palosari and the rest of the Computing Systems group provided invaluable hardware and software help.

Keith Anderson (Western Lake Superior Sanitary District) provided useful advice based on his extensive experience with compost biofilters. I thoroughly enjoyed working with Keith and hanging out with him in Duluth. Chris Hatch and Pat Ball also provided invaluable advice and assistance at the Cedar Rapids Water Pollution Control Facilities. Ken Sedmak of Donohue and Associates provided help with the nitrification inhibition study.

Denise Heikinen proof-read several journal submissions and provided additional assistance. Shelle Sandell and Corrine Leppen both provided extensive help with various administrative tasks. Thanks for all the candy Corrine! Dr. Marilyn Vogler Urion and Mina Grudnoski provided help with Graduate School requirements.

In addition to the people who helped with the research, administration, and funding, I would like to thank my family and friends who have provided encouragement, support, and enjoyable distractions and who have also helped to shape my life. These people have been helping me to define myself in childhood and they keep helping me as I continue to grow. Although this world has many difficult journeys and sometimes almost unbearable circumstances, I feel it is a magical gift to be a part of it. I thank my parents Ronald Martin, Sr. and Beverly C. Martin for bringing me into this world and helping to guide me through it. My brothers Michael G. Martin and Matthew C. Martin have also been pillars in our family. I have also been blessed to be able to spend time with my wonderful grandparents William and Alice 
Craig and my late grandmother Sonny Martin. I have too many cousins, aunts, and uncles to name them all, but special mention goes to my Aunt Pat \& Uncle Joe Bassett who gave me a fascinating Christmas present when I was probably not yet 10 years old: a junior chemistry set.

I was also incredibly lucky to have met Jamie Bacon who brought passion and desire into my life and challenged me to look at things beyond my scientific instinct. Jamie is an incredibly beautiful spirit who cares about life, relationships and the world and helped re-ignite that passion in me.

I have also made a few close and valuable friends while here at MTU. I have spent a lot of time climbing rock and ice with Pete Rynes despite our first epic misadventure climbing ice in the Cliffs. Not only does Pete fix incredible meals for his entertaining and irreverent dinner parties, he is a close friend who made life in Houghton much more fun and exciting.

Mike Dziobak is one of the most intense and dedicated athletes that I have had the pleasure (and pain) to ice climb and ski with. Mike is also a rock climber, kayaker, and windsurfer and has traveled to some incredibly beautiful places. I could always count on Don Salo to go out windsurfing the few times it is windy on Superior. I'll never forget the first time we sailed together in late November and had to swim back in the frigid Superior after the wind died. However, Don and I prefer sailing in "The Gorge" (the Columbia River Gorge).

I also had many fun days climbing and hanging out with my friends Brian Rajdl, Nick Chope, Tony Jenkins, Joe Fass, Rose Cory, Nicole Bloom, and Jessica Bibbee. Even though we never climbed, skied, or windsurfed together, I had many exciting adventures with my friends Katherine Strojny, Chris Edlin, Ellie Bunzendahl, and Katie \& Anna "Banana" Rajdl.

I was initially drawn to MTU by the Peace Corps Master's International program but somehow ended up doing a traditional PhD. Still, Professor Blair Orr always included me in the 
Peace Corps Master's International "meetings" at the Ambassador and provided exciting stories of development work in Africa. Jim Mihelcic, Tom Van Dam, and the many Peace Corps Master's International Students and returned volunteers (special mention to former office-mate and micro lab partner Andrea Telmo, Mali RPCV and to Michelle Anderson, Nigeria RPCV who published several of my articles in Keweenaw Today).

I was also able to placate my travel addiction by hanging out with many international students and partying with the International Club. Although there are too many international students to mention, Mustafa Ishaq, Ingvild Stromsholm, Wellesley Pereira, Alexei Dorofeev, and Kateryna Lapina deserve special mention.

I also want to thank Valerie Pegg for selecting me to be on the Cultural Enrichment Committee, which provided the privilege of meeting and dining with and hanging out with very interesting speakers and entertainers. The Cultural Enrichment Committee brought invaluable cultural enrichment to the UP.

I have also met many fellow travelers and foreign friends (Bobo Vucen, Maja Lalic Kovacevic, Sue Parker, Herta Eckert, Bojan Boskovic, Vlada Elezovic \& Tanja Zlatanovic, Selim \& Filoreta Shala, Angelina Avramovic and her family, Markus Wieshofer, Walter Schachinger, George Ewins, and Rene Weirmans) in my work and travels. Fellow windsurfers (Frank \& Niranda Schafuss, Royn Bartholdi, Wolfgang Kratzer, Carl Martineau \& Susan Krieger, Temira Wagonfeld, Krishna Chand, Randy \& Chantel, Dayna, Dave, Dan, Mitch, and from the very early days Curt Claflin and Bill Bakert) and climbing \& skiing (Keith Phelps, Tom Martin, and Martin Hackworth) buddies have also helped me to keep my sanity and perspective in this crazy world. 
I also want to mention friends from my undergraduate days at Ohio State who I still keep in touch with (Dan Minnich, Urban Seger DVM, Paul Dreyfuss MD, Harold Hom, and Jeff Travers MD), from high school who I much less frequently hear from (Doug Brimmer, Kelly Cartwright, and Scott Lawhead) and friends from the formative years of youth who I rarely hear from but still think of (Nick Orzechowski, Mark Burchette, and Jimmy Bassett MD).

Education has always been a very important part of my life. Both of my parents and my grandfather (William Craig) were high school teachers and through them I developed a strong desire for learning. My co-advisors at the University of Kentucky, Professor Dibakar Bhattacharyya (DB) and Professor Kimberly Anderson provided a very firm foundation for my continued education. DB was (and I assume still is) an enthusiastic teacher who made learning fun and interesting. I was also lucky to have had exceptional teachers who sparked my interest in learning that led me to become an engineer. In high school, Richard Brunt (Biology), the late Robert "slide-rule" Bean (Chemistry), Robert Gardner (Physics \& Astronomy), the late Al Mosak (Math), and Paulette Dewey (English) all provided essential skills for my higher education, but they also made learning interesting. Before high school, Mr. Fisher (junior high school science), Mrs. Endsley (grade school science), and Mrs. Bowles (grade school math) helped to guide me onto this life path.

My parents' careers in physical education and love of coaching also provided the basis for my active lifestyle. My wrestling coach, Ray Steely instilled the idea of doing your best (giving 110\%) and being persistent. Ray's wife, JackieSteely, assistant coach Richard Guinta, and athletic directors Dick Wagner and the late Jim Vitale also played a crucial role in my athletic and personal development. 
I also want to thank several people who have helped me to learn and succeed in my profession. I learned so much about wastewater treatment and consulting engineering from Felix Sampayo and Dail Hollopeter at Jones \& Henry Engineers (Toledo, OH) and from Walt Meyer at West Yost Associates (Eugene, OR). Gene Ballentine, Curt Claflin, Jim Mrvos, and Pat Quinn all helped me in my first engineering job at IBM (Lexington, KY).

Through all of these activities, teachings, and relationships I have developed a love for this world and life and a desire to protect it and keep it healthy. I have chosen a profession in environmental engineering because of this ideal. I believe that much of the MTU faculty and staff share this view. The philosophy behind this degree and dissertation is not just to obtain knowledge for knowledge's sake, but the hope and desire to set this learning into action by applying it to try and solve some of the world's problems.

As John* explains, for an engineering solution to work, the engineer must look into the theory and science to come up with a technical solution; but, to make that solution useful, the engineer must translate the solution into practice and must also consider the effect on the entire ecosystem and must take into account the social dimensions of the solution.

This lesson can be carried even further in how we, as the race of humankind decide to live our lives. We (especially engineers) can often look at and grasp the physical and scientific. But, we must look beyond and look not just outside but also inside. We cannot rely merely on science, observation, and knowledge. I doubt science will be able to answer all our questions (what is infinite time and space? Is there such a thing as fate and is our life pre-determined? What comes after this life if anything? Is there some greater plan to this life and the universe?) If you are looking for the answers to these questions, you won't find them here. But realizing that we are not just physical beings, and that in addition to body and mind, that there is a part of 
us much less easily grasped and defined and sometimes referred to as the "spirit" or the "human spirit"...well, then you are aware and heading in the right direction.

Finally, I would like to dedicate this dissertation to mother earth, to all those who have helped me as I wander this beautiful planet, and especially to the people striving and sacrificing for a better world not just through sanitation and a clean environment but also through human rights, freedom, and peace. Those struggles make mine seem insignificant and bearable.

*John C. Crittenden (2002) Engineering the Quality of Life. Clean Techn. Environ. Policy, 4, 6-7. 


\section{TABLE OF CONTENTS}

$\begin{array}{lll}\text { ABSTRACT } & \text { i }\end{array}$

ACKNOWLEDGEMENTS iii

TABLE OF CONTENTS $\quad$ xi

LIST OF TABLES X xvi

LIST OF FIGURES $\quad$ xviii

CHAPTER 1: INTRODUCTION AND BACKGROUND $\quad$ 1-1

CHAPTER 2: NITRIFICATION INHIBITION AT LOW TEMPERATURE BY THE AZO DYE ACID BLACK 1

$\begin{array}{lr}2.1 \text { INTRODUCTION 2-2 } & 2-2\end{array}$

2.2 MATERIALS AND METHODS 2-7

$\begin{array}{ll}\text { 2.2.1 Experimental Equipment } & 2-7\end{array}$

$\begin{array}{lr}\text { 2.2.2 Experimental Conditions } & 2-10\end{array}$

$\begin{array}{lr}\text { 2.2.3 Method of Analyses } & \text { 2-13 }\end{array}$

2.3 RESULTS AND DISCUSSIONS $2-16$

$\begin{array}{ll}\text { 2.3.1 Analyses of Nitrogen Species } & \text { 2-16 }\end{array}$

2.3.2 Ammonia Removal 2-16

$\begin{array}{lr}\text { 2.3.3 Additional Performance Characteristics } & \text { 2-19 }\end{array}$

$\begin{array}{lr}\text { 2.3.4 Potential Solutions } & 2-25\end{array}$ 
\begin{tabular}{l}
2.4 CONCLUSIONS \\
\hline
\end{tabular}

$\begin{array}{lr}2.5 \text { ACKNOWLEDGEMENTS } & \text { 2-27 }\end{array}$

$\begin{array}{lr}\text { 2.5.1 Credits } & 2-27\end{array}$

$\begin{array}{lr}\text { 2.5.2 Authors } & 2-27\end{array}$

2.6 REFERENCES 2-27

CHAPTER 3: OPTIMIZATION OF BIOFILTRATION FOR ODOR CONTROL: MODEL CALIBRATION, VALIDATION, AND APPLICATIONS

3.1 INTRODUCTION 3-2

3.2 MATERIALS AND METHODS 3-3

3.2.1 Background $\quad 3-3$

3.2.2 Biofilters and Packing Medium 3-5

3.2.3 $\mathrm{H}_{2} \mathrm{~S}$ Data Collection $\quad 3-6$

3.2.4 Additional Data Collection $\quad 3-8$

3.2.5 Calibration and Validation Periods $\quad 3-9$

3.2.6 Data Input for the Model 3-9

3.2.7 Model Calibration and Validation 3-10

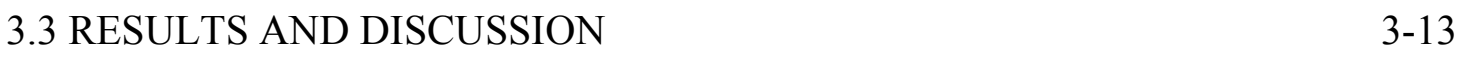

$\begin{array}{lr}\text { 3.3.1 Model Calibration } & 3-13\end{array}$

$\begin{array}{lr}\text { 3.3.2 Model Validation } & 3-15\end{array}$

3.3.3 Model Applications $\quad$ 3-19

3.3.3.1 Effect of Residence Time on $\mathrm{H}_{2} \mathrm{~S}$ Removal 3-20

3.3.3.2 Effect of the Influent Concentration on $\mathrm{H}_{2} \mathrm{~S}$ Removal 3-21 


\section{CHAPTER 4: A BIOFILTER DESIGN AND PERFORMANCE CHARACTERIZATION STRATEGY FOR THE CONTROL OF ODOROUS HYDROGEN SULFIDE}

4.1 INTRODUCTION 4-1

4.1.1 Odor Control Using Biofiltration 4-1

4.1.2 Design and Optimization of Biofilters for Control of Odorous $\mathrm{H}_{2} \mathrm{~S}$

4.1.3 Model Description and Application 4-5

4.2 METHODOLOGY 4-5

4.2.1 Biofilter Microbiology, Packing Material, and Bed Depth 4-6

4.2.2 Design Criteria

4.2.3 Model Simulations

4.3 RESULTS AND DISCUSSION 4-11

4.3.1 Removal Capacity as a Function of Loading 4-11

4.3.2 Removal Efficiency as a Function of Loading 4-16

4.3.3 Removal Efficiency as a Function of Residence Time 4-18

4.3.4 Effluent $\mathrm{H}_{2} \mathrm{~S}$ Concentration as a Function of Residence Time 4-21 
4.3.5 Minimum Effluent $\mathrm{H}_{2} \mathrm{~S}$ Concentration as a Function of Temperature

4.3.6 Effect of Flow, Bed Area and Depth, and Particle Sizes

4-24

4.3.7 Effluent $\mathrm{H}_{2} \mathrm{~S}$ Concentration as a Function of Bed Area

4-26

4.3.8 Dynamic Response to Feed Concentration Step Increase

$4-28$

4.3.9 Biofilter Construction and Operation

4-30

4.3.10 Biofilter Configuration

4-32

4.4 CONCLUSIONS

4-34

4.5 REFERENCES

4-35

CHAPTER 5: CONCLUSIONS AND RECCOMENDATIONS

5-1

5.1 CONCLUSIONS

$5-1$

5.2 RECOMMENDATIONS

$5-4$

\section{APPENDIX A: BIOFILTER ${ }^{\text {TM }}$ CALIBRATION AND VALIDATION ACCOUNTING FOR VARIABLE FLOW AND DEPTH PROFILE OF HYDROGEN SULFIDE CONCENTRATION}

A.1 INTRODUCTION

A.2 METHODOLOGY

A-2

A.3 RESULTS AND DISCUSSION

A-6

A.4 CONCLUSIONS

A-18

A.5 REFERENCES

A-19

APPENDIX B: UNCERTAINTY IN MODEL SIMULATED EFFLUENT HYDROGEN SULFIDE CONCENTRATION

B-1 
APPENDIX C: COMPARISON OF VARIOUS BIOFILTER DESIGN AND

PERFORMANCE CHARACTERIZATION PLOTS

C-1 


\section{LIST OF TABLES}

Table 2.1 Feed Concentrations, Temperatures, and Solids Retention Time for the Eight Bench-Scale Sequencing Batch Reactors.

Table 2.2 SBR Cycle Times with Description of Each Step in the Cycle.

Table 2.3 Description of Analytical Methods Used and Frequency of Sampling.

Table 2.4 Concentration of Acid Black 1 in Dye-bearing Wastewater Feed During Study.

Table 2.5 Concentration of Acid Black 1 in Dye-bearing Wastewater Feed During Study.

Table 2.6 Tabulation of Cold Room $\left(7^{\circ} \mathrm{C}\right)$ Effluent TSS Concentration.

Table 2.7 Tabulation of Oxygen Uptake Measurements of Activated Sludge.

Table 3.1 Values of Parameters Used for Model Calibration and Validation.

Table 3.2 Values of Biokinetic Parameters for Thiobacillus Reported in Recent Literature.

Table 4.1 Summary of Biofilter Design Criteria.

Table A.1 Air Flow Measurements for the Calibration and Validation Periods.

Table A.2 Comparison of Original and Corrected Model Input Values.

Table A.3 Range of Model Parameters Used in Determining the Re-Calibration and Re-Validation Solutions and Original Parameter Values used by Martin et al. (2002).

Table A.4: Comparison of Objective Function and Sum of Absolute Value of Residuals for Re-calibration, Re-validation, and Original Solution. 
Table A.5: Model Parameters from Re-calibration Solutions.

Table A.6: Model Parameters from Re-validation Solutions.

Table C.1: Appendix C Plots and Corresponding Plots in Chapter 4.

C-2 


\section{LIST OF FIGURES}

Figure 2.1 Chemical Structure of the Disodium Salt of the Azo Dye Acid Black 1.

Figure 2.2 Laboratory Set-up of Room Temperature SBRs: SBR5 to SBR8;

Refrigerator for Feed and Decant Storage; Emergency Overflow Buckets.

Figure 2.3 Concentration Profile of Various Nitrogen Species in Cold Room $\left(7^{\circ} \mathrm{C}\right)$ and at Room Temperature $\left(22^{\circ} \mathrm{C}\right)$ at Stable Reactor Conditions.

Figure 2.4 Cold Room $\left(7^{\circ} \mathrm{C}\right)$ Ammonia Removal During Experimental Period.

Figure 2.5 Room Temperature $\left(22^{\circ} \mathrm{C}\right)$ Ammonia Removal During Experimental Period.

Figure 2.6 Organic Nitrogen Removal in Cold Room $\left(7^{\circ} \mathrm{C}\right)$ and Room Temperature $\left(22^{\circ} \mathrm{C}\right)$ during Stable Reactor Conditions.

Figure 2.7 Cold Room $\left(7^{\circ} \mathrm{C}\right)$ COD Removal During Experimental Period.

Figure 2.8 (a) Activated Sludge from Sequencing Batch Reactor 1 Fed $0 \%(\mathrm{v} / \mathrm{v})$ Dye-bearing Wastewater at $7^{\circ} \mathrm{C}$; (b) Sequencing Batch Reactor 4 Fed 9\% (v/v) Dye-bearing Wastewater at $7^{\circ} \mathrm{C}$.

Figure 3.1 Process Flow Diagram for Pilot-Scale Biofilter and Full-Scale Biofilter 1 at Cedar Rapids WPCF.

Figure 3.2 Model Simulated Effluent Concentration Compared to the Measured Effluent for the Calibration Period.

Figure 3.3 Model Simulated Effluent Concentration Compared to the Measured Effluent for the Pilot-Scale Validation Period.

Figure 3.4 Model Simulated Effluent Concentration Compared to the Measured Effluent for the Full-Scale Validation Period Assuming $1.0 \%$ of the Bed Is Inactive.

Figure 3.5 Model Simulations Showing Effluent Concentration as a 
Function of Residence Time.

Figure 3.6 Model Simulations Showing Minimum Residence Time Required to Achieve a Treatment Objective of $0.5 \mathrm{ppm}_{\mathrm{v}}$ as a Function of Influent Concentration.

Figure 3.7 Model Simulations Showing Start-Up Period for Various

Temperatures.

Figure 3.8 Biofilter ${ }^{\mathrm{TM}}$ Simulations Showing the Effect of Influent Concentration Step Changes on Biofilter Performance Based on the Full-scale Cedar Rapids WPCF Biofilter Bed Size.

Figure 4.1 Model Simulated Sulfide Elimination as a Function of Sulfide Loading for Various Influent Hydrogen Sulfide Concentrations.

Figure 4.2 Model Simulated Average Active Biomass Concentration in the Biofilm as a Function of Sulfide Loading for Various Influent Hydrogen Sulfide Concentrations and Bed Locations.

Figure 4.3 Model Simulated Hydrogen Sulfide Removal as a Function of Sulfide Loading for Various Influent Hydrogen Sulfide Concentrations.

Figure 4.4 Model Simulated Hydrogen Sulfide Removal as a Function of Residence Time for Various Influent Hydrogen Sulfide Concentrations.

Figure 4.5 Model Simulated Effluent Hydrogen Sulfide Concentration as a Function of Residence Time for Various Influent Hydrogen Sulfide Concentrations.

Figure 4.6 Theoretical Steady-state Minimum Effluent Hydrogen Sulfide Concentration as a Function of Temperature.

Figure 4.7 Model Simulated Effluent Hydrogen Sulfide Concentration as a Function of Residence Time for Various Lava Rock Sizes.

Figure 4.8 Model Simulated Effluent Hydrogen Sulfide Concentration as A Function of Biofilter Bed Area for Various Operational Conditions.

Figure 4.9 Model Simulated Effluent Hydrogen Sulfide Concentration as a Function of Elapsed Time After Start-up: Response to a Spike in Feed Hydrogen Sulfide Concentration for Various Operational Conditions. 
Figure A.1 Comparison of the Output from Various Model Calibration

Conditions to the Measured Data for Pilot Scale Biofilter:

Effluent Hydrogen Sulfide Concentration as a Function of Time.

Figure A.2 Comparison of the Output from Various Model Validation

Conditions to the Measured Data for Pilot Scale Biofilter:

Effluent Hydrogen Sulfide Concentration as a Function of Time.

Figure A.3 Comparison of Re-calibration Solutions: Effluent Hydrogen

Sulfide Concentration as a Function of Time.

Figure A.4 Comparison of Re-validation Solutions: Effluent Hydrogen

Sulfide Concentration as a Function of Time.

Figure A.5 Comparison of Original and Re-calibration Solutions to Measured Data: for Bed Profile of Hydrogen Sulfide Concentration as a Function of Distance from Influent.

Figure B.1 Biofilter Temperature as a Function of Time at Various Biofilter Bed Locations During Calibration Period.

Figure B.2 Model Simulated Effluent $\mathrm{H}_{2} \mathrm{~S}$ Concentration for Solution 1

Re-calibration Showing Temperature Uncertainty Approximation.

Figure B.3 Model Simulated Effluent $\mathrm{H}_{2} \mathrm{~S}$ Concentration for Solution 1

Re-validation Showing Temperature Uncertainty Approximation.

Figure B.4 Minimum and Maximum Air Feed Velocity as a Function of Time During Calibration Period for Various Anemometers.

Figure B.5 Model Simulated Effluent $\mathrm{H}_{2} \mathrm{~S}$ Concentration for Solution 1 Re-calibration Showing Flow Uncertainty Approximation.

Figure B.6 Model Simulated Effluent $\mathrm{H}_{2} \mathrm{~S}$ Concentration for Solution 1 Re-validation Showing Flow Uncertainty Estimate.

Figure C.1 Model Simulated Sulfide Elimination as a Function of Sulfide Loading for Various Model Input Parameters.

Figure C.2 Model Simulated Hydrogen Sulfide Removal as a Function of Sulfide Loading for Various Model Input Parameters. 
Figure C.3 Model Simulated Hydrogen Sulfide Removal as a Function of Residence Time for Various Model Input Parameters.

Figure C.4 Model Simulated Effluent Hydrogen Sulfide Concentration as a Function of Residence Time for Various Model Input Parameters.

Figure C.5 Theoretical Minimum Steady-state Effluent Hydrogen Sulfide Concentration as a Function of Temperature for Various Model Input Parameters. 


\section{CHAPTER 1}

\section{INTRODUCTION AND BACKGROUND}

Wastewater treatment has been used for many years to protect human health and to also prevent the degradation of the environment. Initially, wastewater treatment simply consisted of primary settling to remove settleable solids; biological treatment was eventually added to remove organics. Today a modern municipal wastewater treatment plant (WWTP) may utilize a variety of complex physicochemical (e.g. settling, filtration, disinfection with ultraviolet light, disinfection with chlorine, and polymer addition) and biochemical (e.g. activated sludge and digestion) processes to control a wide variety of municipal and industrial pollutants.

Biochemical processes are used extensively in wastewater treatment and may include many types of microorganisms such as protozoa (e.g., in activated sludge), bacteria (e.g., in activated sludge and digester sludge), and algae (e.g., in oxidation ponds). Removal of organic matter in a WWTP is carried out by heterotrophic bacteria, which, by definition, utilize an organic carbon source for cell synthesis. Autotrophic bacteria, however, obtain carbon for cell synthesis from carbon dioxide $\left(\mathrm{CO}_{2}\right)$. The bacteria that remove ammonia $\left(\mathrm{NH}_{3}\right)$ from wastewater, referred to as nitrifying bacteria or nitrifiers, are one type of autotroph commonly found at a wastewater treatment plant. Nitrifiers are also classified as chemotrophs because they derive their energy from the oxidation of chemical compounds, as opposed to deriving energy from light for photosynthesis (phototrophs).

Chemoautotrophs (also called chemolithotrophs) such as nitrifiers and sulfide oxidizers, and iron oxidizers are essential in the natural cycling of nutrients and can utilize reduced inorganic compounds that are derived from anthropogenic sources (e.g., mines, agriculture, and 
combustion) as well as natural sources (e.g., volcanic, atmospheric, soil, fresh and sea water sediments, and the stomachs of ruminants) (Kuenen and Bos, 1989). Chemoautotrophs also play an important role in wastewater treatment. For example, in the first step of biological nitrogen removal, nitrifying bacteria oxidize $\mathrm{NH}_{3}$ to a less toxic forms of nitrogen (i.e., nitrate). In addition, sulfur-oxidizing bacteria that are present in biofilters are used to remove odor-causing air emissions that contain hydrogen sulfide $\left(\mathrm{H}_{2} \mathrm{~S}\right)$. Because they typically obtain less energy from oxidation of inorganic compounds compared to heterotrophs obtaining energy from oxidation of organic compounds, chemoautotrophs have much lower growth rates and yields (WEF, 1994); therefore, they are more prone to upsets and recover less rapidly when exposed to an inhibitory compound.

Nitrification is important during wastewater treatment because failure to remove ammonia can result in oxygen depletion, fish kills, and eutrophication of receiving waters. Nitrification in a WWTP requires a longer solids retention time than that for heterotrophs because nitrifying bacteria have a low growth rate and cell yield which makes them more susceptible to being washed out of the aeration tank. Nitrifying bacteria are also sensitive to environmental conditions such as temperature, $\mathrm{pH}$, and dissolved oxygen concentration. The growth and activity of nitrifiers can also be inhibited by a wide variety of organic and inorganic chemicals, including metals and organic compounds.

Another class of pollutants that have become an increasing concern for WWTPs is odorous air emissions caused by gases that contain chemicals such as $\mathrm{H}_{2} \mathrm{~S}$. In addition to causing aesthetic problems for individuals who reside near treatment plants and pump stations, $\mathrm{H}_{2} \mathrm{~S}$ can also adversely effect human health and corrode plant equipment. Biofiltration is one method that has been used to control $\mathrm{H}_{2} \mathrm{~S}$ emissions. It consists of passing odorous air through a 
packing material that contains attached chemoautotrophic sulfur-oxidizing bacteria that oxidize the $\mathrm{H}_{2} \mathrm{~S}$ to sulfuric acid. However, until Biofilter ${ }^{\mathrm{TM}}$, no rigorous mathematical model had been developed for the design and optimization of biofilters used for odor control (Li et al., 2002).

The research described in this dissertation applies theoretical and experimental methods to help provide solutions to potential and actual problems experienced in wastewater treatment processes. It involves the study of two selected biological processes utilized in wastewater treatment that are mediated by chemoautotrophic bacteria: nitrification inhibition and $\mathrm{H}_{2} \mathrm{~S}$ removal using biofiltration. These studies include laboratory, pilot-scale, and full-scale studies and include actual design and operational applications. Accordingly, the objectives of this dissertation are to:

1. utilize a laboratory scale pilot study to determine if an industrial chemical (i.e., the azo dye acid black 1) inhibited nitrification at low temperatures at a WWTP that employed sequencing batch reactors to treat a combination of municipal and industrial wastewater;

2. use pilot-study and full-scale biofilter data to calibrate and validate a mathematical model that describes the biofiltration process used for treating odorous air emissions that contain $\mathrm{H}_{2} \mathrm{~S}$; and,

3. apply the biofiltration model for the design of a biofiltration unit that is to remove $\mathrm{H}_{2} \mathrm{~S}$ from odorous air. 
Objective one of this dissertation is addressed in Chapter 2 of this dissertation. Chapter 2 details Nitrification Inhibition at Low Temperature by the Azo Dye Acid Black 1 that has been presented at the "Research Symposium: Factors Affecting Biological Nutrient Removal" (Session 23, October 1, 2002) of the 2002 Water Environment Federation Technical Exhibition and Conference (WEFTEC 2002, Chicago, IL). This presentation was published in the conference proceedings and, after modification, was submitted to and is currently under review by Water Environment Research. Chapter 2 is a more comprehensive presentation of the study detailed in the original published article (due to space limitations for the original article).

Objective two is addressed in Chapter 3 of this dissertation. Chapter 3 consists of the article Optimization of Biofiltration for Odor Control: Model Calibration, Validation, and Applications that has been published in Water Environment Research (Martin et al., 74(1):17-27, 2002). In this study, the pilot-scale study was designed and data were collected and analyzed by this author. Other individuals assisted the author in the final model calibration and validation. Additional calibration and validation solutions performed by the author have been added in Appendix A in order to assist in understanding the biofiltration process and also to provide possible alternative operation conditions.

Chapter 4 will address the third objective of this dissertation. It presents the results of applying the biofiltration model (incorporated into a user-friendly software called Biofilter ${ }^{\mathrm{TM}}$ ) for the preliminary design and operation of a full-scale biofiltration unit designed to remove $\mathrm{H}_{2} \mathrm{~S}$ from odorous air. This is the first reported use of a rigorous modeling approach for the design of a biofilter used to treat $\mathrm{H}_{2} \mathrm{~S}$. This chapter will be submitted, at a later date, to an applied engineering journal (e.g. Chemical Engineering Progress, Water Environment and Technology, Environmental Engineering Science, or Journal of the Air and Waste Management). 
Because each of the main chapters consists of a journal article submission, the abstract, introduction, material and methods, results and discussion, conclusions, acknowledgements, and references sections will be included in each individual chapter. However, a final Chapter (Chapter 5) will summarize the conclusions and recommendations of this work. Additional detailed records and calculations are included in the Appendix.

\section{REFERENCES}

Kuenen, J.G., and Bos, P. (1989) Habitats and Ecological Niches of Chemolitho(auto)trophic Bacteria. Autotrophic Bacteria, Ed., Schlegel, H.G., and Bowien, B., Springer Berlig, Berlin, pp. $53-80$.

Li, H.; Crittenden, JC; Mihelcic, JR; and Hautakangas, H. (2002) Optimization of Biofiltration for Odor Control: Model Development and Parameter Sensitivity. Water Environ. Res., 72(1), 516. 


\title{
CHAPTER 2
}

\section{NITRIFICATION INHIBITION AT LOW TEMPERATURE BY THE AZO DYE ACID BLACK 1 *}

\begin{abstract}
A municipal wastewater treatment plant (WWTP) receiving industrial dyeing discharge containing acid black 1 (AB1) failed to meet discharge limits, especially during the winter. Dyeing discharge was mixed with domestic sewage in volumetric ratios reflecting the range received by the WWTP and fed to sequencing batch reactors at $22^{\circ} \mathrm{C}$ and $7^{\circ} \mathrm{C}$. Analysis of the various nitrogen species revealed complete nitrification failure at $7^{\circ} \mathrm{C}$ with more rapid nitrification failure as the dye concentration increased; slight nitrification inhibition occurred at $22^{\circ} \mathrm{C}$. Dye-bearing wastewater also reduced COD removal at $7^{\circ} \mathrm{C}$ and $22^{\circ} \mathrm{C}$ and increased effluent TSS at $7^{\circ} \mathrm{C}$. Activated sludge quality at $7^{\circ} \mathrm{C}$ deteriorated, as indicated by excessive foaming and the presence of filamentous bacteria and by decreased oxygen uptake. Decreasing AB1 loading resulted in partial nitrification recovery. Eliminating the dye-bearing discharge to the full-scale WWTP led to improved performance bringing the WWTP into compliance with discharge limits.
\end{abstract}

KEYWORDS: azo dye, nitrification, inhibition, temperature, wastewater, activated sludge, sequencing batch reactor.

\footnotetext{
* The work presented in this chapter was published in the Proc. Water. Environ. Fed. 75th Annu. Conf. Exposition [CD-ROM], Chicago, IL and was submitted to Water Environment Research on June 20, 2002. This chapter is a revised and more detailed presentation of the study.
} 


\subsection{INTRODUCTION}

Nitrogen removal is a crucial stage of wastewater treatment because the high oxygen demand of ammonia $\left(\mathrm{NH}_{3}\right)$ can deplete oxygen in receiving waters, the un-ionized species of $\mathrm{NH}_{3}$ is toxic to fish, and $\mathrm{NH}_{3}$ is a nutrient that promotes algae and aquatic plant growth that may lead to eutrophication. $\mathrm{NH}_{3}$ also reduces chlorination efficiency and can corrode copper pipes (Bitton, 1999). Although physical and chemical methods such as air stripping, breakpoint chlorination, and ion exchange can be used for $\mathrm{NH}_{3}$ removal (Tchobanoglous and Burton, 1991), municipal wastewater treatment plants (WWTP) usually employ nitrification/denitrification for biological nitrogen removal.

Nitrification, the bacterial conversion of ammonium $\left(\mathrm{NH}_{4}{ }^{+}\right)$to nitrate $\left(\mathrm{NO}_{3}{ }^{-}\right)$, is carried out in two steps (Bitton, 1999). In the first step, bacteria (e.g. Nitrosomonas in activated sludge) convert ammonium to nitrite $\left(\mathrm{NO}_{2}^{-}\right)$:

$$
\mathrm{NH}_{4}{ }^{+}+1.5 \mathrm{O}_{2} \rightarrow \mathrm{NO}_{2}^{-}+2 \mathrm{H}^{+}+\mathrm{H}_{2} \mathrm{O}+2.75 \mathrm{~kJ} / \text { gmole } \mathrm{NH}_{4}{ }^{+} \text {. }
$$

In the second step, bacteria (e.g. Nitrobacter in activated sludge) convert nitrite to nitrate:

$$
\mathrm{NO}_{2}^{-}+0.5 \mathrm{O}_{2} \rightarrow \mathrm{NO}_{3}^{-}+75 \mathrm{~kJ} / \text { gmole } \mathrm{NO}_{2}^{-} \text {. }
$$

Because nitrifying bacteria grow slowly and are sensitive to environmental conditions, care must be taken to prevent nitrification failure. Nitrifying bacteria require sufficient dissolved oxygen (DO) levels. Concentrations below $2 \mathrm{mg} \mathrm{DO} / \mathrm{L}$ significantly reduce nitrification while concentrations below $0.5 \mathrm{mg} \mathrm{DO} / \mathrm{L}$ drastically reduce nitrification (Grady et al., 1999). The growth and activity of nitrifiers is also greatly influenced by temperature, although "quantification of this effect has been difficult" (Tchobanoglous and Burton, 1991). Bitton (1999) suggests an optimum temperature of $30^{\circ} \mathrm{C}$ for nitrification with growth in the range of $8^{\circ} \mathrm{C}$ to $35^{\circ} \mathrm{C}$ and an optimum $\mathrm{pH}$ range of 7.2 to 8.5 with failure below $\mathrm{pH}$ 6.0. Also, due to acid 
production during nitrification, sufficient alkalinity must be present to prevent the $\mathrm{pH}$ from dropping below inhibitory levels.

The growth and activity of nitrifiers can be inhibited by a wide variety of organic and inorganic chemicals. For example, high concentrations of $\mathrm{NH}_{3}$ and nitrous acid can inhibit nitrification (Tchobanoglous and Burton, 1991). In addition, nitrifiers are sensitive to inhibition by cyanide, thiourea, halogen-substituted phenolic compounds, halogenated solvents, phenol, cresol, anilines, silver, mercury, nickel, chromium, copper, cadmium, lead, and zinc (Bitton, 1999). Wastewater from dyeing operations, which may be discharged to a WWTP, may also inhibit the activated sludge process, and the chemoautotrophic nitrifying bacteria are particularly susceptible to inhibition (Vandevivere et al., 1998).

The textile industry discharges large quantities of wastewater, and azo dyes make up $60 \%$ to $70 \%$ of all textile dyes produced (Vandevivere et al., 1998). Azo dyes contain between one and three azo bonds (-N=N-) linking phenyl or naphthyl radicals, which are often substituted with various combinations of the following functional groups: amino $\left(-\mathrm{NH}_{2}\right)$, chloro (-Cl), hydroxyl (-OH), methyl $\left(-\mathrm{CH}_{3}\right)$, nitro $\left(-\mathrm{NO}_{2}\right)$, and the sodium salt of sulfonic acid $\left(-\mathrm{SO}_{3} \mathrm{Na}\right)$ (Shaul et al., 1988). The azo dye studied in this project, acid black 1 (AB1) (CAS No. 00106448-8), has the empirical formula $\mathrm{C}_{22} \mathrm{H}_{14} \mathrm{~N}_{6} \mathrm{O}_{9} \mathrm{~S}_{2}{ }^{(-2)}$ and the chemical structure is shown in Figure 2.1. Azo dyes have widespread industrial applications in textiles, pharmaceuticals, foods, cosmetics, printing, and optical recording and data storage media (He and Bishop, 1994; RazoFlores, et al., 1997; and Åstrand et al., 2000). Furthermore, some azo dyes, their precursors, and degradation products are carcinogens, suspected carcinogens, or mutagens (Shaul et al., 1986; Harmer and Bishop, 1992; Razo-Flores et al., 1997; and Vandevivere et al., 1998). 


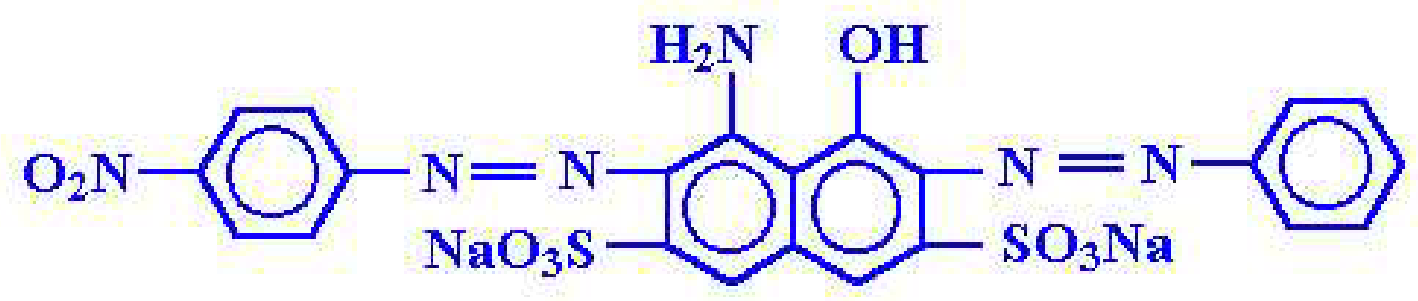

Figure 2.1 - Chemical Structure of the Disodium Salt of the Azo Dye Acid Black 1.

Several physical methods have been used to treat wastewater from dyeing operations, including electrolysis, foam flotation, filtration, coagulation and flocculation, oxidation (with ozone or hydrogen peroxide and ferrous iron), sorption (with activated carbon, clay, or biomass), and photocatalysis (Vandevivere et al., 1998). McCurdy et al. (1992) found that pre-treating a mixture of azo dyes with reducing agents for color removal inhibited activated sludge microorganisms. However, adding an oxidizing agent between reduction pretreatment and biological treatment resulted in an effluent more amenable to the biological treatment.

Shaul et al. (1988) investigated the fate of 18 soluble azo dyes in a pilot scale activated sludge process, focusing on sorption onto the activated sludge and biodegradation because chemical transformation, photodegradation, and air stripping were determined to be insignificant in the overall fate of the dyes. Of these 18 azo dyes, 11 passed through essentially untreated, 4 sorbed onto the activated sludge without biodegradation, and 3 were biodegraded.

There is a great deal of literature (O’Neill et al., 2000a; Razo-Flores et al., 1997; Zaoyan et al., 1992; and Brown and Hamburg, 1987) on anaerobic biodegradation of azo dyes in which color is removed by cleavage of the azo bond(s). Because potentially toxic or inhibitory aromatic amines from anaerobic biodegradation can often be treated aerobically (O’Neill et al., 2000a, and Zaoyan et al., 1992), azo dyes may be more thoroughly treated by anaerobic treatment followed by aerobic treatment. 
Not all azo dyes require anaerobic treatment followed by aerobic treatment. Nigam et al. (1996) studied aerobic isolates that showed growth on media containing various azo dyes but with no decolorization of the azo dyes; however, several azo dyes were $100 \%$ decolorized under anaerobic conditions by mixed cultures that could only achieve decolorization working as a consortium. Razo-Flores et al. (1997) found that the azo dye azodisalicylate acid (ADS) could be anaerobically treated (up to $95 \%$ removal) with ADS serving as the sole carbon and energy source with methane and $\mathrm{NH}_{3}$ the mineralization end products. He and Bishop (1994) found that the mono-azo dye acid orange 7 (AO7) could be aerobically biodegraded and Furukawa et al. (1999) cultivated a denitrifying sludge that removed azo dyes (including AB1) when irradiated under anoxic conditions.

Although there is extensive literature on the treatment of azo dyes and inhibition of the activated sludge process by azo dyes, we found no prior literature reporting inhibition of activated sludge, including nitrification inhibition, by the azo dye AB1. Brown et al. (1981) reported that out of 202 dyes studied, 18 exhibited greater than $50 \%$ respiration inhibition of activated sludge at a dye concentration less than $100 \mathrm{mg} / \mathrm{L}$. Burg and Charest (1980) reported 6 of 23 azo dyes studied showed greater than $10 \%$ oxygen uptake inhibition of activated sludge at a dye concentration of up to $25 \mathrm{mg} / \mathrm{L}$. In both of these studies, AB1 was not found to inhibit activated sludge. Also, Shaul et al. (1988) observed that between $96 \%$ and $100 \%$ of AB1 (at concentrations of $1 \mathrm{mg} \mathrm{AB} 1 / \mathrm{L}$ and $5 \mathrm{mg} \mathrm{AB} 1 / \mathrm{L}$ ) passed through an activated sludge process without significant biodegradation or sorption onto the activated sludge. Burg and Charest (1980) report an $\mathrm{LC}_{50}$ (the concentration at which $50 \%$ of the experimental animals survive) of $180 \mathrm{mg} \mathrm{AB} 1 / \mathrm{L}$ for fathead minnows (Pimephales promelas) exposed to AB1 for 96 hours. 
Previous research has also shown that azo dyes, other than $\mathrm{AB} 1$, inhibited the activated sludge process. Tong and Young (1974) determined that wastewater from an azo dye manufacturer inhibited activated sludge nitrification resulting in effluent with higher $\mathrm{NH}_{3}$ and lower $\mathrm{NO}_{2}^{-}$concentrations. He and Bishop (1994) reported that AO7 inhibited biofilm nitrification (at less than 5mg/L), due to decreased nitrifier activity. Harmer and Bishop (1992) showed that AO7 competitively inhibited chemical oxygen demand (COD) removal in suspended phase but not in a biofilm and indicated inhibition by AO7 of both steps of nitrification. Fu et al. (1994) found that AO7 at a concentration of $40 \mathrm{mg}$ AO7/L inhibited respiration in a biofilm removed from a reactor previously fed the azo dye acid red 14 (AR14) while AR14 (10 mg AR14/L) inhibited biofilm respiration but had no effect on COD removal. A WWTP receiving a dye-bearing wastewater failed to meet its discharge limits, especially during the winter months, when the influent wastewater temperature dropped to as low as $7^{\circ} \mathrm{C}$. The WWTP, employing two sequencing batch reactors (SBRs) in parallel (average flow of $167 \mathrm{~m}^{3} /$ day), experienced poor removal of 5-day biochemical oxygen demand $\left(\mathrm{BOD}_{5}\right)$, total suspended solids (TSS), and - especially $-\mathrm{NH}_{3}$. Due to the purple-black color visible in both the raw sewage fed to the WWTP and in the treated effluent, an industrial discharge from a dyeing operation was the suspected inhibitor. The objective of this study was to determine if the dye-bearing wastewater inhibited the activated sludge process. The study was carried out at typical summer and winter temperatures and at several different dye concentrations.

The industry, operating 8 hours per day, 5 days per week, discharged non-uniform volumes and concentrations of industrial wastewater resulting from periodic dumps (containing a higher dye concentration) as well as continuous rinsing operations (containing a lower dye concentration). The discharge from the dyeing operation made up approximately $3 \%$ of the 
average volumetric flow to the WWTP and, during peak operations, up to a maximum $8 \%$ of the volumetric flow to the WWTP. The dyeing operation discharged a mixture of azo dyes (including AO7, direct black P, acid yellow 23, and acid yellow 250), whitener (methyl diethyl amino coumarin), citric acid, sodium chloride, sodium hydroxide, and hydrogen peroxide but AB1 made up more than $99.7 \%$ (by weight) of the total dyes and whitener used in the industrial dyeing operation. Further investigation is required to verify that $\mathrm{AB} 1$ is the sole inhibitor and preclude the possibility that the small amount of the other chemicals is contributing to the inhibition.

\subsection{MATERIALS AND METHODS}

A laboratory-scale experiment was devised to determine if the dyeing operation discharge caused the nitrification inhibition at the WWTP. The dyeing operation discharge was mixed with raw domestic sewage in volumetric ratios spanning the range received by the WWTP and fed to bench-scale SBRs simulating winter and summer conditions. The solids retention time (SRT) was maintained above 30 days, by controlling sludge wasting, to prevent washing out the nitrifiers, and the experiment was conducted over a sufficient period of time to allow for the SBRs to achieve stability and to show any inhibition.

2.2.1 Experimental Equipment. Each laboratory scale SBR consisted of a 4-inch inside diameter (ID) by 30-inch high transparent polyvinyl chloride cylindrical reactor. A set of four SBRs was operated at room temperature while an identical set of four "cold room" SBRs was operated in a Russel Technical Products (Holland, MI) (model WMB-450-3S) environmental control chamber. Two stands were constructed from Globe Strut ${ }^{\circledR}$ aluminum framing (Pinckneyville, IL) (1-5/8 inch channels) to mount each set of four SBRs and the required 
mixers, airflow meters, aeration solenoid valves, and effluent decant tubes. A Chrontrol ${ }^{\circledR}$ (San Diego, CA) (XT Tabletop, 4-circuit, 40 program) timer was used to switch (on and off) feed and decant pump drives, mixers, and aeration solenoid valves at the set cycle times. The room temperature SBRs are shown in Figure 2.2 with the environmental control chamber in the background.

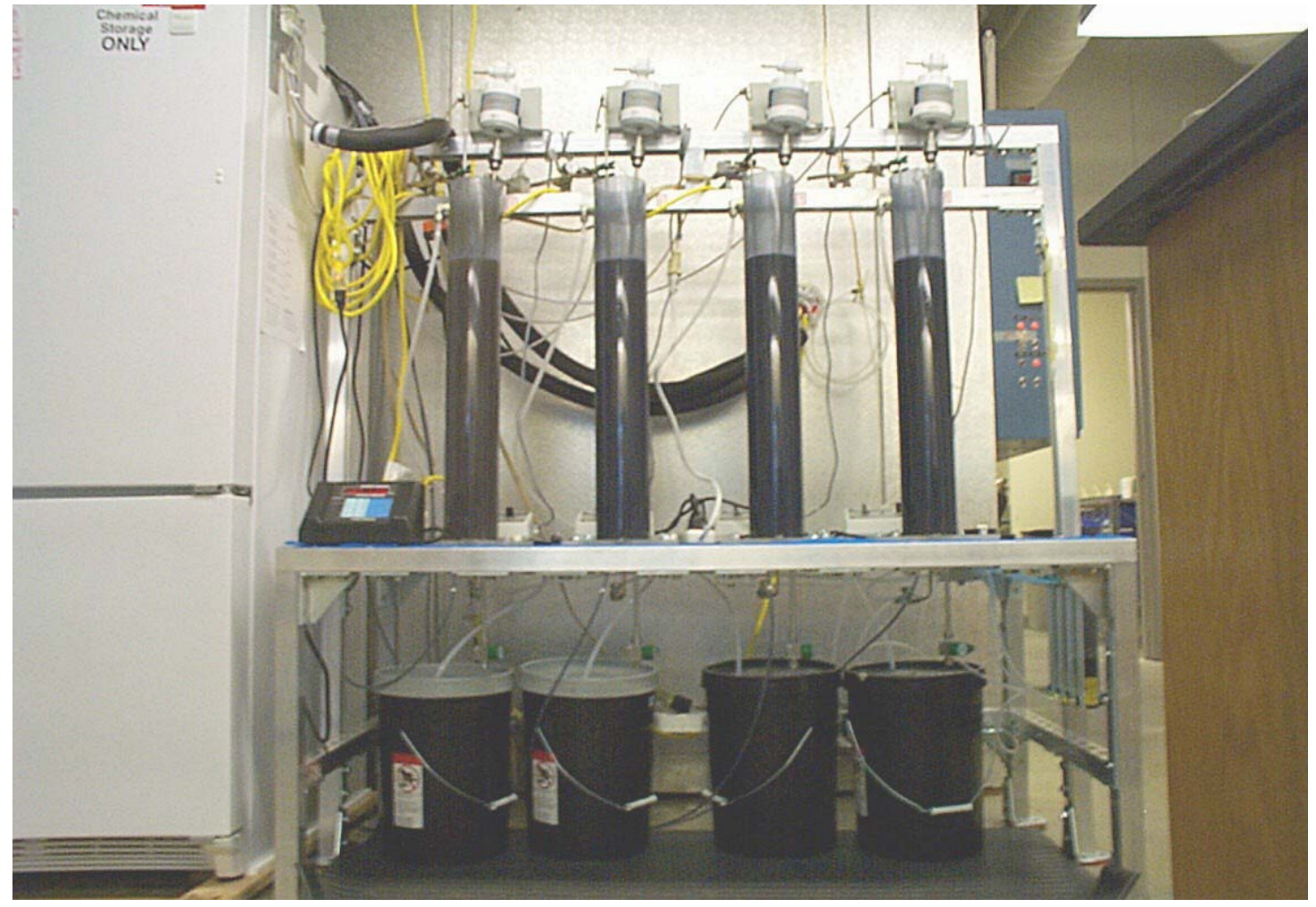

Figure 2.2 - Laboratory Set-up of Room Temperature SBRs: SBR5 to SBR8 (Left to Right); Refrigerator for Feed and Decant Storage (Left); Emergency Overflow Buckets (Bottom).

Feed was introduced into the bottom of each SBR with a Cole-Parmer ${ }^{\circledR}$ (Vernon Hills, IL) (Masterflex ${ }^{\circledast}$ L/S Series) multi-channel peristaltic pumping system consisting of a single variable speed drive (Masterflex ${ }^{\circledR}$ L/S Series, 1-1000 RPM, 115V) fitted with a pump head (Masterflex ${ }^{\circledR}$ L/S Series, 8-channel 4-roller) housing eight cartridge pump heads (Masterflex ${ }^{\circledR} \mathrm{L} / \mathrm{S}$ Series, 
small). These pumps delivered feed at equal rates (within $\pm 4 \%$ of the average) to each SBR. Similarly, an identical Cole-Parmer ${ }^{\circledR}$ (Masterflex ${ }^{\circledR}$ L/S Series) multi-channel peristaltic pumping system was used to decant effluent from the SBRs at equal rates (within $\pm 4 \%$ of the average). The liquid volume in the SBR was measured as a function of depth using a transparent ruler mounted on the front each of the reactors and calibrated using tap water at the appropriate operating temperature. Feed and decant flow rates were determined by measuring the depth change per unit time. Feed was pumped from 15-liter high-density polyethylene (HDPE) carboys and decant was collected in 9-liter HDPE carboys. Feed to and decant from the SBRs were pumped through $1 / 8$-inch polyethylene tubing. Tubing to and from the cold room was insulated with 1-inch diameter foam tubing and both feed and decant containers were stored in a Whirlpool ${ }^{\circledast}$ (Benton Harbor, MI) refrigerator-freezer (model EB22DKXFW01) maintained at $4^{\circ} \mathrm{C}$.

A Cole-Parmer ${ }^{\circledR}\left(\right.$ Stir-Pak $^{\circledR}$ dual shaft, $1 / 25$ horsepower, variable speed) mixer with two (1.5-inch diameter) propellers was mounted on top of each SBR with the shaft offset at an angle of approximately 4 degrees. The mixer speeds were set at $815 \pm 15 \mathrm{rpm}$. Compressed air was fed through a filtered regulator and switched on and off with a 2-way Skinner Valve (New Britain, CT) solenoid (7000 Series, 1/4-inch NPT). The air was fed through a 7/8-inch diameter spherical Fisher Scientific (Pittsburgh, PA) fused alumina diffuser stone (model 11-139B, 60 micrometer average pore size), one each mounted in the bottom of each SBR. Each SBR air line had a dedicated flowmeter (Cole Parmer ${ }^{\circledR} 150 \mathrm{~mm}$, aluminum frame, $46 \mathrm{~mL} / \mathrm{min}$ maximum flow rate) to measure the airflow rate and a Nupro ${ }^{\circledR}$ (Willoughby, OH) lift check valve (50 Series with 1/4inch Swagelock ${ }^{\circledR}$ fitting) to prevent wastewater from backfilling the air line. 
A 3/8-inch ID stainless steel sludge wasting tube was used to drain the waste activated sludge. It was fitted with a plug valve $\left(\right.$ Nupro $^{\circledR}$ P6T Series, stainless steel, with 3/8-inch Swagelock $^{\circledR}$ fittings) mounted into the bottom of the SBR with a bore-through fitting to allow for easy adjustment of the tube depth. The top of the tube was set at a depth of $7.4 \mathrm{~cm}$ from the bottom of the SBR.

2.2.2 Experimental Conditions. The study was conducted in eight SBRs: one set of four SBRs, receiving $0 \%, 3 \%, 6 \%$, and $9 \%(\mathrm{v} / \mathrm{v})$ feed concentrations of dyeing operation discharge was operated at room temperature and another set receiving the same four concentrations was operated in the cold room. The cold room SBRs were maintained at $7 \pm 2{ }^{\circ} \mathrm{C}$ (including a defrost cycle of 20 minutes three times per day) and the room temperature SBRs at $25 \pm 5^{\circ} \mathrm{C}$ for the duration of the experiment and $22 \pm 2{ }^{\circ} \mathrm{C}$ during stable reactor conditions. Table 2.1 summarizes the experimental conditions for the eight SBRs.

Table 2.1: Feed Concentrations, Temperatures, and Solids Retention Time for the Eight Bench-Scale Sequencing Batch Reactors.

Cold Room SBRs: (Temperature $=7 \pm 2^{\circ} \mathrm{C}$; Effective SRT $=28.1 \pm 0.5$ days)

SBR 1: 0\% (v/v) Dyeing operation discharge (control)

SBR 2: 3\% (v/v) Dyeing operation discharge

SBR 3: $6 \%(\mathrm{v} / \mathrm{v})$ Dyeing operation discharge

SBR 4: 9\% (v/v) Dyeing operation discharge

$\underline{\text { Room Temperature SBRs }}$ (Temperature $=22 \pm 2^{\circ} \mathrm{C}$; Effective SRT $=36.3 \pm 1.5$ days)

SBR 5: $0 \%(\mathrm{v} / \mathrm{v})$ Dyeing operation discharge (control)

SBR 6: 3\% (v/v) Dyeing operation discharge

SBR 7: $6 \%(\mathrm{v} / \mathrm{v})$ Dyeing operation discharge

SBR 8: 9\% (v/v) Dyeing operation discharge

Reactors were seeded with sludge from a WWTP that nitrified but did not receive any dye-bearing wastewater. No sludge was wasted during the first week of operation, to allow the 
nitrifying bacteria to grow without being washed out and to acclimate to the dye. Sludge was then wasted in small volumes at least once per day and often several times per day to reduce shock to the biomass caused by intermittent wasting of large volumes of activated sludge. The SRT was controlled by sludge wasting and was determined using the following equation:

$$
\mathrm{SRT}=(\mathrm{V})(\mathrm{MLSS}) /\left[\left(\mathrm{F}_{\mathrm{w}}\right)\left(\mathrm{TSS}_{\mathrm{w}}\right)+\left(\mathrm{F}_{\mathrm{e}}\right)\left(\mathrm{TSS}_{\mathrm{e}}\right)\right]
$$

Where

$$
\begin{aligned}
& \text { MLSS = mixed liquor suspended solids concentration in SBR, } \\
& \mathrm{V}=\text { volume of liquid in the SBR, } \\
& \mathrm{F}_{\mathrm{w}}=\text { volumetric rate of sludge wasting, } \\
& \mathrm{TSS}_{\mathrm{w}}=\text { total suspended solids concentration of wasted sludge, } \\
& \mathrm{F}_{\mathrm{e}}=\text { volumetric rate of effluent decant, and } \\
& \mathrm{TSS}_{\mathrm{e}}=\text { total suspended solids concentration in the effluent decant. }
\end{aligned}
$$

Although the suspended solids in the decant effluent can often be neglected when determining the SRT, it is included in this expression due to the low concentration of solids in the wasted sludge and the high concentration of solids in the effluent decant. The hydraulic retention time (HRT) was determined from the following equation:

$$
\mathrm{HRT}=\mathrm{V} / \mathrm{F}
$$

where $\mathrm{F}$ is the volumetric flow rate of the feed to the SBR. Because the biochemical reactions are assumed to occur only during the fill and reaction steps in the cycle (not during the settling, decant, and idle steps), Grady et al. (1999) define the effective SRT (ESRT) and the effective HRT (EHRT) as follows:

$$
\begin{aligned}
& \text { ESRT }=(z)(\operatorname{SRT}) \text {, and } \\
& \text { EHRT }=(z)(H R T),
\end{aligned}
$$


where $\mathrm{z}$ is the fraction of the total cycle in which filling and reaction occurs; $\mathrm{z}$ was equal to 0.667 in this study. The SBRs in this study were operated at an ESRT of $28.1 \pm 0.5$ days in the cold room and $36.3 \pm 1.5$ days at room temperature to provide sufficient time to maintain growth of the nitrifying bacteria. The EHRT was $3.13 \pm 0.06$ days in the cold room and $3.38 \pm 0.10$ days at room temperature.

Raw domestic sewage containing no dyeing operation discharge was collected from a lift station feeding the WWTP. Discharge from the dyeing operation was collected from the facility and included industrial wastewater from both the dumps and continuous rinse operations (combined in a 1:1 ratio). The raw domestic sewage and dyeing operation discharge were collected every four to thirteen days, transported, and mixed as needed to provide the dyebearing wastewater feed for the SBRs; all were stored at $4^{\circ} \mathrm{C}$ from collection until use.

The cycle time of each SBR was set at 6 hours and included a wastewater feed of 3 hours ( $50 \%$ of the total cycle period) to match the average operating conditions of the WWTP. Grady et al. (1999) suggests an aerobic fraction (AF) of between 0.5 and 0.8 to achieve optimum $\mathrm{NH}_{3}$ and $\mathrm{NO}_{3}{ }^{-}$removal, where $\mathrm{AF}$ equals "the fraction of the fill plus react period that is aerobic". The AF in this study was 0.625 . Table 2.2 lists the length and description of each step within the cycle.

The experiment was conducted for 62 days (approximately 2 SRTs), sufficient time to allow all SBRs to achieve stability and show nitrification inhibition. Stability was verified by examining effluent and mixed liquor concentrations to see if they approached asymptotic values. All SBRs exhibited stable reactor conditions within 52 days of start-up. 


\section{Table 2.2: SBR Cycle Times with Description of Each Step in the Cycle.}

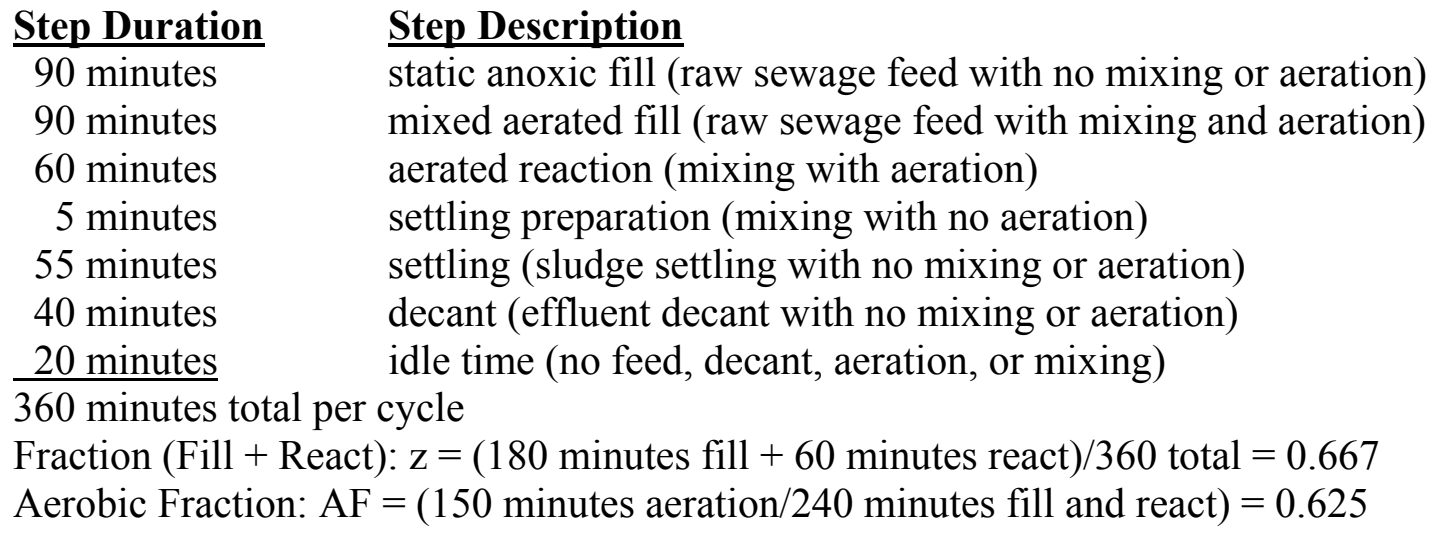

2.2.3 Method of Analyses. Feed and effluent were analyzed for $\mathrm{NH}_{3}, \mathrm{NO}_{3}{ }^{-}, \mathrm{NO}_{2}{ }^{-}$, total Kjeldahl nitrogen (TKN), TSS, COD, $\mathrm{BOD}_{5}, \mathrm{pH}$, alkalinity, and volatile suspended solids (VSS). All nitrogen-containing compounds are expressed in terms of quantity of nitrogen (e.g. $\mathrm{NH}_{3}-\mathrm{N}$ signifies the amount of nitrogen present as $\mathrm{NH}_{3}$ ). Because COD analyses provide more reliable, reproducible, and faster results than $\mathrm{BOD}_{5}$ analyses, $\mathrm{COD}$ analyses were performed routinely. Mixed liquor and settled sludge were analyzed for MLSS, mixed liquor volatile suspended solids (MLVSS), and DO. All samples were stored at $4{ }^{\circ} \mathrm{C}$ and, except for TKN, none were preserved with sulfuric acid. Samples were analyzed within four days except for $\mathrm{NH}_{3}$ (analyzed within 24 hours), MLVSS and MLSS (analyzed within 24 hours), and TKN (analyzed within 3 weeks). The analytical methods, frequency, and a brief description of each sample analysis are summarized in Table 2.3. Temperatures were measured using thermometers submerged in the room temperature SBRs and thermocouples submerged in the cold room SBRs and were recorded weekly and during the oxygen uptake measurements.

Feed samples were collected for analysis after mixing. Decant tanks were emptied when they became full and when newly mixed feed was added to the feed tanks; thus, SBR effluent samples were composite samples of effluent decant for the entire period of decant collection 
(between 4 and 8 days). Mixed liquor samples were collected by first scrubbing the walls of the SBR with a nylon test tube brush to remove attached solids, purging the sludge wasting tube, pouring the purge back into the SBR, and drawing a sample during aerated mixing.

Table 2.3: Description of Analytical Methods Used and Frequency of Sampling.

\begin{tabular}{llll} 
Analysis & Frequency & Description & Method [1] \\
\cline { 2 - 2 } & Weekly & Colorimetric, Digested & EPA 351.2 \\
$\mathrm{NO}_{3}{ }^{-}, \mathrm{NO}_{2}{ }^{-}$ & Weekly & Ion chromatography (IC) & SM 4100-B \\
$\mathrm{NH}_{3}-\mathrm{N}$ & Weekly & Ammonia probe & SM 4500-NH $F$ \\
$\mathrm{TSS}_{3}, \mathrm{MLSS}$ & Weekly & Filter, dry, weigh & SM 2540-D \\
$\mathrm{BOD}_{5}$ & Monthly & Incubation bottle & SM 5210-B \\
$\mathrm{COD}$ & Weekly & Open Reflux and titration & SM 5220-B \\
$\mathrm{DO}$ & Monthly & Oxygen probe & SM 4500-OG \\
pH & Weekly & pH probe & SM 4500- $H^{+} B$ \\
Alkalinity & Monthly & Titration & SM 2320-B \\
VSS, MLVSS & Weekly & Filter, ignite, weigh & SM 2540-E
\end{tabular}

[1] EPA: Environmental Protection Agency (1983); SM: Standard Methods for the Examination of Water and Wastewater (American Public Health Association et al., 1992).

Results from analysis of samples of the discharge collected from the dyeing operation and of raw domestic sewage collected from the lift station are shown in Table 2.4. The dyeing operation discharge and raw domestic sewage have similar characteristics, except for COD which is more than three times higher in the dyeing operation discharge. These samples were mixed to provide the dye-bearing wastewater feed to the SBRs during stable reactor conditions.

The concentration of $\mathrm{AB} 1$ in the feed to the SBRs throughout the duration of the study varied due to the varying $\mathrm{AB} 1$ concentration in the samples collected from the industrial dyeing operation. The $\mathrm{AB} 1$ concentration in the samples from the industrial discharge was determined by measuring the peak absorbance (at $620 \mathrm{~nm}$ ) using a Perkin Elmer (Lambda 2 Model) UV/VIS Spectrometer. The AB1 concentrations over the course of the experiment are listed in Table 2.5. 
Table 2.4: Concentration of Acid Black 1 in Dye-bearing Wastewater Feed During Study.

\begin{tabular}{|c|c|c|}
\hline $\begin{array}{l}\text { Wastewater } \\
\text { Characteristic }\end{array}$ & $\begin{array}{c}\text { Dyeing Operation } \\
\text { Discharge } \\
\text { (grab sample) } \\
\end{array}$ & $\begin{array}{l}\text { Raw Domestic Sewage } \\
\text { (lift station grab sample) }\end{array}$ \\
\hline $\mathrm{AB1}(\mathrm{mg} / \mathrm{L})$ & 810 & $\mathbf{0}$ \\
\hline BOD $_{5}(\mathrm{mg} / \mathrm{L})$ & 87 & 100 \\
\hline $\mathrm{COD}(\mathrm{mg} / \mathrm{L})$ & 1,200 & 370 \\
\hline TKN (mg/L) & 57 & 45 \\
\hline TSS (mg/L) & 110 & 150 \\
\hline VSS/TSS (\%) & $85 \%$ & $81 \%$ \\
\hline
\end{tabular}

Table 2.5: Concentration of Acid Black 1 in Dye-bearing Wastewater Feed During Study.

\begin{tabular}{|c|c|c|c|c|c|}
\cline { 3 - 6 } \multicolumn{2}{c|}{} & \multicolumn{4}{c|}{$\begin{array}{c}\text { Acid Black 1 Dye Concentration } \\
\text { in Reactor Feed (mg AB1/L) }\end{array}$} \\
\hline $\begin{array}{c}\text { SBR } \\
\text { Number }\end{array}$ & $\begin{array}{c}\text { Dyeing } \\
\text { Discharge } \\
\text { (v/v) }\end{array}$ & $\begin{array}{c}18-24 \text { days } \\
\text { after } \\
\text { start-up }\end{array}$ & $\begin{array}{c}24-30 \text { days } \\
\text { after } \\
\text { start-up }\end{array}$ & $\begin{array}{c}30-52 \text { days } \\
\text { after } \\
\text { start-up }\end{array}$ & $\begin{array}{c}52-59 \text { days } \\
\text { after } \\
\text { start-up }\end{array}$ \\
\hline $1 \& 5$ & $0 \%$ (controls) & 0 & 0 & 0 & 0 \\
\hline $2 \& 6$ & $3 \%$ & 15 & 9.3 & 24 & 5.8 \\
\hline $3 \& 7$ & $6 \%$ & 29 & 19 & 49 & 12 \\
\hline $4 \& 8$ & $9 \%$ & 44 & 28 & 73 & 18 \\
\hline
\end{tabular}

Oxygen uptake was determined by measuring the DO concentration in a sample of mixed liquor withdrawn at the end of the aerated mixing step and was determined at the same temperature as the SBR. The sample was initially shaken in a closed bottle with a large headspace bringing the DO concentration near saturation and then the change in DO concentration was plotted over time. For exogenous samples, raw sewage containing no AB1 was added to the mixed liquor (raw sewage comprised $5 \%$ of the total volume) prior to shaking; endogenous samples were not fed raw sewage. 


\subsection{RESULTS AND DISCUSSIONS}

The performance of the reactors was examined over the duration of the study including at stable reactor conditions attained at the end of the study (1.9 ESRTs). Although the concentration varied throughout the study, during stable reactor conditions, the $3 \%, 6 \%$, and $9 \%$ ( $\mathrm{v} / \mathrm{v}$ ) dyeing discharge in the feed corresponded to $24 \mathrm{mg} \mathrm{AB1/L}, 49 \mathrm{mg} \mathrm{AB} 1 / \mathrm{L}$, and $73 \mathrm{mg}$ $\mathrm{AB} 1 / \mathrm{L}$, respectively.

2.3.1 Analyses of Nitrogen Species. Figure 2.3 shows the concentrations of the various forms of nitrogen $\left(\mathrm{NH}_{3}-\mathrm{N}, \mathrm{NO}_{3}{ }^{-}-\mathrm{N}\right.$, and $\left.\mathrm{TKN}\right)$ in the feed and effluent during stable reactor conditions as a function of $\mathrm{AB} 1$ concentration. Figure 2.3 indicates that there is no $\mathrm{NH}_{3}$ removal and no substantial $\mathrm{NO}_{3}{ }^{-}$formation in the cold room SBRs fed dyeing operation discharge compared to $99.9 \% \mathrm{NH}_{3}$ removal, corresponding to an effluent $\mathrm{NH}_{3}$ concentration of $0.04 \mathrm{mg} / \mathrm{L}$ $\mathrm{NH}_{3}-\mathrm{N}$, achieved in the cold room control (fed no dye). The absence of $\mathrm{NO}_{2}^{-}$(data not shown) indicates that the first nitrification step (conversion of $\mathrm{NH}_{4}{ }^{+}$to $\mathrm{NO}_{2}{ }^{-}$by Nitrosomonas) is inhibited by the dye-bearing wastewater. This agrees with the observation by Bitton (1999) that many inhibitors are more toxic to Nitrosomonas than to Nitrobacter. He and Bishop (1994) found that "ammonium oxidizers were more sensitive to $\mathrm{AO} 7$ than $\mathrm{NO}_{2}{ }^{\text {" }}$ oxidizers".

2.3.2 Ammonia Removal. Figure 2.3 shows that all room temperature SBRs achieved greater than $96 \%$ ammonia removal. Figure 2.3 and TKN data (not shown) also indicate that there was less than $20 \%$ denitrification in any of the reactors and this was probably due to the high DO concentrations. Measuring the DO concentration throughout each step for an entire cycle revealed that DO levels in the supernatant (above the sludge blanket) never dropped below $5 \mathrm{mg}$ DO/L in any of the SBRs. Anoxic conditions only occurred during static fill and only within the settled sludge blanket, which occupied a small fraction of the total SBR volume. 
What should have been mixed anoxic fill (mixing without aeration during feed) was actually a mixed aerobic fill.

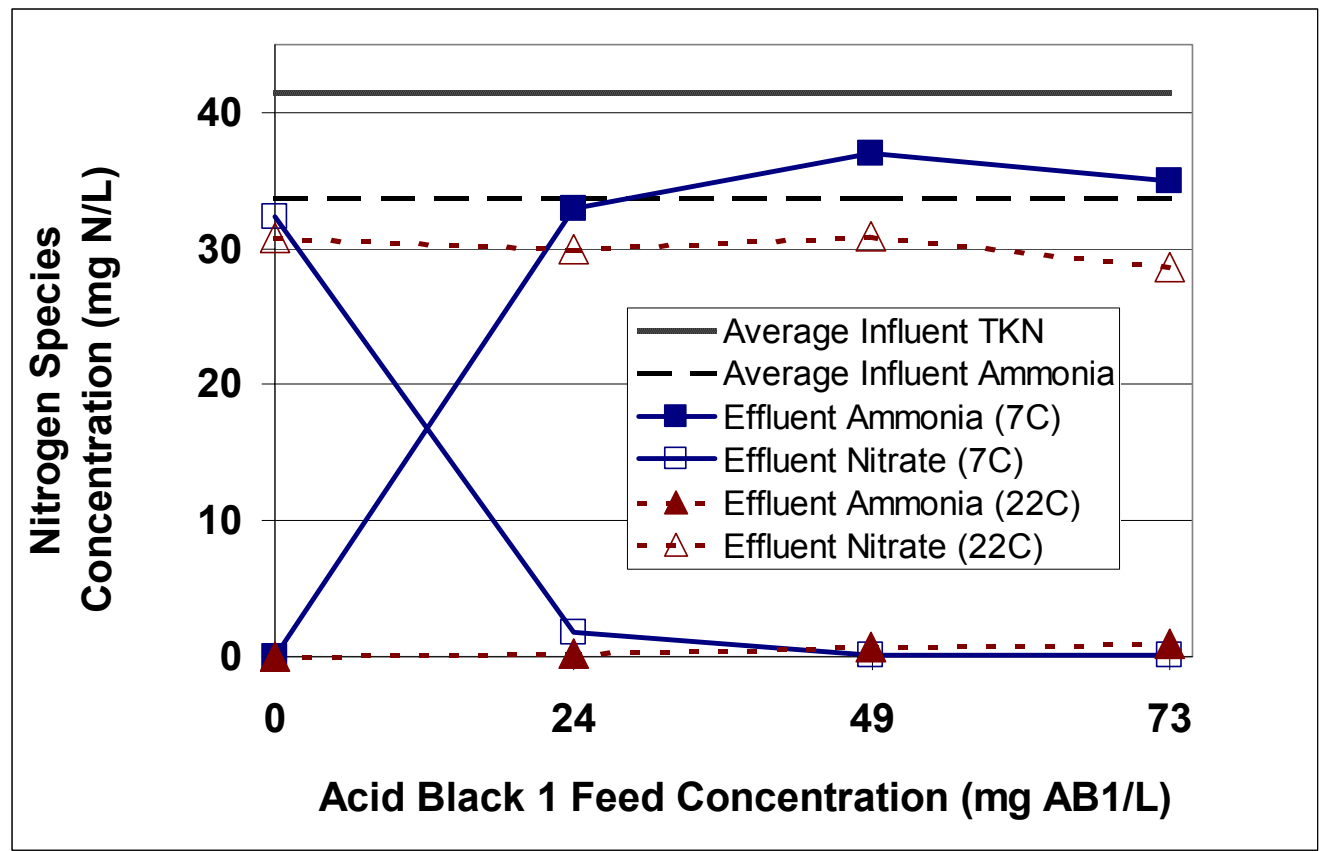

Figure 2.3 - Concentration Profile of Various Nitrogen Species in Cold $\operatorname{Room}\left(7^{\circ} \mathrm{C}\right)$ and at Room Temperature $\left(22^{\circ} \mathrm{C}\right)$ at Stable Reactor Conditions.

Although all eight reactors initially achieved similar $\mathrm{NH}_{3}$ removals, over time, $\mathrm{NH}_{3}$ removal declined in the reactors fed dye. In the cold room SBRs, nitrification failed more rapidly as the feed dye concentration increased. Figure 2.4 shows $\mathrm{NH}_{3}$ removal stopped at approximately 38 days (1.4 ESRTs) after start-up for the $9 \%(\mathrm{v} / \mathrm{v})$ dyeing discharge in the feed, compared to 45 days (1.6 ESRTs) for $6 \%(\mathrm{v} / \mathrm{v})$ discharge, and 52 days (1.9 ESRTs) for 3\% (v/v) discharge. In contrast, Figure 2.5 showed slight, but significant, nitrification inhibition in the room temperature SBRs with $99.9 \%, 99.3 \%, 97.9 \%$, and $97.0 \% \mathrm{NH}_{3}$ removal for the room temperature SBRs fed 0\% (control), 3\%, 6\%, and 9\% (v/v) dyeing operation discharge, respectively. This corresponds to effluent $\mathrm{NH}_{3}$ concentrations of $0.03,0.23,0.69$, and $1.0 \mathrm{mg} / \mathrm{L}$ 
$\mathrm{NH}_{3}-\mathrm{N}$ for the room temperature SBRs fed 0\% (control), 3\%, 6\%, and 9\% (v/v) dyeing operation discharge, respectively.

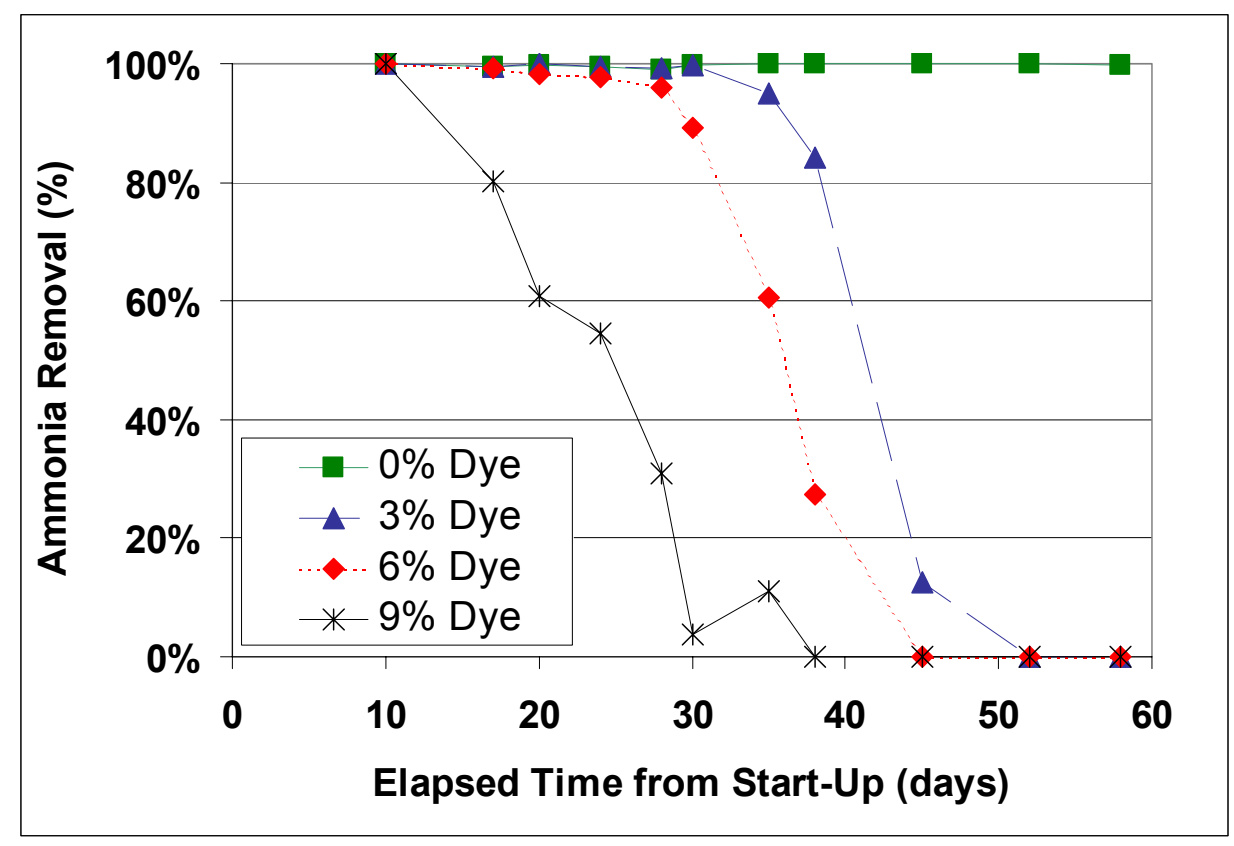

Figure 2.4 - Cold Room ( $\left.7^{\circ} \mathrm{C}\right)$ Ammonia Removal During Experimental Period.

Daigger and Sadick (1998) similarly documented low temperature nitrification inhibition by hydrocyanic acid (in incinerator flue-gas scrubber water) at a conventional activated sludge WWTP. Cyanide reduced the nitrifier activity at all temperatures, but high effluent $\mathrm{NH}_{3}$ concentrations were only noticeable at low wastewater temperatures. The combined effects of both cyanide and low temperature resulted in poor effluent quality data only during the colder water period. Similarly, in this study, the combination of AB1 and low temperature resulted in poor effluent quality only in the cold room reactors. 


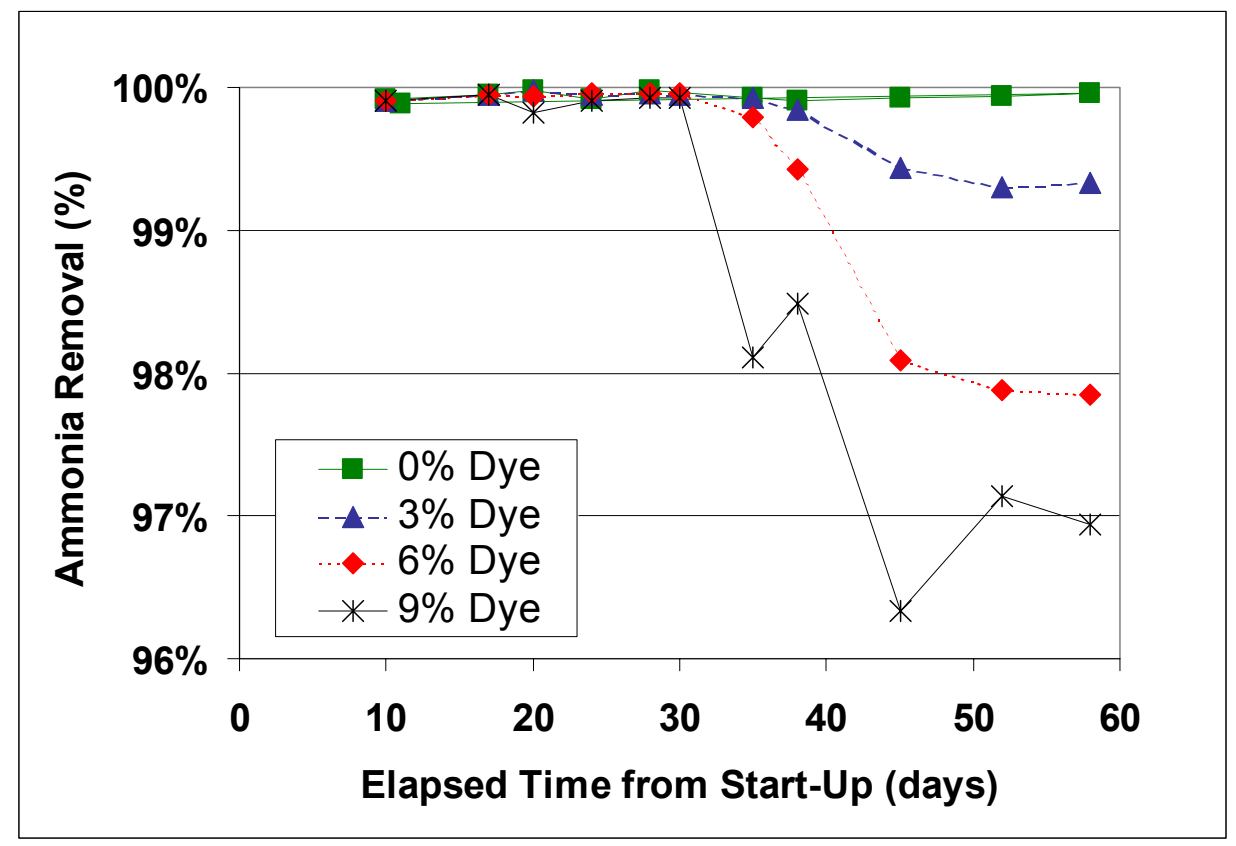

Figure 2.5 - Room Temperature $\left(22^{\circ} \mathrm{C}\right)$ Ammonia Removal During Experimental Period.

2.3.3 Additional Performance Characteristics. An increase in $\mathrm{pH}$ and the absence of alkalinity consumption also indicated nitrification failure in the cold room SBRs fed dye-bearing wastewater. At stable reactor conditions, the alkalinity decreased by approximately $230 \mathrm{mg}$ $\mathrm{CaCO}_{3} / \mathrm{L}$ in the control SBRs and by approximately $190 \mathrm{mg} \mathrm{CaCO} / \mathrm{L}$ in the room temperature SBRs fed dye-bearing wastewater. This corresponds to approximately $6.6 \mathrm{mg} \mathrm{HCO}_{3}{ }^{-}$consumed per $\mathrm{mg} \mathrm{NH} \mathrm{NH}_{3}-\mathrm{N}$ oxidized to $\mathrm{NO}_{3}-\mathrm{N}$ in the control SBRs and approximately $6.0 \mathrm{mg} \mathrm{HCO}_{3}{ }^{-}$ consumed per mg $\mathrm{NH}_{3}-\mathrm{N}$ oxidized to $\mathrm{NO}_{3}-\mathrm{N}$ in the room temperature SBRs fed dye-bearing wastewater. This is close to the theoretical value determined by Bitton (1999) of $7.14 \mathrm{mg}^{\mathrm{HCO}_{3}}{ }^{-}$ consumed per mg $\mathrm{NH}_{3}-\mathrm{N}$ oxidized to $\mathrm{NO}_{3}-\mathrm{N}$. In the cold room SBRs fed dye-bearing wastewater, the $\mathrm{pH}$ increased above 8.2 while the $\mathrm{pH}$ in the other SBRs remained below 7.5. 
Figure 2.6 shows removal of organic nitrogen as a function of $\mathrm{AB} 1$ concentration. Removal of organic nitrogen, which is biodegraded to ammonia by heterotrophs, decreases with increasing dye concentration at both room temperature and in the cold room. Figure 2.7 shows COD removal as a function of time. The dye-bearing wastewater reduced COD removal by as much as $50 \%$ in the cold room SBRs. Less COD was removed (up to $20 \%$ ) in the room temperature SBRs (data not shown). Analysis of the soluble fractions of the feed and effluent (data not shown) indicated lower soluble $\mathrm{BOD}_{5}$ and lower soluble COD removal in the cold room SBR fed dye-bearing wastewater and lower soluble $\mathrm{BOD}_{5}$ removal in the room temperature SBR fed dye-bearing wastewater. Only $35 \%$ of the soluble $\mathrm{BOD}_{5}$ was removed in the cold room SRB fed 9\% (v/v) dye-bearing wastewater and $95 \%$ of the soluble $\mathrm{BOD}_{5}$ was removed in the room temperature SRB fed 9\% (v/v) dye-bearing wastewater compared to greater than $99 \%$ soluble $\mathrm{BOD}_{5}$ removal in the two control SBRs. Soluble COD removal was $45 \%$ in the cold room SRB fed $9 \%(\mathrm{v} / \mathrm{v})$ dye-bearing wastewater compared to approximately $60 \%$ soluble COD removal in the room temperature SRB fed 9\% (v/v) dye-bearing wastewater and the two control SBRs.

Table 2.6 shows that effluent TSS was almost three times higher in the cold room SBRs fed $6 \%$ and $9 \%$ dye and almost twice as high in the cold room SBR fed 3\% dye when compared to the cold room control SBR. Table 2.7 shows that both endogenous and exogenous oxygen uptake by the activated sludge decreased (by 50\% and 90\%, respectively) in the cold room SBRs fed $9 \%$ dyeing operation discharge. Neither endogenous nor exogenous oxygen uptake was affected in the room temperature SBRs fed $9 \%$ dyeing operation discharge. 


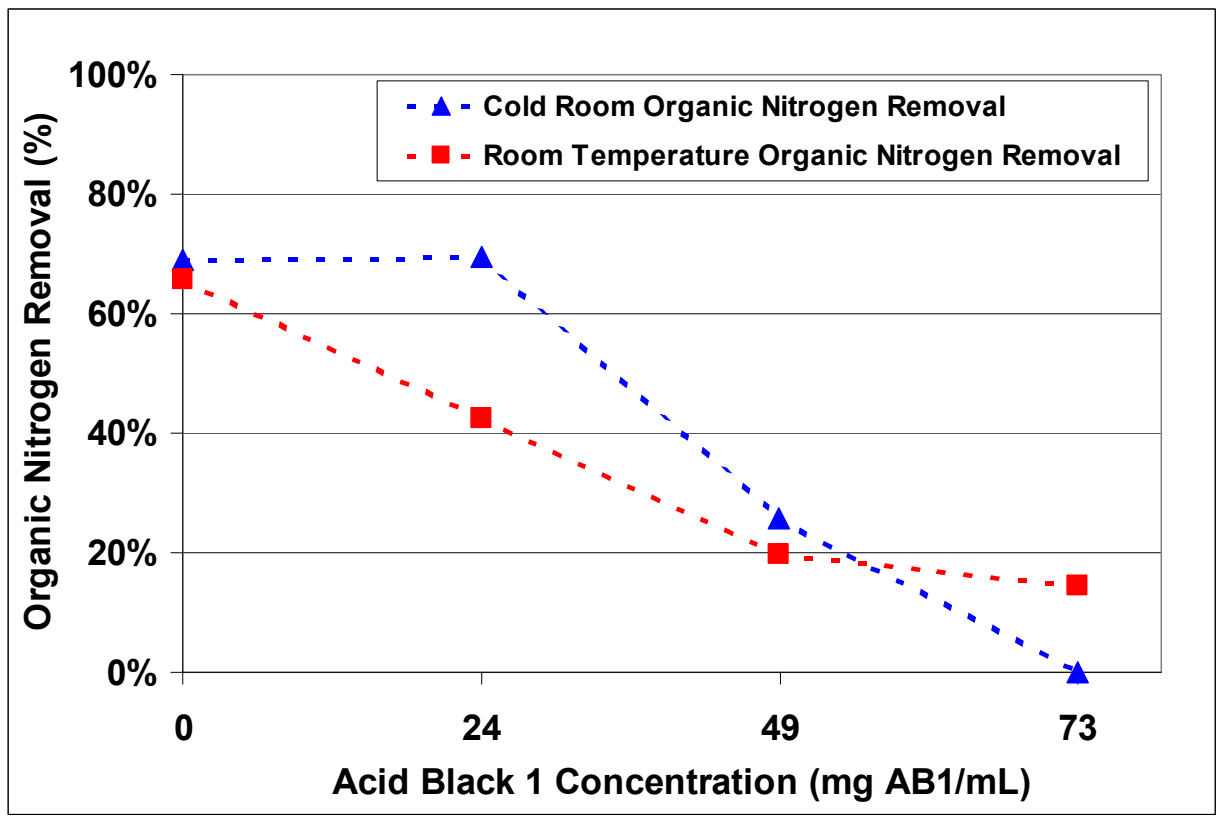

Figure 2.6 - Organic Nitrogen Removal in Cold Room $\left(7^{\circ} \mathrm{C}\right)$ and Room Temperature $\left(22^{\circ} \mathrm{C}\right)$ during Stable Reactor Conditions.

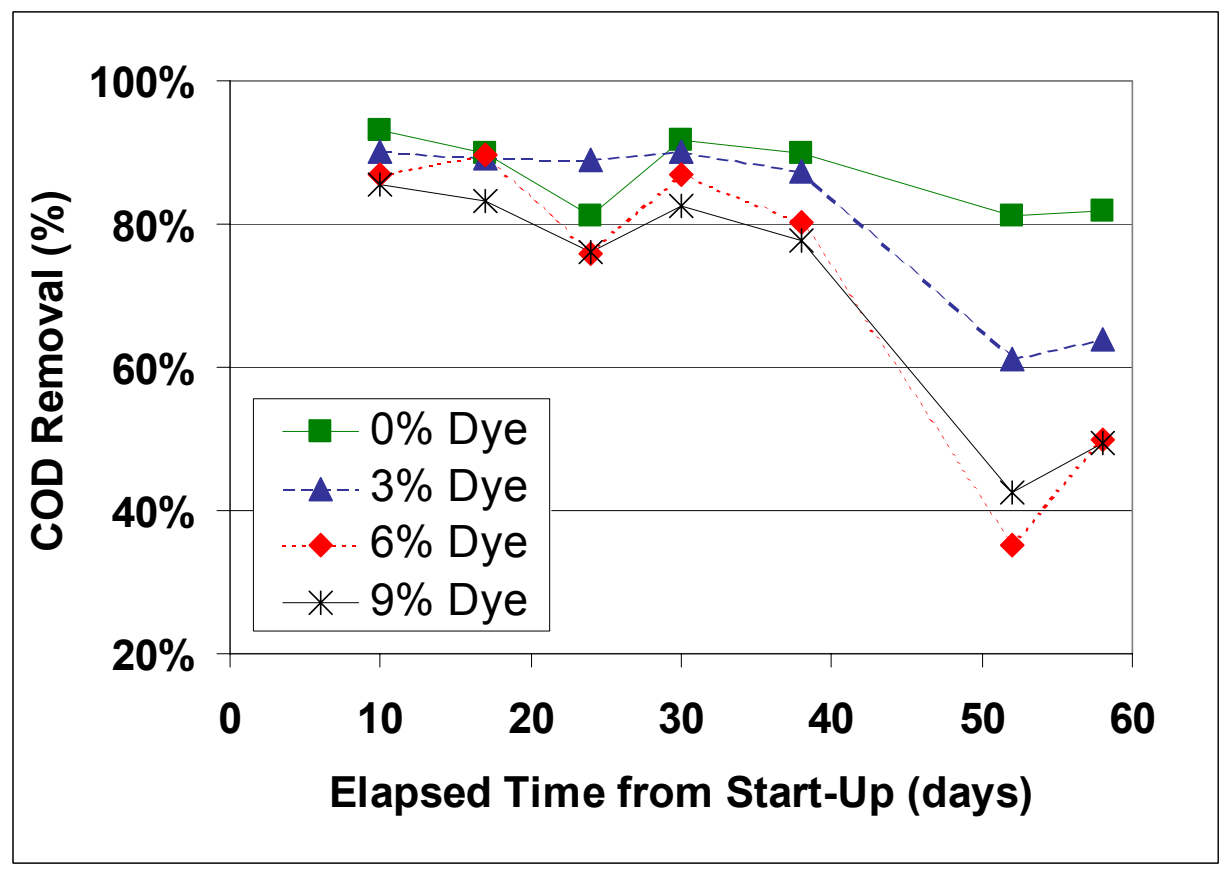

Figure 2.7 - Cold Room $\left(7^{\circ} \mathrm{C}\right)$ COD Removal During Experimental Period. 
Table 2.6: Tabulation of Cold Room $\left(7^{\circ} \mathrm{C}\right)$ Effluent TSS Concentration

\begin{tabular}{|c|c|c|}
\hline $\begin{array}{c}\text { SBR } \\
\text { Number }\end{array}$ & $\begin{array}{c}\text { Dyeing } \\
\text { Discharge (v/v) }\end{array}$ & $\begin{array}{c}\text { Effluent } \\
\text { TSS (mg/L) }\end{array}$ \\
\hline 1 & $0 \%($ control) & 26 \\
\hline 2 & $3 \%$ & 46 \\
\hline 3 & $6 \%$ & 71 \\
\hline 4 & $9 \%$ & 68 \\
\hline
\end{tabular}

Table 2.7: Tabulation of Oxygen Uptake Measurements of Activated Sludge

\begin{tabular}{|c|c|c|c|c|}
\hline $\begin{array}{c}\text { SBR } \\
\text { Temperature }\end{array}$ & $\begin{array}{c}\text { SBR } \\
\text { Number }\end{array}$ & $\begin{array}{c}\text { Dyeing } \\
\text { Discharge } \\
(\mathbf{v} / \mathbf{v})\end{array}$ & $\begin{array}{c}\text { Endogenous } \\
\text { Oxygen Uptake } \\
\left(\mathrm{mg} \mathrm{O}_{2} / \mathrm{g} \text { MLVSS-hr) }\right.\end{array}$ & 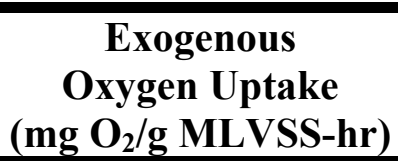 \\
\hline \multirow{2}{*}{$\begin{array}{l}\text { Cold Room } \\
\left(7^{\circ} \mathrm{C}\right)\end{array}$} & 1 & $0 \%$ (control) & 1.7 & 11 \\
\hline & 4 & $9 \%$ & 0.87 & 1.1 \\
\hline \multirow{2}{*}{$\begin{array}{c}\text { Room Temp. } \\
\left(22^{\circ} \mathrm{C}\right)\end{array}$} & 5 & $0 \%$ (control) & 3.9 & 32 \\
\hline & 8 & $9 \%$ & 3.9 & 35 \\
\hline
\end{tabular}

Furthermore, the quality of the activated sludge in all SBRs fed dye-bearing wastewater deteriorated, as indicated by excessive foaming and by the presence of filamentous bacteria. The most foaming occurred in the cold room SBRs fed $6 \%$ and $9 \%(\mathrm{v} / \mathrm{v})$ dye-bearing wastewater. According to Grady et al. (1999), foaming is primarily due to Nocordia and Microthrix parvicella and a low food to microorganism $(\mathrm{F} / \mathrm{M})$ ratio can cause foaming with $M$. parvicella present in the activated sludge. The F/M ratios in the SBRs that experienced foaming averaged $0.030 \mathrm{lb} \mathrm{BOD}$ applied per day/lb MLVSS and varied from 0.02 to $0.05 \mathrm{lb} \mathrm{BOD}_{5}$ applied per day/lb MLVSS which is below the SBR design range of 0.05 to $0.30 \mathrm{lb} \mathrm{BOD}_{5}$ applied per day/lb MLVSS specified by Tchobanoglous and Burton (1991). Foaming may also have been aggravated by high air flow rates in each reactor. Microscopic examination (at 100X magnification) shown in Figure 2.8 revealed excessive filamentous bacteria in the activated sludge from the cold room SBR fed 9\% (v/v) dye-bearing wastewater. 


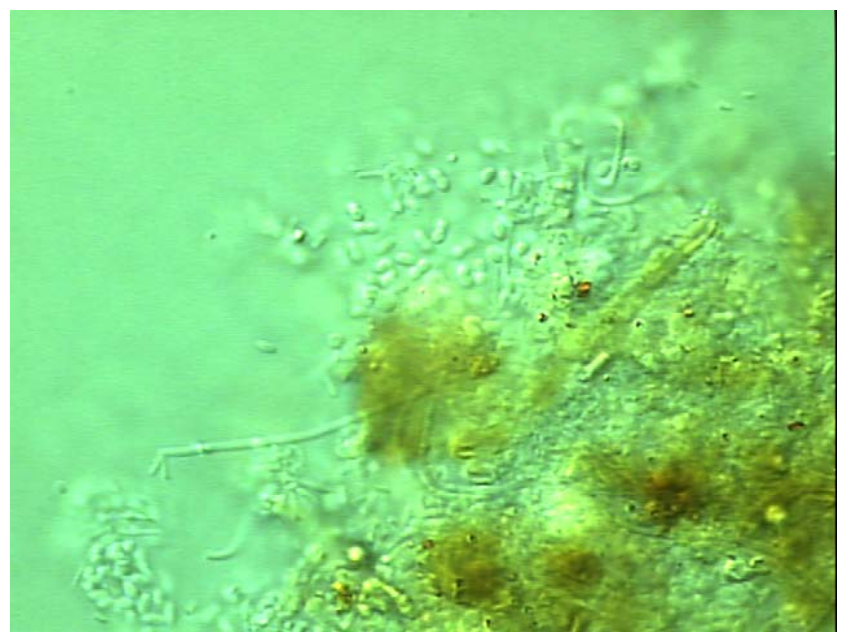

(a)

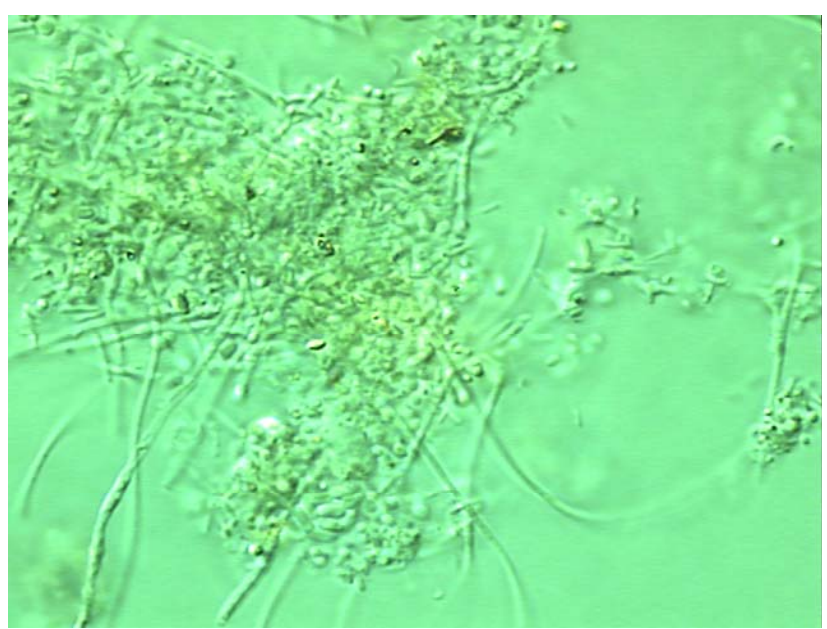

(b)

Figure 2.8 - (a) Activated Sludge from Sequencing Batch Reactor 1 Fed 0\% (v/v) Dyebearing Wastewater at $7^{\circ} \mathrm{C}$; (b) Sequencing Batch Reactor 4 Fed 9\% (v/v) Dye-bearing Wastewater at $7^{\circ} \mathrm{C}$ (Both Magnified 100X).

One concern was that the MLSS in all SBRs dropped to levels significantly lower than those found in typical suspended growth treatment systems. The cold room SBRs had a MLSS of $1,173 \pm 75 \mathrm{mg} / \mathrm{L}$ while the room temperature SBRs had a MLSS of $591 \pm 42 \mathrm{mg} / \mathrm{L}$. However, the non-inhibited SBRs were able to achieve pollutant removal even at these low MLSS. Nitrification can occur at the low MLSS because nitrifiers grow slowly and produce little biomass; "as a result, they may make a negligible contribution to MLSS concentration even when they have a significant effect on process performance" (Grady et al., 1999). O’Neill et al. (2000b) found "biomass growth in the activated sludge stage was limited by carbon source" noting that the MLSS decreased from approximately 4,000 $\mathrm{mg} / \mathrm{L}$ to $1,000 \mathrm{mg} / \mathrm{L}$ when the feed concentration of starch was decreased from $3.8 \mathrm{mg} / \mathrm{L}$ to $1.9 \mathrm{mg} / \mathrm{L}$; MLSS then increased after the starch concentration was again increased to $3.8 \mathrm{mg} / \mathrm{L}$. Grady et al. (1999) suggests nutrient ratios for biological nitrogen removal of $\mathrm{BOD}_{5} / \mathrm{NH}_{3}-\mathrm{N}>4$ and $\mathrm{BOD}_{5} / \mathrm{TKN}>2.5$. In this study, $\mathrm{BOD}_{5} / \mathrm{NH}_{3}-\mathrm{N}$ ranged from 2.2 to 4.0 and $\mathrm{BOD}_{5} / \mathrm{TKN}$ ranged from 1.8 to 3.6 , indicating 
insufficient carbon source. This is likely due to the low $\mathrm{BOD}_{5}$ concentration in the wastewater collected from the lift station feeding the WWTP, which averaged $89 \pm 15 \mathrm{mg} \mathrm{BOD}_{5} / \mathrm{L}$ during this study. This is less than $40 \%$ of the $\mathrm{BOD}_{5}$ concentration at the WWTP inlet, which averaged $228 \pm 53 \mathrm{mg} \mathrm{BOD} / \mathrm{L}$.

During the final week of the study, the AB1 loading to the SBRs was reduced to see if the activated sludge would recover. AB1 loading was decreased (by 75\%) by decreasing the $\mathrm{AB} 1$ concentration in the feed (using only the less concentrated discharge from the continuous rinsing operations) and by reducing the feed flow rate (by between $10 \%$ and $20 \%$ ). Decreasing the AB1 loading to the cold room SBRs led to partial nitrification recovery indicated by $\mathrm{NO}_{3}{ }^{-}$production of $11 \mathrm{mg} \mathrm{NO}_{3}{ }^{-} / \mathrm{L}, 1.0 \mathrm{mg} \mathrm{NO}_{3}-\mathrm{L}$, and $0.10 \mathrm{mg} \mathrm{NO}_{3}{ }^{-} / \mathrm{L}$ in the SBRs fed 3\%, 6\%, and $9 \%(\mathrm{v} / \mathrm{v})$ dyeing operation discharge, respectively. There was also a slight improvement in COD removal. Although $\mathrm{NH}_{3}$ removal did not improve, one week may not have been long enough for complete recovery. Nitrification recovery (after reducing AB1 loading) would indicate that the nitrifiers were inactivated instead of killed. Nitrification inhibition by AO7 was due to decreased nitrifier activity, not nitrifier death (He and Bishop, 1994). AB1 and AO7 are both sulphonated azo dyes having two common chemical structures: a naphthyl radical containing a hydroxyl functional group adjacent to the azo bond and a phenyl radical unsubstituted adjacent to the azo bond.

Although the concentration of $\mathrm{AB} 1$ in the effluent was not measured, observations indicated that the dye concentration was significantly higher in the feed than in the effluent. The activated sludge in the reactors fed AB1 was also darker than in the control reactors indicating that some AB1 may have been sorbed onto the activated sludge. Shaul et al. (1988) reported only $2 \%$ to $6 \%$ of $\mathrm{AB} 1$ in feed sewage was sorbed onto the activated sludge with no apparent dye biodegradation; however, this was for a continuous flow activated sludge system with the SRT 
and HRT less than one tenth of those in this study, so more AB1 could have been sorbed onto the sludge in this study.

2.3.4 Potential Solutions. While further investigation is required to determine the most appropriate methods to reduce the impact of the dyeing operation discharge on the WWTP, several options may be feasible. Treatment of the AB1 dye-bearing wastewater may be possible by anaerobic digestion (possibly followed by aerobic treatment) or by addition of powdered activated carbon to the aeration tanks at the WWTP. Another option is on-site pretreatment by methods such as reduction followed by oxidation, coagulation and precipitation, lime precipitation, or adsorption by activated carbon or other sorbents. Pollution prevention (i.e. waste minimization, dye substitution, reuse, and/or equalization) is a potential strategy for reducing the dye concentration in the wastewater and it may reduce dye concentration to a noninhibitory level. Eliminating dye-bearing wastewater discharge to the WWTP during the winter (by hauling or storage) would also prevent cold weather nitrification failure at the WWTP.

Eventually, the dyeing industry relocated to another community. Eliminating this dyebearing wastewater discharge to the full-scale WWTP resulted in significantly improved performance and brought the WWTP into compliance with regulatory discharge limits. Results from this research and the full-scale WWTP demonstrate the complete nitrification failure at low temperature due to dye-bearing wastewater which contained AB1, emphasizing the importance of ascertaining inhibition at the lowest WWTP operating temperature.

\subsection{CONCLUSIONS}

1. Dye-bearing wastewater containing the azo dye AB1 at concentrations as low $24 \mathrm{mg} \mathrm{AB1/L}$ inhibited nitrification after the reactors reached stable conditions. The combined effect of low 
temperature and dye-bearing wastewater caused complete nitrification failure at $7^{\circ} \mathrm{C}$ within 2 ESRTs. Nitrification inhibition at $22^{\circ} \mathrm{C}$ was much less than at $7^{\circ} \mathrm{C}$, but significant: $97.0 \% \mathrm{NH}_{3}$ removal for $73 \mathrm{mg} \mathrm{AB1/L}$ compared to $99.9 \%$ for the $22^{\circ} \mathrm{C}$ control.

2. All reactors initially performed comparably, but over time, $\mathrm{NH}_{3}$ and $\mathrm{COD}$ removal declined in all reactors fed dye. As the concentration of $\mathrm{AB} 1$ in the $7^{\circ} \mathrm{C}$ wastewater increased, nitrification and COD removal failed earlier. For $24 \mathrm{mg} \mathrm{AB1/L}, 49 \mathrm{mg} \mathrm{AB} 1 / \mathrm{L}$, and $73 \mathrm{mg}$ $\mathrm{AB} 1 / \mathrm{L}$, the nitrification failure occurred in 52 days, 45 days, and 38 days after start-up, respectively.

3. Decreasing the $\mathrm{AB} 1$ loading (by $77 \%$ ) in the wastewater feed at $7^{\circ} \mathrm{C}$ led to partial nitrification recovery within one week as indicated by significant $\mathrm{NO}_{3}{ }^{-}$production and a slight improvement in COD removal; however, there was no corresponding increase in $\mathrm{NH}_{3}$ removal.

4. The presence of AB1-bearing wastewater led to additional deterioration in the activated sludge process. COD removal decreased by as much as $50 \%$ at $7{ }^{\circ} \mathrm{C}$ and by as much as $20 \%$ at $22^{\circ} \mathrm{C}$; effluent TSS increased nearly three-fold at $7^{\circ} \mathrm{C}$; both endogenous and exogenous oxygen uptake decreased and foaming increased at $7^{\circ} \mathrm{C}$.

5. The combined effects of both $\mathrm{AB} 1$ and low temperature resulted in poor effluent quality at $7^{\circ} \mathrm{C}$, emphasizing the importance of ascertaining inhibition at the lowest WWTP operating temperature. 


\subsection{ACKNOWLEDGEMENTS}

2.5.1 Credits. This research was partially supported by Donohue \& Associates (Sheboygan, WI) with input provided by Ken Sedmack. During this project, Ron Martin, Jr. was supported as a Michigan Technological University Graduate School Ph.D. and as a U.S. Department of Education Graduate Assistantship in Areas of National Need (GAANN) Ph.D. fellow. Christopher L. Wojick helped to design and construct the experimental equipment, Sue E. Bunzendahl assisted with collection and analysis of samples, and David L. Perram provided advice on analytical methods and technique (all of Michigan Technological University). Any opinions, findings, conclusions, or recommendations expressed in this paper are those of the authors and do not necessarily reflect the view of the supporting organizations.

2.5.2 Authors. Ron Martin, Jr. is enrolled in the Environmental Engineering Ph.D. program at Michigan Technological University. C. Robert Baillod is a Professor and Chair in the Department of Civil and Environmental Engineering and James R. Mihelcic is a Professor in the Department of Civil and Environmental Engineering at Michigan Technological University. Correspondence should be addressed to C. Robert Baillod, Department of Civil and Environmental Engineering, Michigan Technological University, 1400 Townsend Drive, Houghton, MI, 49931, email: baillod@mtu.edu.

\subsection{REFERENCES}

American Public Health Association; American Water Works Association; and Water Environment Federation (1992) Standard Methods for the Examination of Water and Wastewater. 18th Ed, edited Greenberg, A.E.; Clesceri, L.S.; and Eaton, A.D., Washington, D.C. 
Åstrand, P.-O.; Ramanujam, P. S.; Hvilsted, S.; Bak, K.L.; and Sauer, S.P.A. (2000) Ab Initio Calculation of the Electronic Spectrum of Azobenzene Dyes and Its Impact on the Design of Optical Data Storage Materials. J. Am. Chem. Soc., 122 (14), 3482 -3487.

Bitton, G. (1999) Wastewater Microbiology. 2nd Ed., Wiley-Liss (A John Wiley \& Sons, Inc. Publication), New York.

Brown, D., and Hamburger, B. (1987) The Degradation of Dyestuffs: Part III - Investigation of Their Ultimate Degradability. Chemosphere, 16(7), 1539-1553.

Brown, D.; Hitz, H.R.; and Schafer, L. (1981) The Assessment of the Possible Inhibitory Effect of Dye-stuffs on Aerobic Wastewater Bacteria Experience with a Screening Test. Chemosphere, 10(3), 245-261.

Burg, A.W., and Charest, M. C. (1980) Azo Dyes: Evaluation of Data Relevant to Human Health and Environmental Safety. Report C-82875 to the Dyes Environmental and Toxicology Organization, Arthur D. Little, Inc. and the Ecological and Toxicological Association of the Dyestuffs Manufacturing Industry (ETAD), Basel, Switzerland.

Daigger, G.T., and Sadick, T.E. (1998) Evaluation of Methods to Detect and Control Nitrification Inhibition with Specific Application to Incinerator Flue-Gas Scrubber Water. Water Env. Res., 70(7), 1246-1257. 
Environmental Protection Agency (1983) Methods of Chemical Analysis of Water and Wastes.

US EPA/600/4-79-020, US Environmental Protection Agency, Environmental Monitoring Systems Laboratory (EMSL), Cincinnati, $\mathrm{OH}$.

Fu, Y.C.; Jiang, H.; and Bishop, P. (1994) An Inhibition Study of The Effect of Azo Dyes on Bioactivity of Biofilms. Wat. Sci. Tech., ASCE, 29(7), 365-372.

Furukawa, K.; Kuroki, S.; and Nakaoka, M. (1999) Biodegradation Azo Dyes Under Photodependent Anoxic Conditions. Proc. Water Environ. Fed. 72nd Annu. Conf. Exposition [CDROM], New Orleans, La.

Grady, C.P.L. Jr.; Daigger, G.T.; and Lim, H.C. (1999) Biological Wastewater Treatment, 2nd Ed., Marcel Dekker, Inc., New York.

Harmer, C., and Bishop, P. (1992) Transformation of Azo Dye AO-7on by Wastewater Biofilms. Wat. Sci. Tech., 26(3-4), 627-636.

He, Y., and Bishop, P.L. (1994) Effect of Acid Orange 7 on Nitrification Process. J. Envir. Eng., 120(1), 108-121.

McCurdy, M.W.; Boardman, G.D.; Michelsen, D.L.; and Woodby, B.M. (1992) Chemical Reduction and Oxidation Combined with Biodegradation for the Treatment of a Textile Dye Wastewater. 46th Ind. Waste Conf. Proc., Conference Date 1991, 46, 229-234. 
Nigam, P.; Banat, I.M.; Singh, D.; and Marchant, R. (1996) Microbial Process for the Decolorization of Textile Effluent Containing Azo, Diazo and Reactive Dyes. Process Biochemistry, 31(5), 435-442.

O’Neill, C.; Hawkes, F.R.; Hawkes, D.L.; Esteves, S.; and Wilcox, S.J. (2000b) AnaerobicAerobic Biotreatment of Simulated Textile Effluent Containing Varied Ratios of Starch and Azo Dye. Wat. Res., 34(8), 2355-2361.

O’Neill, C.; Lopez, A.; Esteves, S.; Hawkes, F.R.; Hawkes, D.L.; and Wilcox, S. (2000a) AzoDye Degradation in and Anaerobic-Aerobic Treatment System Operating on Simulated Textile Effluent. Appl. Microbiol. Biotechnol., 53(2), 249-254.

Razo-Flores, E.; Luijten, M.; Donlon, B.; Lettinga, G.; and Field, J. (1997) Complete

Biodegradation of the Azo Dye Azodisalicylate Under Anaerobic Conditions. Environ. Sci. Technol., 31(7), 2098-2103.

Shaul, G.M.; Dempsey, C.R.; and Dostal, K.A (1988) Fate of Water Soluble Azo Dyes in the Activated Sludge Process. US EPA/600/S2-88/030, US Environmental Protection Agency, Water Engineering Research Laboratory, Cincinnati, OH.

Tchobanoglous, G., and Burton, F.L. (1991) Wastewater Engineering Treatment, Disposal, and Reuse. 3rd Ed. Metcalf \& Eddy, Inc. Published by Irwin/McGraw-Hill (a division of the McGraw-Hill Companies. Boston, MA. 
Tong, A., and Young, R. A. (1974) An Investigation into the Pretreatment and Effect of an Industrial Waste Water Derived from the Manufacture of Azo Dyes upon the Activated-Sludge Process. Water Pollut. Control, 73(5), 584-588.

Vandevivere, P.C.; Bianchi, R.; and Verstraete, W. (1998) Review: Treatment and Reuse of Wastewater from the Textile Wet-Processing Industry: Review of Emerging Technologies. $J$. Chem. Technol. Biotechnol., 72(4), 289-302.

Zaoyan, Y.; Ke, S.; Guangliang, S.; Fan, Y.; Jinshan, D.; and Huanian, M. (1992) AnaerobicAerobic Treatment of a Dye Wastewater by Combination of RBC with Activated Sludge. Wat. Sci. Tech., 26(9-11), 2093-2096. 


\title{
CHAPTER 3
}

\section{OPTIMIZATION OF BIOFILTRATION FOR ODOR CONTROL: MODEL CALIBRATION, VALIDATION, AND APPLICATIONS*}

\begin{abstract}
A dynamic model that describes the biofiltration process for hydrogen sulfide removal from wastewater treatment plant air emissions was calibrated and validated using pilot- and full-scale biofilter data obtained from the Cedar Rapids (Iowa) Water Pollution Control Facilities. After calibration, the model was found to predict the dynamic effluent concentrations of the pilot- and full-scale biofilters very well, with the measured data falling within 58 to $80 \%$ of the model output values. In addition, the model predicted the trend of the field data even under field conditions of changing input concentration and at effluent concentrations below 1 ppm by volume. The model demonstrated that increasing gas residence time and temperature and decreasing influent concentration decreases effluent concentration. In addition, model simulations showed that a longer residence time is required to treat dynamic loading increases, indicating that biofilter design should account for the maximum influent concentration. These results can be used to assist in the design and operation of biofilters for control of odorous and hazardous air emissions.
\end{abstract}

KEYWORDS: Biofilter, biofilm, biological treatment, hydrogen sulfide, model calibration and validation, odor, organic sulfur compounds, pilot plant, VOC, wastewater.

\footnotetext{
* Reprinted with permission from Martin Jr., R. W.; Li, H.; Mihelcic, J. R.; Crittenden, J. C.; Lueking, D. R.; Hatch, C. R.; Ball, P. (2002) Optimization of Biofiltration for Odor Control: Model Calibration, Validation, and Applications. Water Environ. Res., 74, 17. Copyright 2002 Water Environment Federation, Alexandria, VA.
} 


\subsection{INTRODUCTION}

In a companion study (Li et al., 2002) a dynamic model that can simulate the performance of a biofilter used to control odorous hydrogen sulfide $\left(\mathrm{H}_{2} \mathrm{~S}\right)$ emissions was developed and verified, and a parameter sensitivity analysis was conducted. The model, which has been packaged as a user-friendly software program called Biofilter ${ }^{\mathrm{TM}}$ (Michigan Technological University, Houghton, Michigan), provides a tool for the design and optimization of biofilters used for controlling odorous air emissions. The objectives of this study are to present the calibration and validation of the biofilter model using pilot- and full-scale data from the Cedar Rapids (Iowa) Water Pollution Control Facilities (WPCF) and then demonstrate some of the model's practical applications. These practical applications include the influence that gas residence time, influent concentration, temperature, and dynamic loading have on biofilter performance and design.

Although a much less complex biofiltration model has been compared to laboratory-scale experimental data for $\mathrm{H}_{2} \mathrm{~S}$ (McNevin et al. 1999), other laboratory studies have been directed at a wide variety of organic chemicals such as methyl ethyl ketone and methyl isobutyl ketone (Deshusses et al., 1995), benzene and toluene (Zarook et al., 1997), and volatile organic compounds (VOCs) (Amanullah, 1999). Although it is easy to control conditions such as temperature and loading in the laboratory, these conditions are more difficult to control in the field. In addition, the operational and performance problems of full-scale biofilters are different from those encountered in laboratory studies (Webster et al., 1999). Therefore, model parameters obtained from laboratory-scale data may not predict biofilter performance in the field. For this reason, pilot- and full-scale data from the Cedar Rapids WPCF were used to calibrate and validate the model in this study. Although Comas et al. (1999) conducted a pilot study with a 
bioscrubber to support a modeling effort, instead of changing the model parameters to fit the data they developed a correlation between the simulated effluent and the experimental effluent that is not easily used or compared by other researchers.

Finally, a major difference in the literature describing several types of biofilter designs for $\mathrm{H}_{2} \mathrm{~S}$ removal is the type of packing medium employed. For example, van Langenhove et al. (1986) used wood bark, Hirai et al. (1990) used peat, Yang and Allen (1994) used compost, Chung et al. (1996) used calcium-alginate pellets, Morton and Caballero (1996) used lava rock, and Wani et al. (1998) used various mixtures of compost, perlite, and hog fuel. The packing material used by the Cedar Rapids WPCF is lava rock. Accordingly, this paper also discusses issues related to the selection of the packing material and provides insight on some potentially beneficial properties of lava rock.

\subsection{MATERIALS AND METHODS}

3.2.1 Background. The Cedar Rapids WPCF receives an average flow of approximately $2.0 \mathrm{~m}^{3} / \mathrm{s}$ (45 MGD), have a design average flow of $2.5 \mathrm{~m}^{3} / \mathrm{s}$ (56 MGD), and a design peak flow of $4.8 \mathrm{~m}^{3} / \mathrm{s}(110 \mathrm{MGD})$. Approximately $70 \%$ of the flow contribution is from industrial discharges resulting in high influent concentrations of BOD ( $>500 \mathrm{mg} / \mathrm{L})$ and sulfate (250 to 400 $\mathrm{mg} / \mathrm{L})$.

Four roughing filters reduce the high BOD and chemical oxygen demand (COD) loading to the carbonaceous activated sludge (CAS) system, thus decreasing demand for the pure oxygen activated sludge aeration. A 1990 odor study by the Cedar Rapids WPCF indicated that $90 \%$ of odor emissions originated from the roughing filters, with additional odor emissions originating 
from three dissolved air flotation (DAF) thickeners, three primary clarifiers, and a Parshall flume that measures inlet flow.

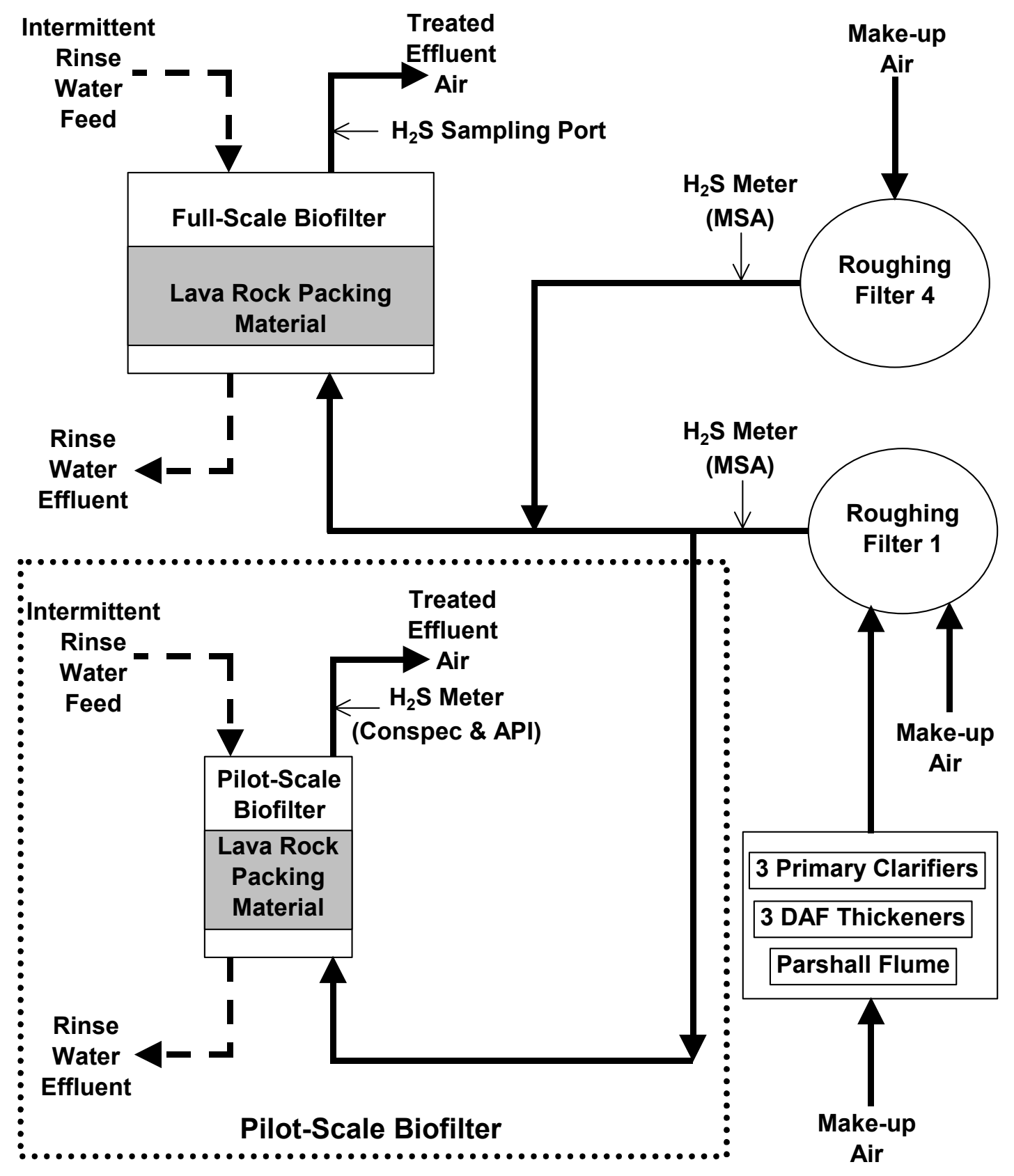

Figure 3.1-Process Flow Diagram for Pilot-Scale Biofilter (Located within Dashed Area and Used for Model Calibration and Validation) and Full-Scale Biofilter 1 (Used for Model Validation) at Cedar Rapids WPCF. Air Streams are Shown as Solid Lines and Intermittent Rinse Water Streams are Shown as Dashed Lines. 
Bacteria in the roughing filters reduce the sulfate to sulfide under the anaerobic conditions caused by high BOD loading. Additionally, any sulfide dissolved in the wastewater entering the roughing filters is stripped into the air as it is agitated while passing over the packing material. Although $\mathrm{H}_{2} \mathrm{~S}$ is the odorous contaminant present at the highest concentration, methyl mercaptan, carbonyl sulfide, ethyl mercaptan, dimethyl sulfide, carbon disulfide, and dimethyl disulfide have also been detected. While the model used in this study could be applied to the removal of organic reduced sulfur compounds and VOCs, the focus of this study was on $\mathrm{H}_{2} \mathrm{~S}$ removal.

3.2.2 Biofilters and Packing Medium. In 1998, Cedar Rapids WPCF began operation of two, parallel, full-scale biofilters. Each biofilter is $21.6-\mathrm{m}(71-\mathrm{ft})$ long by $11-\mathrm{m}(36-\mathrm{ft})$ wide. Biofilter 1 treats odorous air from roughing filters 1 and 4 while biofilter 2 treats odorous air from roughing filters 2 and 3. Each roughing filter has a blower on the air effluent that feeds the odorous air to the biofilters' upflow and draws ambient make-up air into the roughing filters. Roughing filter 1 also draws odorous air from the DAF thickeners (accounting for $45 \%$ of the total make-up air flow to roughing filter 1), primary clarifiers (14\%), and Parshall flume (4.5\%). Each biofilter has an exhaust stack with a blower that discharges effluent air to the atmosphere.

Figure 3.1 shows the process flow diagram for biofilter 1 as well as the pilot-scale biofilter and also includes the location of sampling points used for calibration and validation of the model. The pilot-scale biofilter consisted of a $0.608-\mathrm{m}(2.00-\mathrm{ft})$ inside diameter vertical fiberglass cylinder that was covered with insulation. An electric blower (IPF, Inc., Wakefield, Massachusetts, model CDD-180, $0.2 \mathrm{~m}^{3} / \mathrm{s}$ [400 cfm] and 1,725 rpm) pulled odorous air from roughing filter 1 effluent and fed it to the bottom of the pilot biofilter through a 15 -cm (6-in.) polyvinyl chloride (PVC) feed pipe that entered at the side of the biofilter column. Exhaust air 
exited through a $10-\mathrm{cm}$ (4 in.) diameter by $15-\mathrm{cm}$ (6-in.) long cylindrical stack that was offset 15 $\mathrm{cm}(6 \mathrm{in}$.) from the axial center on top of the column, with $0.9 \mathrm{~m}(3 \mathrm{ft})$ of headspace above the packing medium.

Both the full-scale biofilters and the pilot-scale biofilter were packed with lava rock to a depth of $1.83 \mathrm{~m}(6 \mathrm{ft})$. The lava rock had an average radius of $1.20 \mathrm{~cm}$ and a sphericity of 0.5 and the bed porosity was determined to be 0.40 . In both full-scale biofilters and the pilot biofilter, a PVC peg board, with $0.64-\mathrm{cm}(0.25$-in) holes that were $7.6 \mathrm{~cm}$ ( 3 in) apart, supported the lava rock above the gas feed and provided uniform air distribution through the beds.

To provide moisture and nutrients for the microorganisms and to prevent excess sulfate accumulation, which has been shown to decrease removal efficiency (Yang and Allen, 1994), CAS clarified effluent was sprayed on top of the lava rock beds via spray nozzles for 5 minutes every hour. The continuous air stream (fed upward from the bottom of the bed) and the intermittent rinse water flowed countercurrent, with spent rinse water collected in, and overflowing from, a sump located below the biofilters. The pilot biofilter was operated using an air residence time and rinse water feed flow rate (per bed volume) set approximately equal to that of the full-scale biofilters at the time of the pilot study.

3.2.3 $\mathrm{H}_{2} \mathrm{~S}$ Data Collection. The pilot study, initiated on January 17, 2000, collected two sets of data: the first in January and the second in March. Feed influent to the full-scale biofilters was measured by an individual Mine Safety Appliances (MSA) Company (Pittsburgh, Pennsylvania) odor monitoring system consisting of an $\mathrm{H}_{2} \mathrm{~S}$ meter dedicated to each of the four roughing filter effluent air pipes. The 4- to 20-mA output signal from each MSA meter was continuously recorded. The influent $\mathrm{H}_{2} \mathrm{~S}$ concentration to the pilot biofilter was measured using the MSA meter on roughing filter 1. Each MSA meter was calibrated monthly by WPCF staff. 
The MSA meter was crosschecked twice with a Conspec hydrogen sulfide monitor (series P2065-1 with a 0- to 80-ppm by volume $\left[\mathrm{ppm}_{\mathrm{V}}\right]$ concentration range) (Conspec Controls, Inc., Charleroi, Pennsylvania) when the pilot feed $\mathrm{H}_{2} \mathrm{~S}$ concentration was within the working range of the Conspec meter. The effluent from the full-scale biofilter was measured with a Jerome 631-X hydrogen sulfide analyzer (Arizona Instrument Corp., Phoenix, Arizona).

Several meters were used to measure the effluent $\mathrm{H}_{2} \mathrm{~S}$ concentrations from the pilot-scale biofilter. When the effluent $\mathrm{H}_{2} \mathrm{~S}$ concentration was high (corresponding to the first data collection in January), the effluent $\mathrm{H}_{2} \mathrm{~S}$ concentration was recorded from the digital readout of the Conspec meter. During the second data collection in March, the 4- to 20-mA output signal from the Conspec meter was continuously recorded during the period from 11 p.m. on March 7, 2000 to 11 a.m. on March 10, 2000. The Conspec meter was calibrated (according to the manufacturer's specifications) at the beginning of both data collections. Both the digital readout and the (4- to 20-mA) signal output were checked with standards (carbon filtered air for zero and 1-, 5-, and 40-ppm $\mathrm{v}$ standard $\mathrm{H}_{2} \mathrm{~S}$ gas), once during and once at the end of both data collection periods. An Advanced Pollution Instrumentation (API) (San Diego California) hydrogen sulfide analyzer (model 101A with a $0-$ to $20-\mathrm{ppm}_{\mathrm{v}}$ concentration range) was used to measure the effluent $\mathrm{H}_{2} \mathrm{~S}$ concentration during the low-concentration period (from 1 p.m. on March 10, 2000, to 6:30 p.m. on March 14, 2000). The 4- to 20-mA output signal from the API meter was continuously recorded. The inlet to the API meter was fitted with a stock $\mathrm{SO}_{2}$ scrubber $\left(\mathrm{SO}_{2}\right.$ will result in a high $\mathrm{H}_{2} \mathrm{~S}$ reading) and a hydrophobic filter (Whatman Puradisc 25TF, Whatman, Inc., Clifton, New Jersey) to protect the meter from moisture. The API meter was calibrated (according to the manufacturer's specifications) at the beginning of use and the (4- to 20-mA) 
output signal was checked with standards (carbon filtered air for zero and 1- and 5-ppm $\mathrm{v}$ standard $\mathrm{H}_{2} \mathrm{~S}$ gas) once during and once at the end of this period.

All $\mathrm{H}_{2} \mathrm{~S}$ meter sampling of effluent air was conduced from the exhaust stack on the top of the pilot biofilter column. For the continuous, 4- to 20-mA) signal output readings, an API (Model 101A) external vacuum pump was used to continuously pull effluent air samples through a $0.6-\mathrm{cm}(0.25$-in) i.d. polyethylene tubing running from the exhaust stack to a heated maintenance building. A water trap on top of the pilot biofilter column and a drying tube (containing Drierite [anhydrous calcium sulfate]) located in the building were used to remove moisture from the air sample.

3.2.4 Additional Data Collection. The odorous airflow to the pilot-scale biofilter was measured (as velocity) using both hot wire (series 471 Dwyer Instruments, Inc., Michigan City, Indiana and standard model Extech Instruments, Corp., Waltham, Massachusetts) and mechanical vane-type (model DA40V, Pacer Industries, Chippewa Falls, Wisconsin) hand-held digital anemometers. The pilot biofilter temperature, which varied in both the axial and radial directions of the biofilter bed, was measured at sample holes at various column depths by inserting the metal stem of a digital thermometer approximately $13 \mathrm{~cm}(5 \mathrm{in}$.$) into the biofilter,$ toward the column center. The temperature of the odorous feed air and the rinse water feed were also manually recorded. The rinse water effluent temperature and $\mathrm{pH}$ were measured in the sump with a Rosemont Analytical, Inc. (Irvine, California) pH/oxidation reduction potential meter (model 54, with a model 396P sensor). The rinse water flow was measured with a King Instrument Company (Garden Grove, California) 1.9- to 18.9-L/min (0.5- to 5.0-gpm) inline flow meter and maintained at $3.8 \mathrm{~L} / \mathrm{min}(1.0 \mathrm{gpm})$ during the 5 -minute rinse cycle. An Isco, Inc. (Lincoln, Nebraska) model 2910 sampler was used to collect composite samples for $\mathrm{pH}$ and 
sulfate analysis of feed and effluent (from the sump) rinse water. Measurements (not reported here) were also made of the BOD, total Kjeldahl nitrogen, total phosphate, conductivity, alkalinity, and total suspended solids in the rinse water influent and effluent.

3.2.5 Calibration and Validation Periods. The most suitable data set for model calibration would be from an extended period of relatively constant feed $\mathrm{H}_{2} \mathrm{~S}$ concentration and biofilter bed temperature. Such an ideal data set was not available because of the diurnal variation of BOD and sulfate loading to the roughing filters as well as the column temperature fluctuation. However, measured data from the pilot-scale biofilter in March (starting at 12:30 a.m. on March 8, 2000 and ending at 7:30 a.m. on March 14,2000) with a relatively constant feed $\mathrm{H}_{2} \mathrm{~S}$ concentration and a relatively constant column temperature was determined to be appropriate for the model calibration period.

For the model validation period, measured data from the pilot-scale biofilter obtained in January were used (starting at 2:30 p.m. on January 17, 2000 and ending at 1:30 p.m. on January $27,2000)$. An additional model validation data set was obtained using measured data from the full-scale biofilter for a 26-day period (starting at noon on October 9, 1998 and ending at 1:30 p.m. on November 3,1998$)$. Unlike the continuously measured $\mathrm{H}_{2} \mathrm{~S}$ concentration data for the pilot-scale study, the full-scale data consisted of between one and three individual measurements per day.

3.2.6 Data Input for the Model. Hourly average feed and hourly average effluent $\mathrm{H}_{2} \mathrm{~S}$ concentrations were used for model input values and for data used for comparison with the pilotscale model simulation outputs, respectively. An average flow of $1.7 \mathrm{~m} / \mathrm{min}(60 \mathrm{cfm})$ was used for the pilot-scale model input calibration and validation. This flow rate corresponded to a 
retention time of 7.5 seconds. A constant airflow rate of $1,246 \mathrm{~m}^{3} / \mathrm{min}(44,000 \mathrm{cfm})$ was used for the full-scale model input validation, corresponding to a retention time of 8.4 seconds.

The column temperature varied from 17 to $27^{\circ} \mathrm{C}$ over the course of the pilot calibration and from 8 to $16^{\circ} \mathrm{C}$ over the course of the pilot validation. At any time, the bed temperature was relatively uniform throughout the various bed depths. Although the bed temperature varied, average bed temperatures of 20 and $11.5^{\circ} \mathrm{C}$ were used for the calibration and validation periods, respectively, because the model software currently only allows a single constant input of temperature-dependent variables.

During and shortly after the 5-min rinse cycle, unexpectedly high effluent $\mathrm{H}_{2} \mathrm{~S}$ concentrations were measured in the pilot biofilter. This was most likely caused by two phenomena. First, a companion study (Li et al., 2002) showed that the formation of a water layer during the rinse cycle would inhibit mass transfer to the biofilm. Secondly, the influent rinse water sprayed onto the biofilter bed contained dissolved $\mathrm{H}_{2} \mathrm{~S}$, which may have been stripped from the solution after passing through the spray nozzle. $\mathrm{H}_{2} \mathrm{~S}$ stripping was confirmed by shaking a sample bottle of unused rinse water feed and measuring high $\mathrm{H}_{2} \mathrm{~S}$ concentrations (up to $36 \mathrm{ppm}_{\mathrm{v}}$ ) in the sample bottle headspace. Because this flashing occurred in the headspace directly above the lava rock, it never came into contact with the biofilm; thus, effluent data obtained during the rinse cycle were excluded. Exclusion of these data also allowed the authors to maintain the assumption that the Biofilter ${ }^{\mathrm{TM}}$ two-phase model would describe the biofilter conditions.

3.2.7 Model Calibration and Validation. The Biofilter ${ }^{\mathrm{TM}}$ two-phase (solid-gas) model was used for this study. Because the actual water content in the biofilters was small (except during the 5-minute rinse cycle when the data were excluded), the two-phase model would 
describe the biofilter conditions for most of the time (Hautakangas et al., 1999 and Li et al., 2002). The model calibration was achieved by minimizing the value of an objective function and by minimizing the sum of the residuals. The objective function used for the model calibration criteria was:

$$
\mathrm{OF}=\sqrt{\frac{1}{n-1} \sum_{i=1}^{n}\left(\frac{C_{\mathrm{data,i}}-C_{\text {model }, \mathrm{i}}}{C_{\mathrm{data}, \mathrm{i}}}\right)^{2}}
$$

Where

$$
\begin{aligned}
\mathrm{OF} & =\text { objective function }, \\
\mathrm{n} & =\text { number of measured data points }, \\
\mathrm{C}_{\text {data }} & =\text { measured effluent concentration, and } \\
\mathrm{C}_{\text {model }} & =\text { model output effluent concentration } .
\end{aligned}
$$

It was not possible to obtain low values for the objective function because a small error within the low concentration range $\left(<1.0 \mathrm{ppm}_{\mathrm{v}}\right)$ resulted in large values of the OF. However, it was possible to minimize the sum of the residuals close to zero so that the errors were randomly distributed. The sum of the residuals is defined as follows:

$$
\sum_{i=1}^{n} \frac{C_{\text {data, } \mathrm{i}}-C_{\text {model }, \mathrm{i}}}{C_{\text {model }, \mathrm{i}}}
$$

According to the model sensitivity analysis ( $\mathrm{Li}$ et al., 2002), the effluent concentration was sensitive to the biofilm diffusivity and the biological kinetic parameters. The values of these parameters were adjusted within the corresponding variation ranges ( $\mathrm{Li}$ et al., 2002) to minimize the value of the objective function and to obtain a sum of the residuals close to zero for the calibration period.

For modeling, the biofilm was assumed to be homogenous and a thickness of the biofilm was chosen to ensure that all of the active biofilm was considered. This assumed thickness is not 
the actual biofilm thickness, per se, because the actual biofilm contains active and inactive biomass and the substrate concentration and system dynamics determine both the active biofilm thickness and the active biomass concentration gradient in the biofilm as function of time. This assumption may have underestimated the mass transport from the bulk phase to the biofilm. Gjaltema et al. (1994) pointed out that biofilm inhomogeneity can increase the contact area between the bulk phase and the biofilm, and a rough surface can also improve external and internal mass transfer. As a result, the biofilm inhomogeneity may have significantly influenced the overall rate of removal, and this is reflected in the model parameters that were determined from model calibration.

The biological, physical, and mass transfer model parameters that were determined for the calibration period at $20^{\circ} \mathrm{C}$ were corrected to the actual biofilter temperature for the validation periods. The maximum specific biomass growth rate $\left(\mu_{\max }\right)$ was corrected using the Arrhenius relationship with coefficients reported by Shinabe et al. (1995). Because there is no general consensus on the temperature effect on the Monod half-saturation constant $\left(\mathrm{K}_{\mathrm{s}}\right)$, it was assumed to be constant over the temperature range in this study (Grady et. al., 1999). The Henry's constant $(H)$ was corrected for temperature with a van't Hoff-type equation using the temperature correction factors provided by Montgomery (1985). The diffusivity of $\mathrm{H}_{2} \mathrm{~S}$ in the biofilm $\left(D_{b}\right)$ was adjusted to fit the data during the calibration. Because $D_{b}$ was assumed to be directly proportional to the diffusivity of $\mathrm{H}_{2} \mathrm{~S}$ in water (Fan et. al., 1990), it was corrected for temperature using the Hayduk and Laudie (1974) correlation. Although the gas-biofilm mass transfer coefficient was expected to change with temperature, the change was neglected because the model output was not found to be sensitive to the gas-biofilm mass transfer coefficient (Li et al., 2002) over the experimental temperature range used in this study. 


\subsection{RESULTS AND DISCUSSION}

3.3.1 Model Calibration. When the initial default parameter values were used for the calibration period, the model predicted much higher effluent concentrations than the actual effluent concentrations. $D_{b}$ and $\mu_{\max }$ were adjusted to maintain the sum of the residuals close to zero. In addition, the biological parameters, $K_{S}$ and $Y$ (biomass yield coefficient), were optimized by minimizing the value of the objective function. The initial default parameter values and those for the final calibration are listed in Table 3.1.

Table 3.1 — Values of Parameters Used for Model Calibration and Validation.

\begin{tabular}{|c|c|c|c|c|c|}
\hline Parameter & Symbol & $\begin{array}{l}\text { Default } \\
\text { Values }\end{array}$ & $\begin{array}{l}\text { Pilot-Scale } \\
\text { Calibration } \\
\text { Values }\left(20^{\circ} \mathrm{C}\right)\end{array}$ & $\begin{array}{c}\text { Pilot-Scale } \\
\text { Validation } \\
\text { Values }\left(11.5^{\circ} \mathrm{C}\right)\end{array}$ & $\begin{array}{c}\text { Full-Scale } \\
\text { Validation } \\
\text { Values }\left(25^{\circ} \mathrm{C}\right)\end{array}$ \\
\hline Biofilm diffusivity & $D_{b}\left(\mathrm{~cm}^{2} / \mathrm{s}\right)$ & $3.69 \times 10^{-6}$ & $4.65 \times 10^{-6}$ & $3.60 \times 10^{-6}$ & $5.30 \times 10^{-6}$ \\
\hline $\begin{array}{l}\text { Maximum specific } \\
\text { biomass growth } \\
\text { rate }\end{array}$ & $\mu_{\max }(1 / \mathrm{hr})$ & 0.20 & 0.28 & 0.066 & 0.58 \\
\hline $\begin{array}{l}\text { Biomass yield } \\
\text { coefficient }\end{array}$ & $Y(g$ cells $/ \mathrm{mol} \mathrm{S})$ & 5.6 & 3.8 & 3.8 & 3.8 \\
\hline $\begin{array}{l}\text { Monod half } \\
\text { saturation } \\
\text { coefficient }\end{array}$ & $\mathrm{K}_{\mathrm{s}}(\mu \mathrm{mol} / \mathrm{L})$ & 4.8 & 3.5 & 3.5 & 3.5 \\
\hline Henry's Constant & $\begin{array}{c}\mathrm{H} \\
\text { (dimensionless) }\end{array}$ & 0.379 & 0.379 & 0.313 & 0.420 \\
\hline
\end{tabular}

Figure 3.2 compares the effluent $\mathrm{H}_{2} \mathrm{~S}$ pilot-scale data to the model simulations for the calibration period. Figure 3.2 also shows the influent $\mathrm{H}_{2} \mathrm{~S}$ concentration initially increasing from 50 to $250 \mathrm{ppm}_{\mathrm{v}}$, and then varying from approximately 100 to $200 \mathrm{ppm}_{\mathrm{v}}$. In this "best fit" case, the objective function was minimized to 0.42 , signifying that approximately two-thirds of the 
measured data fell within $42 \%$ of the model output values (assuming a Gaussian distribution). The objective function of 0.42 was deemed acceptable considering that most of the measured effluent concentrations were below $1 \mathrm{ppm}_{\mathrm{v}}$ and a small error within this low concentration range $\left(<1 \mathrm{ppm}_{\mathrm{v}}\right)$ resulted in large values of the objective function. Visual inspection of the plotted residuals (not shown) showed a random distribution and the mean sum of the residuals was 0.014 .

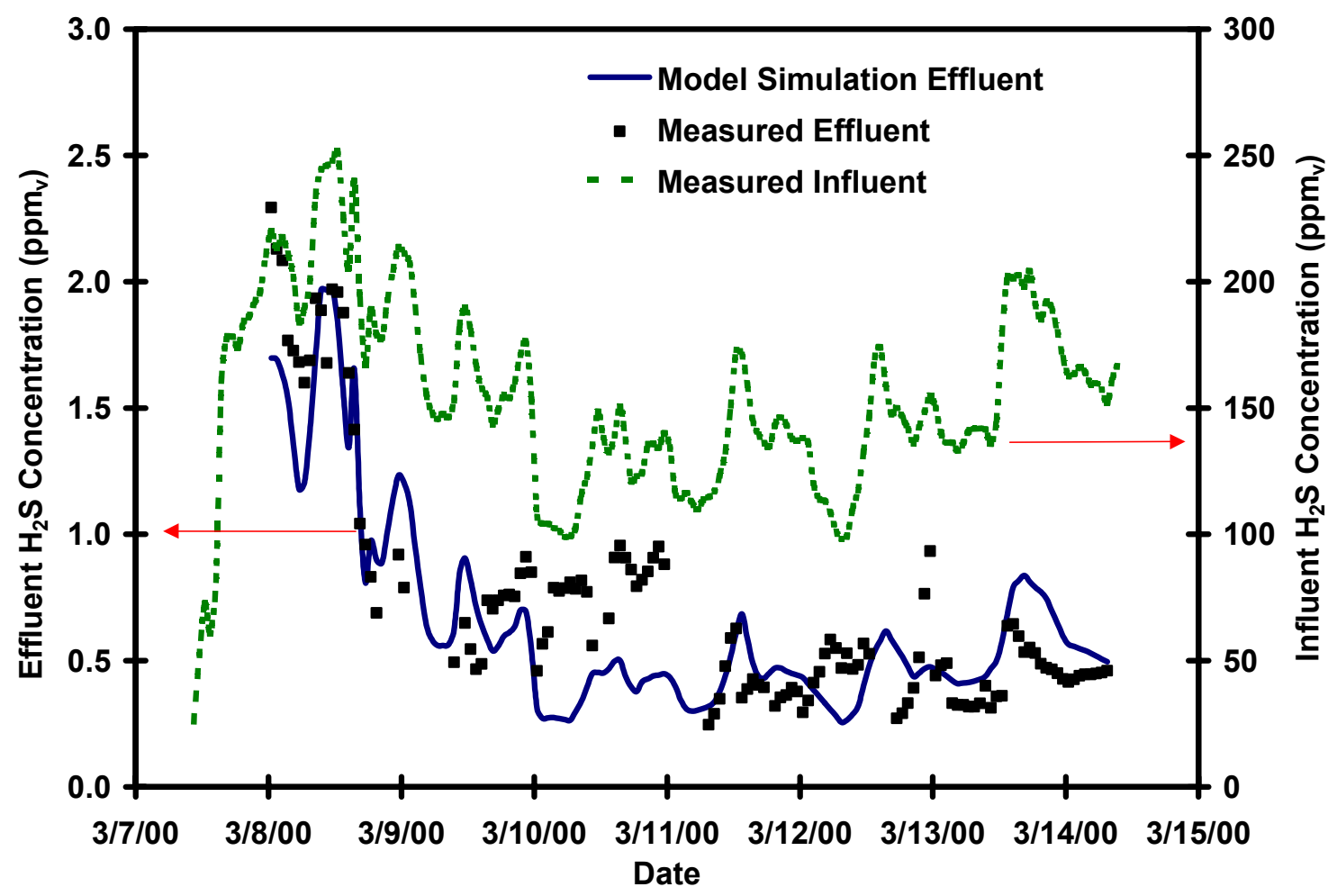

Figure 3.2-Model Simulated Effluent Concentration Compared to the Measured Effluent for the Calibration Period.

Analysis at the end of the model calibration period of one grab sample collected from the influent and effluent air indicated the following removal of other odor causing chemicals: $98 \%$ 
removal of $3.13 \mathrm{ppm}_{\mathrm{v}}$ methyl mercaptan, $98 \%$ removal of $0.12 \mathrm{ppm}_{\mathrm{v}}$ dimethyl disulfide, $58 \%$ removal of $1.25 \mathrm{ppm}_{\mathrm{v}}$ carbonyl sulfide, and $38 \%$ removal of $0.63 \mathrm{ppm}_{\mathrm{v}}$ dimethyl sulfide.

Analysis of several 24-hour composite rinse water samples collected during the calibration period indicated that the rinse water $\mathrm{pH}$ decreased from the top of the column to the bottom. The average rinse water $\mathrm{pH}$ was 7.2 in the feed and 1.9 in the sump effluent. The average sulfate concentration in the rinse water increased from approximately $500 \mathrm{mg} / \mathrm{L}$ in the feed to $3,000 \mathrm{mg} / \mathrm{L}$ in the sump effluent, indicating oxidation of $\mathrm{H}_{2} \mathrm{~S}$ and removal of the accumulated sulfate. Removal of the oxidation product, sulfate, was important because Yang and Allen (1994) found that sulfur accumulation above $40 \mathrm{mg} \mathrm{S/g}$ bed packing (dry weight) inhibited sulfide oxidation for various compost packing materials.

3.3.2 Model Validation. Figure 3.3 shows the model-predicted effluent concentration and actual data for the pilot-plant validation period. These data were obtained at a lower average temperature $\left(11.5^{\circ} \mathrm{C}\right)$ than the pilot-scale calibration period $\left(20^{\circ} \mathrm{C}\right)$. Accordingly, certain model input parameters $\left(D_{b}, \mu_{\max }\right.$, and $\left.H\right)$ were adjusted for the lower temperature (Table 1). The objective function was 0.61 and the mean sum of the residuals was -0.016 . One interesting feature was that the model predicted the decrease in effluent $\mathrm{H}_{2} \mathrm{~S}$ concentration that was observed during start up of the pilot-scale study.

When the model was initially validated to the full-scale validation data set, the measured effluent $\mathrm{H}_{2} \mathrm{~S}$ concentrations (approximately 0.1-1.4 $\mathrm{ppm}_{\mathrm{v}}$ ) from the full-scale biofilter were slightly higher than the model predictions (approximately $0.1-0.5 \mathrm{ppm}_{\mathrm{v}}$ ). Several explanations were examined to explain this occurrence. One possible explanation for the slightly lower concentration predicted by the model is that there may have been air-flow channeling in the fullscale biofilter that would be far more prevalent in a large rectangular bed than in the small 
cylindrical column used for the pilot study. Running the model assuming channeling (by decreasing the bed volume by $40 \%$ ) resulted in a model output that fit the measured effluent concentrations (results not shown). However, smoke tests indicated that there was no significant air channeling occurring in the field.

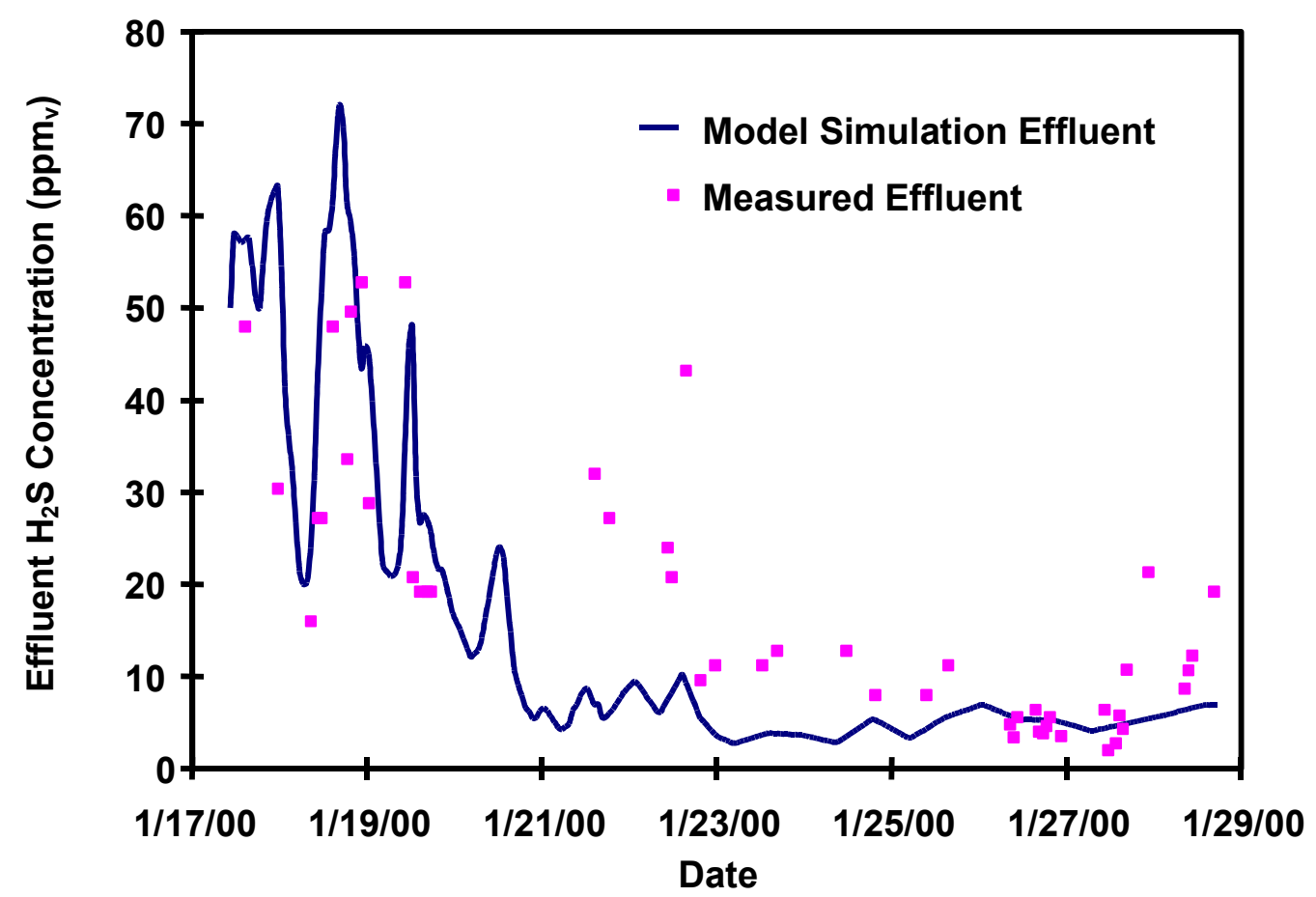

Figure 3.3-Model Simulated Effluent Concentration Compared to the Measured Effluent for the Pilot-Scale Validation Period.

Another explanation for the lower model predictions is the presence of small "dead zones" of activity in the biofilter bed having either poor removal or no removal at all. This phenomenon has been observed by Webster et al. (1999). Reasons for these "dead zones" could be poor microbial growth or microbial inhibition caused by nonuniform rinse water coverage or nonoptimal $\mathrm{pH}$. Accordingly, dead zones were considered by assuming that a specified fraction of the biofilter bed (a depth cross-section) provided no removal and the remainder of the bed 
achieved the removal predicted by the model. The resulting effluent was calculated using a volumetric weighted-average of the effluent of the active and inactive bed fractions.

Figure 3.4 shows the actual measured data compared to the model output for an assumed $1.0 \%$ inactive bed fraction. The fit to the low concentration effluent data visually appears to be good, and the objective function was 0.80 . A plot of the residuals showed they were randomly distributed (figure not shown) and the mean sum of the residuals was -0.0067 . While this does not conclusively prove there were dead zones within the full-scale biofilter, it does demonstrate the importance of ensuring that design and operation of biofilters result in a system that maximizes the biologically active zones. This may be more significant in biofilters that use organic media (e.g., compost or wood chips) that are less uniform and more prone to drying than the lava rock employed at the Cedar Rapids WPCF.

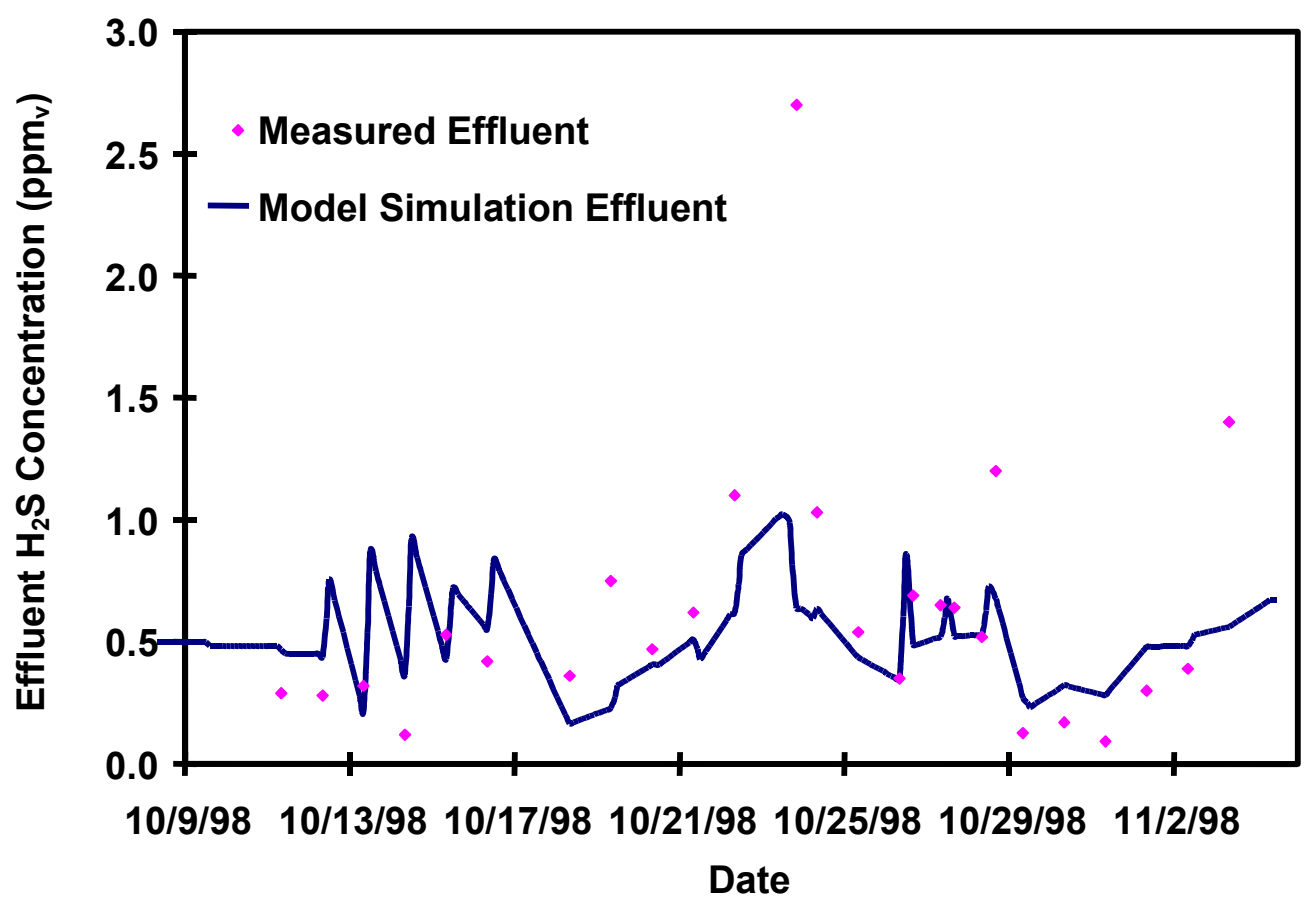

Figure 3.4-Model Simulated Effluent Concentration Compared to the Measured Effluent for the Full-Scale Validation Period Assuming 1.0\% of the Bed Is Inactive. 
Figure 3.4 also shows that, in several instances, the model predicted slightly lower effluent concentrations than the measured values, especially during the middle of the validation period. For the full-scale validation period, the average exhaust air temperature of $25^{\circ} \mathrm{C}$ was used even though the temperature varied from $22.2^{\circ} \mathrm{C}$ to $28.9^{\circ} \mathrm{C}$. The values for the model input parameters $\left(D_{b}, \mu_{\max }\right.$, and $\left.H\right)$ were corrected for temperature (see Table 1). Considering that the validation was conducted at a much lower temperature than the calibration, the temperature varied greatly, and the empirical correlations used for the temperature corrections were not perfect, the model predictions were reasonably good.

The model calibration and validation also show the importance of proper selection of packing material. The ideal packing material should have a high specific surface area to support biological growth, be able to store water and make it readily available during periods of drying, and also hold up well under extreme conditions (e.g., low pH, varying humidity, and compaction) encountered in a biofilter. At Cedar Rapids WPCF, the lava rock appeared to be holding up well under the very acidic conditions ( $\mathrm{pH}$ approximately 2 in sump effluent). The lava rock also has an enhanced surface area for the biofilm to colonize because of open pores on the rock particle surface. In addition, mercury porosimetry (performed by the Analytical Testing Services Division of Porous Materials, Inc., Ithaca, New York) showed that the median pore diameter was $58 \mu \mathrm{m}$ and capillary rise calculations (Franzin and Finnemore, 1997) indicated that the lava rock pores were able to hold water that could possibly be stored for microbial growth. Morton and Caballero (1996) also reported that porous rock performed much better than plastic packing material.

To optimize $\mathrm{H}_{2} \mathrm{~S}$ removal efficiency, it is important to understand the microbial ecology in a biofilter. Although most attention has been paid to Thiobacillus thiooxidans (Lizama and 
Sankey, 1993; Shinabe et al., 1995; Kurosawa, et al., 1993; and Konishi et al., 1995), other species of Thiobacillus were reported to oxidize sulfide. For example, Kelly (1982) reported members of the genus Thiobacillus, including denitrificans, neapolitanus, thioparus, novellus, and ferrooxidans. In addition, Janssen et al. (1995) and Comas et al. (1999) reported a mixed culture of Thiobacillus in a sulfide-oxidizing bioreactor. Although most of these organisms exhibited low growth rates and the measured cell concentrations were typically low, as well, as summarized in Table 3.2, high specific growth rate values $\left(0.1-1.0 \mathrm{hr}^{-1}\right)$ have been reported in the literature for members of Thiobacillus that utilized reduced sulfur as a substrate. Possible explanations include the high-density cultivation of sulfur-oxidizing bacteria (Kurosawa et al. 1993) or sulfide oxidation consisting of a combination of chemical and biological reactions (Janssen et al., 1995, and McNevin et al., 1999).

As part of this study, microbial analyses of the rinse water and lava rock were performed. The detailed results (not included) clearly showed that a ferrous iron-oxidizing organism was present that had the properties of Acidithiobacillus ferrooxidans. T. thiooxidans cannot oxidize ferrous iron; however, A. ferrooxidans can oxidize reduced sulfur compounds (Kelly and Wood, 2000). It is possible that the Cedar Rapids WPCF biofilter had a mixed culture consisting of an iron oxidizer and a sulfur oxidizer; however, the development of the expected number of colonies based on total cell number when ferrous-grown cells were incubated under $\mathrm{H}_{2} \mathrm{~S}$ argued against that possibility. Accordingly, it was concluded that the study had one dominant organism that was an iron oxidizer that was also able to oxidize reduced sulfur.

3.3.3 Model Applications. One purpose of the model calibration and validations was to obtain values for the model parameters so the model could be used as a tool for biofilter design and operation. The usefulness of the model has been demonstrated with several examples. The 
relationship that gas residence time, influent concentration, temperature, and dynamic loading have on biofilter performance and design are discussed here.

Table 3.2-Values of Biokinetic Parameters for Thiobacillus Reported in Recent Literature.

\begin{tabular}{|c|c|c|c|c|c|}
\hline Source & Strain & $\begin{array}{c}\text { T (K) } \\
\text { Range }\end{array}$ & Parameter & Substrate & Value (units) \\
\hline \multirow{2}{*}{$\begin{array}{c}\text { Shinabe et al. } \\
1995\end{array}$} & \multirow{2}{*}{ Thiooxidans KSI } & \multirow{2}{*}{$283-303$} & $\mathrm{~V}_{\mathrm{m}}$ & \multirow{2}{*}{$\mathrm{H}_{2} \mathrm{~S}$} & 2.0-2.8 ( $\mu \mathrm{mol} / \mathrm{min}$-cell $)$ \\
\hline & & & $\mathrm{K}_{\mathrm{S}}$ & & $44\left(\mathrm{ppm}_{\mathrm{v}}\right)$ \\
\hline \multirow{2}{*}{$\begin{array}{l}\text { Hirai et al. } \\
1990\end{array}$} & \multirow{2}{*}{ Night soil sludge } & \multirow{2}{*}{$\mathrm{N} / \mathrm{A}$} & $\mathrm{V}_{\mathrm{m}}$ & \multirow{2}{*}{$\mathrm{H}_{2} \mathrm{~S}$} & $5.0(\mathrm{~g}-\mathrm{S} /[$ day $\cdot \mathrm{kg}$-dry peat] $)$ \\
\hline & & & $\mathrm{K}_{\mathrm{S}}$ & & $55\left(\mathrm{ppm}_{\mathrm{v}}\right)$ \\
\hline $\begin{array}{l}\text { Buisman et } \\
\text { al. } 1991\end{array}$ & Mixed culture & 293 & Y & $\mathrm{H}_{2} \mathrm{~S}$ & 5.6 (g-cells/mol-S) \\
\hline $\begin{array}{c}\text { Kurosawa et } \\
\text { al. } 1993\end{array}$ & $\begin{array}{c}\text { Thiooxidans JCM } \\
7814\end{array}$ & $N / A$ & $\mu$ & $\begin{array}{c}\mathrm{S}_{2} \mathrm{O}_{3} \\
\text { (thiosulfate) }\end{array}$ & $0.11-0.14(1 / \mathrm{hr})$ \\
\hline $\begin{array}{c}\text { Janssen et al. } \\
1995\end{array}$ & Mixed culture & 296 & $\mu$ & $\mathrm{H}_{2} \mathrm{~S}$ & $0.87(1 / \mathrm{hr})$ \\
\hline \multirow{2}{*}{$\begin{array}{c}\text { Konishi et al. } \\
1995\end{array}$} & \multirow{2}{*}{ Thiooxidans } & \multirow{2}{*}{303} & $\mu$ & \multirow{2}{*}{$\begin{array}{c}\mathrm{S} \\
\text { (elemental) }\end{array}$} & $0.11(1 / \mathrm{hr})$ \\
\hline & & & Y & & $2.05 \times 10^{11}$ (cells/g-S) \\
\hline \multirow{2}{*}{$\begin{array}{c}\text { Comas et al. } \\
1999\end{array}$} & \multirow{2}{*}{ Mixed culture } & \multirow{2}{*}{$\mathrm{N} / \mathrm{A}$} & $\mu$ & \multirow{2}{*}{$\mathrm{H}_{2} \mathrm{~S}$} & $1.0(1 / \mathrm{hr})$ \\
\hline & & & $\mathrm{K}_{\mathrm{S}}$ & & 28.8 (mg/L) \\
\hline
\end{tabular}

3.3.3.1 Effect of Residence Time on $\mathrm{H}_{2} \mathrm{~S}$ Removal. The effect of gas residence time on $\mathrm{H}_{2} \mathrm{~S}$ removal has been experimentally studied by other researchers (Yang and Allen, 1994, and Chung et al., 1996). The residence time $(\tau)$ is defined as follows: 


$$
\tau=\frac{\varepsilon V}{Q}
$$

Where

$$
\begin{aligned}
& \mathrm{Q}=\text { gas flow rate, } \\
& \varepsilon=\text { bed porosity, and } \\
& \mathrm{V}=\text { bed volume. }
\end{aligned}
$$

Figure 3.5 shows the model's predicted effluent concentration as a function of residence time using the Cedar Rapids WPCF model parameters and the full-scale biofilter bed dimensions and lava rock properties for a constant influent concentration of $100 \mathrm{ppm}_{\mathrm{v}}$. Because the bed dimensions remained constant, residence time was decreased by increasing the airflow rate. As expected, decreasing the residence time increases the effluent concentration. Figure 3.5 also shows that, for a constant influent concentration of $100 \mathrm{ppm}_{\mathrm{v}}$ the Cedar Rapids WPCF should provide at least 5 seconds of residence time to achieve a treatment objective of $0.5 \mathrm{ppm}_{\mathrm{v}}$ (Dechant et al., 1999). This minimum residence time is also a function of the influent concentration and temperature, as discussed in the following sections.

3.3.3.2 Effect of the Influent Concentration on $\mathrm{H}_{2} \mathrm{~S}$ Removal. Biofilters have sometimes been designed based on the relationship between the residence time and the sulfur-loading rate (e.g., e Schowengerdt et al. [1999]). These applications assume that, with a constant residence time, equal sulfur loading rates will achieve the same percent removal.

However, the model simulations in this study indicated that two equal influent sulfur loading rates (with different influent concentrations and airflow rates) to two different biofilters having equal residence times may not result in equal removal efficiencies (data not shown). At the same time, the model simulations indicated that when the influent concentrations are equal (but with different airflow rates) and the residence times are equal, the biofilter's effluent 
concentrations are the same (data not shown). Therefore, it may be appropriate to consider the influent concentration in biofilter design. Figure 3.6 demonstrates this for operation temperatures of 15,20 , and $25^{\circ} \mathrm{C}$ using the Cedar Rapids WPCF temperature-corrected model parameters and the full-scale biofilter bed dimensions and lava rock properties. Figure 3.6 further shows that the minimum residence time required to achieve a treatment objective of $0.5 \mathrm{ppm}_{\mathrm{v}}$ depends on the influent concentration. The effect is most dramatic at influent concentrations below $100 \mathrm{ppm}_{\mathrm{v}}$, and especially at the lower temperature of $15^{\circ} \mathrm{C}$. This type of plot also would allow a facility to determine whether an existing biofilter can accept higher influent concentrations (requiring a higher minimum residence time) or an increase in flow rate (resulting in a decreased residence time).

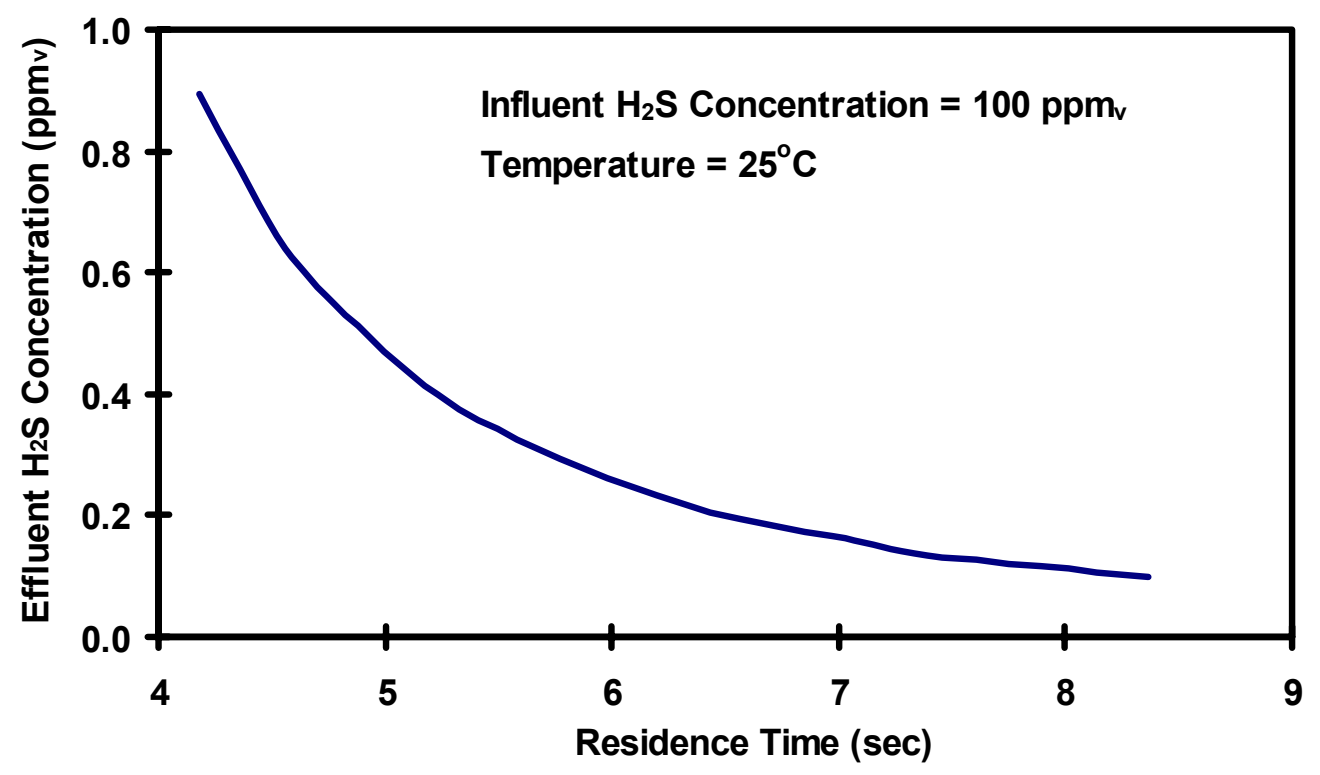

Figure 3.5-Model Simulations Showing Effluent Concentration as a Function of Residence Time. 


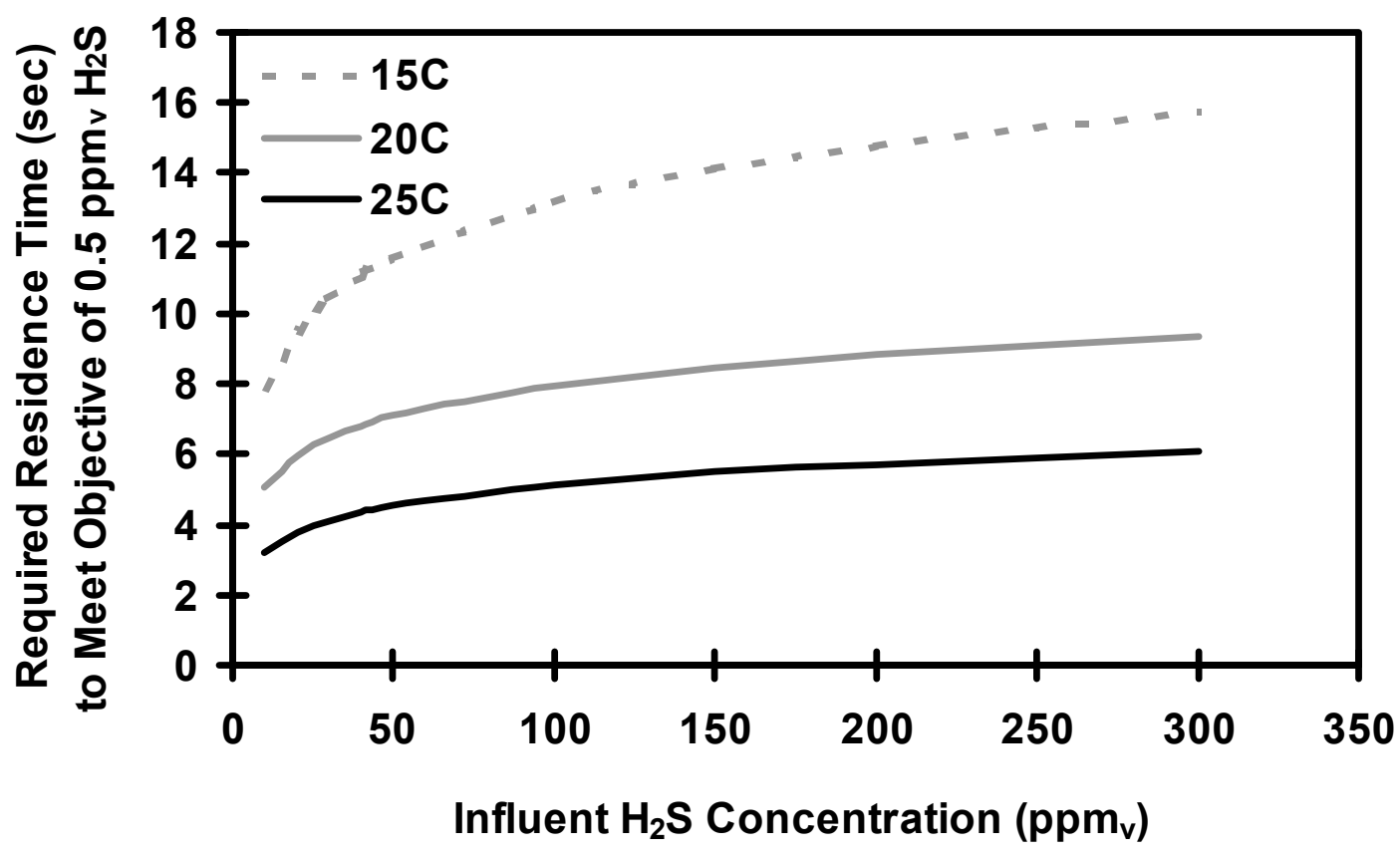

Figure 3.6- Model Simulations Showing Minimum Residence Time Required to Achieve a Treatment Objective of $\mathbf{0 . 5} \mathbf{p p m}_{\mathrm{v}}$ as a Function of Influent Concentration.

3.3.3.3 Effect of Temperature on $\mathrm{H}_{2} \mathrm{~S}$ Removal. Figure 3.6 also demonstrates that a biofilter will achieve greater removal at higher temperatures, which may explain why some biofilters do not achieve treatment objectives during cooler months. Temperature can have a significant influence on the minimum residence time required to meet a specific treatment objective. The temperature also has an influence on the time required to reach a stable effluent concentration during biofilter start-up. The model-generated curves in Figure 3.7 show the effluent $\mathrm{H}_{2} \mathrm{~S}$ concentration during the start-up period using the Cedar Rapids WPCF temperaturecorrected model parameters and the full-scale biofilter bed dimensions and lava rock properties. Figure 3.7 also shows that the time the biofilter takes to achieve the steady-state treatment objective of $0.5 \mathrm{ppm}_{\mathrm{v}}$ increases from less than 1 day to 2 to 3 days as the temperature is decreased from 25 to $15^{\circ} \mathrm{C}$. Accordingly, Laustsen et al. (1999) recommended the influent air 
stream be heated in colder months if the influent air stream temperature is low. Although $\mathrm{H}_{2} \mathrm{~S}$ removal increases with increasing temperature, removal will actually decrease at temperatures greater than the microorganisms' optimum temperature. Chung et al. (1996) found that the optimum temperature for removal of $\mathrm{H}_{2} \mathrm{~S}$ using a biofilter was $30^{\circ} \mathrm{C}$, decreasing to approximately $65 \%$ of this rate at $50^{\circ} \mathrm{C}$.

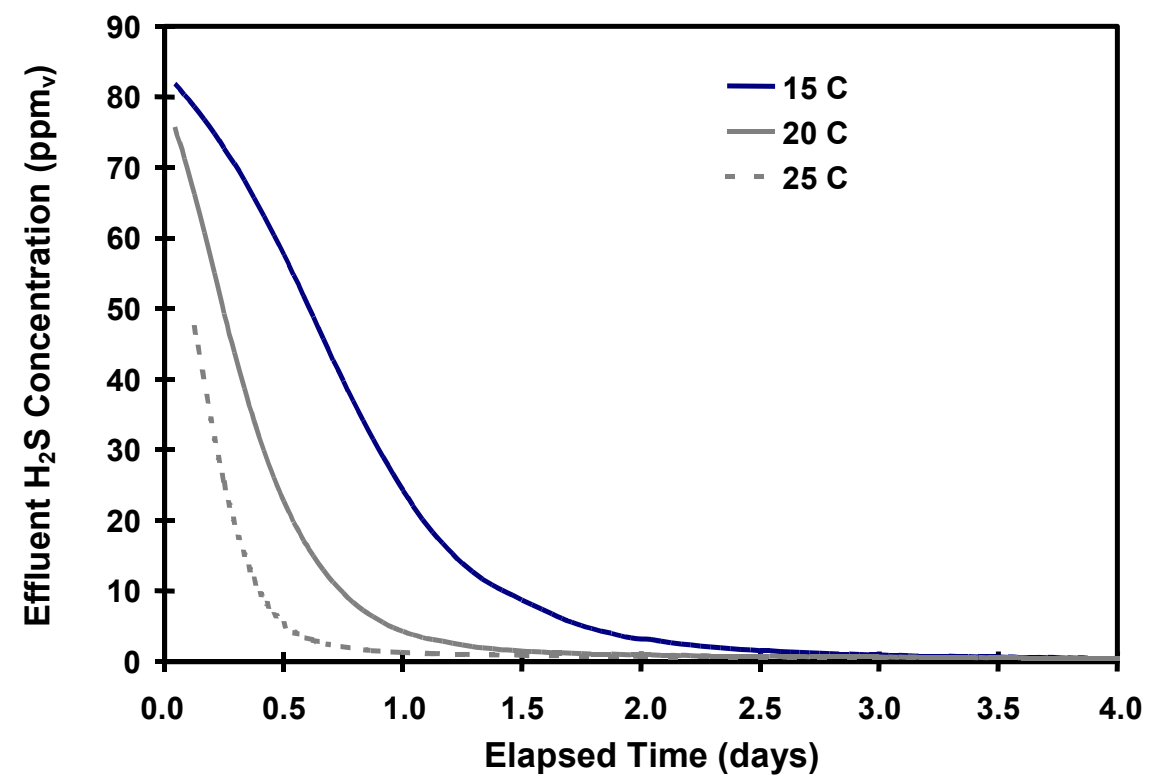

Figure 3.7-Model Simulations Showing Start-Up Period for Various Temperatures.

3.3.3.4 Design Criteria for Biofilters. The model calibration period also highlights the need to consider the maximum influent concentration instead of the average influent concentration when sizing a biofilter. Figure 3.2 shows that, after the large increase in the influent $\mathrm{H}_{2} \mathrm{~S}$ concentration (from 50 to $250 \mathrm{ppm}_{\mathrm{v}}$ ) the initially high effluent $\mathrm{H}_{2} \mathrm{~S}$ concentration (about $2 \mathrm{ppm}_{\mathrm{v}}$ ) quickly drops to less than $1 \mathrm{ppm}_{\mathrm{v}}$. To address this issue, Biofilter ${ }^{\mathrm{TM}}$ was run using the Cedar Rapids WPCF model parameters and the full-scale biofilter bed dimensions and lava rock properties at $25^{\circ} \mathrm{C}$, with a dynamic increase in the influent $\mathrm{H}_{2} \mathrm{~S}$ concentration for two 
scenarios. The first scenario used the required residence time to meet the treatment objective $(0.5$ $\operatorname{ppm}_{v} \mathrm{H}_{2} \mathrm{~S}$ ) based on the average influent concentration and the second scenario used the required residence time based on the maximum influent concentration.

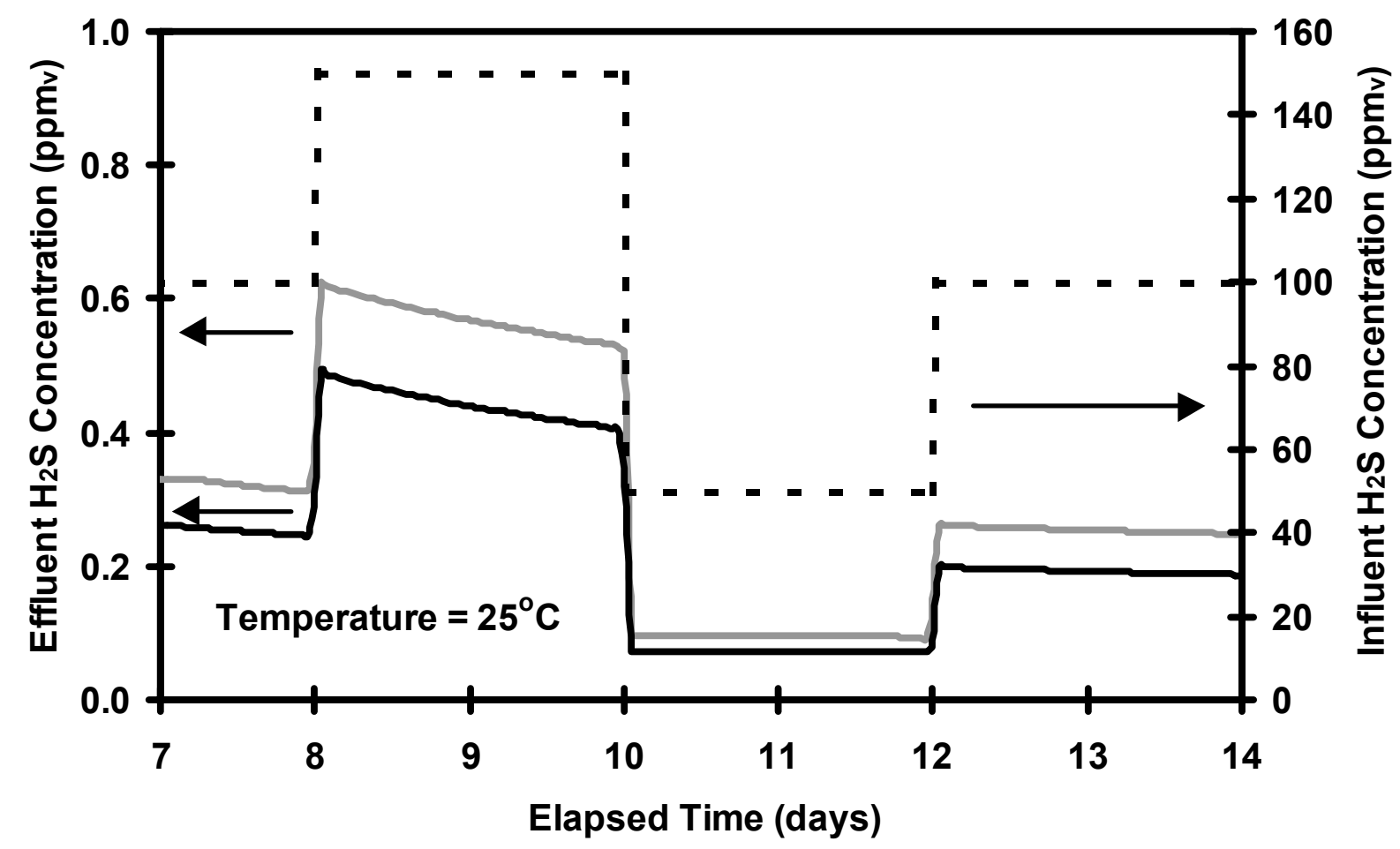

Figure 3.8 -- Biofilter ${ }^{\mathrm{TM}}$ Simulations Showing the Effect of Influent Concentration Step Changes on Biofilter Performance Based on the Full-scale Cedar Rapids WPCF Biofilter Bed Size: The Gray Line is the Model Simulated Effluent Concentration Using a Residence Time of 5.1 Seconds (Required to Achieve 0.5 ppmv Effluent for 100 ppmv Influent Concentration). The Black Line Is the Model Simulated Effluent Concentration Using a Residence Time of 5.5 Seconds Determined (Necessary to Achieve 0.5 ppmv Effluent for 150 ppmv Influent Concentration), and the Dashed Line Is the Influent Concentration.

Figure 3.8 shows that the influent $\mathrm{H}_{2} \mathrm{~S}$ concentration was maintained at a constant 100 $\mathrm{ppm}_{\mathrm{v}}$ for the first 8 days, stepped up to $150 \mathrm{ppm}_{\mathrm{v}}$ for two days on day 8 , stepped down to 50 $\mathrm{ppm}_{\mathrm{v}}$ for two days on day 10 , and returned to $100 \mathrm{ppm}_{\mathrm{v}}$ for the final two days on day 12 . The 
model-predicted effluent concentrations for the two scenarios in response to this change in influent concentration are shown in Figure 3.8. Residence times of 5.1 and 5.5 seconds required to meet the treatment objective for the average $\left(100 \mathrm{ppm}_{\mathrm{v}}\right)$ and maximum $\left(150 \mathrm{ppm}_{\mathrm{v}}\right)$ influent concentrations, respectively, were determined from Figure 3.6. The dynamic responses of the biofilter shown in Figure 3.8 indicate that the biofilter always met the treatment objective for the residence time based on the maximum influent concentration, but failed to meet the treatment objective based for the residence time based on the average influent concentration during days 8 to 10 .

\subsection{CONCLUSIONS}

1. In this study, a model used for predicting the removal of gaseous $\mathrm{H}_{2} \mathrm{~S}$ in biofilters was calibrated and validated using pilot- and full-scale data obtained from the Cedar Rapids WPCF. The model calibration simulation agreed well with the actual pilot-scale data. The model validation simulations of the pilot- and full-scale biofilter also agreed well with actual data as shown by examination of the objective function mean sum of the residuals. The model used in this study has been incorporated into a user-friendly software package (called Biofilter ${ }^{\mathrm{TM}}$ ).

2. Model simulations of the full-scale biofilter using the parameters determined from the model calibration suggests that the model can predict full-scale biofilter performance and can also provide insight into the influence of gas residence time, influent concentration, temperature, and changes in influent concentration on biofilter performance and design. For example, model simulations showed that the Cedar Rapids WPCF should provide at least 5 seconds of residence time to achieve a treatment objective of $0.5 \mathrm{ppm}_{\mathrm{v}}$; the time the biofilter takes to achieve the 
steady-state treatment objective of $0.5 \mathrm{ppm}_{\mathrm{v}}$ increases from less than 1 day to 2 to 3 days as the temperature is decreased from 25 to $15^{\circ} \mathrm{C}$.

3. Biofilters have sometimes been designed based on the relationship between the residence time and the sulfur-loading rate. However, the model simulations of this study indicated that it may be appropriate to consider the influent concentration in biofilter design. Model simulations also showed the need to consider the maximum influent concentration instead of the average influent concentration when sizing a biofilter.

\subsection{ACKNOWLEDGEMENTS}

3.5.1 Credits. This research was supported by the Cedar Rapids Water Pollution Control Facilities and the National Center for Clean Industrial and Treatment Technologies (CenCITT, Michigan Technological University, Houghton). CenCITT is partially supported by a grant from the U.S. Environmental Protection Agency, Washington, D.C. For part of this project, Ron Martin, Jr. was supported as a U.S. Department of Education, Washington, D.C. Graduate Assistantship in Areas of National Need (GAANN) Ph.D. fellow. Any opinions, findings, conclusions, or recommendations expressed in this paper are those of the authors and do not necessarily reflect the view of the supporting organizations.

3.5.2 Authors. Ron Martin, Jr. and Hebi Li are enrolled in the Environmental Engineering Ph.D. program at Michigan Technological University, Houghton. John C. Crittenden is a presidential professor of civil and environmental engineering, James R. Mihelcic is a professor of civil and environmental Engineering, and Donald R. Lueking is an associate professor of biological sciences, at Michigan Technological University. Christopher R. Hatch is 
an operations specialist and Patrick Ball is the director of the Cedar Rapids Water Pollution Control Facilities. Correspondence should be addressed to John C. Crittenden, Department of Civil and Environmental Engineering, Michigan Technological University, 1400 Townsend Drive, Houghton, MI, 49931, email: jcritt@mtu.edu.

\subsection{REFERENCES}

Amanullah, A.; Farooq, S.; and Viswanathan, S. (1999) Modeling and Simulations of a Biofiter. Ind. Eng. Chem. Res., 38, 2765.

Buisman, C.J.N.; Ijspeert, P.; Hof, A.; Janssen, A.J.H.; ten Hagen, R.; and Lettinga, G. (1991) Kinetic Parameters of a Mixed Culture Oxidizing Sulfide and Sulfur with Oxygen. Biotechnol. Bioeng. 38, 813.

Chung, Y.-C.; Huang, C.; and Tseng, C.-P. (1996) Operation and Optimization of Thiobacillus thioparus CH11 Biofilter for Hydrogen Sulphide Removal. J. Biotechnol., 52, 31.

Comas, J.; Balaguer, M.; Poch, M.; and Rigola, M. (1999) Pilot Plant Evaluation for Hydrogen

Sulphide Biological Treatment: Determination of Optimal Conditions Linking Experimental and Mathematical Modelling. Environ. Technol., 20, 53.

Dechant, D.; Ball, P.; and Hatch, C. (1999) Full-Scale Validation of Emerging Bioscrubber Technology for Odor Control. Proc. Water Environ. Fed. 72nd Annu. Conf. Exposition [CDROM], New Orleans, La.

Deshusses, M.A.; Hamer, G.; and Dunn, I.J. (1995) Behavior of Biofilters for Waste Air Biotreatment. 2. Experimental Evaluation of a Dynamic Model. Environ. Sci. Technol., 29, 1059. 
Fan, L.-S.; Leyva-Ramos, R.; Wisecarver, K.D.; and Zehner, B.J. (1990) Diffusion of Phenol Through a Biofilm Grown on Activated Carbon Particles in a Draft-Tube Three-Phase FluidizedBed Bioreactor. Biotechnol. Bioeng., 35, 279.

Franzin, J.B. and Finnemore, E.J. (1997). Fluid mechanics with engineering applications (9th Ed.) McGraw-Hill, Inc. New York.

Gjaltema, A.; Arts, P.A.M.; van Loosdrencht, M.C.M.; Kuenen, J.G.; and Heijnen, J.J. (1994) Heterogeneity of Biofilms in Rotating Annular Reactors: Occurrence, Structure, and Consequences. Biotechnol. Bioeng., 44, 194.

Grady, C.P.L. Jr.; Daigger, G.T.; and Lim, H.C. (1999) Biological Wastewater Treatment. 2nd Ed. Marcel Dekker, Inc. New York.

Hautakangas, H.; Mihelcic, J.R.; Crittenden, J.C.; and Oman, E.J. (1999) Optimization and Modeling of Biofiltration for Odor Control. Proc. Water Environ. Fed. 72nd Annu. Conf. Exposition [CD-ROM], New Orleans, La.

Hayduk, W., and Laudie, H. (1974) Prediction of Diffusion Coefficients for Non-Electrolytes in Dilute Aqueous Solutions. AIChE J., 28, 611.

Hirai, M.; Ohtake, M.; and Shoda, M. (1990) Removal Kinetics of Hydrogen Sulfide, Methanethiol and Dimethyl Sulfide by Peat Biofilters. J. Ferment. Bioeng., 70, 334.

Janssen, A.J.H.; Sleyster, R.; van der Kaa, C.; Jochemsen, A.; Bontsema, J.; and Lettinga G. (1995) Biological Sulphide Oxidation in a Fed-Batch Reactor. Biotechnol. Bioeng. 47, 327.

Kelly, D.P. (1982) Biochemistry of the Chemolithotrophic Oxidation of Inorganic Sulphur. Proc. Royal Society Discussion Meeting, London, U.K. 
Kelly, D.P. and Wood, A.P. (2000) Reclassification of some species of Thiobacillus to the newly designated genera Acidithiobacillus gen. Nov., Halothiobacillus gen. Nov. and Thermithiobacillus gen. Nov. Internal. J. System. Evol. Microbiol. 50:511.

Konishi, Y.; Asai, S.; and Toshida, N. (1995) Growth Kinetics of Thiobacillus thiooxidans on the Surface of Elemental Sulfur. Appl. Environ. Microbiol. 61, 3617.

Kurosawa, H.; Konno, Y.; Nakamura, K.; and Amano, Y. (1993) Estimation of the $\mathrm{CO}_{2}$ Fixation Ability of Thiobacillus thiooxidans JCM 7814. J. Ferment. Bioeng. 75, 71.

Laustsen, T.A.; Marran, K.S.; and Little H.L. (1999) Design Parameters for a Biofilter that Successfully Treats Volatile Organic Compounds from a Combined Sewer. Proc. Water Environ. Fed. 72nd Annu. Conf. Exposition [CD-ROM], New Orleans, La.

Li, H.; Crittenden, J.C.; Mihelcic, J.R.; and Hautakangas, H. (2002) Optimization of Biofiltration for Odor Control: Model Development and Parameter Sensitivity. Water Environ. Res., 74, 5.

Lizama, H.M., and Sankey, B.M. (1993) Conversion of Hydrogen Sulphide by Acidophilic Bacteria. Appl. Microbiol. Biotechnol. 40, 438.

Montgomery, J.M. (1985) Water Treatment: Principles and Design. John Wiley \& Sons, Inc. New York.

McNevin, D.; Barford, J.; and Hage, J. (1999) Adsorption and Biological Degradation of Ammonium and Sulfide on Peat. Water Res., 33, 1449.

Morton, R., and Caballero, R. (1996) The Biotrickling Story. Water Environ. Technol., 8, 39.

Schowengerdt, R.W.; Hunter, B.; and Hanson, R.E. (1999) Incremental Hydrogen Sulfide Loading and Diurnal Fluctuation of Three Operating Biofilters. Proc. Water Environ. Fed. 72nd Annu. Conf. Exposition [CD-ROM], New Orleans, La. 
Shinabe, K.; Oketani, S.; Ochi, T.; and Matsumura, M. (1995) Characteristics of Hydrogen Sulfide Removal by Thiobacillus thiooxidans KS1 Isolated from a Carrier-Packed Biological Deodorization System. J. Ferment Bioeng., 80, 592.

van Langenhove, H.; Wuyts, E.; and Schamp N. (1986) Elimination of Hydrogen Sulphide from Odorous Air by a Wood Bark Biofilter. Water Res. 20. 1471.

Wani, A.H.; Branion, R.M.R.; and Lau A.K. (1998) Effects of Periods of Starvation and Fluctuating of Hydrogen Sulfide Concentration on Biofilter Dynamics and Performance. $J$. Hazardous Materials, 60, 287.

Webster, T.S.; Cox, H.H.J.; and Deshusses, M.A. (1999) Resolving Operational and Performance Problems Encountered in the Use of a Pilot/Full-Scale Biotrickling Filter Reactor. Env. Prog., 18, 163.

Yang, Y., and Allen, E.R. (1994) Biofiltration Control of Hydrogen Sulfide 1. Design and Operation Parameters. J. Air Waste Manage. Assoc., 44, 863.

Zarook, S.M.; Shaikh, A.A.; and Ansar, Z. (1997) Development, Experimental Validation and Dynamic Analysis of a General Transient Biofilter Model. Chem. Eng. Sci., 52, 759. 


\section{CHAPTER FOUR}

\section{A BIOFILTER DESIGN AND PERFORMANCE CHARACTERIZATION STRATEGY FOR THE CONTROL OF ODOROUS HYDROGEN SULFIDE}

\subsection{INTRODUCTION}

Because biofiltration for odor control is an emerging technology, there is limited information on the design and performance characterization of biofilters for this purpose. This study presents additional methods for designing biofilters and characterizing biofilter performance to supplement the methods cited in the existing literature.

4.1.1 Odor Control Using Biofiltration. Currently, the emission and control of odorous gases are a significant concern to the wastewater industry and they are expected to become a greater concern in the future. Many wastewater treatment plants (WWTPs) currently have, or are planning to install, odor control processes. In addition, public concern over odors is growing and regulatory limits for odor emissions are becoming more stringent. For example, the Los Angeles (California) County Sanitation Districts must control odor emissions to nondetectable levels at the plant boundary; it often costs more to remove the final $5 \%$ of odorous emissions than the first 95\% of the emissions (Morton and Caballero, 1996).

Odorous emissions can be controlled, reduced, or eliminated by implementing source control, employing treatment technology (e.g., adsorption, wet scrubbing, oxidation, precipitation, incineration), or using masking agents. However, masking agents fail to remove the odorous contaminant and physical and chemical treatment technologies typically have high operational costs. For example, wet scrubbers at the Los Angeles County Sanitation District require expensive weekly cleaning with acid to reduce carbonate scaling (Morton and Caballero, 
1996). The major disadvantage of adsorption is the cost associated with handling, regeneration, and replacement of an adsorbent such as activated carbon. Biofiltration can provide a safe and effective method of odor removal, achieving effluent concentrations comparable to that of scrubbing or adsorption, but at a lower operational cost. Additionally, biofiltration is considered an environmentally friendly or "green technology" because it requires no chemical addition and does not produce harmful waste streams or byproducts.

Recent Water Environment Federation Technical Exposition and Conferences

(WEFTECs, New Orleans, LA, 1999; Anaheim, CA, 2000; and Chicago, IL, 2002) have devoted a significant amount of time to the control of odor and volatile organic compounds (VOCs). Water Environment Federation has also held specialty conferences devoted entirely to the control of odor and VOC emissions (Houston, TX 1997; Cincinnati, OH, 2000; and Albuquerque, NM, 2002). Several of the presentations specifically demonstrated the cost effectiveness of biofiltration for odor control (e.g., Dechant et al., 1999; Wong et al., 1999; Sorensen et al., 2000). Morton and Caballero (1996) estimated that operating costs for a biofiltration unit would be $80 \%$ lower than traditional wet scrubbers and the payback on the higher capital cost for a 28.3 $\mathrm{m}^{3} / \mathrm{min}$ biofiltration unit would be 2 years. Vaith et al. (1996) stated that compared to wet scrubbing technologies using packed towers and mist scrubbing, "biofiltration was the most economical on a present worth basis."

Over the past several years, many advances have been made in biofiltration for removal of organic air emissions such as methanol, methyl tert-butyl ether (MTBE), and toluene (Shareefdeen et al., 1993; Fortin and Deshusses, 1999a \& 1999b; Cox and Deshusses, 1999). Swanson and Loehr (1997) provide an overview of design and operation principles of biofiltration applied to VOC removal and the June 1997 edition of Journal of Environmental 
Engineering is devoted to biofiltration of VOCs. In addition, Wallis et al. (1996) have critically reviewed literature on reducing air toxics (e.g., VOCs) and ozone precursor emissions at wastewater plants; however, there is little mention of odor control. A recent Water Environment Research Foundation report, Biofiltration: Controlling Air Emissions through Innovative Technology by Torres et al. (1997) has useful information to size biofilters to meet acceptable removal rates based on pilot-scale retention times; however, the focus is on the treatment of VOCs. The Fall 1999 edition of Environmental Progress is devoted to full-scale biofilters and Devinny et al. (1999) published a book on biofiltration for air pollution control; although there is some information on the control of odorous $\mathrm{H}_{2} \mathrm{~S}$, both of these sources focus on VOCs.

\subsubsection{Design and Optimization of Biofilters for Control of Odorous $\mathrm{H}_{2} \mathrm{~S}$. Although}

biofilters have been widely studied and their use for odor control is promising, the biofiltration processes for $\mathrm{H}_{2} \mathrm{~S}$ removal are not as well understood when compared to more established airtreatment technologies such as scrubbing. Moreover, our understanding of the fundamental biological processes that drive sulfide oxidation is less refined than our knowledge of how biochemical oxygen demand (BOD), nitrogen, and phosphorous are removed in conventional wastewater treatment processes. Thus, there is scant methodology and guidance for the design, optimization, and operation of biofilters used for $\mathrm{H}_{2} \mathrm{~S}$ removal. Biofiltration for odor control is a "developing technology" that currently requires "pilot testing" and "flexible design" (Vaith et al., 1996).

Current biofilter design and operation practices for $\mathrm{H}_{2} \mathrm{~S}$ removal are limited. For example, Schowengerdt et al. (1999), provide several sets of performance curves for $99 \%$ removal efficiency that are based on influent air flow and influent $\mathrm{H}_{2} \mathrm{~S}$ concentration. System performance expressed as elimination capacity or removal efficiency is typically evaluated as a 
function of sulfur loading rates or residence times. Morton and Caballero (1996) show the removal efficiency as a function of $\mathrm{H}_{2} \mathrm{~S}$ loading based on actual data, but the data are poorly correlated. Yang and Allen provide a plot of removal efficiency as a function of retention time, but this is based on measured data for a specific operating condition. Chitwood and Devinney (2001) show the removal efficiency of $\mathrm{H}_{2} \mathrm{~S}$ as a linear function of temperature using actual data from a lava rock biofilter $\left(\mathrm{H}_{2} \mathrm{~S}\right)$.

While these methods demonstrate how performance may drop with increased loading, decreased residence time, and decreasing temperature, they provide only partial information for the design and/or operation of a biofilter. Other key process design and operation parameters such as packing material size, influent concentration, and dynamic loading changes will significantly influence biofilter performance. Modeling can account for these parameters as well as provide better correlated relationships for temperature, removal efficiency, and other performance characteristics such as effluent concentration.

Modeling is one of several important steps in the design of a biofilter. Devinny et al. (1999 pp. 143-144) point out that an ideal biofilter design strategy includes preliminary analysis to characterize the waste gas, a literature review to obtain preliminary elimination capacities and removal efficiencies, modeling, and finally bench-scale and/or pilot testing on the actual waste stream. During preliminary analysis, it is important to determine the major and minor contaminants, concentrations, flow, loading rates, temperature, pressure, and humidity. The average, minimum, and maximum values should be determined over an extended period, especially for variable loading (e.g. batch processes). Modeling is extremely useful because it allows manipulation of these variables without the often time-consuming and expensive modifications in laboratory or pilot-scale processes. 
4.1.3 Model Description and Application. The dynamic model used in this study has been incorporated into a user-friendly software: Biofilter ${ }^{\mathrm{TM}}$ (Crittenden et al., 2002). Hautakangas et al. (1999) and Li et al. (2002) provide a detailed description of the physical and chemical processes and the corresponding equations and assumptions used in this model. Several different mathematical biofilm and biofilter models have been developed in recent years as described by Devinney et al. (1999, pp113-139) and Li (2002, pp. 36-37), but the major differences between these models and Biofilter ${ }^{\mathrm{TM}}$ are:

1. Biofilter ${ }^{\mathrm{TM}}$ accounts for the growth and decay of active biomass as a function of the axial biofilter bed position (z), biofilm depth on the packing material, and time instead of assuming a constant biomass concentration through the depth of the biofilter or only a surface reaction on the packing material;

2. Biofilter ${ }^{\mathrm{TM}}$ is specifically designed for the control of odorous sulfur compounds instead of VOCs (although it is may be applied to and is easily adapted to VOCs).

While biofiltration is a cost-effective method to eliminate odorous reduced sulfur emissions from a WWTP, current biofilter design and operation methods could be improved with tools such as Biofilter $^{\text {TM }}$. This could lead to a more effective design, improved efficiency and reliability, and reduced capital and operational costs. WWTP personnel and consultants can use this valuable tool for the design and performance optimization of biofilters.

\subsection{METHODOLOGY}

The objective of this study was to use Biofilter ${ }^{\mathrm{TM}}$ as a tool for the design and optimization of a proposed lava rock biofilter intended to treat odorous air containing $\mathrm{H}_{2} \mathrm{~S}$. This 
was the basis for a preliminary design study for an existing WWTP experiencing an odor control problem.

In this study, Biofilter ${ }^{\mathrm{TM}}$ is used to evaluate the following design and operation parameters and the effect they have on biofilter performance and design sizing:

1) influent feed concentration,

2) temperature,

3) media size,

4) residence time (air flow and bed volume), and

5) dynamic response to changes in influent concentration.

4.2.1 Biofilter Microbiology, Packing Material, and Bed Depth. The biofilter packing material acts as the support for the microorganisms that oxidize the odorous compounds. Treating $\mathrm{H}_{2} \mathrm{~S}$ and other reduced sulfur compounds by biofiltration can be accomplished by passing odorous air through a biofilter containing a media with a high surface area to volume ratio that will provide sufficient area for extensive biofilm growth. Irrigation of the packing material with wastewater may be required if the feed air is too dry or the media lacks biological nutrients. Several organisms have been cited in the treatment of reduced sulfur compounds using biofiltration, including members of the genus Acidithiobacillus.

Acidithiobacillus sp. are obligate chemoautotrophic bacteria that obtain carbon for cell synthesis from the fixation of atmospheric carbon dioxide and may obtain energy from the oxidation of reduced sulfur compounds. Acidithiobacillus sp. are also acidophiles that exhibit optimum growth under acidic conditions. Martin et al. (2002) identify Acidithiobacillus ferrooxidans as the predominant species responsible for $\mathrm{H}_{2} \mathrm{~S}$ removal in a pilot-scale and full- 
scale lava rock biofilters operated at a rinse water $\mathrm{pH}$ of approximately 2. A. ferrooxidans may oxidize $\mathrm{H}_{2} \mathrm{~S}$ directly or it may oxidize $\mathrm{Fe}^{+2}$ to $\mathrm{Fe}^{+3}$ which, in turn, may react with the $\mathrm{H}_{2} \mathrm{~S}$ ( $\mathrm{Li}$, 2002, pp. 214-230).

Many biofilters use an organic packing material (e.g., compost, peat, wood chips, bark, soil, and hog fuel) as the support for biological growth. Although they do not require nutrient addition and can achieve high VOC removals and even $99.5 \%$ to $99.9 \% \mathrm{H}_{2} \mathrm{~S}$ removal (Yang and Allen, 1994 and Wani et al., 1998), biofilters containing organic packing material tend to dry out and clog. Therefore, biofilters containing organic packing material often require a larger blower (to overcome the high pressure drop) and frequent, labor-intensive replacement of packing material. Organic material is also susceptible to degradation under acidic conditions.

Lava rock, however, is durable at low $\mathrm{pH}$ and the porous structure allows retention of nutrient-laden rinse water and provides a large surface area for biofilm growth. It has been used successfully as a packing material in many biofilters used for odor control achieving $\mathrm{H}_{2} \mathrm{~S}$ removal efficiencies above 98\% (Chitwood et al., 1999; Morton and Caballero, 1996; and Martin et al., 2002). The original red lava rock installed in the full-scale biofilter at Cedar Rapids (Iowa) Water Pollution Control Facilities (WPCF) in August 1998 continues to achieve high $\mathrm{H}_{2} \mathrm{~S}$ removal (Martin et al. 2002). Chitwood and Devinney (2001) reported 7\% settling in a pilotscale "acid-gas biofilter" (average $\mathrm{pH}$ approximately 4) containing black lava rock; while the black lava rock showed significant loss in studies at low $\mathrm{pH}$, red lava rock was resistant to dissolution in sulfuric acid even at $\mathrm{pH} 1$. Morton and Caballero (1996) used plastic packing material in a pilot-scale biofilter used for $\mathrm{H}_{2} \mathrm{~S}$ removal but the $\mathrm{H}_{2} \mathrm{~S}$ removal was lower than for porous rock. 
In addition to choosing the proper packing material, it is important to choose a proper packing material depth (bed depth). The bed depth (along with the area perpendicular to flow) will determine the bed volume and, thus, the residence time. Without sufficient residence time, there will be incomplete $\mathrm{H}_{2} \mathrm{~S}$ removal. Model simulations showed that for a constant bed volume (and residence time), $\mathrm{H}_{2} \mathrm{~S}$ removal was independent of bed area (perpendicular to flow) and bed depth (data not shown). However, functional considerations are important in selecting the bed depth. The biofilter bed depth should be sufficient to provide adequate gas flow and rinse water distribution throughout the depth of the bed. But, it should not be so deep that there is too much weight on the lava rock support and that changing the packing material becomes difficult. Common biofilter packing depths range from 3 to $5 \mathrm{ft}$ (Devinny et al., 1999; Morton and Caballero, 1996; and Torres et al., 1997). Cedar Rapids WPCF has successfully removed $\mathrm{H}_{2} \mathrm{~S}$ using a red lava rock bed depth of $6 \mathrm{ft}$. (Martin et al., 2002). A bed depth of 6 feet was chosen in this study to save space by providing a larger bed volume per unit area; thus, a 6-foot bed depth was used for all model simulations.

4.2.2 Design Criteria. The preliminary design was for a proposed biofiltration facility to treat odors from a metering structure and an inverted siphon experiencing odor problems. The average wastewater flow to the metering structure and inverted siphon was $3.9 \mathrm{~m}^{3} / \mathrm{sec}(90$ MGD). The biofilter would receive an odorous air-flow of $283 \mathrm{~m}^{3} / \mathrm{min}\left(10,000 \mathrm{ft}^{3} / \mathrm{min}\right)$ with potential future expansion to a maximum total flow of up to $566 \mathrm{~m}^{3} / \mathrm{min}\left(20,000 \mathrm{ft}^{3} / \mathrm{min}\right)$. Analysis indicated an average inlet $\mathrm{H}_{2} \mathrm{~S}$ concentration of $4 \mathrm{ppm}_{\mathrm{v}}$ and a maximum $\mathrm{H}_{2} \mathrm{~S}$ concentration of $20 \mathrm{ppm}_{\mathrm{v}}$; however, the analysis was only carried out for a short period on two separate days, so significantly higher concentrations are anticipated. Based on the influent air temperature, the average biofilter temperature was estimated to be $17^{\circ} \mathrm{C}\left(63^{\circ} \mathrm{F}\right)$, while the 
minimum winter temperature was estimated to be $15^{\circ} \mathrm{C}\left(59^{\circ} \mathrm{F}\right)$. Space constraints limited the maximum biofilter area to $370 \mathrm{~m}^{2}\left(4,000 \mathrm{ft}^{2}\right)$. The design criteria are summarized in Table 4.1. Based on these design requirements, the model simulations were run for the following range of conditions:

1) feed $\mathrm{H}_{2} \mathrm{~S}$ concentration: $20 \mathrm{ppm}_{\mathrm{v}}$ (average) - $80 \mathrm{ppm}_{\mathrm{v}}$ (maximum),

2) air flow: $283 \mathrm{~m}^{3} / \mathrm{min}$ (average) $-566 \mathrm{~m}^{3} / \mathrm{min}$ (maximum), and

3) biofilter temperature: $17^{\circ} \mathrm{C}$ (average) $-15^{\circ} \mathrm{C}$ (minimum).

\section{Table 4.1: Summary of Biofilter Design Criteria.}

\begin{tabular}{|r|c|c|c|}
\hline Criterion & Minimum & Average & Maximum \\
\hline Inlet $\mathbf{H}_{2}$ S Concentration (ppmv) & & 20 & 80 \\
\hline Feed Air Flow ( $\left.\mathbf{m}^{\mathbf{3}} / \mathbf{m i n}\right)$ & & 283 & 566 \\
\hline Biofilter Temperature $\left.\mathbf{(}^{\mathbf{0}} \mathbf{C}\right)$ & 15 & 17 & \\
\hline Available Area for Biofilter $\left(\mathbf{m}^{\mathbf{3}}\right)$ & & & 370 \\
\hline
\end{tabular}

4.2.3 Model Simulations. In this study, Biofilter ${ }^{\mathrm{TM}}$ was run using the calibration/validation values obtained from full-scale and pilot-scale data at the Cedar Rapids WPCF. For detailed information on the model parameter input values used in this study, see Appendix A. The input values are listed in Table A.5 of Appendix A. Although these values were obtained over a wide range of dynamic operating conditions, calibration/validation values determined from the Cedar Rapids WPCF may vary from those in another similar biofilter due to differences such as the feed flow and concentration and biofilter temperature and microbiology.

The biofilter design in this chapter was for feed concentrations of $10 \mathrm{ppm}_{\mathrm{v}}$ to $80 \mathrm{ppm}_{\mathrm{v}}$ compared to approximately $20 \mathrm{ppm}_{\mathrm{v}}$ to $300 \mathrm{ppm}_{\mathrm{v}}$ for Cedar Rapids WPCF. Therefore, the 
model-generated plots in this study should only be used as a preliminary design tool. Devinny et al. (1999, p. 144) emphasize that while models can be useful in designing and sizing biofilters, the potentially large uncertainty in model parameters require bench-scale and/or pilot testing on the actual waste stream. Appendix B discusses the uncertainty in the model simulated effluent $\mathrm{H}_{2} \mathrm{~S}$ concentration due to the uncertainty in the flow and temperature for the Cedar Rapids WPCF calibration and validation.

In this design study, Biofilter ${ }^{\mathrm{TM}}$ was used to generate $\mathrm{H}_{2} \mathrm{~S}$ effluent concentrations for various bed characteristics and operating conditions. The model simulations were for a biofilter run time of 365 days from start-up, which was necessary to achieve a steady-state outlet $\mathrm{H}_{2} \mathrm{~S}$ concentration. Constant biofilter conditions were maintained during each individual model simulation, except for the simulations in response to a dynamic influent concentration. It must be emphasized that actual full-scale biofilter operations will typically not be at constant loading and will not attain steady-state.

It must also be emphasized that this preliminary design was performed assuming that the only odor-causing compound was $\mathrm{H}_{2} \mathrm{~S}$, even though other odorous compounds may be present. Although Biofilter ${ }^{\mathrm{TM}}$ was only used for $\mathrm{H}_{2} \mathrm{~S}$ removal in this study, it has also been calibrated for the removal of methyl mercaptan and can be used for other reduced sulfur compounds and VOCs (Li et al., 2003). Additionally, lava rock biofilters have been shown to remove other reduced sulfur compounds, ammonia, and VOCs. For example, Cedar Rapids WPCF achieved 98\% removal of $3.13 \mathrm{ppm}_{\mathrm{v}}$ methyl mercaptan, $98 \%$ removal of $0.12 \mathrm{ppm}_{\mathrm{v}}$ dimethyl disulfide, $58 \%$ removal of $1.25 \mathrm{ppm}_{\mathrm{v}}$ carbonyl sulfide, and 38\% removal of $0.63 \mathrm{ppm}_{\mathrm{v}}$ dimethyl sulfide (Martin et al., 2002). The Neenah-Menasha (Wisconsin) WWTP reported $40 \%$ to $80 \%$ VOC removal and approximately $60 \%$ to $100 \%$ ammonia removal in a lava rock biofilter (Vic, 2001). The 
final biofilter design should account for any other odor-causing compounds as well as any potential increased loading due to any anticipated new $\mathrm{H}_{2} \mathrm{~S}$ sources.

\subsection{RESULTS AND DISCUSSION}

Several biofilter performance simulation curves are presented in the following discussion. First, the biofilter performance is characterized according to methods described in current literature. However, additional simulation curves are presented in this discussion as an alternative to the methods cited in the current literature. Finally, sizing design simulation curves using the actual design criteria specified in Table 4.1 are presented.

Biofilter ${ }^{\mathrm{TM}}$ was used as a tool in the preliminary design of a lava rock biofilter to remove $\mathrm{H}_{2} \mathrm{~S}$ from odorous air. Model simulations were run using the input parameters determined in Appendix A to generate model simulated effluent $\mathrm{H}_{2} \mathrm{~S}$ concentrations as a function of time. Steady state effluent $\mathrm{H}_{2} \mathrm{~S}$ concentrations were generated using 365 days of constant biofilter input conditions; additional simulations were run for dynamic conditions. The model simulated steady state effluent $\mathrm{H}_{2} \mathrm{~S}$ concentrations were used to generate performance and design plots, each individual point generated from a single model simulation. Because these plots were derived from model simulations instead of actual data from existing biofilters, it is important to supplement them with lab and/or pilot scale studies.

4.3.1 Removal Capacity as a Function of Loading. One of the most common methods of characterizing biofilter performance is plotting elimination capacity as a function of pollutant loading. Loading can be based on either bed volume or bed surface area, but volumetric loading is more common. Volumetric loading (L) and elimination capacity (EC) are defined as follows:

$$
\mathrm{L}=\left[\mathrm{H}_{2} \mathrm{~S}\right]_{\text {in }}(\mathrm{Q} / \mathrm{V})
$$




$$
\mathrm{EC}=\left(\left[\mathrm{H}_{2} \mathrm{~S}\right]_{\text {in }}-\left[\mathrm{H}_{2} \mathrm{~S}\right]_{\text {out }}\right)(\mathrm{Q} / \mathrm{V})
$$

Where

$$
\begin{aligned}
& {\left[\mathrm{H}_{2} \mathrm{~S}\right]_{\text {in }}=\text { influent } \mathrm{H}_{2} \mathrm{~S} \text { concentration, }} \\
& {\left[\mathrm{H}_{2} \mathrm{~S}\right]_{\text {out }}=\text { effluent } \mathrm{H}_{2} \mathrm{~S} \text { concentration, }} \\
& \mathrm{Q}=\text { gas volumetric flow rate, and } \\
& V=\text { bed volume (empty bed). }
\end{aligned}
$$

Devinny et al. (1999 p. 20) illustrate how to determine the critical elimination capacity (also called the critical load) and the maximum elimination capacity. The elimination capacity cannot exceed volumetric loading; it can only be equal to or less than volumetric loading. In a plot of elimination capacity as a function of volumetric loading, a straight line through the origin with a slope of one represents $100 \%$ elimination (see Figure 4.1). Actual elimination may approach $100 \%$ at low loading, but above the critical elimination capacity (or critical load) less than $100 \%$ elimination occurs. At very high loading, the elimination capacity approaches a maximum: the maximum elimination capacity $\left(\mathrm{EC}_{\max }\right)$.

The maximum elimination capacity is typically $10 \mathrm{~g} / \mathrm{m}^{3}-\mathrm{hr}$ to $300 \mathrm{~g} / \mathrm{m}^{3}-\mathrm{hr}$ for biofilters treating common pollutants and the "maximum overall elimination capacity is independent of contaminant concentration and residence time within a reasonable range of operating conditions" (Devinny et al., 1999, p. 20). Devinny et al. (1999, p. 145) explain that at extreme loading rates, elimination capacities differ due to the different driving forces of removal. Yang and Allen (1994) reported that $\mathrm{EC}_{\max }$ is a function of packing material properties and operating conditions. 


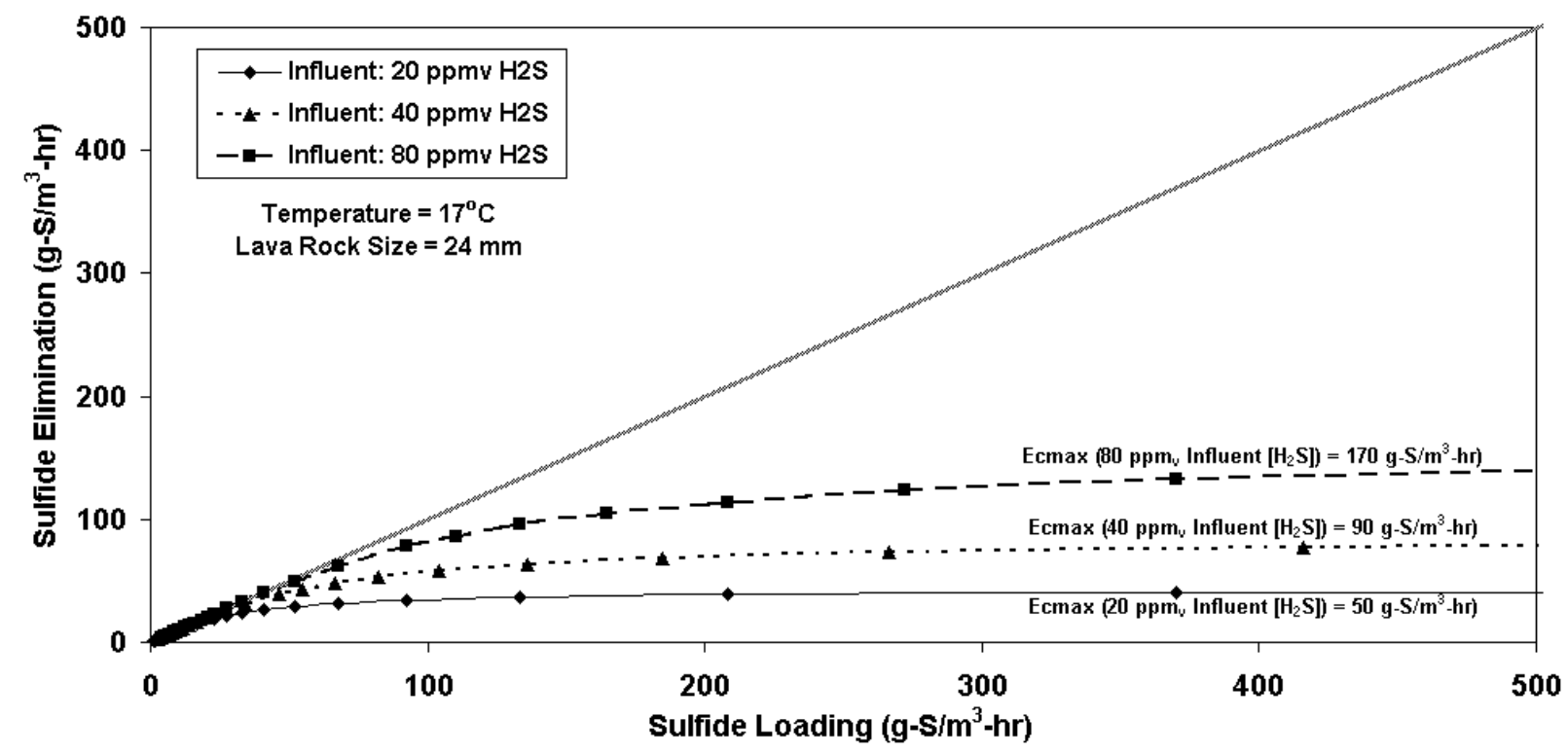

Figure 4.1: Model Simulated Sulfide Elimination as a Function of Sulfide Loading for Various Influent Hydrogen Sulfide Concentrations.

Model simulations in this study show that $\mathrm{EC}_{\max }$ does depend on influent $\mathrm{H}_{2} \mathrm{~S}$ concentration and packing material diameter. Figure 4.1 shows the elimination capacity as a function of loading for three different influent $\mathrm{H}_{2} \mathrm{~S}$ concentrations $\left(20 \mathrm{ppm}_{\mathrm{v}}, 40 \mathrm{ppm}_{\mathrm{v}}\right.$, and 80 $\left.\mathrm{ppm}_{\mathrm{v}}\right)$. The model simulations were run at constant values of temperature $\left(17^{\circ} \mathrm{C}\right)$, lava rock size (24 mm), flow $\left(283 \mathrm{~m}^{3} / \mathrm{sec}\right)$, and bed depth $(1.83 \mathrm{~m})$. For a constant residence time, the model simulated effluent $\mathrm{H}_{2} \mathrm{~S}$ concentration was independent of flow and bed depth, so the plots in Figure 4.1 are not limited to the specified flow and depth (data not shown). Each point on the plot represents the effluent $\mathrm{H}_{2} \mathrm{~S}$ concentration obtained from a single model simulation run for 365 days. Loading was increased by decreasing the packing material area (perpendicular to flow); because the depth is constant, this is equivalent to decreasing the packing material volume (and decreasing residence time since flow is constant). The $\mathrm{EC}_{\max }$ is approximately $170 \mathrm{~g}-\mathrm{S} / \mathrm{m}^{3}$ $\mathrm{hr}$ at $80 \mathrm{ppm}_{\mathrm{v}} \mathrm{H}_{2} \mathrm{~S}$ feed, compared to approximately $90 \mathrm{~g}-\mathrm{S} / \mathrm{m}^{3}-\mathrm{hr}$ and $50 \mathrm{~g}-\mathrm{S} / \mathrm{m}^{3}-\mathrm{hr}$ at $40 \mathrm{ppm}_{\mathrm{v}}$ 
and $20 \mathrm{ppm}_{\mathrm{v}} \mathrm{H}_{2} \mathrm{~S}$ feed, respectively. When the packing material size was increased to $48 \mathrm{~mm}$, $\mathrm{EC}_{\max }$ decreased to approximately $22 \mathrm{~g}-\mathrm{S} / \mathrm{m}^{3}-\mathrm{hr}$ and when it was decreased to $12 \mathrm{~mm}, \mathrm{EC}_{\max }$ increased to approximately $85 \mathrm{~g}-\mathrm{S} / \mathrm{m}^{3}-\mathrm{hr}$ at $20 \mathrm{ppm}_{\mathrm{v}} \mathrm{H}_{2} \mathrm{~S}$ feed (data not shown). Yang and Allen (1994) also reported a comparable $\mathrm{EC}_{\max }$ of $130 \mathrm{~g}-\mathrm{S} / \mathrm{m}^{3}-\mathrm{hr}$ for influent $\mathrm{H}_{2} \mathrm{~S}$ concentrations of 120 $\mathrm{ppm}_{\mathrm{v}}$ to $2,000 \mathrm{ppm}_{\mathrm{v}}$ for compost packing (with a particle size from less than $1 \mathrm{~mm}$ up to $12 \mathrm{~mm}$ ).

The limit in elimination, $\mathrm{EC}_{\max }$, at the high loading shown in Figure 4.1 may be due to the low residence time at the high loading rate. At $170 \mathrm{~g}-\mathrm{S} / \mathrm{m}^{3}-\mathrm{hr}$ for $80 \mathrm{ppm}_{\mathrm{v}} \mathrm{H}_{2} \mathrm{~S}$ feed, the residence time is only 0.41 seconds. Residence time is discussed further in Section 4.3.3. The higher elimination at the higher loading may also be due to a higher concentration of active biomass in the biofilm at the higher loading. Because the concentration of biomass that can form within the biofilm is limited by space constraints, the increase in elimination capacity may be limited to the maximum value, $\mathrm{EC}_{\max }$. Devinney et al. (1999, pp. 68-71) point out that actual loading limits in biofilters may also be due to an oxygen limitation.

Figure 4.2 shows the model simulated average active biomass concentration in the biofilm on the lava rock within the biofilter bed (expressed as grams active biomass per liter biofilm) as a function of the sulfide loading for various influent hydrogen sulfide concentrations (20 $\mathrm{ppm}_{\mathrm{v}}$ and $80 \mathrm{ppm}_{\mathrm{v}}$ ) at the effluent and at $46 \mathrm{~cm}$ from the influent. The constant temperature $\left(17^{\circ} \mathrm{C}\right)$, lava rock size $(24 \mathrm{~mm})$, air flow $(283 \mathrm{~m} 3 / \mathrm{sec})$, and bed depth $(1.83 \mathrm{~m})$ are identical to those in Figure 4.1. The simulation curves in Figure 4.2 show that the active biomass concentration approaches a limit at high sulfide loading rates and this limiting biomass concentration increases with increasing influent hydrogen sulfide concentration. The maximum biomass concentration approaches $12 \mathrm{~g} / \mathrm{L}$ at $80 \mathrm{ppm}_{\mathrm{v}} \mathrm{H}_{2} \mathrm{~S}$ feed, compared to approximately 8.0 $\mathrm{g} / \mathrm{L}$ at $20 \mathrm{ppm}_{\mathrm{v}} \mathrm{H}_{2} \mathrm{~S}$ feed, respectively. 


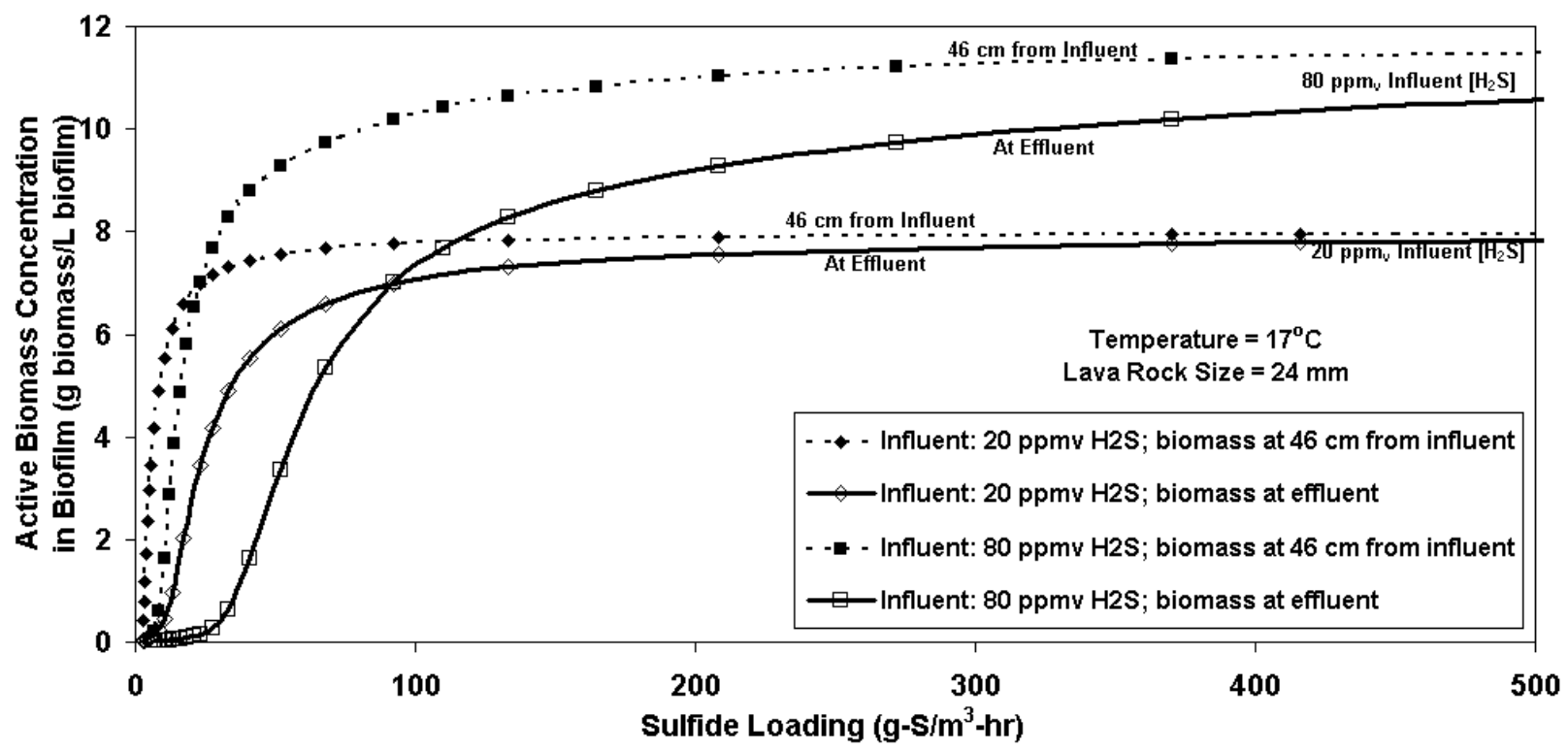

Figure 4.2: Model Simulated Average Active Biomass Concentration in the Biofilm as a Function of Sulfide Loading for Various Influent Hydrogen Sulfide Concentrations and Bed Locations.

The biomass concentrations shown in Figure 4.2 are the depth-average concentrations; biomass concentration on the packing material is greatest at the surface of the biofilm (at the biofilm-air interface) and decreases deeper into the biofilm. The surface biomass concentration is $98.3 \mathrm{~g} / \mathrm{L}$ for $80 \mathrm{ppm}_{\mathrm{v}} \mathrm{H}_{2} \mathrm{~S}$ feed and $370 \mathrm{~g}-\mathrm{S} / \mathrm{m}^{3}-\mathrm{hr}$ loading at $46 \mathrm{~cm}$ from the influent (data not shown). This surface biomass concentration is close to the user input value of the maximum biomass concentration of $100 \mathrm{~g} / \mathrm{L}$ and it approaches this maximum value at the influent. Also, increasing the model input value of the maximum biomass concentration results in an increase in the biomass concentration within the biofilter and an increase in $\mathrm{EC}_{\max }$. When the model input value of the maximum biomass concentration is increased from $100 \mathrm{~g} / \mathrm{L}$ to $1,000 \mathrm{~g} / \mathrm{L}$ for an influent of $20 \mathrm{ppm}_{\mathrm{v}} \mathrm{H}_{2} \mathrm{~S}, \mathrm{EC}_{\max }$ increases from $50 \mathrm{~g}-\mathrm{S} / \mathrm{m}^{3}-\mathrm{hr}$ to $200 \mathrm{~g}-\mathrm{S} / \mathrm{m}^{3}-\mathrm{hr}$.

Figure 4.2 also illustrates that the biomass concentration is higher closer to the influent than at the effluent of the biofilter, especially at lower loading rates. For $20 \mathrm{ppm}_{\mathrm{v}} \mathrm{H}_{2} \mathrm{~S}$ feed at a 
loading of $17.0 \mathrm{~g}-\mathrm{S} / \mathrm{m}^{3}-\mathrm{hr}$, the average biomass concentration is $6.6 \mathrm{~g} / \mathrm{L}$ at $46 \mathrm{~cm}$ from the influent, compared to $2.0 \mathrm{~g} / \mathrm{L}$ at the effluent. At a similar loading, the difference in biomass concentration through the column is greater for a higher influent hydrogen sulfide concentration. At a loading of $18.3 \mathrm{~g}-\mathrm{S} / \mathrm{m}^{3}-\mathrm{hr}$, the average biomass concentration is $5.8 \mathrm{~g} / \mathrm{L}$ at $46 \mathrm{~cm}$ from the influent, compared to $0.08 \mathrm{~g} / \mathrm{L}$ at the effluent for $80 \mathrm{ppm}_{\mathrm{v}} \mathrm{H}_{2} \mathrm{~S}$ feed.

4.3.2 Removal Efficiency as a Function of Loading. For a biofilter operating at a high elimination capacity (approaching $\mathrm{EC}_{\max }$ ), the pollutant removal efficiency will be low while biofilters operating at or below the critical elimination capacity will have a pollutant removal efficiency approaching $100 \%$. However, it is often difficult to accurately determine the removal efficiency from a plot of elimination capacity as a function of loading. Also, regulatory permits for VOCs typically specify a percent removal of the pollutant instead of an elimination rate (Devinny et al. 1999, p.144). Hence, it is often more convenient to express biofilter performance in terms of percent removal of the pollutant. The removal efficiency (RE) is defined as follows:

$$
\operatorname{RE}(\%)=\left(\left[\mathrm{H}_{2} \mathrm{~S}\right]_{\text {in }}-\left[\mathrm{H}_{2} \mathrm{~S}\right]_{\text {out }}\right) /\left[\mathrm{H}_{2} \mathrm{~S}\right]_{\text {in }} \times 100 \%
$$

Morton and Caballero (1996) collected data from a pilot-scale biofilter containing porous rock packing material for feed concentrations of $10 \mathrm{ppm}_{\mathrm{v}}$ to $300 \mathrm{ppmv}_{2} \mathrm{~S}$. A plot of $\mathrm{H}_{2} \mathrm{~S}$ removal efficiency as a function of loading rate shows greater than $98 \% \mathrm{H}_{2} \mathrm{~S}$ removal at loading rates below $17 \mathrm{~g}-\mathrm{S} / \mathrm{m}^{3}-\mathrm{hr}$, but removal efficiency decreases as loading increases. At loadings between $40 \mathrm{~g}-\mathrm{S} / \mathrm{m}^{3}-\mathrm{hr}$ and $80 \mathrm{~g}-\mathrm{S} / \mathrm{m}^{3}-\mathrm{hr}, \mathrm{H}_{2} \mathrm{~S}$ removal varies from approximately $80 \%$ to $100 \%$. At loadings above $85 \mathrm{~g}-\mathrm{S} / \mathrm{m}^{3}-\mathrm{hr}, \mathrm{H}_{2} \mathrm{~S}$ removal varies from approximately $68 \%$ to $80 \%$. However, the data is scattered, probably because variations in influent $\mathrm{H}_{2} \mathrm{~S}$ concentration are not accounted for. 
Figure 4.3, showing model simulated plots of removal efficiency as a function of loading for various influent $\mathrm{H}_{2} \mathrm{~S}$ concentrations $\left(20 \mathrm{ppm}_{\mathrm{v}}, 40 \mathrm{ppm}_{\mathrm{v}}\right.$, and $80 \mathrm{ppm}_{\mathrm{v}}$ ), shows a similar trend in removal efficiency decrease with increased loading. It also highlights the fact that influent $\mathrm{H}_{2} \mathrm{~S}$ concentration determines the shape of the curve. At lower influent $\mathrm{H}_{2} \mathrm{~S}$ concentrations, the $\mathrm{H}_{2} \mathrm{~S}$ removal efficiency drops much more rapidly with increased loading. At an influent $\mathrm{H}_{2} \mathrm{~S}$ concentration of $20 \mathrm{ppm}_{\mathrm{v}}, \mathrm{H}_{2} \mathrm{~S}$ removal efficiency is only $83 \%$ at $25 \mathrm{~g}-\mathrm{S} / \mathrm{m}^{3}-\mathrm{hr}$ loading, compared to $99 \%$ removal efficiency for the same loading but at an influent concentration of 80 $\mathrm{ppm}_{\mathrm{v}}$. The removal efficiency is higher at the higher influent concentration because the residence time is lower. Residence time $(\tau)$ is defined as follows:

$$
\tau=\varepsilon \mathrm{V} / \mathrm{Q}
$$

Where

$\varepsilon=$ bed porosity (unitless).

Since the bed porosity is not easily measured and may change with time, empty bed residence time (EBRT) is often used:

$$
\mathrm{EBRT}=\mathrm{V} / \mathrm{Q}
$$

Sometimes, $\tau$ is referred to as the true residence time or the packed bed residence time since EBRT assumes no packing material is present; and thus $\tau$ will be less than EBRT. Comparing Equation 4.4 and Equation 4.5:

$$
\tau=\varepsilon(\mathrm{EBRT})
$$

In this study, $\varepsilon$ was experimentally determined to be 0.40 .

Loading is based on the mass of influent $\mathrm{H}_{2} \mathrm{~S}$ per volume of bed (see equation 4.2); to achieve equal loading at a lower influent $\mathrm{H}_{2} \mathrm{~S}$ concentration, the flow must be increased (residence time decreased) when the same bed volume is used. As residence time decreases, 
removal efficiency also decreases. At $33 \mathrm{~g}-\mathrm{S} / \mathrm{m}^{3}-\mathrm{hr}$ loading and an influent $\mathrm{H}_{2} \mathrm{~S}$ concentration of $20 \mathrm{ppm}_{\mathrm{v}}$, the removal efficiency is $72 \%$ and the residence time is 1.1 seconds; at the same loading, and an influent $\mathrm{H}_{2} \mathrm{~S}$ concentration of $80 \mathrm{ppm}_{\mathrm{v}}$ the removal efficiency is $99 \%$ and the residence time is 4.5 seconds. This illustrates why biofilter design and performance is frequently expressed in terms of residence time.

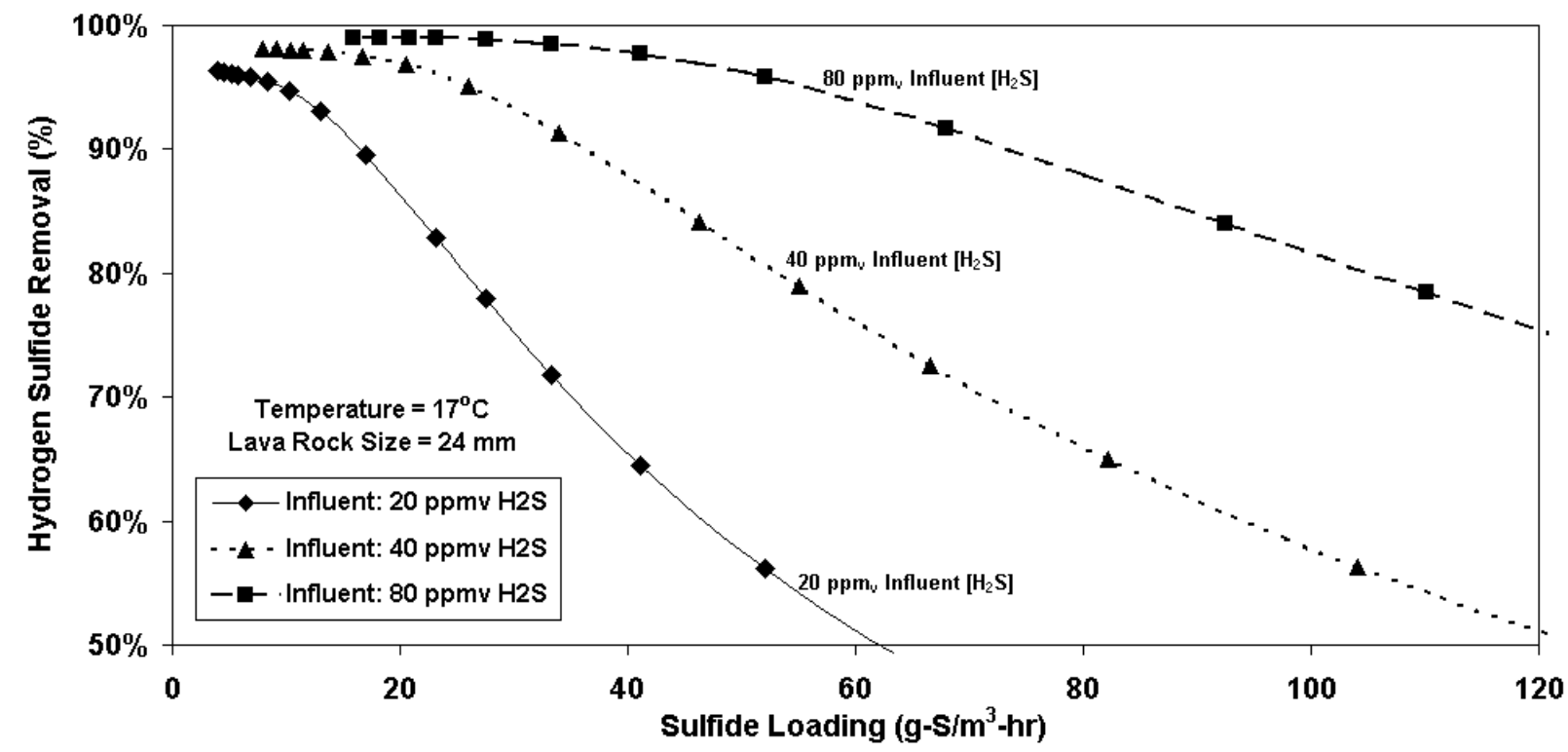

Figure 4.3: Model Simulated Hydrogen Sulfide Removal as a Function of Sulfide Loading for Various Influent Hydrogen Sulfide Concentrations.

4.3.3 Removal Efficiency as a Function of Residence Time. Figure 4.4 shows model simulated plots of removal efficiency as a function of residence time for various influent $\mathrm{H}_{2} \mathrm{~S}$ concentrations $\left(20 \mathrm{ppm}_{\mathrm{v}}, 40 \mathrm{ppm}_{\mathrm{v}}\right.$, and $\left.80 \mathrm{ppm}_{\mathrm{v}}\right)$. At residence times below 2 seconds, there is a very sharp increase in removal efficiency with increasing residence time for all feed concentrations. Yang and Allen (1994) show a similar plot of $\mathrm{H}_{2} \mathrm{~S}$ removal efficiency as a function of residence time for a compost biofilter at $15 \mathrm{~g}-\mathrm{S} / \mathrm{m}^{3}-\mathrm{hr}$ to $55 \mathrm{~g}-\mathrm{S} / \mathrm{m}^{3}-\mathrm{hr}$ loading. 
Initially, there is a rapid increase in removal efficiency, approaching a maximum of nearly $100 \%$ removal efficiency. Although this maximum removal efficiency is higher than that shown in Figure 4.4, the removal efficiency is less than $94 \%$ at 7 seconds residence time compared to more than $99 \%$ removal efficiency for the $80 \mathrm{ppm}_{\mathrm{v}}$ feed in Figure 4.4 (an equivalent loading range) at the same 7-second residence time. The Cedar Rapids WPCF full-scale biofilter, operating at a residence time of 8.4 seconds and $25^{\circ} \mathrm{C}$ achieves removal efficiencies of greater than $96 \%$; the pilot-scale biofilter, operating at a residence time of 7.5 seconds and $20^{\circ} \mathrm{C}$, achieves removal efficiencies of greater than 99\% (Martin et al., 2002).

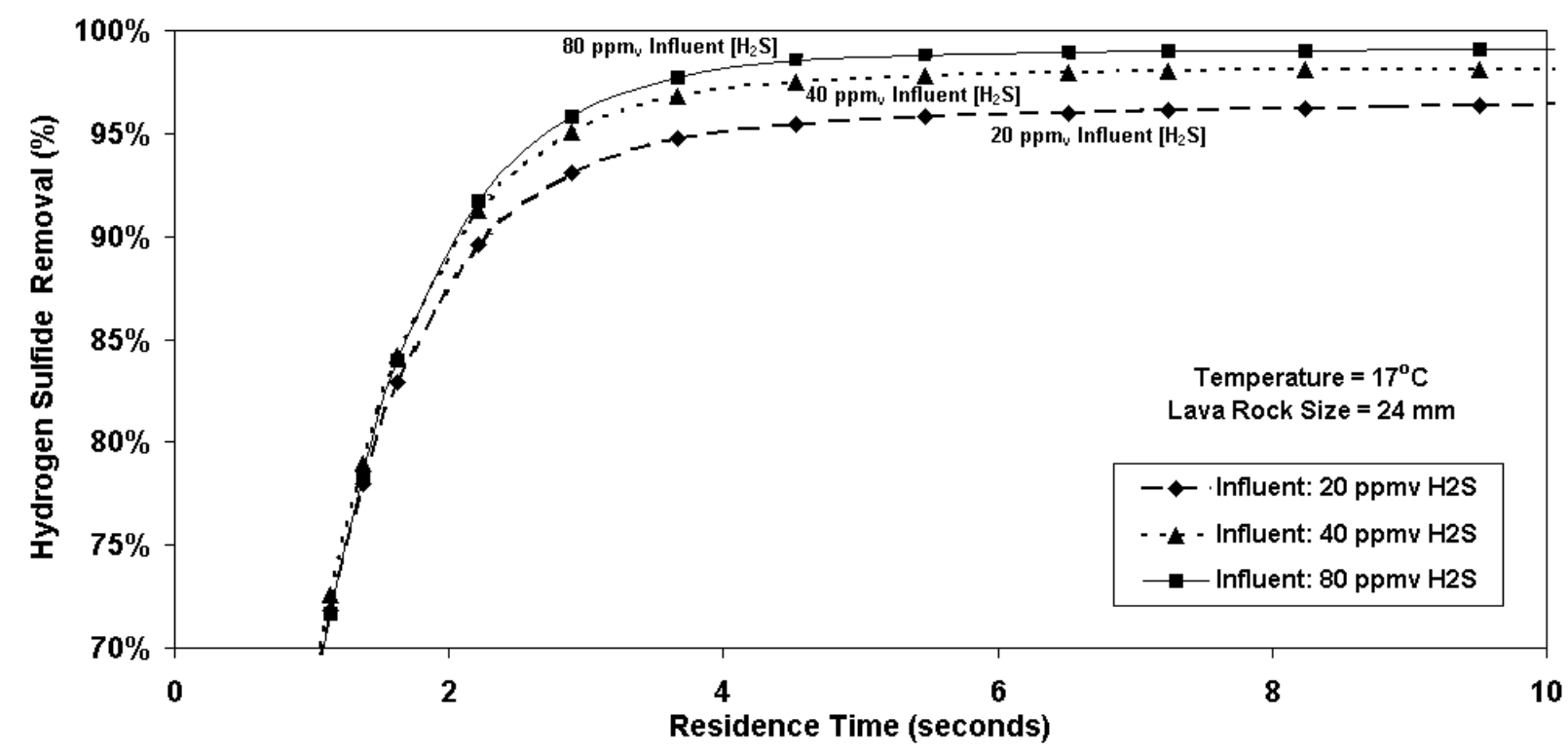

Figure 4.4: Model Simulated Hydrogen Sulfide Removal as a Function of Residence Time for Various Influent Hydrogen Sulfide Concentrations.

Figure 4.4 shows that above 5 seconds residence time, removal efficiency approaches a maximum of approximately $95 \%$ for a $20 \mathrm{ppm}_{\mathrm{v}}$ influent $\mathrm{H}_{2} \mathrm{~S}$ concentration and approximately $99 \%$ for an $80 \mathrm{ppm}_{\mathrm{v}}$ influent $\mathrm{H}_{2} \mathrm{~S}$ concentration. Figure 4.4 also highlights the significant effect 
influent $\mathrm{H}_{2} \mathrm{~S}$ concentration has on $\mathrm{H}_{2} \mathrm{~S}$ removal efficiency at residence times above 2 seconds. As the influent $\mathrm{H}_{2} \mathrm{~S}$ concentration increases, removal efficiency increases because the final effluent $\mathrm{H}_{2} \mathrm{~S}$ concentration approaches a limiting minimum effluent concentration as shown in Figure 4.5 (discussed below). While all three effluent $\mathrm{H}_{2} \mathrm{~S}$ concentrations approach the same minimum effluent $\mathrm{H}_{2} \mathrm{~S}$ concentration, the total removal is greatest for the highest influent $\mathrm{H}_{2} \mathrm{~S}$ concentration. Figure 4.4 shows the removal efficiency at a 2.2 -second residence time for 40 $\operatorname{ppm}_{v} \mathrm{H}_{2} \mathrm{~S}$ feed is $91 \%$, which is slightly lower than the $92 \%$ removal efficiency for $80 \mathrm{ppm}_{\mathrm{v}} \mathrm{H}_{2} \mathrm{~S}$ feed. However, Figure 4.5 shows that the effluent $\mathrm{H}_{2} \mathrm{~S}$ concentration for the same 2.2-second residence time and $80 \mathrm{ppm}_{\mathrm{v}} \mathrm{H}_{2} \mathrm{~S}$ feed is $6,600 \mathrm{ppb}_{\mathrm{v}}$, almost twice as high as the 3,500 ppb effluent $\mathrm{H}_{2} \mathrm{~S}$ concentration for the $40 \mathrm{ppm}_{\mathrm{v}} \mathrm{H}_{2} \mathrm{~S}$ feed. Hence, a plot showing removal efficiency as the performance characteristic may be deceptive. Therefore, a plot showing the effluent concentration may be more useful than a plot showing removal efficiency if a biofilter is designed to reach a target effluent concentration for an odorous compound.

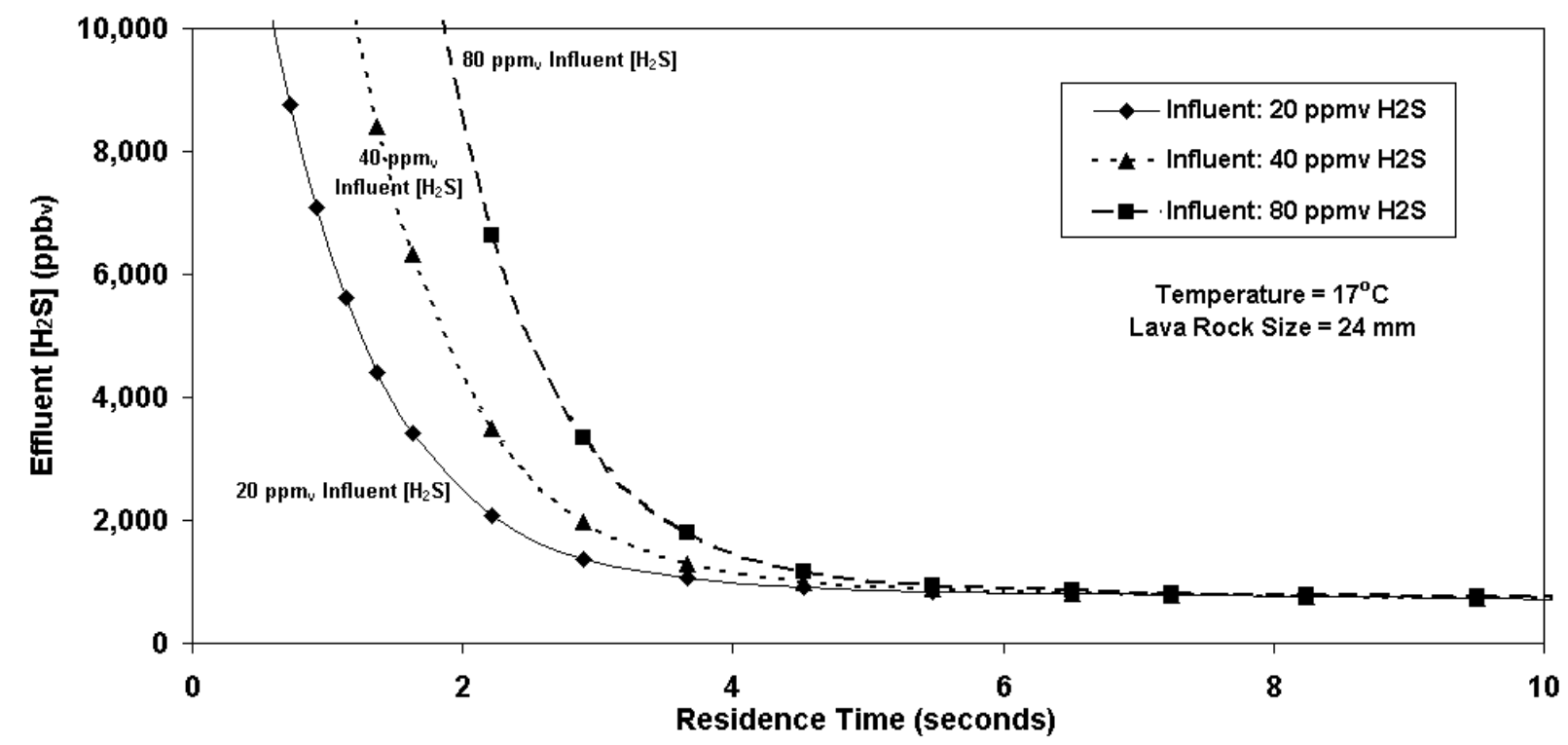

Figure 4.5: Model Simulated Effluent Hydrogen Sulfide Concentration as a Function of Residence Time for Various Influent Hydrogen Sulfide Concentrations. 


\subsubsection{Effluent $\mathrm{H}_{2} \mathrm{~S}$ Concentration as a Function of Residence Time. While}

regulations for the treatment of VOCs may be based on removal efficiency, removal of odorous compounds are often based on the effluent concentration of the odorous compound. Figure 4.5 shows a plot of effluent $\mathrm{H}_{2} \mathrm{~S}$ concentration as a function of residence time for various influent $\mathrm{H}_{2} \mathrm{~S}$ concentrations $\left(20 \mathrm{ppm}_{\mathrm{v}}, 40 \mathrm{ppm}_{\mathrm{v}}\right.$, and $80 \mathrm{ppm}_{\mathrm{v}}$ ) using the model simulation data from Figure 4.4. At residence times below 3 seconds, the higher influent $\mathrm{H}_{2} \mathrm{~S}$ concentration results in a higher effluent $\mathrm{H}_{2} \mathrm{~S}$ concentration. However, after 5 seconds residence time, the effluent $\mathrm{H}_{2} \mathrm{~S}$ concentration decreases to approximately $800 \mathrm{ppb}_{\mathrm{v}}$ for all three concentrations. A further increase in residence time only produces a slight reduction in the effluent $\mathrm{H}_{2} \mathrm{~S}$ concentration. For the average feed conditions, the effluent $\mathrm{H}_{2} \mathrm{~S}$ concentration decreases from approximately 1,100 $\mathrm{ppb}_{\mathrm{v}}$ to $900 \mathrm{ppb}_{\mathrm{v}}$ when residence time is increased from 3.7 seconds to 4.5 seconds; when residence time is increased from 5.5 seconds to 9.5 seconds, the effluent $\mathrm{H}_{2} \mathrm{~S}$ concentration decreases from approximately $800 \mathrm{ppb}_{\mathrm{v}}$ to $700 \mathrm{ppb}_{\mathrm{v}}$.

Figure 4.5 also emphasizes that removal of $\mathrm{H}_{2} \mathrm{~S}$ to the odor detection limit of $0.47 \mathrm{ppb}_{\mathrm{v}}$ (Crites and Tchobanoglous, 1998) with only a lava rock biofilter using the design criteria in Table 4.1 may not be practical; this is based on the model simulations, which show (Figure 4.5) that the minimum achievable effluent concentration is approximately $800 \mathrm{ppb}_{\mathrm{v}}$ at $17^{\circ} \mathrm{C}\left(63^{\circ} \mathrm{F}\right)$. Also, most $\mathrm{H}_{2} \mathrm{~S}$ monitoring meters are not sensitive enough to measure $\mathrm{H}_{2} \mathrm{~S}$ concentrations near the detection limit of $0.47 \mathrm{ppb}_{\mathrm{v}}$. De Zwart and Kuenen (1992) cite an odor threshold range of 8.5 $\mathrm{ppb}_{\mathrm{v}}$ to $1,000 \mathrm{ppb}_{\mathrm{v}}$; the higher value may be due to acclimation because repeated exposure to $\mathrm{H}_{2} \mathrm{~S}$ increases the odor threshold. In addition, a properly exhausted biofilter may allow for dilution of the effluent $\mathrm{H}_{2} \mathrm{~S}$ to non-detectable levels in the surrounding community as the effluent is dispersed from the biofilter exhaust. 


\subsubsection{Minimum Effluent $\mathrm{H}_{2} \mathrm{~S}$ Concentration as a Function of Temperature. Figure}

4.5 highlights another important point: the effluent $\mathrm{H}_{2} \mathrm{~S}$ concentration approaches a minimum value. The effluent $\mathrm{H}_{2} \mathrm{~S}$ concentration cannot drop below a theoretical minimum concentration at a specific temperature. This is based on parameters from the equations describing the kinetic and mass transfer processes. Below a minimum substrate concentration, net biomass growth will not occur because there will be insufficient substrate to maintain biomass growth at a rate higher than biomass loss. The steady-state biofilm mass balance solution (Rittman and McCarty, 2001, p. 215) provides the minimum $\mathrm{H}_{2} \mathrm{~S}$ concentration in the biofilm-phase $\left(\mathrm{S}_{\mathrm{bmin}}\right)$, which can be expressed as follows:

$$
\mathrm{S}_{\mathrm{bmin}}=\left(\mathrm{K}_{\mathrm{s}}\right)\left(\mathrm{k}_{\mathrm{d}}\right) /\left[\left(\mu_{\max }-\mathrm{k}_{\mathrm{d}}\right)\right]
$$

Where

$$
\begin{aligned}
& \mathrm{K}_{\mathrm{s}}=\text { half-saturation constant (moles/volume) } \\
& \mathrm{k}_{\mathrm{d}}=\text { decay coefficient }(1 / \text { time }) \\
& \mu_{\max }=\text { maximum specific growth rate }(1 / \text { time })
\end{aligned}
$$

The steady-state gas-phase minimum $\mathrm{H}_{2} \mathrm{~S}$ concentration $\left(\mathrm{S}_{\min }\right)$, is determine by multiplying the steady-state biofilm-phase minimum $\mathrm{H}_{2} \mathrm{~S}$ concentration $\left(\mathrm{S}_{\mathrm{bmin}}\right)$ by the dimensionless Henry's constant $(\mathrm{H})$ :

$$
\mathrm{S}_{\min }=(\mathrm{H})\left(\mathrm{K}_{\mathrm{s}}\right)\left(\mathrm{k}_{\mathrm{d}}\right) /\left[\left(\mu_{\max }-\mathrm{k}_{\mathrm{d}}\right)\right]
$$

According to the steady-state model solution, $\mathrm{S}_{\min }$ is the lowest achievable effluent concentration. Because $\mathrm{H}$ and $\mu_{\max }$ vary with temperature $\left(\mathrm{K}_{\mathrm{s}}\right.$ and $\mathrm{k}_{\mathrm{d}}$ may also vary with temperature, but the relationship for Acidithiobacillus $s p$. has not been characterized), $\mathrm{S}_{\min }$ can be 
expressed as a function of temperature. Relationships for the temperature corrections of $\mathrm{H}$ and $\mu_{\max }$ are detailed in Martin et al. (2002).

Temperature is one of the most important factors affecting biofilter performance. Figure 4.6 shows $\mathrm{S}_{\min }$ (on a log scale) as a function of temperature using the following parameters which were determined for Solution 1 in Appendix A:

$$
\begin{aligned}
& \mathrm{K}_{\mathrm{s}}=18.0 \mu \mathrm{mol} / \mathrm{L} \\
& \mathrm{k}_{\mathrm{d}}=0.001 \mathrm{hr}^{-1} \\
& \mu_{\max }\left(20^{\circ} \mathrm{C}\right)=0.300 \mathrm{hr}^{-1} \\
& \mathrm{H}\left(20^{\circ} \mathrm{C}\right)=0.379 \text { (dimensionless) }
\end{aligned}
$$

Figure 4.6 shows that $S_{\min }$ decreases exponentially with increasing temperature. However, for a biological reaction, the effluent $\mathrm{H}_{2} \mathrm{~S}$ concentration will not decrease indefinitely with increasing temperature; it will decrease above the optimum temperature (where $\mu_{\max }$ reaches a maximum and above which it decreases). The optimum temperature is probably above $30^{\circ} \mathrm{C}$. Yang and Allen (1994) reported an optimum temperature range of $30^{\circ} \mathrm{C}$ to $40^{\circ} \mathrm{C}$ for a compost biofilter removing $\mathrm{H}_{2} \mathrm{~S}$.

The uncertainty shown in Figure 4.6 is based on the different solution sets determined in Appendix A and using a 20\% uncertainty for $\mathrm{k}_{\mathrm{d}}$ (see Appendix B). Figure 4.6 indicates that $\mathrm{S}_{\min }$ increases significantly with just a small decrease in temperature. At $17^{\circ} \mathrm{C}, \mathrm{S}_{\min }$ is approximately $800 \mathrm{ppb}_{\mathrm{v}} \mathrm{H}_{2} \mathrm{~S}$ (with an uncertainty range of $550 \mathrm{ppb}_{\mathrm{v}} \mathrm{H}_{2} \mathrm{~S}$ to $1,200 \mathrm{ppb}_{\mathrm{v}} \mathrm{H}_{2} \mathrm{~S}$ ) compared to approximately $1,100 \mathrm{ppb}_{\mathrm{v}} \mathrm{H}_{2} \mathrm{~S}$ (with an uncertainty range of $760 \mathrm{ppb}_{\mathrm{v}} \mathrm{H}_{2} \mathrm{~S}$ to $2,000 \mathrm{ppb}_{\mathrm{v}} \mathrm{H}_{2} \mathrm{~S}$ ) at $15^{\circ} \mathrm{C}$. Biofilter performance may be improved by increasing the temperature; at $30^{\circ} \mathrm{C}, \mathrm{S}_{\min }$ decreases to approximately $150 \mathrm{ppb}_{\mathrm{v}} \mathrm{H}_{2} \mathrm{~S}$ (with an uncertainty range of $100 \mathrm{ppb}_{\mathrm{v}} \mathrm{H}_{2} \mathrm{~S}$ to $250 \mathrm{ppb}_{\mathrm{v}}$ $\left.\mathrm{H}_{2} \mathrm{~S}\right)$. 


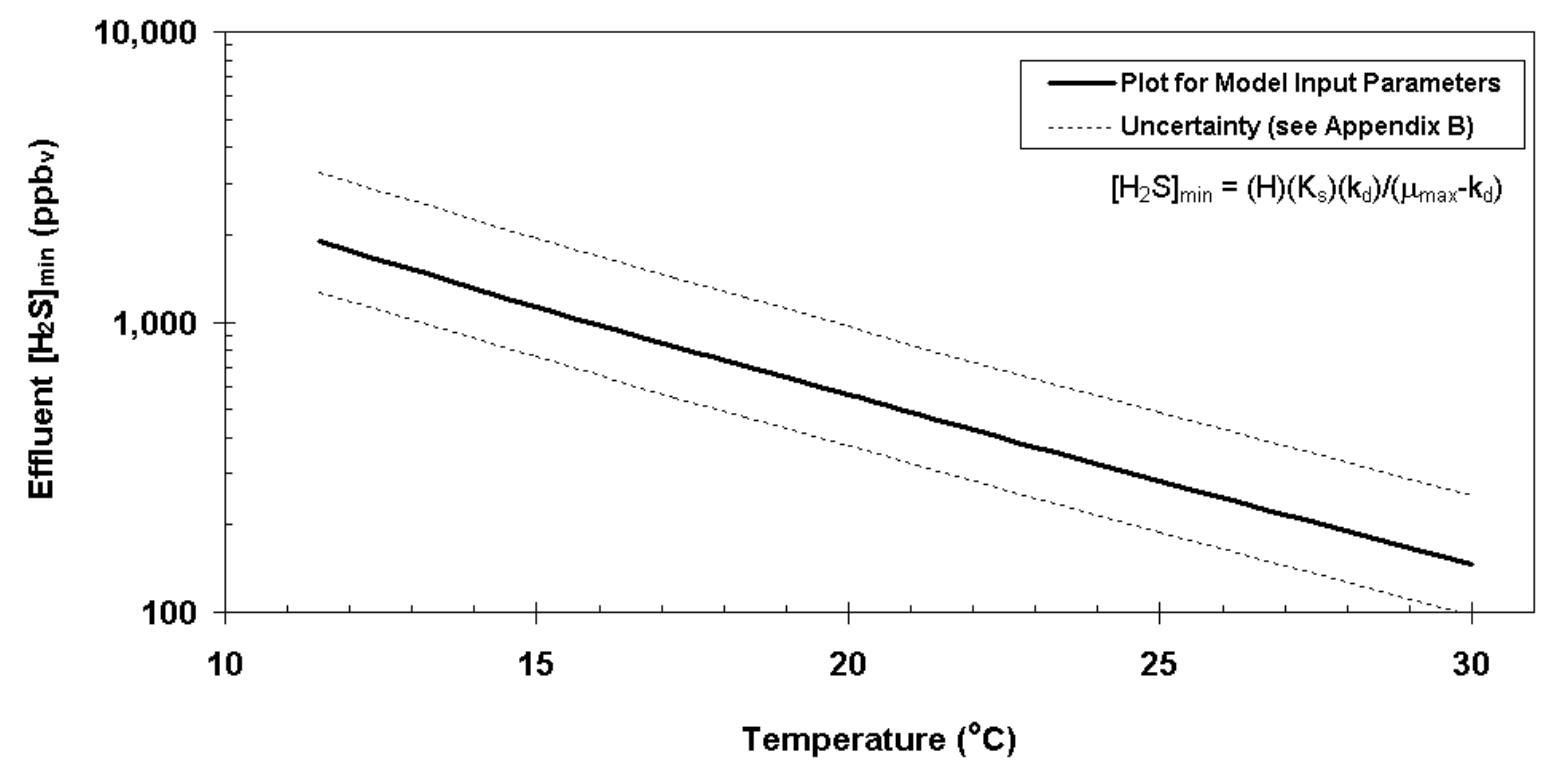

Figure 4.6: Theoretical Steady-state Minimum Effluent Hydrogen Sulfide Concentration as a Function of Temperature.

\subsubsection{Effect of Flow, Bed Area and Depth, and Particle Sizes. Additional model}

simulation plots show that the effluent $\mathrm{H}_{2} \mathrm{~S}$ concentration, $\mathrm{H}_{2} \mathrm{~S}$ removal efficiency, and $\mathrm{EC}_{\max }$ are all independent of the bed depth and bed area and of the feed flow rate when the residence time remains constant (data not shown). However, the particle size has a significant effect on the biofilter performance.

Figure 4.7 shows the model simulated effluent $\mathrm{H}_{2} \mathrm{~S}$ concentration as a function of residence time for various lava rock sizes. Within the size range studied, size does not effect effluent $\mathrm{H}_{2} \mathrm{~S}$ concentration at residence times above 9 seconds. However, effluent $\mathrm{H}_{2} \mathrm{~S}$ concentration increases significantly at residence times below 8 seconds, 5 seconds, and 3 seconds for 48-mm, 24-mm, and 12-mm size lava rock, respectively. Figure 4.7 shows that using a smaller size packing material may improve performance of a biofilter if it has insufficient residence time. For a 2.9-second residence time and 48-mm lava rock, the effluent $\mathrm{H}_{2} \mathrm{~S}$ 
concentration is 4,100 $\mathrm{ppb}_{\mathrm{v}}$. Using 24-mm lava rock will decrease the effluent $\mathrm{H}_{2} \mathrm{~S}$ concentration to $1,400 \mathrm{ppb}_{\mathrm{v}}$ and using 12-mm lava rock will decrease the effluent $\mathrm{H}_{2} \mathrm{~S}$ concentration to $800 \mathrm{ppb}_{\mathrm{v}}$.

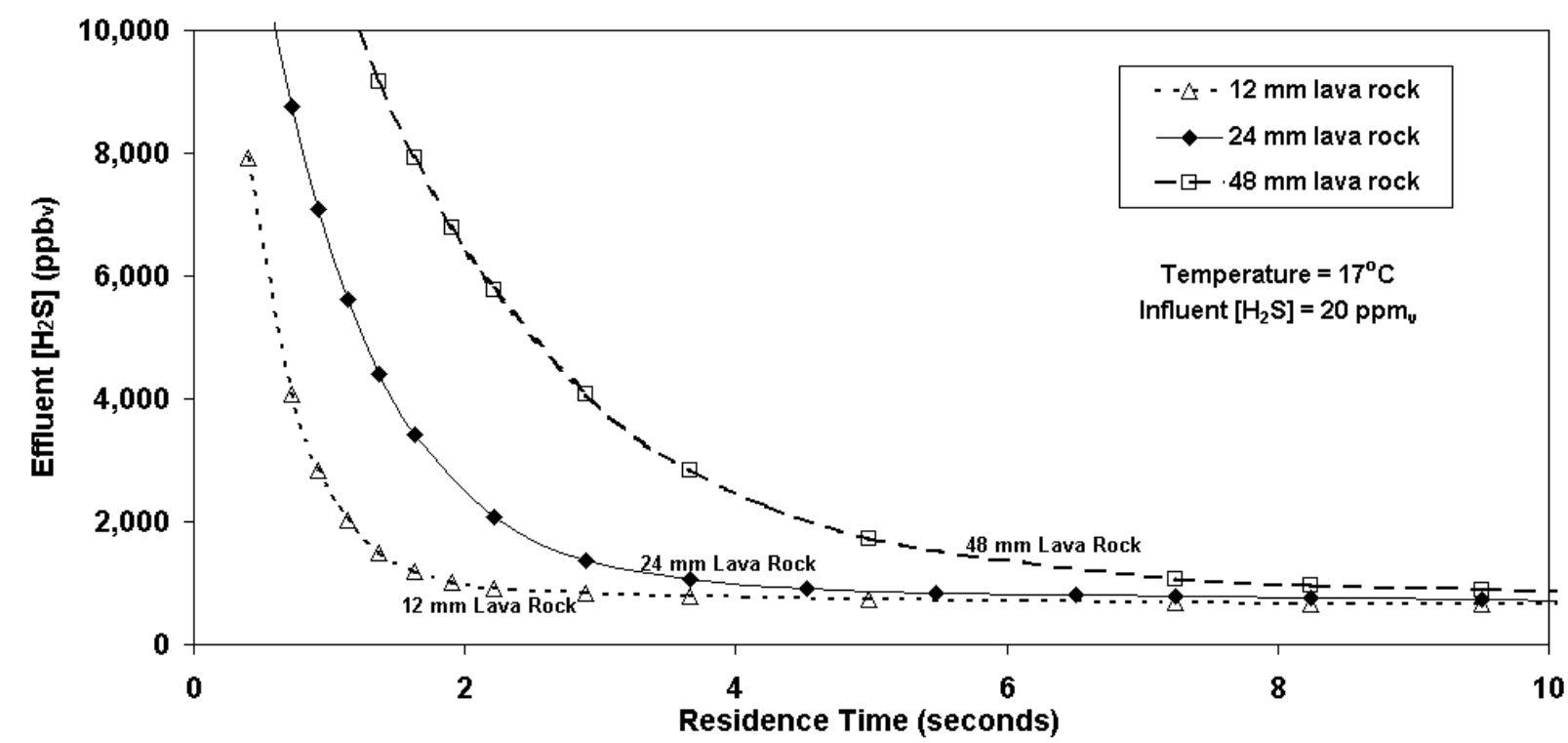

Figure 4.7: Model Simulated Effluent Hydrogen Sulfide Concentration as a Function of Residence Time for Various Lava Rock Sizes.

Although smaller packing material may achieve better $\mathrm{H}_{2} \mathrm{~S}$ removal at low residence times, smaller particles may cause a larger pressure drop across the biofilter bed. For larger particles, the pressure loss across the biofilter bed is relatively small. Yang and Allen (1994) show a pressure drop through a compost biofilter as a function of particle size for several air velocities. The pressure drop ranged from $20 \mathrm{~Pa} / \mathrm{m}$-bed-depth to 35,000 $\mathrm{Pa} / \mathrm{m}$-bed-depth for particle sizes ranging from less than $1.2 \mathrm{~mm}$ to greater than $12 \mathrm{~mm}$ and air velocities ranging from $0.02 \mathrm{~m} / \mathrm{s}$ to $0.28 \mathrm{~m} / \mathrm{s}$. For particles larger than $12 \mathrm{~mm}$, the pressure drop was only $20 \mathrm{~Pa} / \mathrm{m}$ bed-depth at an air velocity of $0.03 \mathrm{~m} / \mathrm{s}$. Large particles (greater than $12 \mathrm{~mm}$ ) showed a much smaller increase in pressure drop with increasing air velocity. 
The pressure drop for a biofilter bed consisting of lava rock is much less than that for a bed of organic packing material. While a pressure gradient helps provide a more uniform flow through the biofilter bed, a large pressure drop may result in insufficient air flow through the bed. Chitwood and Devinny (2001) showed the pressure drop through a 0.76-m deep lava rock biofilter bed as a linear function of flow rate. The pressure drop was $33 \mathrm{~Pa} / \mathrm{m}$-bed-depth at a flow rate of $17 \mathrm{~m}^{3} / \mathrm{min}(0.66 \mathrm{~m} / \mathrm{s}$ approach velocity $)$ for an average particle size of $8 \mathrm{~mm}$; no change in pressure loss or flow rate was noted during rinse water irrigation. Yang and Allen (1994) reported a pressure loss of greater than 2,000 Pa/m-bed-depth for similar sized compost particles at an even lower velocity of $0.28 \mathrm{~m} / \mathrm{s}$.

4.3.7 Effluent $\mathrm{H}_{2} \mathrm{~S}$ Concentration as a Function of Bed Area. Since bed volume (and therefore bed area and bed depth) can be determined from the residence time and the airflow rate, residence time is useful for the general case of varying airflow and bed volume. However, for a specific case where flow and depth are specified (e.g. Table 4.1), it may be more convenient to show effluent $\mathrm{H}_{2} \mathrm{~S}$ concentration as a function of bed area for design sizing purposes. Figure 4.8 shows the model simulated effluent $\mathrm{H}_{2} \mathrm{~S}$ concentration as a function of bed area for 3 different cases of feed conditions and temperature. The conditions are as follows:
A) Case $\mathrm{A}$ is for average feed $\left(283 \mathrm{~m}^{3} / \mathrm{min}\right.$ flow, $\left.20 \mathrm{ppm}_{\mathrm{v}} \mathrm{H}_{2} \mathrm{~S}\right)$ at $17^{\circ} \mathrm{C}$,
B) Case B is for maximum feed $\left(566 \mathrm{~m}^{3} / \mathrm{min}\right.$ flow, $\left.80 \mathrm{ppm}_{\mathrm{v}} \mathrm{H}_{2} \mathrm{~S}\right)$ at $17^{\circ} \mathrm{C}$, and
C) Case $\mathrm{C}$ is for maximum feed $\left(566 \mathrm{~m}^{3} / \mathrm{min}\right.$ flow, $\left.80 \mathrm{ppm}_{\mathrm{v}} \mathrm{H}_{2} \mathrm{~S}\right)$ at $15^{\circ} \mathrm{C}$.

For each case, the bed depth is $1.83 \mathrm{~m}$ and the lava rock size is $24 \mathrm{~mm}$. Figure 4.8 highlights the combined effect that feed conditions and temperature have on the required bed area needed to achieve a target effluent $\mathrm{H}_{2} \mathrm{~S}$ concentration. 
The three plots in Figure 4.8 illustrate that the estimated effluent $\mathrm{H}_{2} \mathrm{~S}$ concentration decreases only very slightly with increasing bed area above $150 \mathrm{~m}^{2}$ for the three cases shown. For the average feed at $17^{\circ} \mathrm{C}$ (Case A) the biofilter requires only $30 \mathrm{~m}^{2}$ of bed area to obtain an effluent $\mathrm{H}_{2} \mathrm{~S}$ concentration below $1,000 \mathrm{ppb}_{\mathrm{v}}$ and $42 \mathrm{~m}^{2}$ of bed area to obtain an effluent $\mathrm{H}_{2} \mathrm{~S}$ concentration below $800 \mathrm{ppb}_{\mathrm{v}}$. For the maximum feed at $17^{\circ} \mathrm{C}$ (Case B) the biofilter requires 70 $\mathrm{m}^{2}$ of bed area to obtain an effluent $\mathrm{H}_{2} \mathrm{~S}$ concentration below $1,000 \mathrm{ppb}_{\mathrm{v}}$ and $117 \mathrm{~m}^{2}$ of bed area to obtain an effluent $\mathrm{H}_{2} \mathrm{~S}$ concentration below $800 \mathrm{ppb}_{\mathrm{v}}$. However, above $140 \mathrm{~m}^{2}$ of bed area, both the average feed (Case A) and the maximum feed (Case B) conditions result in comparable effluents (below $700 \mathrm{ppb}_{\mathrm{v}}$ ) at $17^{\circ} \mathrm{C}$. For the most difficult treatment conditions of maximum feed at $15^{\circ} \mathrm{C}$ (Case $\mathrm{C}$ ), even $150 \mathrm{~m}^{2}$ of bed area will not attain an effluent $\mathrm{H}_{2} \mathrm{~S}$ concentration below $1,000 \mathrm{ppb}_{\mathrm{v}}$, which is below $\mathrm{S}_{\min }$ (see Figure 4.6).

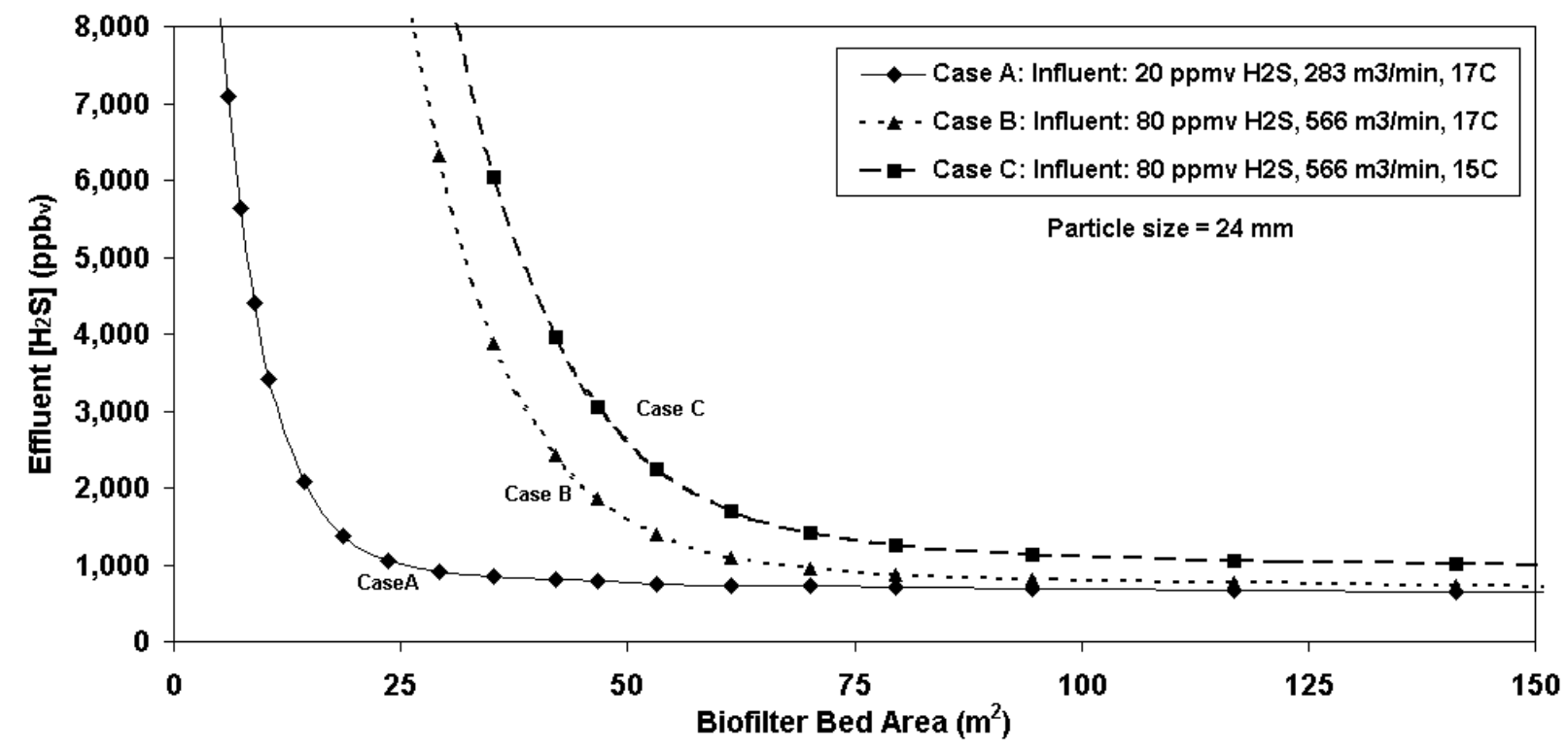

Figure 4.8: Model Simulated Effluent Hydrogen Sulfide Concentration as a Function of Biofilter Bed Area for Various Operational Conditions. 
4.3.8 Dynamic Response to Feed Concentration Step Increase. In the previous plots, the model simulations were run for 365 days with constant loading to attain steady state conditions. However, most biofilters do not run at steady-state conditions and are sensitive to loading spikes. Therefore, it is important to examine the biofilter response to dynamic conditions such as sharp increases in influent $\mathrm{H}_{2} \mathrm{~S}$ concentration.

Figure 4.9 shows the model simulated effluent $\mathrm{H}_{2} \mathrm{~S}$ concentration as a function of time from start-up for a step increase in influent $\mathrm{H}_{2} \mathrm{~S}$ concentration for various combinations of flow and bed area. The influent $\mathrm{H}_{2} \mathrm{~S}$ concentration increases from $10 \mathrm{ppb}_{\mathrm{v}}$ to $80 \mathrm{ppb}_{\mathrm{v}}$ after 300 days and returns to $10 \mathrm{ppb}_{\mathrm{v}}$ ten days later. The biofilter conditions for this simulation are as follows:

1) Case 1 is for average flow $\left(283 \mathrm{~m}^{3} / \mathrm{min}\right)$ through an undersized $\left(42 \mathrm{~m}^{2}\right)$ biofilter bed with $\tau=6.5 \mathrm{sec}$,

2) Case 2 is for maximum flow $\left(566 \mathrm{~m}^{3} / \mathrm{min}\right)$ through an undersized $\left(42 \mathrm{~m}^{2}\right)$ biofilter bed with $\tau=3.3 \mathrm{sec}$,

3) Case 3 is for average flow $\left(283 \mathrm{~m}^{3} / \mathrm{min}\right)$ through a sufficiently sized $\left(117 \mathrm{~m}^{2}\right)$ biofilter bed with $\tau=18.1 \mathrm{sec}$, and

4) Case 4 is for maximum flow $\left(566 \mathrm{~m}^{3} / \mathrm{min}\right)$ through a sufficiently sized $\left(117 \mathrm{~m}^{2}\right)$ biofilter bed with $\tau=9.1 \mathrm{sec}$.

For each case, the temperature is $15^{\circ} \mathrm{C}$, the lava rock size is $24 \mathrm{~mm}$, and the bed depth is $1.83 \mathrm{~m}$. Bed areas of $42 \mathrm{~m}^{2}$ and $117 \mathrm{~m}^{2}$ were chosen from Figure 4.8 as the areas required to obtain an effluent $\mathrm{H}_{2} \mathrm{~S}$ concentration below $800 \mathrm{ppb}_{\mathrm{v}}$ for the average (Case A) and maximum (Case B) feed at $17^{\circ} \mathrm{C}$, respectively. The simulations were run at $15^{\circ} \mathrm{C}$ as a worst-case scenario.

Figure 4.9 shows that for each case, the effluent $\mathrm{H}_{2} \mathrm{~S}$ concentration increases sharply, then drops in response to the step increase in influent $\mathrm{H}_{2} \mathrm{~S}$ concentration. The greatest increase 
in effluent $\mathrm{H}_{2} \mathrm{~S}$ concentration is for the maximum flow through the undersized bed (Case 2). For average flow through the undersized bed (Case 1), the effluent $\mathrm{H}_{2} \mathrm{~S}$ concentration increases from $1,000 \mathrm{ppb}_{\mathrm{v}}$ to nearly $9,000 \mathrm{ppb}_{\mathrm{v}} \mathrm{H}_{2} \mathrm{~S}$, decreasing to $3,200 \mathrm{ppb}_{\mathrm{v}} \mathrm{H}_{2} \mathrm{~S}$ within 10 days. For maximum flow through the undersized bed (Case 2), the effluent $\mathrm{H}_{2} \mathrm{~S}$ concentration increases from $1,400 \mathrm{ppb}_{\mathrm{v}}$ to over $12,000 \mathrm{ppb}_{\mathrm{v}} \mathrm{H}_{2} \mathrm{~S}$, then deceases to $5,900 \mathrm{ppb}_{\mathrm{v}} \mathrm{H}_{2} \mathrm{~S}$ within 10 days. The effluent $\mathrm{H}_{2} \mathrm{~S}$ concentration for maximum flow through the undersized bed (Case 2) before the step increase is much higher than for the other cases. This indicates that the bed area is too small for the maximum flow condition.

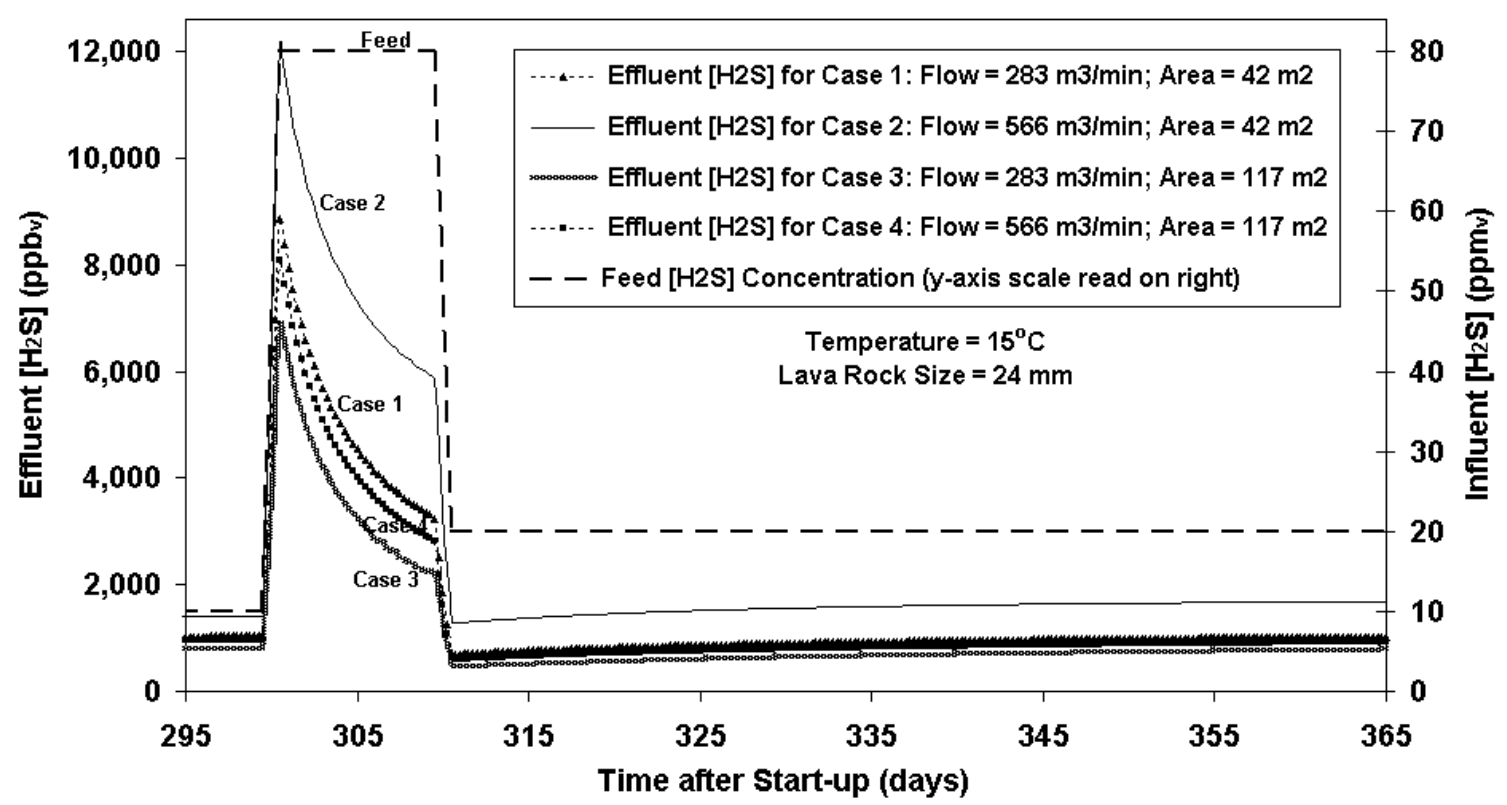

Figure 4.9: Model Simulated Effluent Hydrogen Sulfide Concentration as a Function of Elapsed Time After Start-up: Response to a Spike in Feed Hydrogen Sulfide Concentration for Various Operational Conditions.

Increasing the bed area from $42 \mathrm{~m}^{2}$ to $117 \mathrm{~m}^{2}$ decreases the effluent $\mathrm{H}_{2} \mathrm{~S}$ concentration response for both the average and maximum flow, but the decrease is most dramatic for the cases 
of maximum flow (Case 2 and Case 4). For the maximum flow through a properly sized bed (Case 4), the effluent $\mathrm{H}_{2} \mathrm{~S}$ concentration increases from 900 to $8,100 \mathrm{ppb}_{\mathrm{v}} \mathrm{H}_{2} \mathrm{~S}$, then decreases to 2,800 $\mathrm{ppb}_{\mathrm{v}} \mathrm{H}_{2} \mathrm{~S}$ within 10 days. This shows how a sharp influent concentration increase will pass through the biofilter as an effluent spike and the effluent spike will be higher for an undersized bed.

Also, Figure 4.8 shows that the effluent $\mathrm{H}_{2} \mathrm{~S}$ concentration will return to a low value immediately after the influent spike passes through the biofilter. In fact, the effluent concentration is lower immediately after the completion of the step increase than before it. This is due to the increase in active biomass concentration in the biofilm after the step increase (data not shown). The higher substrate concentration during the step increase allows for greater biomass growth.

4.3.9 Biofilter Construction and Operation. Typically, biofilters have a rectangular or cylindrical shape although non-rectangular shapes can also be used when there is a space constraint. An existing tank (such as a clarifier) may also be used. The biofilter may be enclosed or have an open outlet with the bed directly exposed to the atmosphere. It is crucial to use construction material that is resistant to corrosion by $\mathrm{H}_{2} \mathrm{~S}$ and sulfuric acid or to use a durable protective coating. The absence of corners in a cylindrical biofilter will provide better air distribution, but may be more difficult to fit a liner to; alternatively, a spray-on coating may be used to line the tank. An air distribution system should collect the contaminated air from the source and distribute it evenly through the biofilter.

Air conveyance may be by forced draft (with the blower at the influent) or induced draft (with the blower at the effluent), although induced draft can only be used with a closed biofilter. The contaminated air is typically top-loaded (down-flow of the contaminated air through the 
biofilter) or bottom-loaded (up-flow), although horizontal flow has been used and step feed and forward feed may be feasible (Lee et al., 2001). An open outlet biofilter cannot be used for horizontal flow or down-flow. In an up-flow lava rock biofilter used for $\mathrm{H}_{2} \mathrm{~S}$ removal, the $\mathrm{pH}$ will be lowest at the bottom of the biofilter bed because the biomass concentration is highest where the $\mathrm{H}_{2} \mathrm{~S}$ concentration is highest (at the influent). Unlike organic bed media, lava rock requires nutrient addition for microbial growth. This is typically done by irrigating the bed with water containing the required nutrients; the water also provides essential moisture. Cedar Rapids WPCF uses spray nozzles to deliver clarified carbonaceous activated sludge effluent providing nutrients and moisture as well as removing the sulfuric acid from the bed (Martin et al., 2002). Devinney et al. (pp. 149-174) provide a more detailed description for full-scale biofilter design.

Figure 4.6 and Figure 4.8 show that temperature has a significant influence on biofilter performance. Hence, it is important to maintain a temperature in the biofilter as close to the design temperature as possible. The biofilter cover, air feed ducts, and rinse water feed pipes should all be well insulated, especially in cooler climates. Also, the bed portion of the biofilter can be located below ground or insulated by adding an earth embankment. Increasing the bed temperature may be achieved either by heating the feed air or heating the rinse water feed. However, heating the feed air will decrease the relative humidity of the air, potentially drying out the biofilter bed.

Model simulations show that as the biofilter temperature increases, the biofilter reaches the optimum removal efficiency more rapidly, indicating that a summer start-up of a biofilter would proceed more rapidly (data not shown). This is due to more rapid biofilm development resulting from faster growth of the microorganisms at higher temperatures. Also, inoculating a biofilter (e.g. with raw sewage, activated sludge, consortia from food processing industry, or lab 
cultivated microorganisms) may result in a faster start-up but generally does not effect the longterm performance of the biofilter (Devinney et al., 1999, pp. 83-84, 187). Since the exact origin of the microorganisms in a lava rock biofilter is unknown (e.g. sewage, lava rock, or elsewhere) and inoculation does not ensure that the inoculum will adhere to the lava rock, inoculation may not be so simple and straightforward. Sewage is one possible source of inoculum but pathogens may be a concern and solids, oil, and grease should be removed to prevent biofilter bed fouling and clogging. Another source of inoculum is the rinse water from an existing lava rock biofilter. Since the concentration of microorganisms in the rinse water may be very dilute it may be beneficial to concentrate them (e.g. using a centrifuge).

4.3.10 Biofilter Configuration. Although the capital cost may be less for a single biofilter, using two smaller biofilters allows for greater operational flexibility. Using two biofilters in parallel allows for the isolation of an individual bed for maintenance or during shut down without interrupting the flow through the other bed. For example, the model predicts that for average design conditions ( $20 \mathrm{ppm}_{\mathrm{v}}$ feed $\mathrm{H}_{2} \mathrm{~S}$ concentration, $283 \mathrm{~m}^{3} / \mathrm{min}$ air flow, $17^{\circ} \mathrm{C}$ temperature) shown in Case A of Figure 4.8, the effluent $\mathrm{H}_{2} \mathrm{~S}$ concentration will be $800 \mathrm{ppb}_{\mathrm{v}}$ for two $21-\mathrm{m}^{2}$ biofilters ( $42 \mathrm{~m}^{2}$ total area) in parallel. If, during maintenance, the feed is switched from both of the $21 \mathrm{~m}^{2}$ biofilters to a single $21 \mathrm{~m}^{2}$ biofilter, the estimated effluent $\mathrm{H}_{2} \mathrm{~S}$ concentration will only increase from $800 \mathrm{ppb}_{\mathrm{v}}$ to $1,100 \mathrm{ppb}_{\mathrm{v}}$. However, if maximum feed and low temperature ( $80 \mathrm{ppm}_{\mathrm{v}}$ feed $\mathrm{H}_{2} \mathrm{~S}$ concentration, $566 \mathrm{~m}^{3} / \mathrm{min}$ air flow, $15^{\circ} \mathrm{C}$ temperature) is anticipated, the biofilter area may be sized at $140 \mathrm{~m}^{2}$ for the "worst-case" scenario (Case C in Figure 4.8). Sizing two biofilters in parallel at $70 \mathrm{~m}^{2}$ each $\left(140 \mathrm{~m}^{2}\right.$ total area) will provide treatment to $1,400 \mathrm{ppb}_{\mathrm{v}}$ in a single bed compared to $1,000 \mathrm{ppb}_{\mathrm{v}}$ using both beds for maximum feed and minimum temperature design conditions. 
Another advantage to using two smaller biofilters is the flexibility to use the two biofilters in series if necessary in future operation. A biofilter configuration with beds operated in series allows each individual bed to treat different contaminants. This type of biofilter has been used successfully to remove both $\mathrm{H}_{2} \mathrm{~S}$ and VOCs combined in a single air stream (Chitwood et al., 1999; Ruokojarvi et al., 2001; and Li et al., 2003). Removal of both $\mathrm{H}_{2} \mathrm{~S}$ and VOCs is difficult in a single-bed biofilter because the oxidation of $\mathrm{H}_{2} \mathrm{~S}$ generates sulfuric acid and the declining $\mathrm{pH}$ inhibits the organisms that degrade compounds other than $\mathrm{H}_{2} \mathrm{~S}$; after $\mathrm{H}_{2} \mathrm{~S}$ is removed in the first biofilter, a second biofilter can be used to remove other reduced sulfur compounds and VOCs at neutral pH (Li et al., 2003). Chitwood et al. (1999) used a two-stage biofilter, the first stage containing lava rock and operating at a low $\mathrm{pH}$ and the second stage containing wood chips operating at neutral $\mathrm{pH}$, to treat a mixed air stream of $\mathrm{H}_{2} \mathrm{~S}$ and VOCs. Another possible biofilter configuration, is cycled switching of two beds in series. This involves feeding odorous air to bed 1 with the treated effluent from bed 1 being fed to bed 2 . At the end of the cycle, the feed is switched and odorous air is first fed to bed 2 and the treated effluent from bed 2 is fed to bed 1 . This may allow for higher biomass concentration throughout the entire bed depth in both biofilters. The higher biomass concentration may also provide for better treatment of shock loads. A more detailed model simulation could be used to estimate the switching frequency although pilot testing would be required to verify this. Directional switching in a single bed has been examined for the control of moisture and biomass growth (Kinney et al., 1996 and Sabo et al. 1996, p. 63).

Although two beds in parallel or series or with cycled switching may provide more flexibility and possibly improved treatment, they will have a higher capital cost, will be more complex to operate, and will have larger head losses. The final choice of bed configuration must 
be based on a detailed cost analysis, which includes evaluating the benefit and likelihood of potential change in conditions.

\subsection{CONCLUSIONS}

1. For the design and performance evaluation of biofilters used for removing odorous compounds, it may be more useful to express the performance in terms of effluent concentration rather than removal efficiency or elimination capacity. Bed volume (or area for a constant bed depth) may be more convenient than residence time for sizing the biofilter if the airflow is constant.

2. A conventional biofilter will be limited to a minimum effluent concentration. Increasing residence time, increasing bed area or volume, or decreasing loading or flow will not reduce the effluent concentration below that minimum effluent concentration. However, the minimum effluent concentration is a function of temperature and will decrease with increasing temperature (up to the optimum temperature). For the model calibration values outlined in this study, the minimum effluent concentration decreased from 1,100 $\mathrm{ppb}_{\mathrm{v}} \mathrm{H}_{2} \mathrm{~S}$ to $800 \mathrm{ppb}_{\mathrm{v}} \mathrm{H}_{2} \mathrm{~S}$ when the temperature was increased from $15^{\circ} \mathrm{C}$ to $17^{\circ} \mathrm{C}$.

3. The effluent concentration from a biofilter may approach the minimum effluent concentration by increasing the residence time. At sufficiently long residence times, further reduction in the residence time will only result in a slight reduction in the effluent $\mathrm{H}_{2} \mathrm{~S}$ concentration. For the average feed conditions in this study, the effluent $\mathrm{H}_{2} \mathrm{~S}$ concentration decreases by $140 \mathrm{ppb}_{\mathrm{v}}$ when 
the residence time is increased from 3.7 to 4.5 seconds; when residence time is increased from 5.5 seconds to 9.5 seconds, the effluent $\mathrm{H}_{2} \mathrm{~S}$ concentration decreases by only $100 \mathrm{ppb}_{\mathrm{v}}$.

4. Reducing the packing material size may improve performance for a biofilter that has insufficient residence time. Replacing $48 \mathrm{~mm}$ size lava rock with $12 \mathrm{~mm}$ size lava rock for a biofilter with a 2.9 second residence time at the average feed conditions in this study reduces the effluent $\mathrm{H}_{2} \mathrm{~S}$ concentration from $4,100 \mathrm{ppb}_{\mathrm{v}}$ to $800 \mathrm{ppb}_{\mathrm{v}}$.

5. Shock loading can significantly increase the final effluent $\mathrm{H}_{2} \mathrm{~S}$ concentration above that predicted by steady-state model simulations. Large influent concentration increases will pass through the biofilter as an effluent spike and this spike will be higher for an undersized bed. To consistently meet treatment objectives, dynamic feed conditions should be considered as well as the combination of low temperature and high flow and feed concentration.

6. Biofilter ${ }^{\mathrm{TM}}$ can serve as a valuable tool in the design and performance optimization of biofilters.

\subsection{REFERENCES}

Biofilter $^{\mathrm{TM}}$ : Biofilter Model Software, Design Option Tool, Version 1.1 (April, 2002) Authors: Crittenden, J.C.; Mihelcic, J.R.; Li, H.; Oman, E.; and Hautakangas, H. Michigan Technological University, National Center for Clean Industrial and Treatment Technologies Environmental Technologies.

Chitwood, D.E.; Devinny, J.S.; and Reynolds, E.F. (1999) Evaluation of a Two-Stage Biofilter for Treatment of POTW Waste Air. Env. Prog., 18, 212-221. 
Chitwood, D.E., and Devinny, J.S. (2001) Treatment of a Mixed Hydrogen Sulfide and Organic Vapors in a Rock Medium Biofilter. Water Env. Res., 73(4), 426-435.

Cox, H.H.J., and Deshusses, M.A. (1999) Biomass Control in Waste Air Biotrickling Filters by Protozoan Predation. Biotechnol. Bioengrg., 62, 216-224.

Crites, R., and Tchobanoglous, G. (1998) Small and DeCentralized Wastewater Management Systems, WCB McGraw-Hill, Boston.

Dechant, D; Ball, P.; and Hatch C. (1999) Full Scale Validation of Emerging Bioscrubber Technology for Odor Control. Proc. Water Environ. Fed. $72^{\text {nd }}$ Annu. Conf. Exposition [CDROM], New Orleans, La.

Deshusses, M.A.; Hamer, G.; and Dunn, I.J. (1995) Behavior of Biofilters for Waste Air Biotreatment. 1. Dynamic Model Development. Environ. Sci. Technol., 29, 1048-1058.

Devinny, J.S.; Deshusses, M.A.; and Webster, T.S. (1999) Biofiltration for Air Pollution Control. Lewis Publishers, Boca Raton, FL.

De Zwart, J.M.M., and Kuenen, J.G. (1992) C - $_{1}$ cycle of Sulfur Compounds. Biodegradation 3, 37-59.

Fortin, N.Y., and Deshusses, M.A. (1999a) Treatment of Methyl tert-Butyl Ether Vapors in Biotrickling Filters. 1. Reactor Startup, Steady-State Performance, and Culture Characteristics. Environ. Sci. Technol., 33(17), 2980-2986.

Fortin, N.Y., and Deshusses, M.A. (1999b) Treatment of Methyl tert-Butyl Ether Vapors in Biotrickling Filters. 2. Analysis of the Rate-Limiting Step and Behavior under Transient Conditions. Environ. Sci. Technol., 33(17), 2987-2991. 
Hautakangas, H; Mihelcic, J.R.; Crittenden, J.C.; and Oman, E.J. (1999) Optimization and Modeling of Biofiltration for Odor Control. Proc. Water Environ. Fed. $72^{\text {nd }}$ Annu. Conf. Exposition [CD-ROM], New Orleans, La.

Kinney, K.A.; Chang, D.P.Y.; Schroeder, E.D.; and Scow, K.M. (1996) Performance of a Directionally-switching Biofilter Treating Toluene Contaminated Air" Proc. Air Waste Mgmnt. Assn. 89th Annu. Meeting Exhibition, Pittsburgh, PA.

Lee, D.H.; Lau, A.K.; and Pinder, K.L. (2001) Development and Performance of an Alternative Biofilter System. J. Air Waste Mgmnt. Assn., 51, 78-85.

Li, H. (2002) Modeling and Optimization of Biofiltration for Odor Control, $\mathrm{PhD}$ dissertation, Michigan Technological University, Houghton, MI.

Li, H.; Crittenden, J.C.; Mihelcic, J.R.; and Hautakangas, H. (2002) Optimization of Biofiltration for Odor Control: Model Development and Parameter Sensitivity, Water Environ. Res., 72(1), 516.

Li, H.; Mihelcic, J.R.; Crittenden, J.C.; and Anderson, K.A. (2003) Field Measurements and Modeling of a Two-Stage Biofilter that Treats Odorous Sulfur Emissions. J. Environ. Eng., in press.

Martin, R.W.; Li., H.; Mihelcic, J.R.; Crittenden, J.C.; Lueking, D.R.; Hatch, C.R.; and Ball, P. (2002) Optimization of Biofiltration for Odor Control: Model Verification and Applications. Water Environ. Res., 72(1), 17-27.

Morton, R., and Caballero, R. (1996) The Biotrickling Story. Water Environ. Technol., 8, 39-45.

Rittman, B.E., and McCarty, P.L. (2001) Environmental Technology: Principles and Applications. McGraw-Hill, Boston, Ma. 
Ruokojarvi, A.; Ruuskanen, J.; Martikaninen, P.J.; and Olkkonen, M. (2001) Oxidation of Gas Mixtures Containing Dimethyl Sulfide, Hydrogen Sulfide, and Methanethiol Using a Two-stage Biotrickling Filter. J. Air Waste Mgmnt. Assn., 51, 11-16.

Sabo, F.; Schneider, T.; and Motz, U. (1996) Latest Developments and Industrial Applications of Biofiltration. Proc. 1996 Conference on Biofiltration (an Air Pollution Control Technology), Reynolds, F.E., editor, Reynolds Group, Tustin, CA.

Schowengerdt, R.W.; Hunter, B.; and Hanson, R.E. (1999) Incremental Hydrogen Sulfide Loading and Diurnal Fluctuation of Three Operating Biofilters. Proc. Water Environ. Fed. $72^{\text {nd }}$ Annu. Conf. Exposition [CD-ROM], New Orleans, La.

Shareefdeen, Z.; Baltzis, B.C.; Oh, Y.S.; and Bartha, R. (1993) Biofiltration of Methanol Vapor. Biotechnol. Bioengrg. 41,512-524.

Sorensen, H.W.; Bruciak, J.; Gomez, G.G.; and Ocanas, R. (2000) Engineer-Operator Team Develops a Cost-Effective System Wide Odor Control Program for the Extremely High Sulfide Concentrations in the City of Brownsville, Texas. Proc. Water Environ. Fed. $73^{\text {rd }}$ Annu. Conf. Exposition [CD-ROM], Anaheim, Ca.

Swanson, W.J., and Loehr, R.C. (1997) Biofiltration: Fundamentals, Design, and Operations Principles, and Applications. J. Env Engrg., 123(6):538-546.

Torres, E.M.; Devinny, J.; Basrai, S.S.; Carson, L.J.; Gossett, R.; Kogan, V.; Ahn, T.; Kardos, D.; Webster, T.; and Stolin, B. (1979) Biofiltration: Controlling Air Emissions Through Innovative Technology. Water Environment Research Foundation, Project 92-VOC-1.

Vaith, K.; Cannon, M.; Milligan, D.; and Heydown, J. (1996) Comparing Scrubbing Technologies. Water Environ. Technol., June, 35-38. 
Vic, T.E. (2001) Wastewater Treatment Plant Odor Control Using a Lava Rock Based Biofilter. $74^{\text {th }}$ Annu. Central States Water Environ. Assoc. Conf., La Crosse, Wi.

Wallis, M.; Witherspoon, J.; Suzuki, S.; Card, T.R.; Mayer, G.; and Chang, D.P.Y. (1996) A Critical Review of Odor Control Equipment for Toxic Air Emissions Reduction, Project 91VOC-2, Water Environment Research Foundation, Alexandria, Va.

Wani, A.H.; Branion, R.M.R.; and Lau, A.K. (1998) Effects of Periods of Starvation and Fluctuating of Hydrogen Sulfide Concentration on Biofilter Dynamics and Performance. $J$. Hazardous Materials, 60, 287-303.

Wong, E.; Velez, S.I.; and Greer, G. (1999) Effective Odor Control Techniques in Lee County Sewer Systems. Proc. Water Environ. Fed. $72^{\text {nd }}$ Annu. Conf. Exposition [CD-ROM], New Orleans, La.

Yang, Y., and Allen, E.R. (1994) Biofiltration Control of Hydrogen Sulfide. 1. Design and Operational Parameters. J. Air Waste Mgmt. Assn., 44, 863-868. 


\section{CHAPTER 5}

\section{CONCLUSIONS AND RECCOMENDATIONS}

\subsection{CONCLUSIONS:}

Chapter 1, Conclusion 1: Chemoautotrophic bacteria play an important role in wastewater treatment processes. Nitrifying bacteria are responsible for the removal of ammonia and nitrogen from wastewater and various Acidithiobacillus sp. have been shown to remove hydrogen sulfide from odorous air.

2.1 Dye-bearing wastewater containing the azo dye acid black 1 (AB1) inhibited nitrification at concentrations as low $24 \mathrm{mg} \mathrm{AB1/L}$. The combined effect of low temperature and dye-bearing wastewater caused complete nitrification failure at $7^{\circ} \mathrm{C}$ while nitrification inhibition at $22^{\circ} \mathrm{C}$ was less, but still significant: $97.0 \% \mathrm{NH}_{3}$ removal for $73 \mathrm{mg} \mathrm{AB} 1 / \mathrm{L}$ compared to $99.9 \%$ for the $22^{\circ} \mathrm{C}$ control.

2.2 Ammonia $\left(\mathrm{NH}_{3}\right)$ and chemical oxygen demand (COD) removal declined in all reactors fed $\mathrm{AB} 1$ with the performance decline occurring sooner as the concentration of $\mathrm{AB} 1$ increased. For $24 \mathrm{mg} \mathrm{AB1} / \mathrm{L}, 49 \mathrm{mg} \mathrm{AB1} / \mathrm{L}$, and $73 \mathrm{mg} \mathrm{AB1} / \mathrm{L}$, the nitrification failure occurred in 52 days, 45 days, and 38 days after start-up, respectively.

2.3 Decreasing $\mathrm{AB} 1$ loading at $7^{\circ} \mathrm{C}$ led to partial nitrification recovery within one week as indicated by significant nitrate production and a slight improvement in COD removal. There was no corresponding increase in $\mathrm{NH}_{3}$ removal, however. 
2.4 The presence of AB1-bearing wastewater led to additional deterioration. COD removal decreased at $7^{\circ} \mathrm{C}$ and $22^{\circ} \mathrm{C}$; effluent TSS increased at $7^{\circ} \mathrm{C}$; endogenous and exogenous oxygen uptake decreased and foaming increased at $7^{\circ} \mathrm{C}$.

2.5 The combination of $\mathrm{AB} 1$ and low temperature caused poor effluent quality at $7^{\circ} \mathrm{C}$, emphasizing that potential inhibitors must be investigated at the lowest WWTP operating temperature.

3.1 A dynamic biofilter model predicting the removal of hydrogen sulfide $\left(\mathrm{H}_{2} \mathrm{~S}\right)$ in biofilters was calibrated and validated using pilot-scale and full-scale data. The model calibration simulation agreed well with the actual pilot-scale data. The model validation simulations of the pilot- and full-scale biofilter also agreed well with actual data. The model used in this study has been incorporated into a user-friendly software package (Biofilter $\left.{ }^{\mathrm{TM}}\right)$.

3.2 Model simulations of the full-scale biofilter using the parameters determined from the model calibration illustrate the influence of gas residence time, influent concentration, temperature, and changes in influent concentration on biofilter performance and design.

3.3 Model simulations showed that the lava rock biofilter should provide at least 5 seconds of residence time to achieve a treatment objective of $0.5 \mathrm{ppm}_{\mathrm{v}}$; the time the biofilter takes to achieve the steady-state treatment objective of $0.5 \mathrm{ppm}_{\mathrm{v}}$ increases from less than 1 day to 2 to 3 days as the temperature is decreased from 25 to $15^{\circ} \mathrm{C}$.

3.4 Model simulations indicated that it is useful to consider the influent concentration in biofilter design. 
3.5 Model simulations also showed the need to consider the maximum influent concentration instead of the average influent concentration when sizing a biofilter.

4.1 Biofilter ${ }^{\mathrm{TM}}$ is a valuable tool for the design and performance evaluation of biofilters.

4.2 Expressing performance in terms of effluent concentration rather than removal efficiency or elimination capacity may be more useful in the design and performance evaluation of biofilters. Bed volume may be more convenient than residence time for sizing the biofilter receiving constant airflow.

4.3 Increasing residence time, bed area, or volume, or decreasing loading or flow will not reduce the effluent concentration below the minimum effluent concentration. However, the minimum effluent concentration decreases with increasing temperature (up to the optimum temperature).

4.4 Increasing the biofilter residence time may result in the effluent concentration approaching the minimum effluent concentration. A further reduction in the residence time will only result in a slight reduction in the effluent $\mathrm{H}_{2} \mathrm{~S}$ concentration at higher residence times. For the average feed conditions in this study, the effluent $\mathrm{H}_{2} \mathrm{~S}$ concentration decreases by $140 \mathrm{ppb}_{\mathrm{v}}$ when the residence time is increased from 3.7 to 4.5 seconds; when residence time is increased from 5.5 seconds to 9.5 seconds, the effluent $\mathrm{H}_{2} \mathrm{~S}$ concentration decreases by only $100 \mathrm{ppb}_{\mathrm{v}}$.

4.5 For a biofilter that has insufficient residence time, reducing packing material size may improve performance. For a biofilter with a 2.9 second residence time at the average feed conditions in this study, effluent $\mathrm{H}_{2} \mathrm{~S}$ concentration was reduced the from $4,100 \mathrm{ppb}_{\mathrm{v}}$ to $800 \mathrm{ppb}_{\mathrm{v}}$ by replacing $48 \mathrm{~mm}$ size lava rock with $12 \mathrm{~mm}$ size lava rock. 
4.6 Shock loading significantly increased the final effluent $\mathrm{H}_{2} \mathrm{~S}$ concentration above that predicted by steady-state model simulations. Large influent concentration increases will pass through the biofilter as an effluent spike and this spike will be higher for an undersized bed. To consistently meet treatment objectives, dynamic feed conditions should be considered as well as the combination of low temperature and high flow and feed concentration.

\subsection{RECOMMENDATIONS:}

1. Performing additional nitrification inhibition studies using AB1 (instead of industrial dyeing discharge) and run at varying substrate $\left(\mathrm{NH}_{3}\right)$ concentrations can be used to determine the type of inhibition, whether it is reversible, and values of the inhibition coefficient. Model simulations could be used to evaluate potential alternate treatment methods. Measuring the concentration of $\mathrm{AB} 1$ at the inlet and outlet would provide useful information on dye removal.

2. Additional full-scale data using continuous data acquisition would provide a better basis for a full-scale model validation.

3. A detailed study of the biochemical processes occurring in a red lava rock biofilter used for $\mathrm{H}_{2} \mathrm{~S}$ removal would provide information useful for determining the Biofilter ${ }^{\mathrm{TM}}$ model input parameters. To determine if any abiotic reactions occur, $\mathrm{H}_{2} \mathrm{~S}$ removal using a column of sterilized lava rock (e.g. autoclaved) at low $\mathrm{pH}$ could be ascertained.

4. Biofilter ${ }^{\mathrm{TM}}$ could be upgraded to allow for variable temperature input by subroutines that calculate the temperature-dependant variables (e.g. $\mu_{\max }, D_{b}$, and $H$ ) as a function of temperature. 


\section{APPENDIX A}

\section{BIOFILTER $^{\text {TM }}$ CALIBRATION AND VALIDATION ACCOUNTING FOR VARIABLE FLOW AND DEPTH PROFILE OF HYDROGEN SULFIDE CONCENTRATION}

\section{A.1 INTRODUCTION}

Data from the Cedar Rapids Water Pollution Control Facility pilot-scale and full-scale biofilters was used to calibrate and validate the model presented by Li et al. (2002). The userfriendly software Biofilter ${ }^{\mathrm{TM}}$ (Crittenden et al., 2002) was used to obtain model parameter values. The original solution resulting in the model parameters used in the original calibration and validation presented in Chapter 3 may be only one of several possible solutions. This solution was obtained from initial estimates of the parameters based on literature citations and engineering judgment. However, limiting a solution to these rules may preclude other potential solutions that may provide insight into unexpected chemical-physical processes. Furthermore, the solution obtained in Chapter 3 was based on several simplified assumptions (discussed below). Additional data and information on actual process conditions allows for more representative calibration and validation solutions. Finally, the existence of multiple solutions forces the user to consider the conceptual model rather than simply using the software to crank out numbers without considering the meaning behind those numbers and the limitations to the model. When faced with multiple solutions, engineers must use their knowledge and judgment to decide which solution is best for the given circumstances. 


\section{A.2 METHODOLOGY}

Several modifications have been made to the conditions used to obtain the solution in Chapter 3. This solution was based on a constant airflow of $1.7 \mathrm{~m}^{3} / \mathrm{min}\left(60 \mathrm{ft}^{3} / \mathrm{min}\right)$ for both the calibration and validation solutions even though the actual flow varied over these periods. This simplifying assumption was made because very few flow measurements were made during the calibration and validation periods and the uncertainty and variation of flow was very high (see Appendix B). The variable flow values used in this section for the calibration and validation are shown in Table A.1.

Table A.1: Air Flow Measurements for the Calibration and Validation Periods.

\begin{tabular}{|c|c|c|c|}
\hline \multicolumn{2}{|c|}{ Calibration Values } & \multicolumn{2}{c|}{ Validation Values } \\
\hline $\begin{array}{c}\text { Time } \\
\text { (Days) }\end{array}$ & $\begin{array}{c}\text { Flow } \\
\left(\mathbf{m}^{3} / \mathbf{m i n}\right)\end{array}$ & $\begin{array}{c}\text { Time } \\
\text { (Days) }\end{array}$ & $\begin{array}{c}\text { Flow } \\
\left(\mathbf{m}^{3} / \mathbf{m i n}\right)\end{array}$ \\
\hline 0 & 1.67 & 0 & 1.59 \\
\hline 14.3 & 2.01 & 0.04 & 1.59 \\
\hline 15.4 & 2.27 & 0.25 & 2.01 \\
\hline 15.7 & 2.12 & 0.29 & 2.35 \\
\hline 16.4 & 1.95 & 1.2 & 1.70 \\
\hline 20.2 & 1.84 & 1.3 & 1.64 \\
\hline 20.5 & 1.93 & 1.9 & 1.64 \\
\hline 20.7 & 1.95 & 3.2 & 1.56 \\
\hline 21.1 & 1.95 & 4.0 & 1.47 \\
\hline 21.5 & 1.98 & 5.0 & 1.33 \\
\hline 22.0 & 2.15 & 7.4 & 1.50 \\
\hline & & 9.0 & 1.81 \\
\hline & & 11.3 & 1.42 \\
\hline
\end{tabular}

Also, the period used to determine the calibration solutions in this appendix was changed to include more data points. The calibration period was increased from 6.3 days $(12: 30 \mathrm{a} . \mathrm{m}$. on 
March 8, 2000 and ending at 7:30 a.m. on March 14, 2000) in the Chapter 3 solution to 6.7 days (11:30 p.m. on March 7, 2000 and ending at 6:30 p.m. on March 14, 2000) for the solutions determined in this section. While the calibration period only lasted for between 6.3 days and 6.7 days, the actual model simulation covered several weeks of operation because the actual pilotscale biofilter was in operation before the data was collected for the calibration and validation periods. $\mathrm{Li}$ (2002, pp. 244-258) provides the actual data used for the model input of the influent $\mathrm{H}_{2} \mathrm{~S}$ concentrations and the measured effluent $\mathrm{H}_{2} \mathrm{~S}$ concentrations.

In addition to the calibration period, the density of the lava rock used in the biofilter was corrected from $4.0 \mathrm{~g} / \mathrm{cm}^{3}$ to $1.13 \mathrm{~g} / \mathrm{cm}^{3}$. This density and the bed porosity $(\varepsilon)$ of 0.40 were used to recalculate the mass of the lava rock ( $\mathrm{Li}, 2002, \mathrm{p}$. 209). Using the bed diameter of $0.61 \mathrm{~m}$ and the bed depth of $1.83 \mathrm{~m}$, the bed volume in the pilot scale biofilter was determined to be $0.53 \mathrm{~m}^{3}$. Although mass $(\mathrm{M})$ is generally equal to volume $(\mathrm{V})$ multiplied by density $(\rho)$, the empty space between the packing material must be accounted for in a biofilter bed. This is corrected using $\varepsilon$, defined as the ratio of void volume to total volume. Hence, the mass of the lava rock packing material in the pilot-scale biofilter is determined as follows:

$$
\mathrm{M}=\rho \mathrm{V}(1-\varepsilon)=1,130 \mathrm{~kg} / \mathrm{m}^{3}\left(0.53 \mathrm{~m}^{3}\right)(1-0.4)=362 \mathrm{~kg}
$$

Finally, the time average influent $\mathrm{H}_{2} \mathrm{~S}$ concentration was recalculated to include the total run time input into the model. Although this input parameter had only a negligible effect on the model output for the calibration and validation in this section, it had a small, but noticeable effect on the model simulations run to steady state in Chapter 4. The original values used in Chapter 3 and the corrected values used in this section are listed in Table A.2.

After the parameters in Table A.2 were corrected, additional parameters were adjusted to obtain new calibration and validation solutions. The adjusted parameters are: biofilm diffusivity 
$\left(D_{b}\right)$, sphericity $(\phi)$, yield coefficient $(Y)$, half saturation constant $\left(K_{s}\right)$, maximum specific growth rate $\left(\mu_{\max }\right)$, minimum biofilm concentration $\left(\mathrm{C}_{\mathrm{xmin}}\right)$, maximum biofilm concentration $\left(\mathrm{C}_{\mathrm{xmax}}\right)$, and initial biofilm concentration $\left(\mathrm{C}_{\mathrm{xo}}\right)$. These parameters were examined outside of the range specified in Martin et al. (2002) so as not to preclude any potential solutions not considered in the original solution. As in Chapter 3, the calibration and validation solutions were determined by minimizing the objective function (OF) defined in Equation 3.1. However, the sum of the residuals (Equation 3.2) was not included as a criterion because it can be misleading: a comparable number of large negative and positive residuals can cancel each other out. This can be overcome by using the sum of the absolute value of the residuals as follows:

$$
\sum_{\mathrm{i}=1}^{\mathrm{n}}\left|\left(\mathrm{C}_{\text {data, } \mathrm{i}}-\mathrm{C}_{\text {model }, \mathrm{i}}\right) / \mathrm{C}_{\text {model, }, \mathrm{i}}\right|
$$

Where

$$
\begin{aligned}
& \mathrm{n}=\text { the number of data points, } \\
& \mathrm{C}_{\text {data, }, \mathrm{i}}=\text { measured effluent concentration, and } \\
& \mathrm{C}_{\text {model, } \mathrm{i}}=\text { effluent concentration predicted by the model. }
\end{aligned}
$$

In addition to the sum of the absolute value of the residuals and the $\mathrm{OF}$, the $\mathrm{H}_{2} \mathrm{~S}$ concentration profile throughout the depth of the biofilter between the influent and effluent was used to evaluate the accuracy of the model solution. The $\mathrm{H}_{2} \mathrm{~S}$ concentration was manually measured from the digital readout of a Conspec meter at various biofilter bed depth locations between the influent and effluent made at several different times during the calibration period. The samples were drawn from $9 \mathrm{~mm}$ (3/8 inch) ID stainless steel sampling tubes inserted approximately $25 \mathrm{~cm}$ (10 inches), radially toward the column center, at several bed depth locations between the influent and effluent. The wall of these sampling tubes had $3 \mathrm{~mm}(1 / 8$ 
inch) holes drilled along their length with the holes aligned upward, allowing samples to be drawn from throughout the radial length of the bed. Model simulated values of the $\mathrm{H}_{2} \mathrm{~S}$ concentration were determined throughout the depth of the biofilter between the influent and effluent by using an input of 12 axial elements (the bed depth was divided into 12 elements of equal length). The model simulated values were compared to the manual $\mathrm{H}_{2} \mathrm{~S}$ concentrations measured at the various biofilter depths.

Table A.2: Comparison of Original and Corrected Model Input Values.

\begin{tabular}{|c|c|c|c|c|}
\cline { 2 - 5 } \multicolumn{1}{c|}{} & \multicolumn{2}{c|}{ Calibration Values } & \multicolumn{2}{c|}{ Validation Values } \\
\hline Parameter & $\begin{array}{c}\text { Original } \\
\text { (Chapter 3) }\end{array}$ & $\begin{array}{c}\text { New } \\
\text { (Appendix A) }\end{array}$ & $\begin{array}{c}\text { Original } \\
\text { (Chapter 3) }\end{array}$ & $\begin{array}{c}\text { New } \\
\text { (Appendix A) }\end{array}$ \\
\hline Time Period (days) & 6.3 & 6.7 & 10 & 10 \\
\hline $\begin{array}{c}\text { Influent Flow } \\
\left(\mathbf{m}^{\mathbf{3}} / \mathbf{m i n}\right)\end{array}$ & $\begin{array}{c}1.7 \\
\text { (average) }\end{array}$ & $\begin{array}{c}\text { Variable } \\
\text { (see Table A.1) }\end{array}$ & $\begin{array}{c}1.7 \\
\text { (average) }\end{array}$ & $\begin{array}{c}\text { Variable } \\
\text { (see Table A.1) }\end{array}$ \\
\hline $\begin{array}{c}\text { Average Influent } \mathbf{H}_{\mathbf{2}} \mathbf{S} \\
\text { Concentration (mg/L) }\end{array}$ & 0.139 & 0.216 & 0.139 & 0.216 \\
\hline $\begin{array}{c}\text { Density of Lava Rock } \\
\left(\mathbf{g} / \mathbf{c m}^{\mathbf{3}} \text { ) }\right.\end{array}$ & 4.00 & 1.13 & 4.00 & 1.13 \\
\hline $\begin{array}{c}\text { Mass of Lava Rock } \\
(\mathbf{k g})\end{array}$ & 1,280 & 362 & 1,280 & 362 \\
\hline
\end{tabular}

All of the model simulations were run individually and the resulting model simulated $\mathrm{H}_{2} \mathrm{~S}$ concentrations were manually cut and pasted into a Microsoft ${ }^{\mathrm{TM}}$ Excel Spreadsheet to determine the $\mathrm{OF}$ and sum of the absolute value of the residuals for each simulation. Model simulations were run for both the calibration and validation. Also, the effluent $\mathrm{H}_{2} \mathrm{~S}$ concentration as a function of time and the $\mathrm{H}_{2} \mathrm{~S}$ concentration as a function of bed depth were plotted for both the model simulated values and the measured values to allow for visual comparison. 


\section{A.3 RESULTS AND DISCUSSION}

Initially, each model parameter was individually varied to obtain the minimum OF. To obtain further solutions, combinations of $\phi, \mathrm{Y}, \mathrm{K}_{\mathrm{s}}$, and $\mu_{\max }$ were varied; then, $\mathrm{C}_{\mathrm{xmin}}, \mathrm{C}_{\mathrm{xmax}}$, and $\mathrm{C}_{\mathrm{xo}}$ were varied to fine-tune the solution. The value for $\mathrm{D}_{\mathrm{b}}$ obtained in the first re-calibration solution was retained for future simulations. Several hundred model simulations were run spanning a large range of values of the model parameters (see Table A.3). These model simulations resulted in four potential solutions. In future studies, a genetic algorithm may eliminate the tedious manual trial-and-error method required in this study.

Table A.3: Range of Model Parameters Used in Determining the Re-Calibration and ReValidation Solutions and Original Parameter Values used by Martin et al. (2002).

\begin{tabular}{|c|c|c|c|}
\cline { 3 - 4 } \multicolumn{2}{c|}{} & \multicolumn{2}{c|}{ Original Values (1) } \\
\hline Parameter (units) & Range in this study & Calibration & Validation \\
\hline$\phi$ (unitless) & 0.1 to 0.7 & 0.5 & 0.5 \\
\hline $\mathbf{Y}\left(\mathbf{g}\right.$ cells/g-mole $\left.\mathbf{H}_{\mathbf{2}} \mathbf{S}\right)$ & 0.005 to 25 & 3.8 & 3.8 \\
\hline $\mathbf{K}_{\mathbf{s}}(\mu \mathbf{m o l} / \mathbf{L})$ & 0.02 to 133 & 3.5 & 3.5 \\
\hline$\mu_{\max }(\mathbf{1} / \mathbf{h r})$ & 0.048 to 150 & 0.275 & 0.200 \\
\hline $\mathbf{C}_{\mathbf{x} \mathbf{0}}(\mathbf{g} / \mathbf{L})$ & 0.05 to 120 & 10 & 6 \\
\hline $\mathbf{C}_{\mathbf{x} \min }(\mathbf{m g} / \mathbf{L})$ & 4 to 500 & 10 & 10 \\
\hline $\mathbf{C}_{\mathbf{x m a x}}(\mathbf{g} / \mathbf{L})$ & 66 to 2,000 & 100 & 100 \\
\hline $\mathbf{D}_{\mathbf{b}}\left(\mathbf{c m}^{2} / \mathbf{s}\right)$ & 1.68 to 12 & $4.65 \times 10^{(-6)}$ & $3.60 \times 10^{(-6)}$ \\
\hline
\end{tabular}

(1) from Martin et al. (2002)

Figure A.1 shows the model simulated effluent $\mathrm{H}_{2} \mathrm{~S}$ concentrations as a function of time for the calibration period; the curves show the original solution (Chapter 3 ) for constant flow, the original solution for variable flow, and Solution 1 of the re-calibration. Although the model output for the original calibration (Chapter 3) agrees well with the measured data for constant flow, there is a sharp increase in the effluent $\mathrm{H}_{2} \mathrm{~S}$ concentration (from 2.0 to $7.8 \mathrm{ppb}_{\mathrm{v}}$ ) when 
variable flow is introduced. The effluent $\mathrm{H}_{2} \mathrm{~S}$ concentration is even higher when the corrected model input values from Table A.2 are included (data not shown). Solution 1 provides a comparable fit to the original solution, although the effluent $\mathrm{H}_{2} \mathrm{~S}$ concentration is slightly higher than the original solution during the initial influent spike and slightly lower than the original solution during the more stable final period.

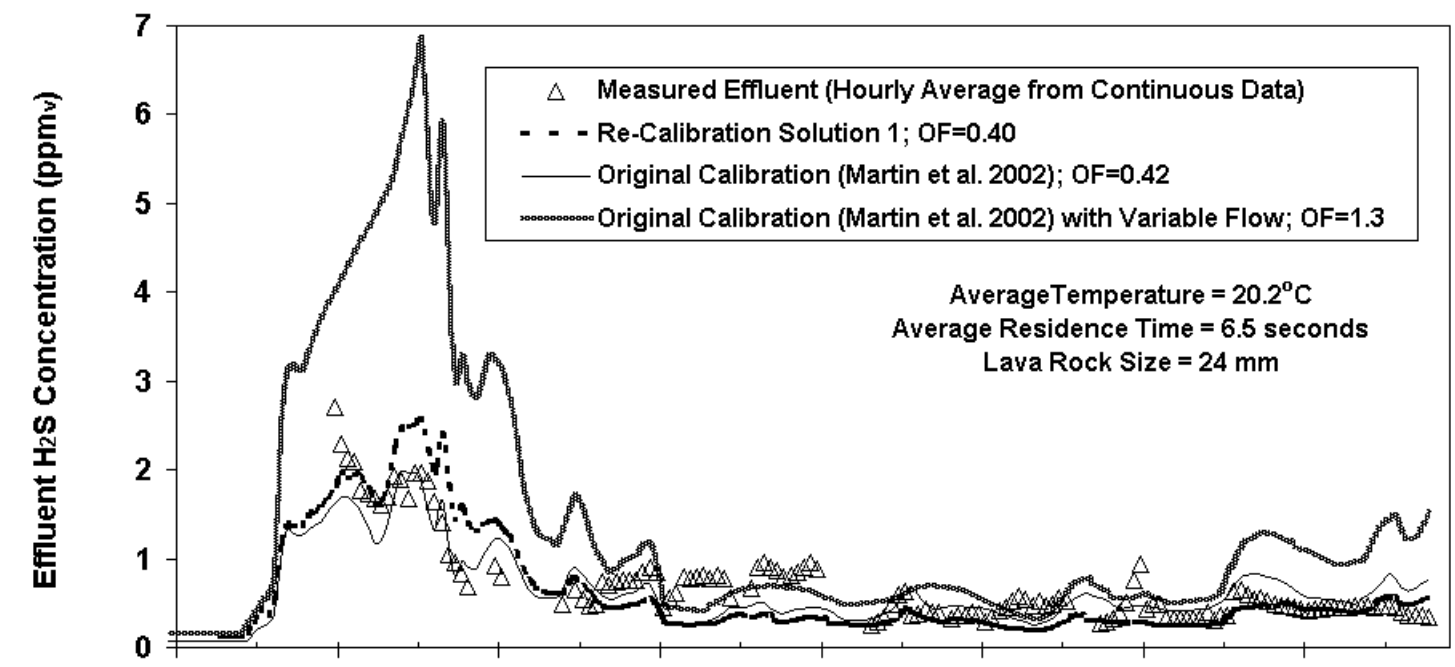

07-Mar-00 08-Mar-00 09-Mar-00 10-Mar-00 11-Mar-00 12-Mar-00 13-Mar-00 14-Mar-00

Date

Figure A.1: Comparison of the Output from Various Model Calibration Conditions to the Measured Data for Pilot Scale Biofilter: Effluent Hydrogen Sulfide Concentration as a Function of Time.

Figure A.2 shows model simulated effluent $\mathrm{H}_{2} \mathrm{~S}$ concentrations as a function of time for the validation period; the curves show the original solution (Chapter 3) for constant flow, the original solution for variable flow and corrected values (Table A.2), and Solution 1 of the revalidation. Solution 1 provides a comparable fit to the original solution, although the effluent $\mathrm{H}_{2} \mathrm{~S}$ concentration is slightly lower than the original solution during the initial start-up period, which is shown at the beginning of the plot. Unlike the calibration period, the model output 
effluent $\mathrm{H}_{2} \mathrm{~S}$ concentration for the validation period does not change significantly when the corrected model input values from Table A.2 are included. This is because input values (in Table A.2) have a much smaller effect on the effluent $\mathrm{H}_{2} \mathrm{~S}$ concentration during initial start-up than after the biofilter has been run for a significantly long time. This was observed in the steady-state model simulations run in Chapter 4 and is explained by the biofilm having sufficient time to develop; initially, there is a concentration of $\mathrm{C}_{\mathrm{xo}}$ biomass distributed evenly through the entire biofilter, but after time, the biomass concentration and distribution through the column change. The influent flow, average influent $\mathrm{H}_{2} \mathrm{~S}$ concentration, and mass of lava rock in the biofilter all have a significant effect on the biofilm development which will not be apparent until after the biofilm has changed from the initial condition.

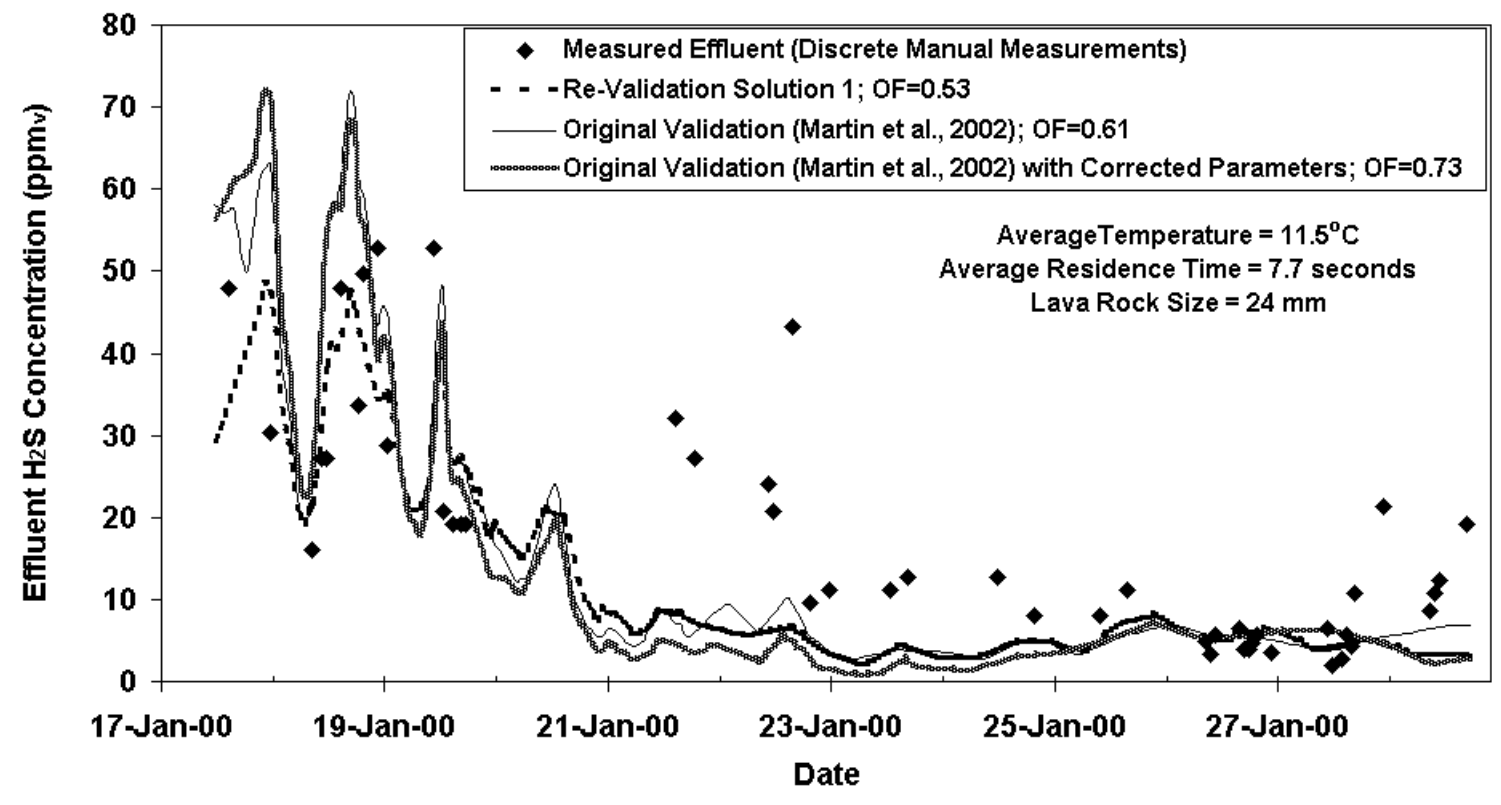

Figure A.2: Comparison of the Output from Various Model Validation Conditions to the Measured Data for Pilot Scale Biofilter: Effluent Hydrogen Sulfide Concentration as a Function of Time. 
Figure A.3 shows the model simulated effluent $\mathrm{H}_{2} \mathrm{~S}$ concentrations for all four recalibration solutions. All four solutions are comparable, although the effluent $\mathrm{H}_{2} \mathrm{~S}$ concentration for Solution 4 is significantly lower than the other three solutions during the more stable final period. Similarly, Figure A.4 shows the model simulated effluent $\mathrm{H}_{2} \mathrm{~S}$ concentration for all four re-validation solutions. All four solutions result are comparable, although the effluent $\mathrm{H}_{2} \mathrm{~S}$ concentration is slightly lower for Solution 3 during the initial start-up period and has slightly higher peaks for Solution 4 after the initial start-up period.

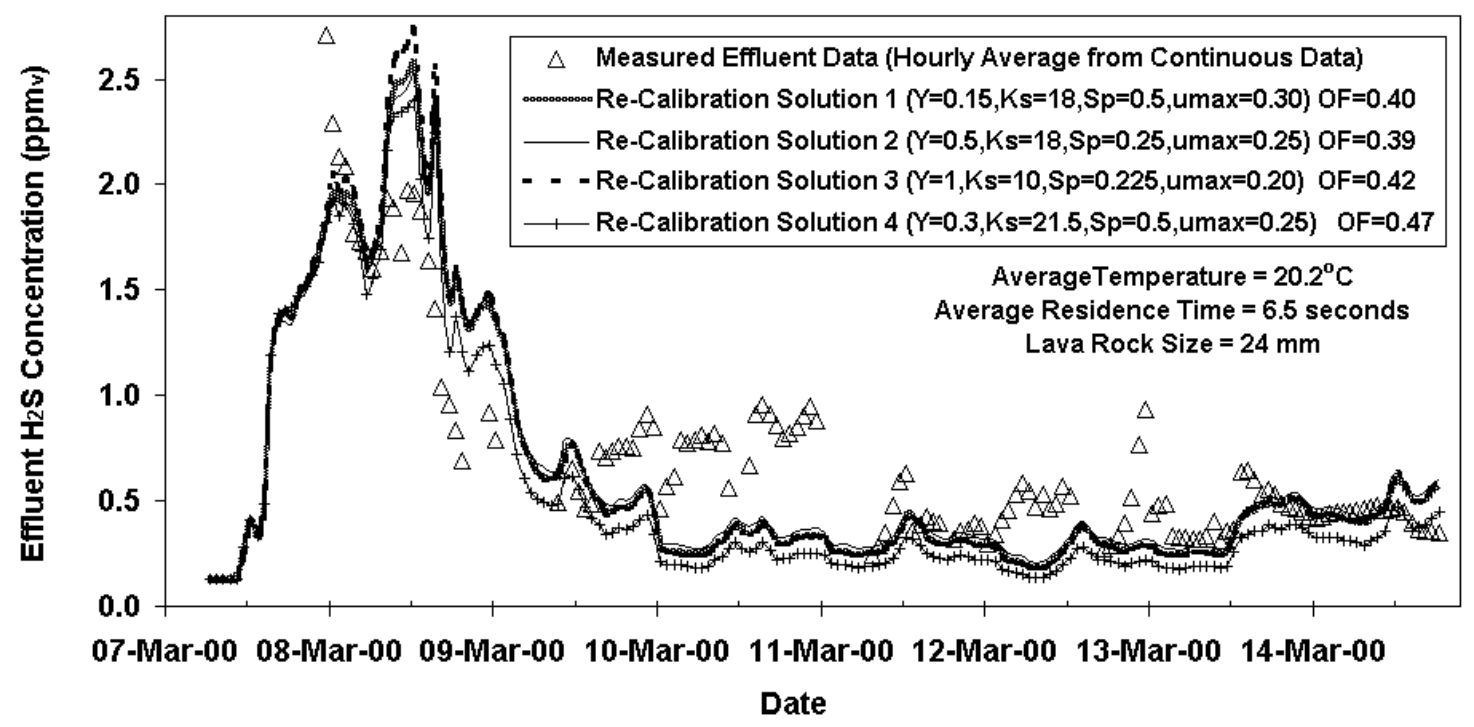

Figure A.3: Comparison of Re-calibration Solutions: Effluent Hydrogen Sulfide Concentration as a Function of Time.

The OF and sum of the absolute value of the residuals for the re-calibration and revalidation and the original solutions are listed in Table A.4. This provides a quantitative evaluation tool to supplement the qualitative evaluations of Figures A.1, A.2, A.3, and A.4. The values of the OF and sum of the absolute value of the residuals for the solutions determined in 
the re-calibration are comparable to those in the original solution using constant flow and uncorrected input values. However, when the variable flow and the other corrected input values (from Table A.2) are used with the original solution, the values of the OF and sum of the absolute value of the residuals are significantly higher for the original calibration solution. This indicates that the fit of the corrected original calibration solution to the data is not as good as the other calibration solutions. The fit of the corrected original validation solution is only slightly worse than the uncorrected original validation solution.

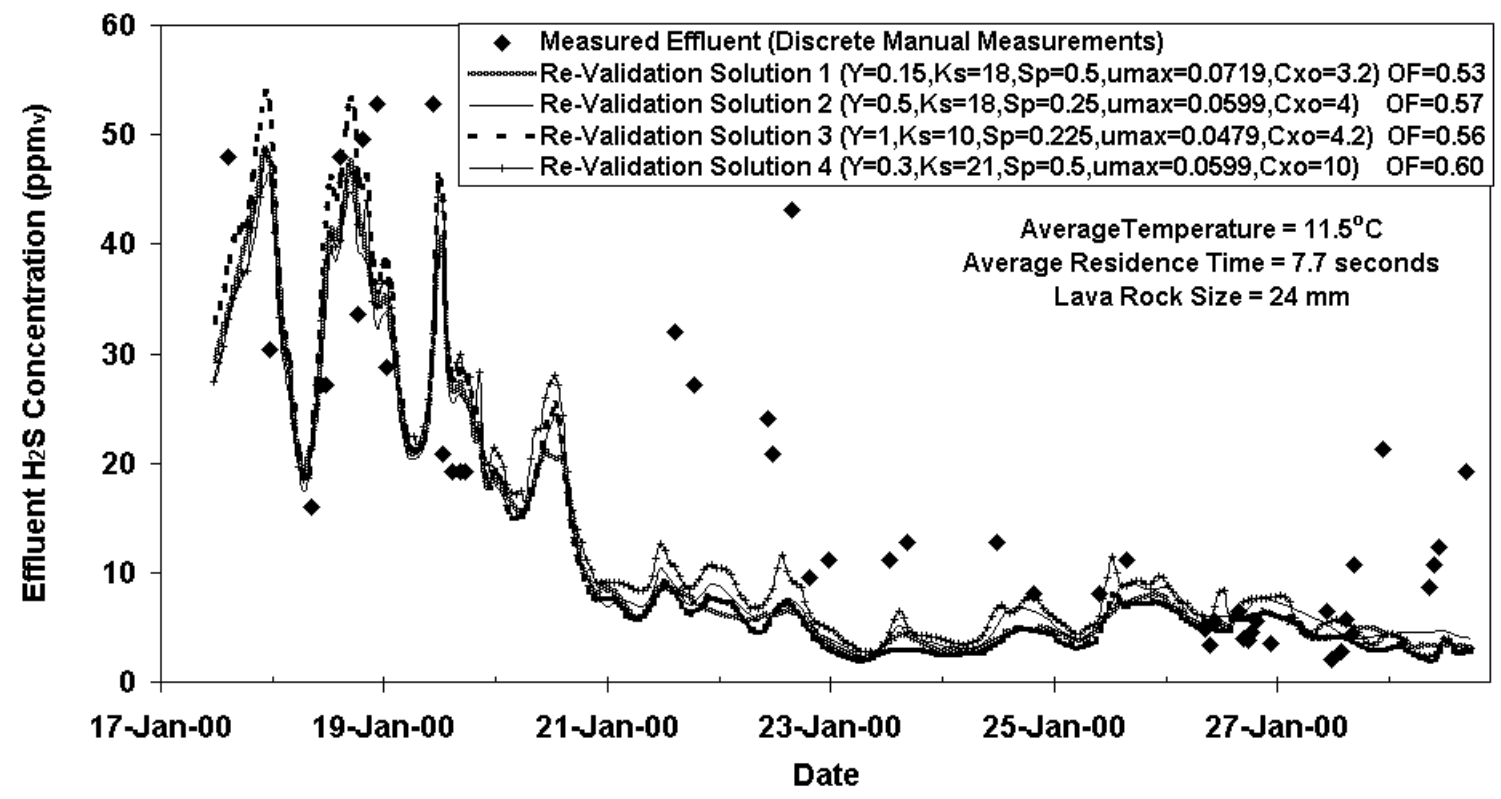

Figure A.4: Comparison of Re-validation Solutions: Effluent Hydrogen Sulfide Concentration as a Function of Time. 
Table A.4: Comparison of Objective Function and Sum of Absolute Value of Residuals for Re-calibration, Re-validation, and Original Solution.

\begin{tabular}{|c|c|c|c|c|}
\cline { 2 - 5 } \multicolumn{1}{c|}{} & \multicolumn{2}{c|}{ Calibration } & \multicolumn{2}{c|}{ Validation } \\
\hline Solution & $\begin{array}{c}\text { Objective } \\
\text { Function }\end{array}$ & $\begin{array}{c}\text { Sum of } \\
\mid \text { Residuals } \mid\end{array}$ & $\begin{array}{c}\text { Objective } \\
\text { Function }\end{array}$ & $\begin{array}{c}\text { Sum of } \\
\mid \text { Residuals } \mid\end{array}$ \\
\hline Solution 1 & 0.40 & 0.33 & 0.53 & 0.46 \\
\hline Solution 2 & 0.39 & 0.32 & 0.57 & 0.48 \\
\hline Solution 3 & 0.42 & 0.34 & 0.56 & 0.49 \\
\hline Solution 4 & 0.47 & 0.41 & 0.62 & 0.51 \\
\hline Original Solution (1) & 0.42 & 0.35 & 0.61 & 0.52 \\
\hline $\begin{array}{c}\text { Original Solution } \\
\text { for corrected values (2) }\end{array}$ & 1.31 & 1.01 & 0.69 & 0.57 \\
\hline
\end{tabular}

(1) Original Solution from Martin et al. (2002) for constant flow; OF re-calculated for new period.

(2) Original Solution from Martin et al. (2002) for variable flow (all corrected model input values from Table A.2 are used in the validation); OF re-calculated for new period.

Figure A.5 shows the $\mathrm{H}_{2} \mathrm{~S}$ concentration profile through the depth of the biofilter bed between the influent and effluent for the actual data and for the model simulations for the four different solutions. The values for the actual data shown in Figure A.5 are averages from seven manual depth concentration measurements made each day from Mach 12, 2000 through Mach 14, 2000. At high $\mathrm{H}_{2} \mathrm{~S}$ concentrations (near the influent) the error bars represent the $95 \%$ confidence limits; at low $\mathrm{H}_{2} \mathrm{~S}$ concentrations (greater than $40 \mathrm{~cm}$ from the influent) the error bars represent the uncertainty of the Conspec meter (see Appendix B). The values for the model simulation outputs shown in Figure A.5 are the averages from model simulation outputs corresponding to the times of the manual depth concentration measurements. Because the influent $\mathrm{H}_{2} \mathrm{~S}$ concentration changed over time, normalized $\mathrm{H}_{2} \mathrm{~S}$ concentrations (obtained by dividing by the $\mathrm{H}_{2} \mathrm{~S}$ concentration by the influent $\mathrm{H}_{2} \mathrm{~S}$ concentration) were used. The original model calibration solution (Chapter 3) predicts a much higher $\mathrm{H}_{2} \mathrm{~S}$ concentration throughout the bed depth between the influent and effluent than shown by the actual data. Solution 1 and 
Solution 2 provide the best fit to the actual data for the first $40 \mathrm{~cm}$ from the influent; Solution 4 provides the best fit to the actual data for the bed depth from $40 \mathrm{~cm}$ to $90 \mathrm{~cm}$ from the influent. Although significantly better than the original solution, the depth profile for Solution 3 is higher than the actual data for the first $100 \mathrm{~cm}$ from the influent.

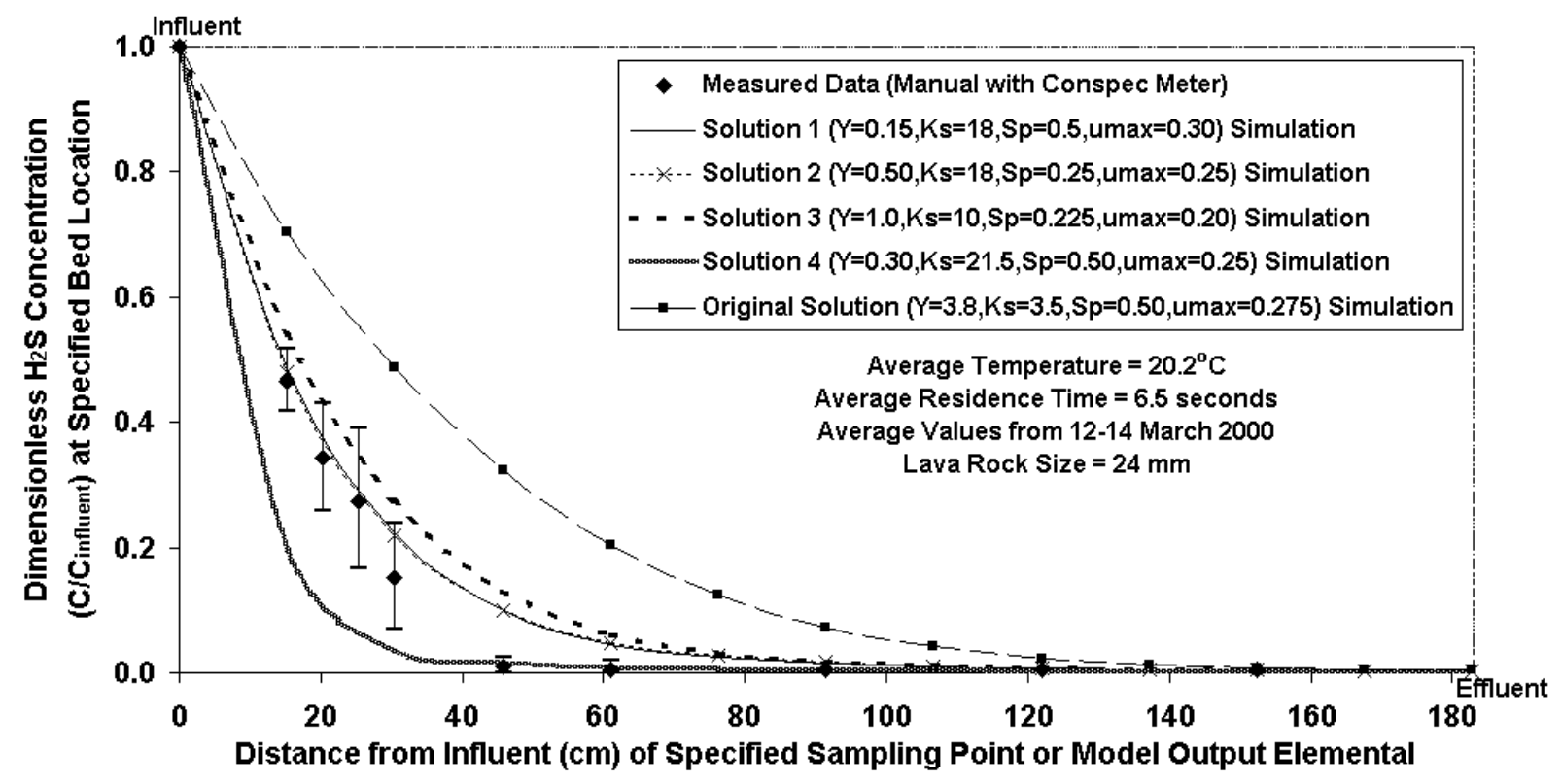

Figure A.5: Comparison of Original and Re-calibration Solutions to Measured Data: for Bed Profile of Hydrogen Sulfide Concentration as a Function of Distance from Influent.

It is important to note that a majority of the $\mathrm{H}_{2} \mathrm{~S}$ is removed in the portion of the biofilter bed nearest to the influent. The model simulations indicate that the highest concentration of active biomass is located in the biofilter nearest to the influent. According to the data, $85 \% \mathrm{H}_{2} \mathrm{~S}$ removal occurs within the first $30 \mathrm{~cm}$ (12 inches) from the influent and over 97\% removal occurs within the first $46 \mathrm{~cm}$ (18 inches) from the influent. The model simulation for Solution 1 predicts that $78 \% \mathrm{H}_{2} \mathrm{~S}$ removal occurs within the first $30 \mathrm{~cm}$ (12 inches) from the influent and 90\% removal occurs within the first $46 \mathrm{~cm}$ (18 inches) from the influent. 
Examination of the Monod equation provides insight into the reaction rate at low and high substrate concentrations. According to the Monod equation, the specific growth rate, $\mu$ (1/time), can be expressed as follows:

$$
\mu=\mu_{\max }\left[\mathrm{H}_{2} \mathrm{~S}\right] /\left(\mathrm{K}_{\mathrm{s}}+\left[\mathrm{H}_{2} \mathrm{~S}\right]\right)
$$

Where

$$
\begin{aligned}
& \mu_{\max }=\text { maximum specific growth rate }(1 / \text { time }) \\
& \mathrm{K}_{\mathrm{s}}=\text { half-saturation constant (moles/volume) } \\
& {\left[\mathrm{H}_{2} \mathrm{~S}\right]=\text { hydrogen sulfide concentration in the biofilm (moles/volume) }}
\end{aligned}
$$

At low substrate concentrations, where $\mathrm{K}_{\mathrm{s}}>>\left[\mathrm{H}_{2} \mathrm{~S}\right]$, the Monod equation reduces to first-order kinetics:

$$
\mu=\mu_{\max }\left[\mathrm{H}_{2} \mathrm{~S}\right] / \mathrm{K}_{\mathrm{s}}
$$

At high substrate concentrations, where $\mathrm{K}_{\mathrm{s}}<<\left[\mathrm{H}_{2} \mathrm{~S}\right]$, the Monod equation reduces to zero-order kinetics:

$$
\mu=\mu_{\max }
$$

Figure A.5 shows that near the effluent, the $\mathrm{H}_{2} \mathrm{~S}$ concentration is very low. For the original solution (from Chapter 3), the model simulated depth-average $\mathrm{H}_{2} \mathrm{~S}$ concentration in the biofilm at the effluent is $0.0017 \mu \mathrm{mol} / \mathrm{L}$, compared to a $\mathrm{K}_{\mathrm{s}}$ of $3.5 \mu \mathrm{mol} / \mathrm{L}$; for Solution 1 , the model simulated depth-average $\mathrm{H}_{2} \mathrm{~S}$ concentration in the biofilm at the effluent is 0.0009 $\mu \mathrm{mol} / \mathrm{L}$, compared to a $\mathrm{K}_{\mathrm{s}}$ of $18 \mu \mathrm{mol} / \mathrm{L}$. For all solutions (the four re-calibration solutions in this Appendix and the original solution from Chapter 3), the depth-average $\mathrm{H}_{2} \mathrm{~S}$ concentration in the biofilm near the effluent is much lower than $\mathrm{K}_{\mathrm{s}}$ and the reaction kinetics are first-order according to Equation A.4. Using the 250- $\mathrm{ppm}_{\mathrm{v}}$ peak influent $\mathrm{H}_{2} \mathrm{~S}$ concentration in the gasphase (from Figure 3.2 in Chapter 3), the maximum $\mathrm{H}_{2} \mathrm{~S}$ concentration in the biofilm at the 
influent is $27 \mu \mathrm{mol} / \mathrm{L}$, which is the same order of magnitude as $\mathrm{K}_{\mathrm{s}}$ for all solutions. Therefore, throughout the biofilter bed, the reaction rate is always greater than zero order and approaches first order as the location in the biofilter approaches the effluent.

Table A.5 lists the new values of the model parameters for each solution determined in the re-calibration. Table A.6 lists the model parameters for each solution determined in the revalidation (model parameter which were unchanged from the re-calibration to re-validation are listed in Table A.5).

Table A.5: Model Parameters from Re-calibration Solutions.

\begin{tabular}{|c|c|c|c|c|}
\cline { 2 - 5 } & \multicolumn{4}{c|}{ Re-calibration Parameter Values } \\
\hline Parameter (units) & Solution 1 & Solution 2 & Solution 3 & Solution 4 \\
\hline$\phi($ unitless) & 0.50 & 0.25 & 0.225 & 0.50 \\
\hline $\mathbf{Y}\left(\mathbf{g}\right.$ cells/g-mole $\left.\mathbf{H}_{\mathbf{2}} \mathbf{S}\right)$ & 0.15 & 0.50 & 1.00 & 0.30 \\
\hline $\mathbf{K}_{\mathbf{s}}(\boldsymbol{\mu m o l} / \mathbf{L})$ & 18.0 & 18.0 & 10.0 & 21.5 \\
\hline$\mu_{\max }(\mathbf{1} / \mathbf{h r})$ & 0.30 & 0.25 & 0.20 & 0.25 \\
\hline $\mathbf{C}_{\mathbf{x} \mathbf{0}}(\mathbf{g} / \mathbf{L})$ & 10 & 12 & 13 & 10 \\
\hline $\mathbf{C}_{\mathbf{x m i n}}(\mathbf{m g} / \mathbf{L})$ & 10 & 10 & 10 & 100 \\
\hline $\mathbf{C}_{\mathbf{x m a x}}(\mathbf{g} / \mathbf{L})$ & 100 & 100 & 100 & 1,000 \\
\hline $\mathbf{D}_{\mathbf{b}}\left(\mathbf{c m}^{\mathbf{2}} / \mathbf{s}\right)$ & $2.18 \times 10^{(-6)}$ & $2.18 \times 10^{(-6)}$ & $2.18 \times 10^{(-6)}$ & $2.18 \times 10^{(-6)}$ \\
\hline
\end{tabular}

Comparison of the model parameters from the original solution (Table A.3) to those for the re-calibration and re-validation solutions shows that many parameters were changed, some by an order of magnitude. Some values did not change: $\phi$ (for Solution 1 and Solution 4), $\mathrm{C}_{\mathrm{xo}}$ (for Solution 1 and Solution 4, re-calibration), and $\mathrm{C}_{\mathrm{xmax}}$ and $\mathrm{C}_{\mathrm{xmin}}$ (for Solution 1, Solution 2, and Solution 3 ). The values of $\mu_{\max }$ in the re-calibration and re-validation solutions were only slightly smaller or larger than the value in the original solution. Also, $\mathrm{D}_{\mathrm{b}}$ was lower in the recalibration and re-validation solutions, possibly due to the uncertainty in the biofilm thickness, 
which was used to estimate $D_{b}$ (Fan et al., 1990). The lower value of $D_{b}$ indicates that the $H_{2} S$ diffuses through biofilm more slowly.

Table A.6: Model Parameters from Re-validation Solutions.

\begin{tabular}{|c|c|c|c|c|}
\cline { 2 - 5 } \multicolumn{1}{c|}{} & \multicolumn{4}{c|}{ Re-validation Parameter Values } \\
\hline Parameter (units) & Solution 1 & Solution 2 & Solution 3 & Solution 4 \\
\hline$\mu_{\max }(\mathbf{1} / \mathbf{h r})$ & 0.072 & 0.060 & 0.048 & 0.060 \\
\hline $\mathbf{C}_{\mathbf{x} \mathbf{0}}(\mathbf{g} / \mathbf{L})$ & 3.2 & 4.0 & 4.2 & 10 \\
\hline $\mathbf{D}_{\mathbf{b}}\left(\mathbf{c m}^{2} / \mathbf{s}\right)$ & $1.68 \times 10^{(-6)}$ & $1.68 \times 10^{(-6)}$ & $1.68 \times 10^{(-6)}$ & $1.68 \times 10^{(-6)}$ \\
\hline
\end{tabular}

The values for $\phi$ in Solution 2 and Solution 3 are lower than from the original solution determined in Chapter 3. The depth concentration profile for the model output better fit the measured data when $\phi$ was decreased. For a non-spherical object, $\phi$ is defined as the ratio of the surface area of an equivalent volume sphere to the actual surface area of the object; $\phi=1$ for a spherical object. For the porous lava rock, the surface area of the pores should be considered if the pores are not filled with water. While Li (2002, pp.203-208) concluded that the pores were filled with water, this was based on a laboratory analysis that did not consider the larger pores $(>0.6 \mathrm{~mm})$ and a calculation of capillary rise that does not consider the non-homogeneity and interconnectedness of the pores present in lava rock (Saar, 1998). Thus, if there is biofilm growth on the surface of the pores, $\phi$ will decrease. Also, since $\phi$ is used for determining the specific active biofilm area by Biofilter ${ }^{\mathrm{TM}}$, a heterogeneous biofilm geometry would decrease $\phi$ (if the biofilm were not covered with water). Gjaltema et al. (1994) point out that biofilm nonhomogeneity can increase the surface area of the biofilm available for mass transfer more than an order of magnitude. 
In Solution $4, \mathrm{C}_{\mathrm{xmin}}$ and $\mathrm{C}_{\mathrm{xmax}}$ are ten times higher than from the original solution determined in Chapter 3. These high concentrations of active biomass in the biofilm seem unlikely since observations of the lava rock taken from the biofilter showed no visible sign of a biofilm and microbial analysis indicated a low number of microorganisms (Li, 2002, pp. 214230). Also, small changes in $\mathrm{C}_{\mathrm{xo}}$ did not significantly change the effluent $\mathrm{H}_{2} \mathrm{~S}$ concentration for the calibration period; $\mathrm{C}_{\mathrm{xo}}$ was varied to fine-tune the validation in order to obtain a lower $\mathrm{OF}$. The value of $\mathrm{C}_{\mathrm{xo}}$ was higher in the calibration than in validation (except for Solution 4, for which they were equal). This can be explained by a higher concentration of active biomass in the biofilm at initial start-up during the calibration period than at initial start-up during the validation. The calibration period came after the validation and the biofilter was shut down in between; thus, active biomass (at a higher initial active biomass concentration) may have lain dormant within the biofilter bed between the validation and calibration periods.

The most significant changes in the values for the model parameters were for $\mathrm{Y}$ and $\mathrm{K}_{\mathrm{s}}$. $\mathrm{K}_{\mathrm{s}}$ was increased by three to six times and $\mathrm{Y}$ was decreased to between $4 \%$ and $25 \%$ of the values from the original solution (from Chapter 3). The depth concentration profile for the model better fit the measured data by simultaneously increasing $\mathrm{K}_{\mathrm{s}}$ and decreasing $\mathrm{Y}$. A decrease in $\mathrm{Y}$ represents a decrease in biomass formation per unit of substrate $\left(\mathrm{H}_{2} \mathrm{~S}\right)$ consumed. A higher $\mathrm{K}_{\mathrm{s}}$ represents a higher substrate concentration necessary for the specific growth rate to approach the maximum specific growth rate for that substrate. In wastewater treatment, a higher $\mathrm{K}_{\mathrm{s}}$ represents a less easily biodegradable compound.

One possible explanation for the lower $\mathrm{Y}$ and higher $\mathrm{K}_{\mathrm{s}}$ is another microorganism in the biofilter bed. In fact, the original parameter estimation was based on Acidithiobacillus thiooxidans, not $A$. ferrooxidans because little information on the biokinetic parameters for $A$. 
ferrooxidans was available (Martin, et al., 2002). Li (2002, pp. 214-230) suggested that the $\mathrm{H}_{2} \mathrm{~S}$ might actually be reacting with the iron released from the lava rock at low $\mathrm{pH}$. If some of the substrate $\left(\mathrm{H}_{2} \mathrm{~S}\right)$ is reacting with the iron, it does not directly result in biomass formation, thus lowering the apparent yield. It would also mean that a higher concentration would be required to approach the maximum specific growth rate, $\mathrm{K}_{\mathrm{s}}$.

It may even be possible that the model input parameters are different in different parts of the biofilter. Since the $\mathrm{pH}$ and $\mathrm{H}_{2} \mathrm{~S}$ concentration change with the depth of the bed, it is likely that some of the model parameters will change with $\mathrm{pH}$ so it is likely that various model parameters will also change with the depth of the bed. In fact, completely different microcosms may exist at the bottom and top of the column. For example, another sulfide-utilizing microorganism (e.g. A. thiooxidans) may be present at the top of the biofilter bed. The lava rock sample used in the microbial analysis indicating A. ferrooxidans was taken from the bottom of the biofilter bed.

Ultimately, one solution must be chosen when using Biofilter ${ }^{\mathrm{TM}}$ in a design and optimization application. Although the range of solutions can be used to illustrate the range of uncertainty in the model simulated output (see Appendix B), the engineer must choose the best solution. Solution 1 was chosen as the best solution for the model parameter input values used in Chapter 4. Solution 1 had the lowest total sum of the OF and sum of absolute value of residuals, although Solution 2 and Solution 3 had only slightly higher values. Solution 4 was eliminated because the model simulated output included negative biomass concentrations at the biofilm surface in the top of biofilter bed for high loading conditions (data not shown). Also, Solution 3 did not fit the depth profile as well as Solution 1 and Solution 2. Finally, although Solution 2 
provided results similar to Solution 1, it was excluded because $\phi$ would most likely be closer to 0.50 (Solution 1) than to 0.25 (Solution 2).

\section{A.4 CONCLUSIONS}

1. More than one numerical solution to the model may be possible, and examination of these solutions may provide insight into poorly understood processes.

2. By comparing the model output to the actual data and observations, some solutions may be eliminated while others may be considered likely.

3. While multiple numerical solutions to the model may be obtained, the best solution must be chosen for future use of model applications.

4. The parameters in Solution 1 were chosen for the design and optimization applications in Chapter 4.

\section{A.5 REFERENCES}

Biofilter $^{\mathrm{TM}}$ : Biofilter Model Software, Authors: J.C. Crittenden, H. Hautakangas, H. Li, J.R. Mihelcic, E. Oman, Michigan Technological University, National Center for Clean Industrial and Treatment Technologies Environmental Technologies Design Option Tool, Version 1.1, released, April, 2002.

Fan, L.-S.; Leyva-Ramos, R.; Wisecarver, K.D.; and Zehner, B.J. (1990) Diffusion of Phenol Through a Biofilm Grown on Activated Carbon Particles in a Draft-Tube Three-Phase FluidizedBed Bioreactor. Biotechnol. Bioeng., 35, 279. 
Gjaltema, A., Arts, P.A.M., van Loosdrencht, M.C.M., Kuenen, J.G., and Heijnen, J.J. (1994)

"Heterogeneity of Biofilms in Rotating Annular Reactors: Occurrence, Structure, and Consequences", Biotechnol. Bioeng., 44, 194.

Li, H. (2002) Modeling and Optimization of Biofiltration for Odor Control, PhD dissertation, Michigan Technological University, Houghton.

Li, H., J.R. Mihelcic, J.C. Crittenden, K.A. Anderson (2002) Field Measurements and Modeling of a Two-Stage Biofilter that Treats Odorous Sulfur Emissions. Journal of Environmental Engineering, in press.

Martin, RW, H Li., JR Mihelcic, JC Crittenden, DR Lueking, CR Hatch, P Ball (2002)

Optimization of biofiltration for odor control: Model Verification and Applications. Water Environment Research. 72(1): 17-27.

Saar, M.O. (1998) The Relationship Between Permeability, Porosity, and Microstructure in Vesicular Basal, MS thesis, University of Oregon, Eugene. 


\section{APPENDIX B \\ UNCERTAINTY IN MODEL SIMULATED EFFLUENT HYDROGEN SULFIDE CONCENTRATION}

Because of the uncertainty in many of the model input parameters, there is a large uncertainty in the model simulated effluent $\mathrm{H}_{2} \mathrm{~S}$ concentration. It is difficult to quantify this uncertainty in the model simulated effluent $\mathrm{H}_{2} \mathrm{~S}$ concentration. However, the uncertainty of a single parameter can be used to approximate the uncertainty in the model simulated effluent $\mathrm{H}_{2} \mathrm{~S}$ concentration for that specific parameter. The parameter uncertainty can be expressed as the $95 \%$ confidence limit ( \pm 2 standard deviations) and both the high and low limits are separately plugged into the model producing two separate simulated effluent $\mathrm{H}_{2} \mathrm{~S}$ concentrations which represent the $95 \%$ confidence limit for that parameter. Plots of the effluent $\mathrm{H}_{2} \mathrm{~S}$ concentration as a function of time showing both the high and low $95 \%$ confidence limits for a specific model input parameter provides a more easily understood visual representation of the uncertainty in the model simulated effluent $\mathrm{H}_{2} \mathrm{~S}$ concentration.

For the calibration and validation in Chapter 4 and Appendix A, the greatest uncertainty of the measured values is for the temperature and flow measurements. The biofilter temperatures measured at various bed locations and for the feed air varied from $16^{\circ} \mathrm{C}$ to $27^{\circ} \mathrm{C}\left(61^{\circ} \mathrm{F}\right.$ to $\left.81^{\circ} \mathrm{F}\right)$ over the course of the calibration period and from $3^{\circ} \mathrm{C}$ to $18^{\circ} \mathrm{C}\left(37^{\circ} \mathrm{F}\right.$ to $\left.65^{\circ} \mathrm{F}\right)$ over the course of the validation period of the pilot-scale biofilter. At any time, the bed temperature varied throughout the bed depths and in the radial direction from the center. During very cold periods, the edges of the pilot biofilter bed were significantly colder than the bed center. Figure B.1 shows a plot of several temperature measurements at various biofilter locations made during the 
calibration period. Although the bed temperature varied widely, an average bed temperature of $20.2^{\circ} \mathrm{C}\left(68.4^{\circ} \mathrm{F}\right)$ was used for the entire calibration period because the model software currently only allows for a single constant input of temperature-dependent variables. The temperature varied even more during the validation period and even fewer temperature measurements were made. An average bed temperature of $11.5^{\circ} \mathrm{C}\left(52.7^{\circ} \mathrm{F}\right)$ was used for the validation period.

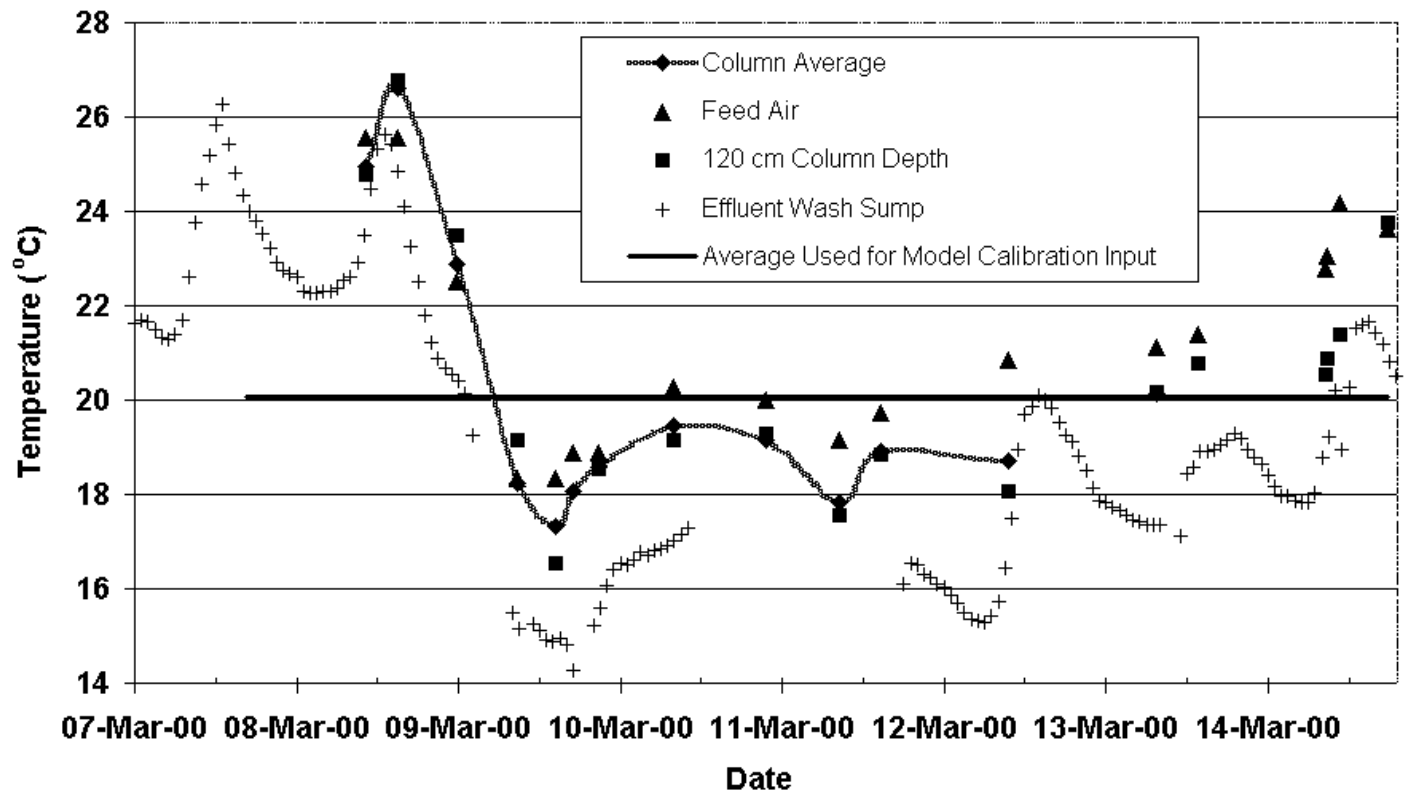

Figure B.1 Biofilter Temperature as a Function of Time at Various Biofilter Bed Locations During Calibration Period.

Figure B.2 shows the model simulated effluent $\mathrm{H}_{2} \mathrm{~S}$ concentration for the Solution 1 recalibration bounded by the uncertainty estimate due to temperature. The upper $95 \%$ confidence limit of temperature was $24.0^{\circ} \mathrm{C}\left(75.2^{\circ} \mathrm{F}\right)$ and the lower limit was $16.4^{\circ} \mathrm{C}\left(61.5^{\circ} \mathrm{F}\right)$. Compared to Solution 1, the model-simulated effluent $\mathrm{H}_{2} \mathrm{~S}$ concentration is much lower using the upper $95 \%$ confidence limit of temperature and much higher using the lower $95 \%$ confidence limit of temperature. During the influent $\mathrm{H}_{2} \mathrm{~S}$ concentration spike at the beginning of the calibration period, the maximum effluent $\mathrm{H}_{2} \mathrm{~S}$ concentration is $2.6 \mathrm{ppm}_{\mathrm{v}}$ at $20.2^{\circ} \mathrm{C}$ compared to $0.8 \mathrm{ppm}_{\mathrm{v}}$ 
and $7.3 \mathrm{ppm}_{\mathrm{v}}$ using the upper $\left(24.0^{\circ} \mathrm{C}\right)$ and lower $\left(16.4^{\circ} \mathrm{C}\right) 95 \%$ confidence limits of temperature, respectively.

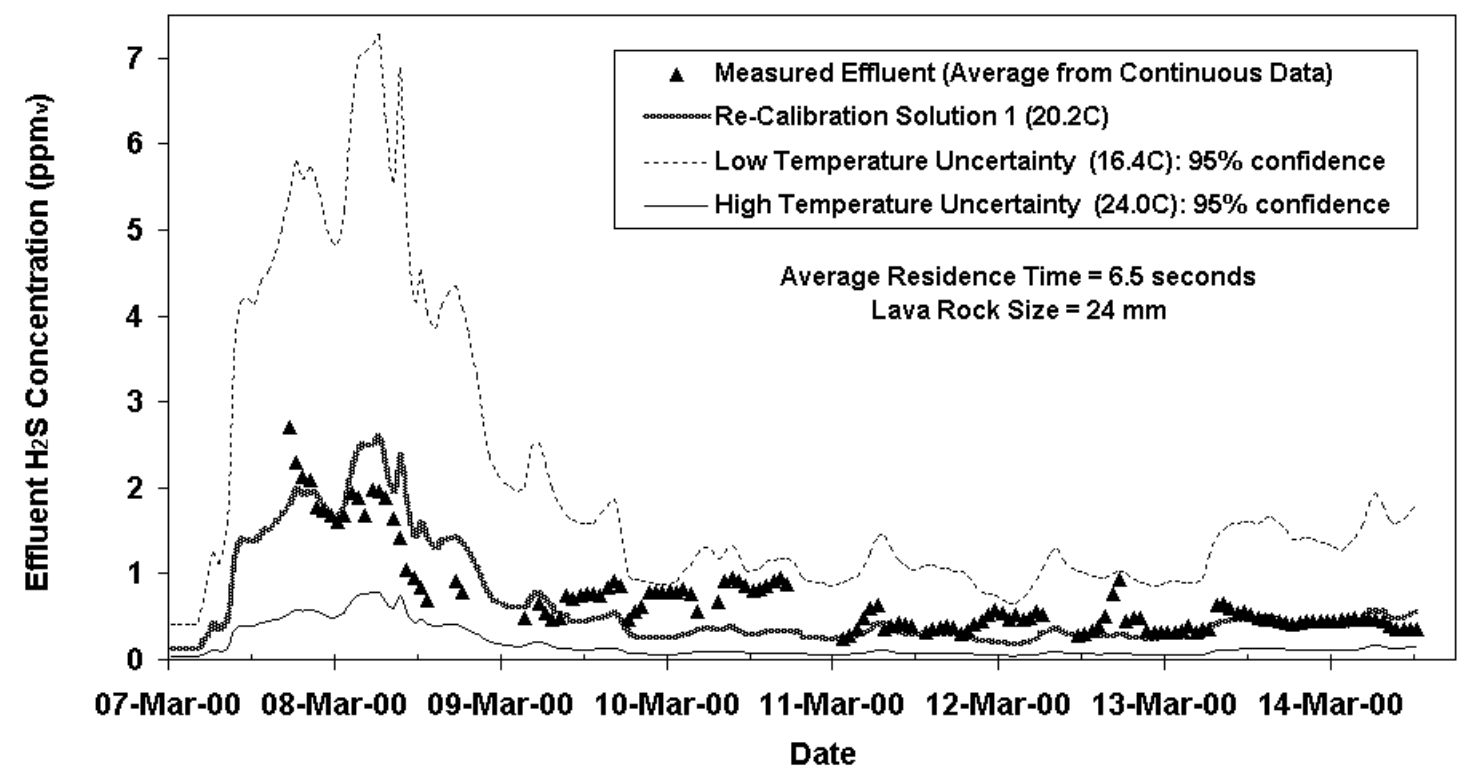

Figure B.2 Model Simulated Effluent $\mathrm{H}_{2} \mathrm{~S}$ Concentration for Solution 1 Re-calibration Showing Temperature Uncertainty Approximation.

During the more stable influent $\mathrm{H}_{2} \mathrm{~S}$ concentration at the end of the calibration period, the minimum effluent $\mathrm{H}_{2} \mathrm{~S}$ concentration is $0.2 \mathrm{ppm}_{\mathrm{v}}$ at $20.2^{\circ} \mathrm{C}$ compared to $0.05 \mathrm{ppm}_{\mathrm{v}}$ and $0.7 \mathrm{ppm}_{\mathrm{v}}$ using the upper $\left(24.0^{\circ} \mathrm{C}\right)$ and lower $\left(16.4^{\circ} \mathrm{C}\right) 95 \%$ confidence limits of temperature, respectively. Plots of the Solution 2, Solution 3, and Solution 4 (determined in Appendix A) re-calibration temperature uncertainties are similar those in Figure B.2 although the maximum effluent $\mathrm{H}_{2} \mathrm{~S}$ concentration spike at the beginning of the calibration period is only $5.4 \mathrm{ppm}_{\mathrm{v}}$ at the lower $\left(16.4^{\circ} \mathrm{C}\right) 95 \%$ confidence limit of temperature (data not shown). It must be pointed out that these are only estimates; it is not strictly accurate to use only a single temperature input if the temperature actually varies with time and location as is the case shown in Figure B.1. 
Figure B.3 shows the model simulated effluent $\mathrm{H}_{2} \mathrm{~S}$ concentration for the Solution 1 revalidation with the approximated uncertainty due to temperature. The upper $95 \%$ confidence limit of temperature was $18.2^{\circ} \mathrm{C}\left(64.8^{\circ} \mathrm{F}\right)$ and the lower limit was $4.8^{\circ} \mathrm{C}\left(40.6^{\circ} \mathrm{F}\right)$. Compared to Solution 1, the model-simulated effluent $\mathrm{H}_{2} \mathrm{~S}$ concentration is much lower using the upper $95 \%$ confidence limit of temperature and much higher using the lower $95 \%$ confidence limit of temperature. During the initial start-up period, the maximum effluent $\mathrm{H}_{2} \mathrm{~S}$ concentration is 49 $\mathrm{ppm}_{\mathrm{v}}$ at $11.5^{\circ} \mathrm{C}$ compared to $22 \mathrm{ppm}_{\mathrm{v}}$ and $95 \mathrm{ppm}_{\mathrm{v}}$ using the upper $\left(18.2^{\circ} \mathrm{C}\right)$ and lower $\left(4.8^{\circ} \mathrm{C}\right)$ 95\% confidence limits of temperature, respectively. Figure B.3 also shows that at higher temperatures, the effluent $\mathrm{H}_{2} \mathrm{~S}$ concentration peak is more effectively suppressed. The maximum effluent $\mathrm{H}_{2} \mathrm{~S}$ concentration peak occurs on January 17,2000 using $18.2^{\circ} \mathrm{C}$ compared to January 19,2000 using $4.8^{\circ} \mathrm{C}$. At the end of the validation period (approximately a week after start-up), the minimum effluent $\mathrm{H}_{2} \mathrm{~S}$ concentration is $2 \mathrm{ppm}_{\mathrm{v}}$ at $11.5^{\circ} \mathrm{C}$ compared to $0.1 \mathrm{ppm}_{\mathrm{v}}$ and $13 \mathrm{ppm}_{\mathrm{V}}$ using the upper $\left(18.2^{\circ} \mathrm{C}\right)$ and lower $\left(4.8^{\circ} \mathrm{C}\right) 95 \%$ confidence limits of temperature, respectively. Plots of Solution 2, Solution 3, and Solution 4 (determined in Appendix A) re-validation using the temperature uncertainty are similar to Figure B.2; however, the maximum effluent $\mathrm{H}_{2} \mathrm{~S}$ concentration peak at the beginning of the validation period ranges from $92 \mathrm{ppm}_{\mathrm{v}}$ to $120 \mathrm{ppm}_{\mathrm{v}}$ using the lower $\left(4.8^{\circ} \mathrm{C}\right) 95 \%$ confidence limit of temperature for Solution 3 and Solution 4 , respectively (data not shown).

There is also uncertainty in the airflow, which was determined from the feed air velocity measured with three different hand-held digital anemometers. Two were hot wire anemometers (Dwyer Series 471 and Extech) and one was a mechanical vane type anemometers (Pacer DA40V). The measurement was made at the center of the feed pipe over the course of the calibration and validation periods. The velocity measurement varied significantly with time, 
even over a one-minute time period; at any time, the velocity measurement varied with location in the cross-section of the feed pipe. Figure B.4 shows a plot of several minimum and maximum feed velocity measurements made during the calibration period. Although the velocity varied widely during a short time-period, average velocities (averaged over a 0.5-hour to 4-hour time period) were used as input for the model re-calibration simulations. Also no velocity measurements were made from 11 a.m. on March 9, 2000 until 11 p.m. on March 13, 2000 because no working anemometer was available. The feed velocity varied similarly during the validation period and even fewer velocity measurements were made. The average flows used for the re-calibration and re-validation are listed in Table A-1, but the actual instantaneous flows varied from $1.3 \mathrm{~m}^{3} / \min$ to $2.6 \mathrm{~m}^{3} / \min \left(46 \mathrm{ft}^{3} / \mathrm{min}\right.$ to $\left.92 \mathrm{ft}^{3} / \min \right)$ for the calibration period and from $0.94 \mathrm{~m}^{3} / \min$ to $2.5 \mathrm{~m}^{3} / \min \left(33 \mathrm{ft}^{3} / \min\right.$ to $\left.88 \mathrm{ft}^{3} / \mathrm{min}\right)$ for the validation period.

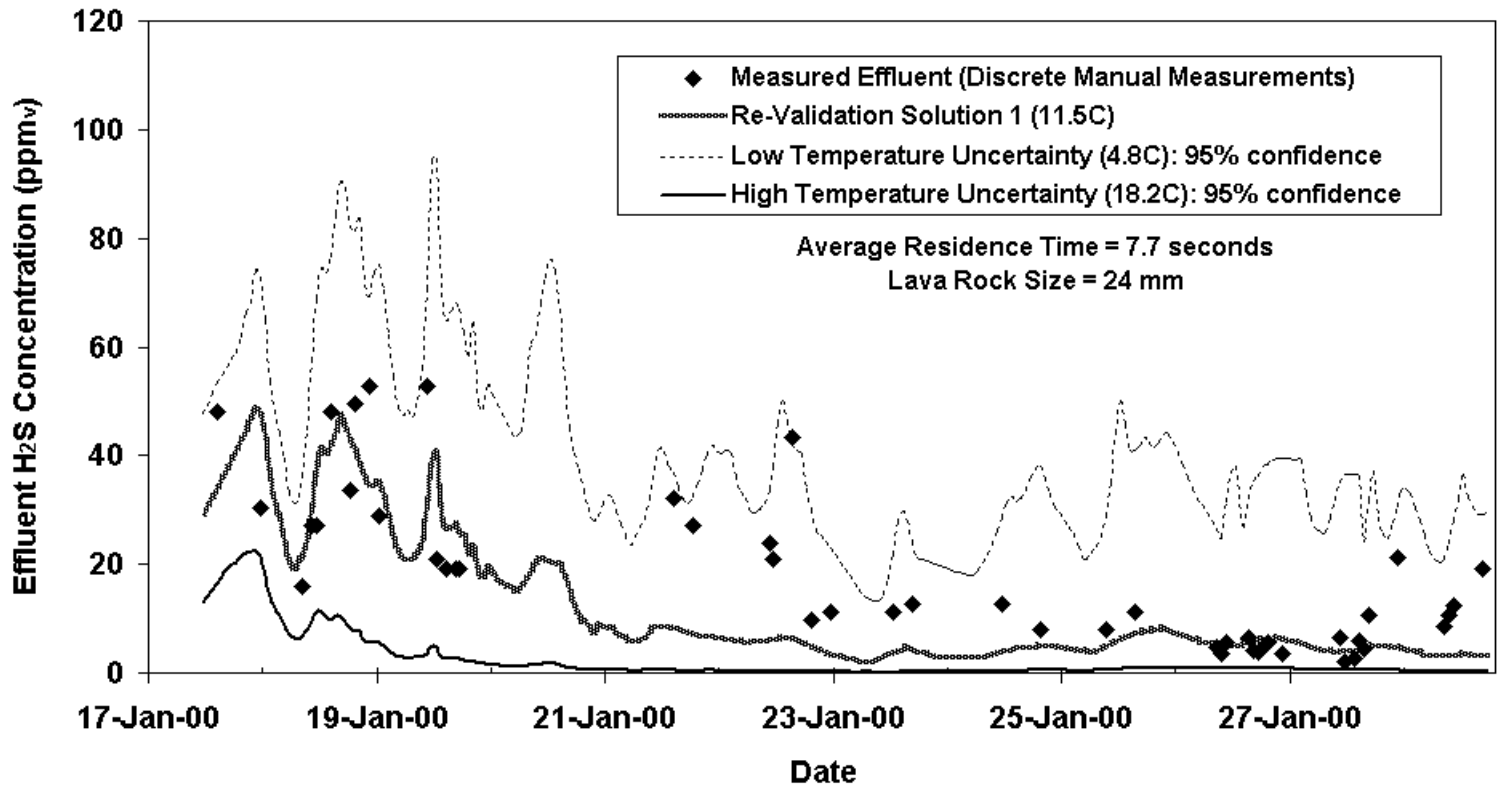

Figure B.3 Model Simulated Effluent $\mathrm{H}_{2} \mathrm{~S}$ Concentration for Solution 1 Re-validation Showing Temperature Uncertainty Approximation. 


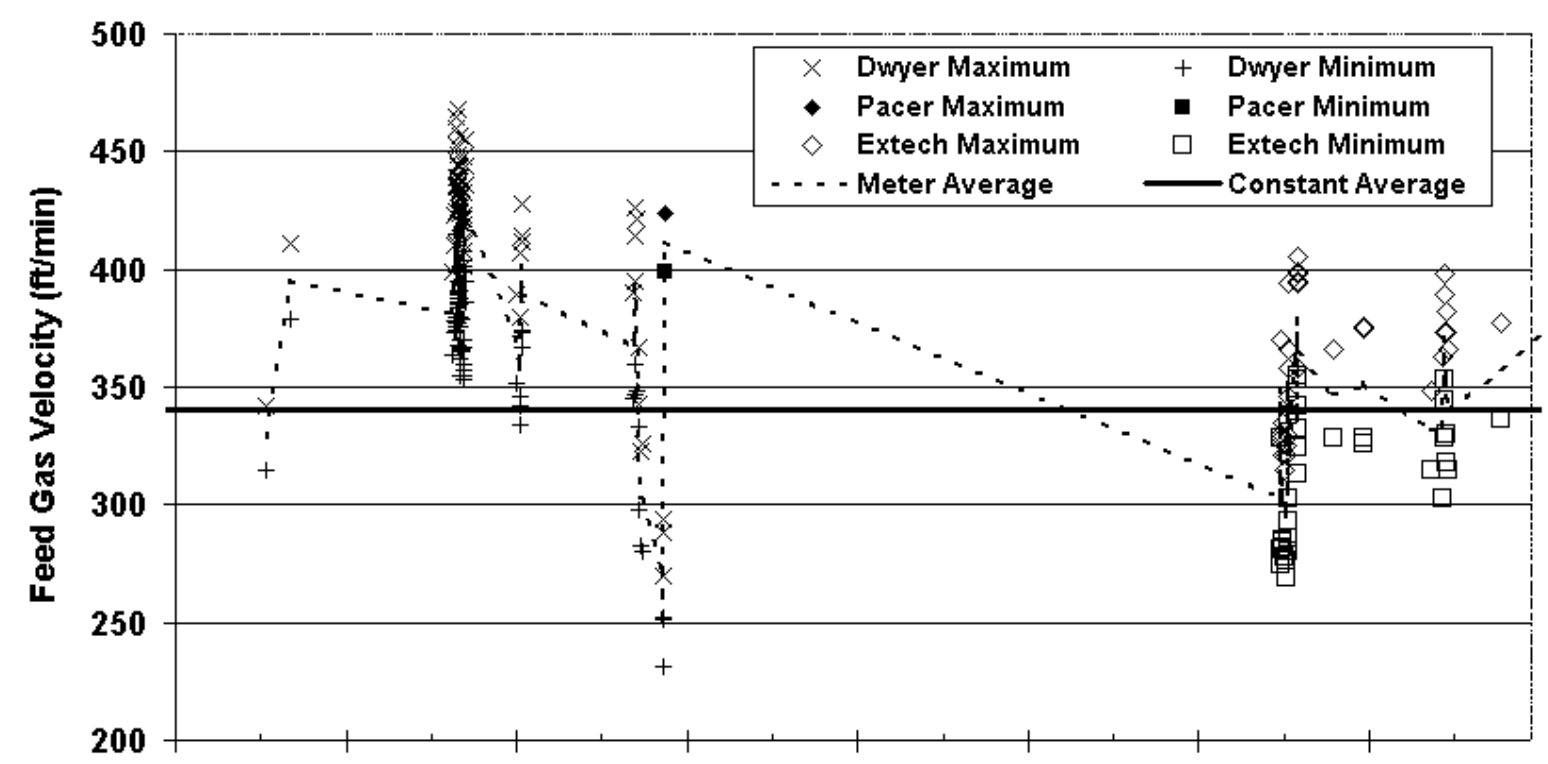

07-Mar-00 08-Mar-00 09-Mar-00 10-Mar-00 11-Mar-00 12-Mar-00 13-Mar-00 14-Mar-00

Date

Figure B.4 Minimum and Maximum Air Feed Velocity as a Function of Time During Calibration Period for Various Anemometers.

Figure B.5 shows the model simulated effluent $\mathrm{H}_{2} \mathrm{~S}$ concentration for the Solution 1 recalibration with the uncertainty approximation due to flow. The upper $95 \%$ confidence limit of flow was $2.5 \mathrm{~m}^{3} / \min \left(88 \mathrm{ft}^{3} / \mathrm{min}\right)$ and the lower limit was $1.6 \mathrm{~m}^{3} / \mathrm{min}\left(57 \mathrm{ft}^{3} / \mathrm{min}\right)$. Compared to Solution 1, the model-simulated effluent $\mathrm{H}_{2} \mathrm{~S}$ concentration is much lower using the lower $95 \%$ confidence limit of flow during the influent spike at the beginning of the calibration period but is only slightly lower at the end of the calibration period. Conversely, the model-simulated effluent $\mathrm{H}_{2} \mathrm{~S}$ concentration is much about the same using the upper $95 \%$ confidence limit of flow during the influent spike at the beginning of the calibration period but is much higher at the end of the calibration period when compared to Solution 1. During the influent $\mathrm{H}_{2} \mathrm{~S}$ concentration spike at the beginning of the calibration period, the maximum effluent $\mathrm{H}_{2} \mathrm{~S}$ concentration is $2.6 \mathrm{ppm}_{\mathrm{v}}$ for the variable flow compared to $2.4 \mathrm{ppm}_{\mathrm{v}}$ and $0.6 \mathrm{ppm}_{\mathrm{v}}$ using the upper $\left(2.5 \mathrm{~m}^{3} / \mathrm{min}\right)$ and lower 
(1.6 $\left.\mathrm{m}^{3} / \mathrm{min}\right) 95 \%$ confidence limits of flow, respectively. During the more stable influent $\mathrm{H}_{2} \mathrm{~S}$ concentration at the end of the calibration period, the minimum effluent $\mathrm{H}_{2} \mathrm{~S}$ concentration is 0.2 $\mathrm{ppm}_{\mathrm{v}}$ for variable flow compared to $0.5 \mathrm{ppm}_{\mathrm{v}}$ and $0.1 \mathrm{ppm}_{\mathrm{v}}$ using the upper $(2.5 \mathrm{~m} / \mathrm{min})$ and lower $\left(1.6 \mathrm{~m}^{3} / \mathrm{min}\right) 95 \%$ confidence limits of flow, respectively. Plots of Solution 2 and Solution 3 (determined in Appendix A) re-calibration uncertainty estimates are similar to Figure B.5 but the model simulated effluent $\mathrm{H}_{2} \mathrm{~S}$ concentration using the upper $95 \%$ confidence limit of flow for Solution 4 is significantly lower than for Solution 2 and Solution 3 (data not shown).

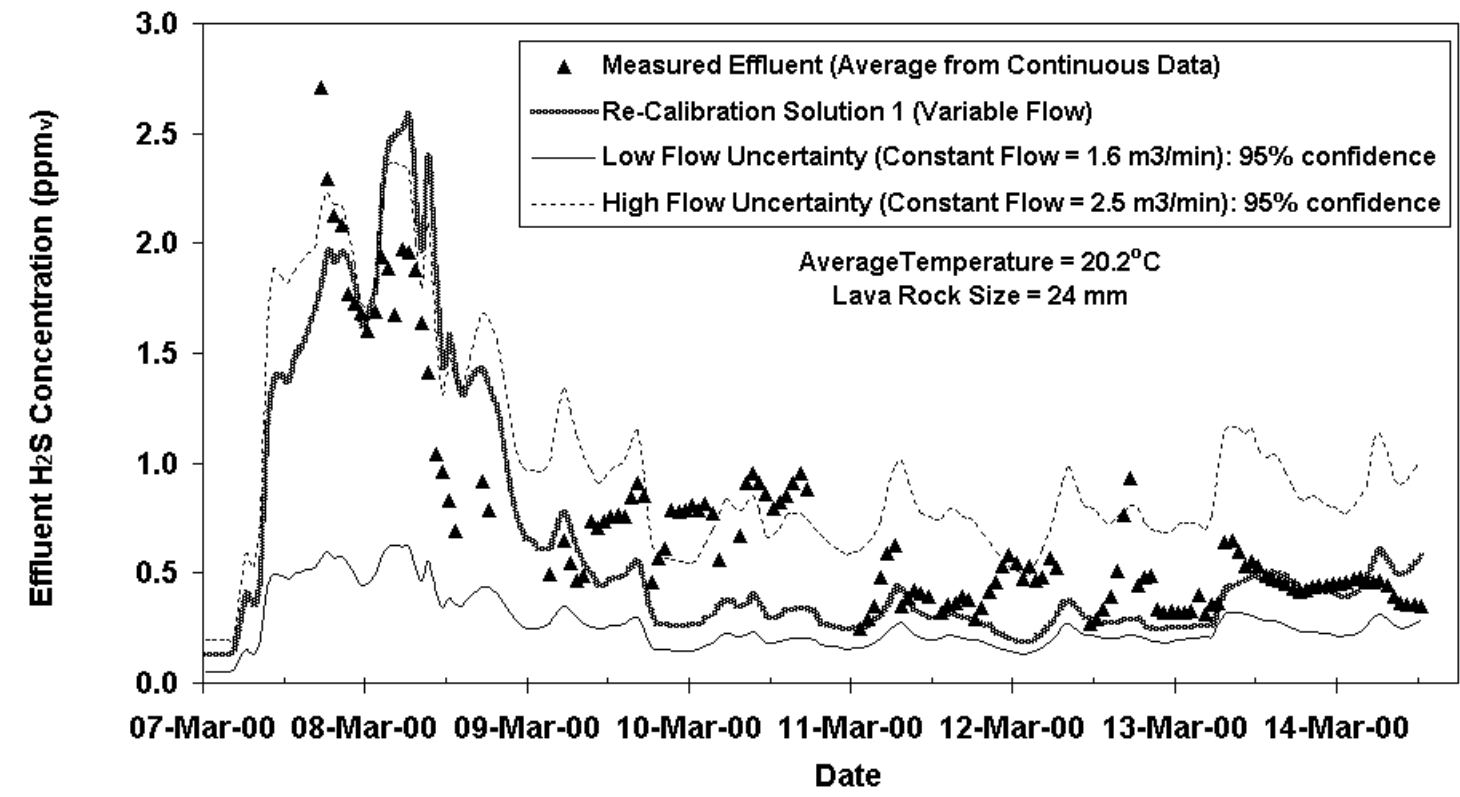

Figure B.5 Model Simulated Effluent $\mathrm{H}_{2} \mathrm{~S}$ Concentration for Solution 1 Re-calibration Showing Flow Uncertainty Approximation.

Figure B.6 shows the model simulated effluent $\mathrm{H}_{2} \mathrm{~S}$ concentration for the Solution 1 revalidation with the estimated uncertainty due to flow. The upper $95 \%$ confidence limit of flow was $2.1 \mathrm{~m}^{3} / \mathrm{min}\left(74 \mathrm{ft}^{3} / \mathrm{min}\right)$ and lower limit was $1.0 \mathrm{~m}^{3} / \min \left(35 \mathrm{ft}^{3} / \mathrm{min}\right)$. Compared to the Solution 1 re-validation, the model-simulated effluent $\mathrm{H}_{2} \mathrm{~S}$ concentration is slightly higher using the upper $95 \%$ confidence limit of flow and much lower using the lower $95 \%$ confidence limit of 
flow. During the initial start-up period, the maximum effluent $\mathrm{H}_{2} \mathrm{~S}$ concentration is $49 \mathrm{ppm}_{\mathrm{v}}$ for variable flow compared to $62 \mathrm{ppm}_{\mathrm{v}}$ and $23 \mathrm{ppm}_{\mathrm{v}}$ using the upper $\left(2.1 \mathrm{~m}^{3} / \mathrm{min}\right)$ and lower $(1.0$ $\mathrm{m}^{3} / \mathrm{min}$ ) $95 \%$ confidence limits of flow, respectively. Plots of Solution 2, Solution 3, and Solution 4 (determined in Appendix A) re-validation with the flow uncertainty are similar to those in Figure B.6 (data not shown).

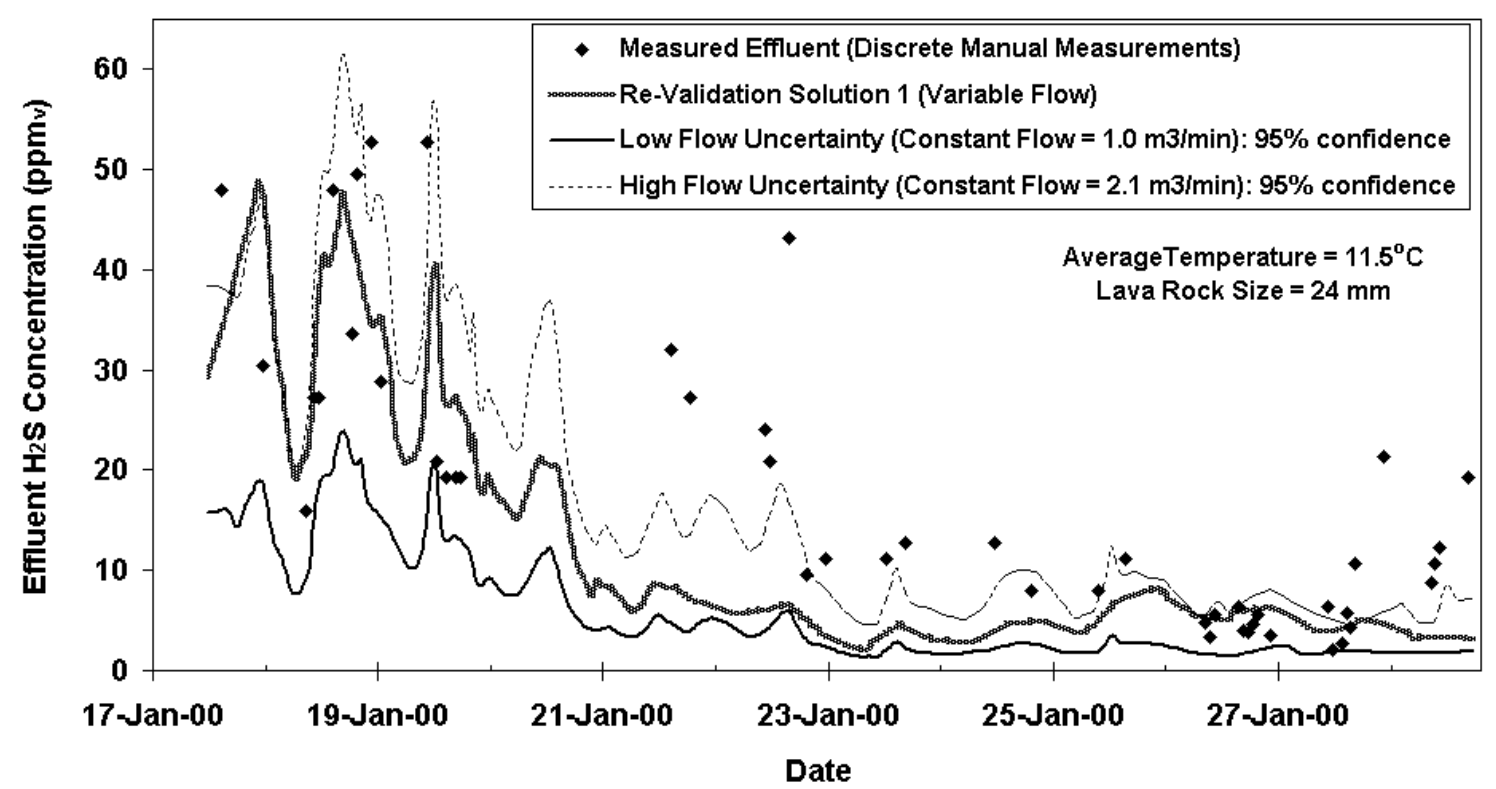

Figure B.6 Model Simulated Effluent $\mathrm{H}_{2} \mathrm{~S}$ Concentration for Solution 1 Re-validation Showing Flow Uncertainty Estimate.

It is useful to examine the effect of uncertainty due to all of the various model input parameters on the actual model output. If the uncertainty due to some input parameter is small relative to others, it can often be neglected. While there is uncertainty in the temperature and flow measurements, there is also a uncertainty in determining the following model parameters from the model solution: biofilm diffusivity $\left(\mathrm{D}_{\mathrm{b}}\right)$, sphericity $(\phi)$, cell yield $(\mathrm{Y})$, half saturation constant $\left(\mathrm{K}_{\mathrm{s}}\right)$, maximum specific growth rate $\left(\mu_{\max }\right)$, minimum biofilm concentration $\left(\mathrm{C}_{\mathrm{x} \text { min }}\right)$, 
maximum biofilm concentration $\left(\mathrm{C}_{\mathrm{xmax}}\right)$, and initial biofilm concentration $\left(\mathrm{C}_{\mathrm{xo}}\right)$. These model parameters were determined by trial and error to obtain the best possible solutions based on minimizing the objective function and the sum of absolute value of the residuals. The original solution (determined in Chapter 4) and the four additional solutions (determined in Appendix A) indicate that the values for these model input parameters may encompass a large range of values and therefore, have uncertainty as well. Even more potential solutions encompassing a larger input parameter range than those determined in Appendix A may also be possible. However, the uncertainty of any single input parameter based on this range is too large to be useful in determining the uncertainty in the model simulated effluent $\mathrm{H}_{2} \mathrm{~S}$ concentration. Figure A.3 and Figure A.4 illustrate the uncertainty in the model simulated effluent $\mathrm{H}_{2} \mathrm{~S}$ concentrations based on the four different re-calibration and re-validation solutions (determined in Appendix A), respectively.

In Figure 4.6 in Chapter 4, the combination of values for $\mathrm{K}_{\mathrm{s}}$ and $\mu_{\max }$ from Solution 1 (see Appendix A) are used to determine the values of $\mathrm{S}_{\min }$ as a function of temperature. The plot in Figure 4.6 applies for that specific solution: Solution 1; however, three more possible solutions are provided in Appendix A. Figure C.5 in Appendix C shows the plot of the theoretical minimum as a function of temperature for all four re-calibration solutions (that were determined in Appendix A) as well as the original solution from Martin et al. (2002). The combinations of $\mathrm{K}_{\mathrm{s}}$ and $\mu_{\max }$ for the three additional solutions from Appendix $\mathrm{A}$ are used to estimate the uncertainty in $S_{\min }$ : Solution 3 is used to calculate the lower uncertainty of $S_{\min }$ and Solution 4 is used to calculate the upper uncertainty of $S_{\min }$ in Figure 4.6. Additionally, a $20 \%$ uncertainty in the decay coefficient $\left(\mathrm{k}_{\mathrm{d}}\right)$ was assumed in calculating the uncertainty shown in Figure 4.6. 
In Figure A.5 (see Appendix A) there is uncertainty in the $\mathrm{H}_{2} \mathrm{~S}$ concentration measured at various locations through the depth of the biofilter bed between the influent and effluent. The values for the actual measured data shown in Figure A.5 are averages from seven manual depth concentration measurements made from Mach 12, 2000 through Mach 14, 2000. At the high $\mathrm{H}_{2} \mathrm{~S}$ concentrations (near the influent), the error bars represent the $95 \%$ confidence limits. However, the digital readout of the Conspec meter used to measure the $\mathrm{H}_{2} \mathrm{~S}$ concentration showed only the whole number value (zero significant digits). Thus, at low $\mathrm{H}_{2} \mathrm{~S}$ concentrations (greater than $40 \mathrm{~cm}$ from the influent), the uncertainty of the Conspec meter is included in error bars. 


\section{APPENDIX C \\ COMPARISON OF VARIOUS BIOFILTER DESIGN AND PERFORMANCE CHARACTERIZATION PLOTS}

In Chapter 4, the Solution 1 parameters (determined in Appendix A) were used as model input for the design and characterization evaluation. However, in addition to Solution 1, three more possible solutions are determined in Appendix A as well as the original solution from Chapter 3. The plots shown in the figures in this Appendix are for those four additional solutions (determined in Appendix A and in Chapter 3). Table A.3 lists the parameters for the original solution and Table A.5 lists the parameters for Solutions 1, 2, 3, and 4 in Appendix A.

The plots in this Appendix correspond to plots from Chapter 4 as summarized in Table C.1. For a more detailed explanation of the plots in this Appendix, refer to the corresponding plots and descriptions in Chapter 4. Each point in the first four figures (Figures C.1, C.2, C.3, and C.4) in this Appendix represents the effluent $\mathrm{H}_{2} \mathrm{~S}$ concentration obtained from a single model simulation run for 365 days.

The conditions in the first four figures (Figures C.1, C.2, C.3, and C.4) in this Appendix are as follows: $20 \mathrm{ppm}_{\mathrm{v}}$ influent $\mathrm{H}_{2} \mathrm{~S}$ concentration, $283 \mathrm{~m}^{3} / \mathrm{sec}$ flow, $1.8 \mathrm{~m}$ bed depth, $24 \mathrm{~mm}$ size lava rock, and $17^{\circ} \mathrm{C}$ bed temperature. In the fifth figure, Figure C.5, values of the steadystate theoretical minimum effluent $\mathrm{H}_{2} \mathrm{~S}$ concentration were determined at various temperatures and the values depend only on the physical and biochemical parameters defined in Equation 4.8 of Chapter 4.

Plots for the Solution 1 parameters are not shown in the first four figures (Figures C.1, C.2, C.3, and C.4) in this Appendix because they are nearly identical to the plots for the Solution 
3 parameters; also, the plots using Solution 1 parameters are already provided in the figures in Chapter 4. Although plots for the Solution 1 parameters are not included in the figures in this Appendix, they are included in the discussion. For reference, they are approximately the same as the plots for the Solution 3 parameters.

Table C.1: Appendix C Plots and Corresponding Plots in Chapter 4.

\begin{tabular}{|c|c|c|}
\hline Plot Description & Chapter 4 Figure & Appendix C Figure \\
\hline Loading vs. Elimination & Figure 4.1 & Figure C.1 \\
\hline Loading vs. \% Removal & Figure 4.3 & Figure C.2 \\
\hline Residence Time vs. \% Removal & Figure 4.4 & Figure C.3 \\
\hline Residence Time vs. Concentration & Figure 4.5 & Figure C.4 \\
\hline Temperature vs. Theoretical Minimum & Figure 4.6 & Figure C.5 \\
\hline
\end{tabular}

Figure C.1 shows the model simulated plots of elimination capacity as a function of loading for the three re-calibration solutions (Solutions 2, 3, and 4, determined in Appendix A) as well as the original solution (determined in Chapter 3). The $\mathrm{EC}_{\max }$ is approximately $95 \mathrm{~g}$ $\mathrm{S} / \mathrm{m}^{3}-\mathrm{hr}$ for Solution 4, compared to approximately $50 \mathrm{~g}-\mathrm{S} / \mathrm{m}^{3}-\mathrm{hr}$ for Solutions 1,2 , and 3, and approximately $30 \mathrm{~g}-\mathrm{S} / \mathrm{m}^{3}-\mathrm{hr}$ for the original solution.

Figure C.2 shows the model simulated plots of removal efficiency as a function of loading for the re-calibration solutions (Solutions 2, 3, and 4, determined in Appendix A) and the original solution (determined in Chapter 3). The plot for the original solution shows the greatest decrease in removal efficiency with increasing loading while the plot for Solution 4 shows the smallest decrease in removal efficiency with increasing loading. Also, the plot for the original solution approaches a removal efficiency of greater than $99 \%$ while the plots for the other solutions (Solutions 1, 2, 3, and 4) approach a removal efficiency of 95\% to $97 \%$. 


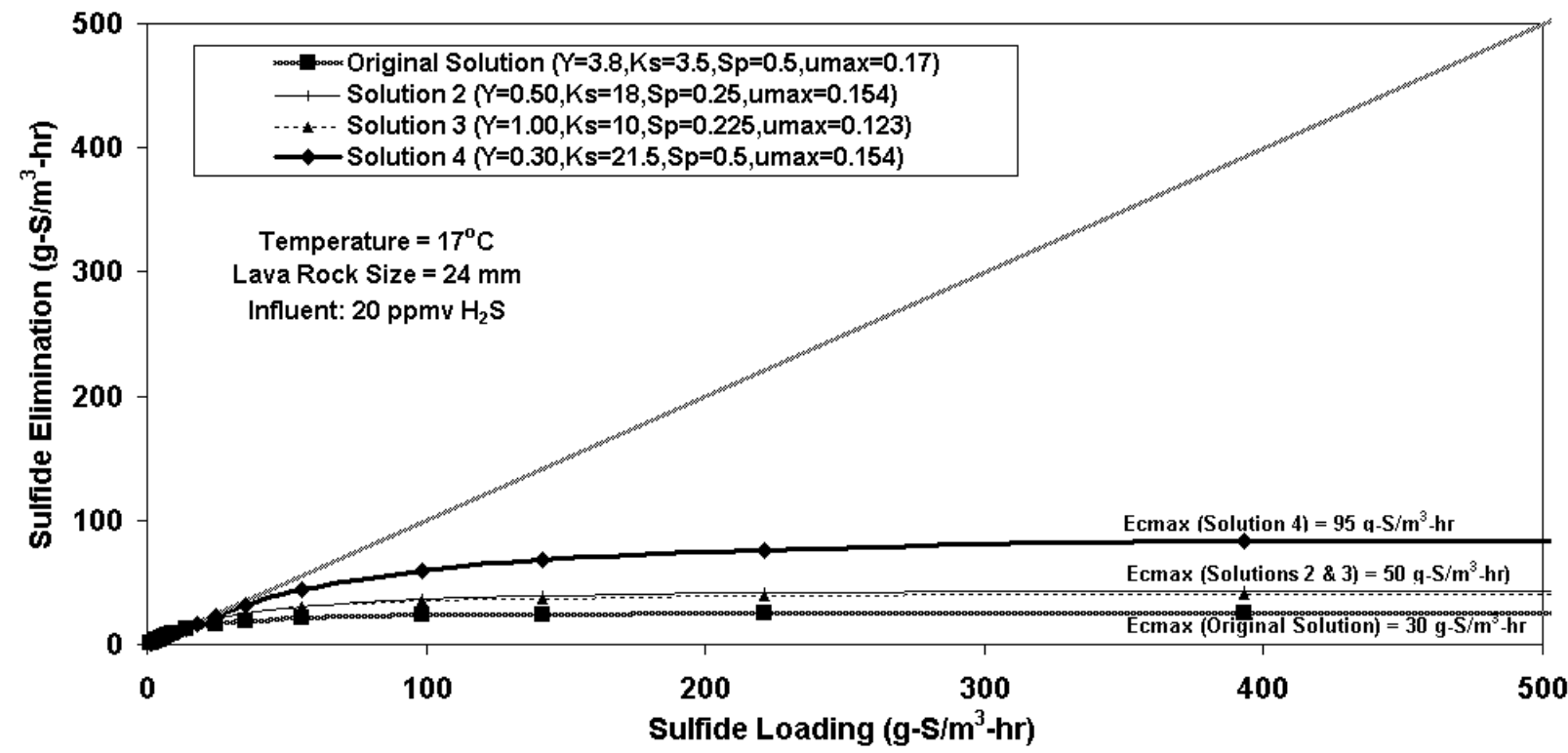

Figure C.1: Model Simulated Sulfide Elimination as a Function of Sulfide Loading for Various Model Input Parameters.

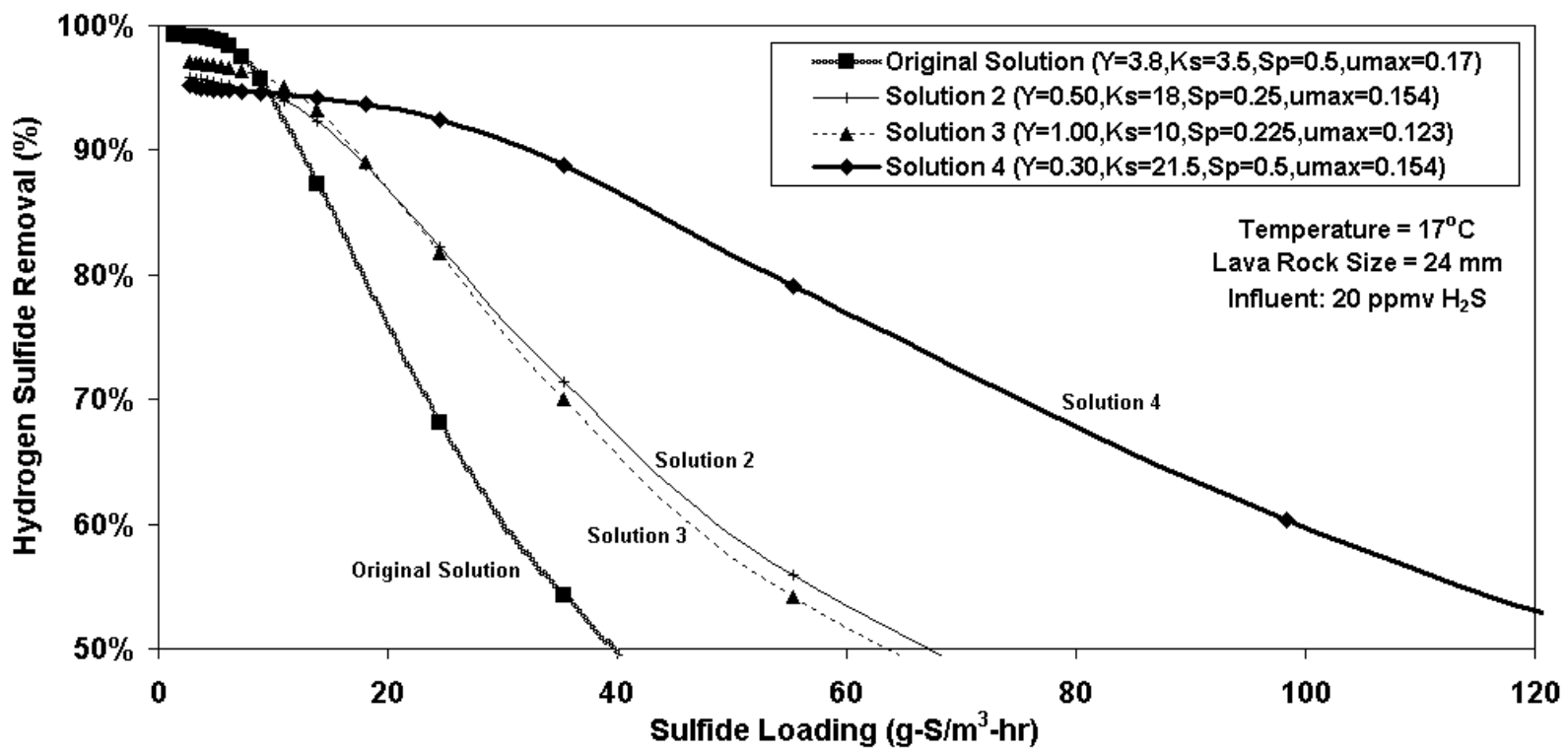

Figure C.2: Model Simulated Hydrogen Sulfide Removal as a Function of Sulfide Loading for Various Model Input Parameters. 
Figure C.3 shows the model simulated plots of removal efficiency as a function of residence time for the re-calibration solutions (Solutions 2, 3, and 4, determined in Appendix A) and the original solution (determined in Chapter 3). The original solution approaches a removal efficiency of greater than 99\%, while Solutions 1 and 3 approach a removal efficiency of approximately $97 \%$, and Solutions 2 and 4 approach a removal efficiency of approximately 95\%. A residence time of approximately 3 seconds is required to approach the maximum removal efficiency for Solution 4 compared to approximately 4 seconds for Solutions 1, 2, and 3 and approximately 6 seconds for the original solution.

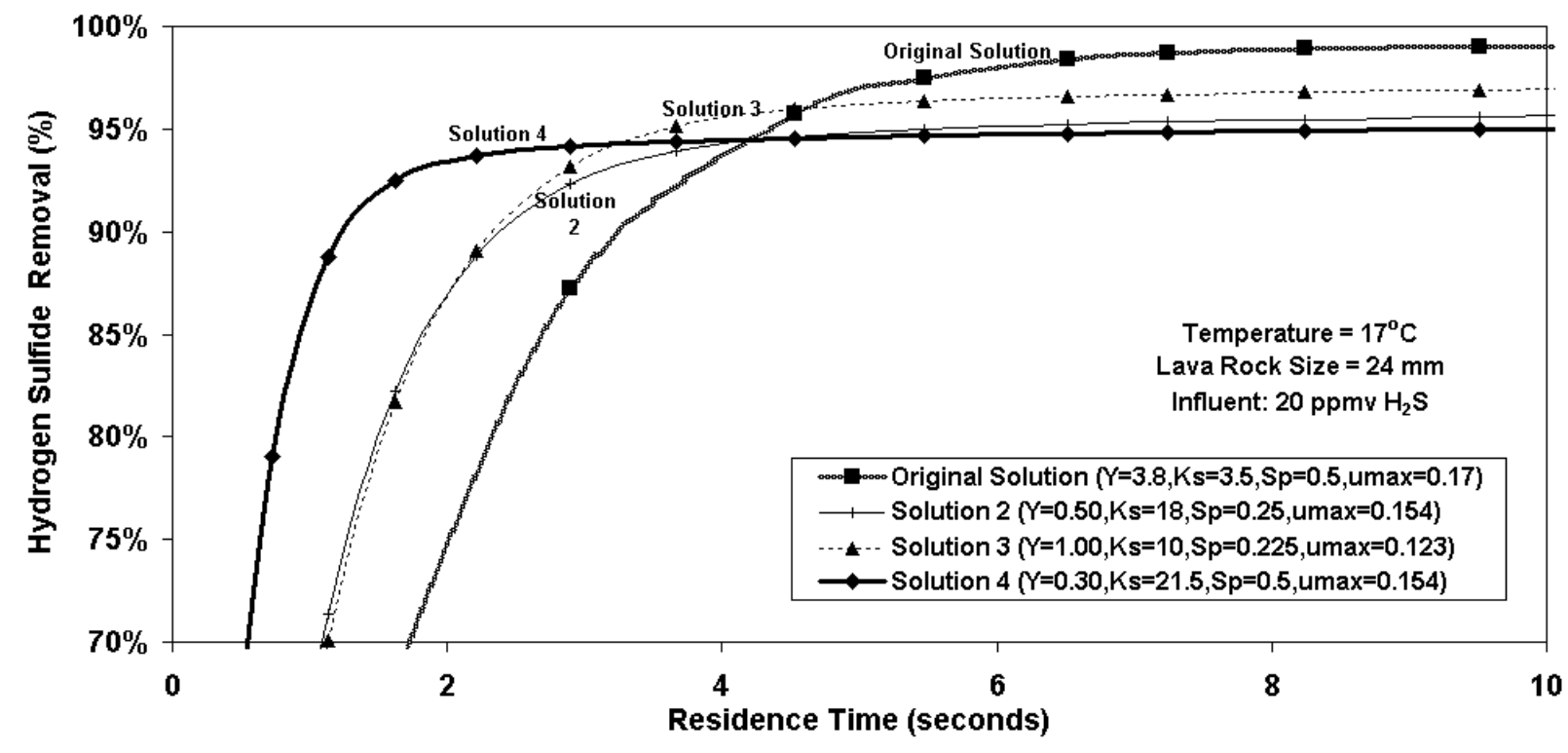

Figure C.3: Model Simulated Hydrogen Sulfide Removal as a Function of Residence Time for Various Model Input Parameters.

Figure C. 4 shows the model simulated plots of effluent $\mathrm{H}_{2} \mathrm{~S}$ concentration as a function of residence time for the re-calibration solutions (Solutions 2, 3, and 4, determined in Appendix A) and the original solution (determined in Chapter 3). A residence time of approximately 6 
seconds is required to approach the minimum effluent $\mathrm{H}_{2} \mathrm{~S}$ concentration of approximately 200 $\mathrm{ppb}_{\mathrm{v}}$ for the original solution compared to approximately 3 seconds required to approach the minimum effluent $\mathrm{H}_{2} \mathrm{~S}$ concentration of approximately $1,000 \mathrm{ppb}_{\mathrm{v}}$ for Solution 4 .

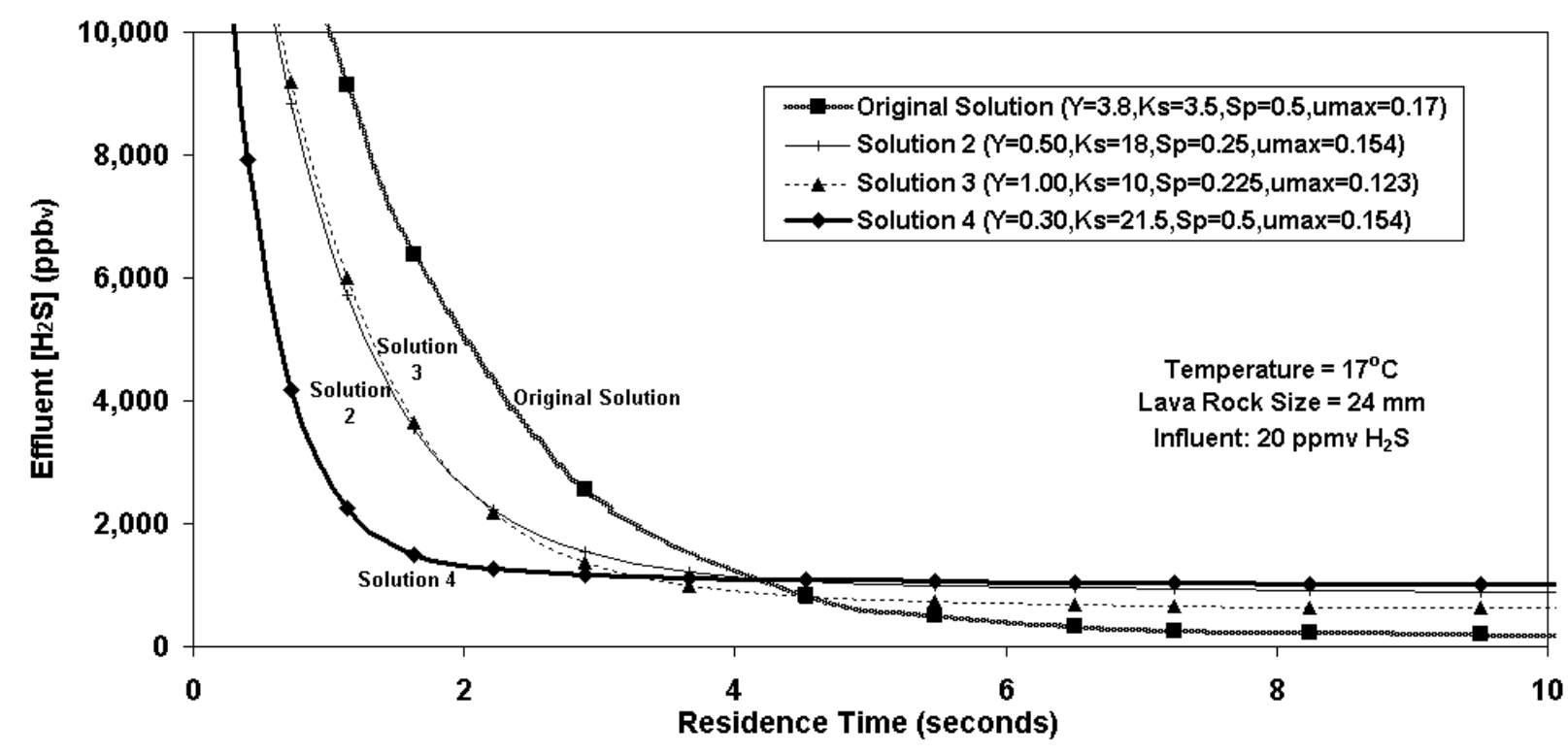

Figure C.4: Model Simulated Effluent Hydrogen Sulfide Concentration as a Function of Residence Time for Various Model Input Parameters.

Figure C.5 shows a plot of the steady-state theoretical minimum $\mathrm{H}_{2} \mathrm{~S}$ concentration $\left(\mathrm{S}_{\min }\right)$ as a function of temperature for all four re-calibration solutions (determined in Appendix A) as well as the original solution from Martin et al. (2002). $S_{\min }$ decreases exponentially with increasing temperature and the slope is the same for each solution. However, at a given temperature, $S_{\min }$ for the original solution (determined in Chapter 3 ) is much lower than for the four re-calibration solutions (determined in Appendix A). 


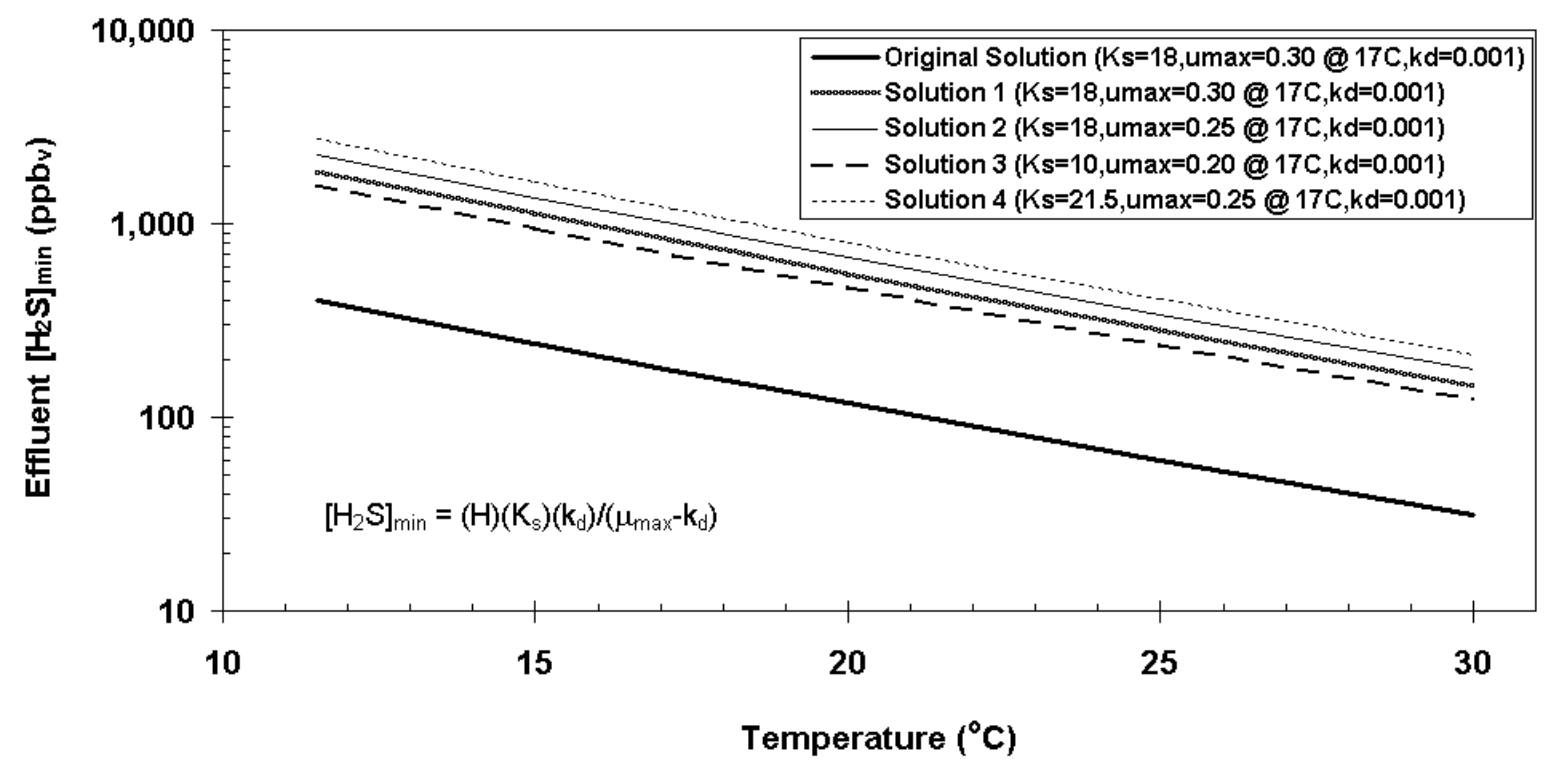

Figure C.5: Theoretical Minimum Steady-state Effluent Hydrogen Sulfide Concentration as a Function of Temperature for Various Model Input Parameters. 